\author{
Universidade de São Paulo \\ Faculdade de Saúde Pública
}

\title{
Requalificação de área contaminada por resíduos: experiências internacionais e dois casos do município de São Paulo
}

Camila Vitorino dos Santos

Dissertação apresentada ao Programa de PósGraduação em Saúde Pública para obtenção do título de Mestre em Ciências.

Área de Concentração: Saúde ambiental, modos de vida e sustentabilidade

Orientadora: Prof. Dra. Helena Ribeiro 


\section{Requalificação de área contaminada por resíduos: experiências internacionais e dois casos do município de São Paulo}

Camila Vitorino dos Santos

Dissertação apresentada ao Programa de PósGraduação em Saúde Pública da Faculdade de Saúde Pública da Universidade de São Paulo para obtenção do título de Mestre em Ciências.

Área de Concentração: Saúde ambiental, modos de vida e sustentabilidade

Orientadora: Prof. Dra. Helena Ribeiro

\section{Versão Original}

São Paulo

2020 
Autorizo a reprodução e divulgação total ou parcial deste trabalho, por qualquer meio convencional ou eletrônico, para fins de estudo e pesquisa, desde que citada a fonte.

Santos, Camila Vitorino

Requalificação de área contaminada por resíduos:

experiências internacionais e dois casos do municipio de

São Paulo / Camila Vitorino Santos; orientadora Helena

Ribeiro. -- São Paulo, 2020.

$177 \mathrm{p}$.

Dissertação (Mestrado) -- Faculdade de Saúde Pública da Universidade de São Paulo, 2020.

1. área contaminada por resíduo. 2. requalificação. 3 . parque urbano. 4. saúde ambiental. 5. qualidade de vida. I. Ribeiro, Helena, orient. II. Título. 
Dedico ao meu avô Pedro Vitorino (in memória). 


\section{AGRADECIMENTOS}

Agradeço primeiramente à Deus por estar presente em minha vida.

À minha família, em especial a minha mãe Maria Vitorino e tia Maria José, pelo incentivo e compreensão que me deu forças para iniciar e terminar essa jornada.

À minha orientadora Helena Ribeiro, pela confiança que depositou no meu trabalho, pela oportunidade deste aprendizado, por me impulsionar a vivenciar novos desafios e por toda a valiosa contribuição nesta dissertação.

Aos professores Arlindo Philippi Jr e Ednilson Viana, pelas sugestões enriquecedoras e boas conversas durante a elaboração deste trabalho.

Aos meus colegas do Grupo Técnico de Áreas Contaminadas (GTAC) da SVMA, em especial à Márcia Lozano, Danilo Dias, Elaine Cardoso, Rosimeire Lobato e Maykon Ivan Palma pelas informações, dicas e auxílio na obtenção dos dados fundamentais a esta pesquisa.

À minha amiga Carolina Afonso Pinto pela amizade formada por toda a vida, apoio, valiosas contribuições e por sempre me impulsionar a enxergar novas perspectivas diante dos obstáculos.

À Arquiteta Ana Lucia Pinto de Faria Burjato da Secretaria de Infraestrutura de Meio Ambiente (SIMA) do Estado de São Paulo, pela contribuição na obtenção dos dados do Parque Estadual Villa-Lobos.

À Arquiteta e Prof $f^{a}$ Patrícia Mara Sanches da ESALQ/USP pela indicação das referências bibliográficas essenciais para a construção deste trabalho.

À Técnica Maria José da CETESB-Tatuapé pelas contribuições no decorrer dos agendamentos das visitas.

Aos meus colegas do mestrado Marília Campos e João Assis da Faculdade de Saúde Pública, por todas contribuições e pelos momentos de dificuldade e superação que passamos juntos.

As minhas amigas Andreia Matos, Daiane Notari, Elaine Cristina, Jessica de Paula e Pamela Cristina pela força e apoio em todas minhas decisões e por estarem sempre presentes em minha vida, tornando meus dias mais leves. 
"Sem a natureza não existimos mais, ela é a base da nossa vida"

Ana Primavesi 


\section{RESUMO}

SANTOS, C. V. Requalificação de área contaminada por resíduos: experiências internacionais e dois casos do município de São Paulo. 2020. 180p. Dissertação (Mestrado em Ciências) - Faculdade de Saúde Pública, Universidade de São Paulo. São Paulo, 2020.

Áreas contaminadas por resíduos vêm sendo reutilizadas e requalificadas ambientalmente em todo o mundo, com a finalidade de reintegrá-las à dinâmica urbana com novas funções como parques públicos. Essa prática vem despertando a atenção dos órgãos de saúde pública e de controle ambiental, em função dos riscos que podem ocasionar à saúde humana e ao meio ambiente, e também pelo seu grande potencial de reutilização. Tendo em vista a crescente ocorrência da expansão urbana desordenada e a escassez de áreas livres e espaços vagos para novos usos como áreas verdes e de lazer. O presente trabalho objetivou estudar processos de requalificação de áreas contaminadas por resíduos para transformação em parques, tendo como estudo dois casos de parques localizados no município de São Paulo e experiências internacionais. A metodologia foi baseada em revisão bibliográfica e pesquisa documental. O levantamento nas bases bibliográficas Dedalus e Web of Science buscou encontrar estudos publicados, nos últimos 20 anos sobre áreas contaminadas por resíduos e sua revitalização em parques. A pesquisa documental foi realizada nas instituições da SVMA, SIMA e CETESB. Foram identificados casos bem-sucedidos no contexto internacional de conversão em áreas verdes com o apoio de fundos nacionais para áreas contaminadas órfãs, lista de áreas contaminadas prioritárias, criação de impostos, apoio financeiro, parceria entre os órgãos competentes e flexibilização da legislação voltada à proteção do solo e outros. No Brasil essa experiência ainda é muito tímida e lenta, em função dos problemas atrelados à falta de recursos e incentivos fiscais. De acordo com os resultados obtidos, o processo de requalificação dos dois casos selecionados foi desigual, com destaque para três aspectos: os atores envolvidos no caso, o papel da sociedade civil e a Ação do Ministério Público do Estado de São Paulo. Desta forma, evidencia-se que casos de sucesso de áreas contaminadas por resíduos no Município de São Paulo estão vinculado ao apoio direto desses aspectos complementado com a iniciativa privada. Além disso, se faz necessário um consenso entre o poder público quanto as legislações vigentes de áreas contaminadas versus reparação integral do dano ambiental, para que não interfira diretamente no processo de tomada de decisão dos projetos urbanísticos de requalificação de áreas contaminadas para transformação em parques.

Palavras-chave: área contaminada por resíduos, requalificação, parque urbano, saúde ambiental, qualidade de vida. 


\begin{abstract}
ABSTRAC
SANTOS, C. V. Requalification of an area contaminated by waste: international experiences and two cases in the municipality of São Paulo. 180p. Dissertation (Master's degree Science) - School of Public Health, University of São Paulo. São Paulo, 2020.

Currently, areas contaminated by waste have been reused and environmentally upgraded worldwide, to reintegrate them into urban dynamics with new functions such as public parks. For this reason, such environmental actions and practices have attracted the attention of public health and environmental control agencies, due to the risks that these can cause to human health and the environment, and also due to their great potential for reuse. Therefore, the growing and disordered urban expansion brings the scarcity of free areas and vacant spaces for green and leisure areas or new utilities. This master's thesis presented here aims to study the processes of requalification of areas contaminated by waste to transform them into parks, having as basis for the study two cases of parks located in the city of São Paulo and also experiences and international models. The methodology was based on literature review and documentary research. The survey in the bibliographic databases Dedalus and Web of Science sought to find studies published in the last 20 years, on areas contaminated by waste and its revitalization and transformation into parks. The documentary research was carried out in the institutions of SVMA, SIMA and CETESB. Successful cases have been identified at the international level of conversion to green areas, with the support of national funds for orphaned contaminated areas, list of priority contaminated areas, tax creation, financial support, partnerships between institutions related to the area, greater flexibility in legislation focused on soil protection, among others. According to the results, the requalification process of the two selected cases was uneven, with emphasis on three aspects: the actors involved in the case study, the role of civil society and the action of the Public Ministry. Thus, it is evident that successful cases of areas contaminated by waste in the Municipality of São Paulo are linked to the direct support of these aspects complemented by the private initiative. In addition, there is a need for a consensus among the public authorities regarding the current legislation on contaminated areas versus full repair of environmental damage, so that it does not directly interfere in the decision-making process of urban projects for the rehabilitation of contaminated areas for transformation into parks.
\end{abstract}

Keywords: Contaminated area by waste, requalification of contaminated área, urban park, environmental health, quality of life. 


\section{LISTA DE ABREVIATURAS E SIGLAS}

\begin{tabular}{|c|c|}
\hline $\mathrm{AC}$ & Área Contaminada \\
\hline $\mathrm{ACI}$ & Área Contaminada sob Investigação \\
\hline $\mathrm{ACRe}$ & Área Contaminada em Processo de Remediação \\
\hline ACRi & Área Contaminada com Risco Confirmado \\
\hline $\mathrm{ACRu}$ & Contaminada em Processo de Reutilização \\
\hline AME & Área em Processo de Monitoramento para encerramento \\
\hline AMLURB & Autoridade Municipal de Limpeza Urbana de São Paulo \\
\hline AP & Área com Potencial de Contaminação \\
\hline AR & Área Reabilitada para Uso Declarado \\
\hline AS & Área com Suspeita de Contaminação \\
\hline ATSDR & The Agency for Toxic Substances and Disease Registry \\
\hline CERCLA & Comprehensive Environmental Response, Compensation, and Liability \\
\hline Act & \\
\hline CETESB & Companhia Ambiental do Estado de São Paulo \\
\hline CONAMA & Conselho Nacional de Meio Ambiente \\
\hline CPU & Coordenadoria de Parques Urbano \\
\hline DD & Decisão de Diretoria \\
\hline $\mathrm{EC}$ & European Commission \\
\hline FEBRAC & Fundo Estadual para Prevenção e Remediação de Áreas Contaminadas \\
\hline FEMA & Fundo Especial do Meio Ambiente e Desenvolvimento Sustentável \\
\hline FUNDURB & Fundo do Desenvolvimento Urbano \\
\hline GAC & Gerenciamento de Áreas Contaminadas \\
\hline GTAC & Grupo Técnico de Áreas Contaminadas \\
\hline IPTU & Imposto Predial e Territorial Urbano \\
\hline MP & Ministério Público \\
\hline MPSP & Ministério Público do Estado de São Paulo \\
\hline ONG & Organizações Não Governamentais \\
\hline PDE & Plano Diretor Estratégico \\
\hline PMSP & Prefeitura Municipal de São Paulo \\
\hline PNRS & Política Nacional dos Resíduos Sólidos \\
\hline RSU & Resíduos Sólidos Urbanos \\
\hline SIMA & Secretaria de Infraestrutura e Meio Ambiente do Estado de São Paulo \\
\hline SVMA & Secretaria Municipal do Verde e Meio Ambiente de São Paulo \\
\hline UE & União Europeia \\
\hline USEPA & United States Environmental Protection Agency \\
\hline
\end{tabular}




\section{LISTA DE TABELAS}

Tabela 1- Número de áreas contaminadas cadastradas em São Paulo, até 2019.

145

Tabela 2- Situação ambiental das áreas cadastradas em São Paulo, até 2019. 


\section{LISTA DE QUADROS}

Quadro 1- Definições de área contaminada no Estado de São Paulo................................. 29

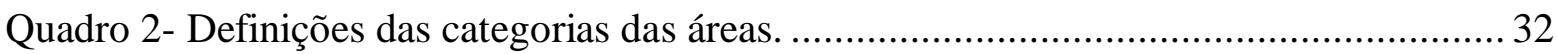

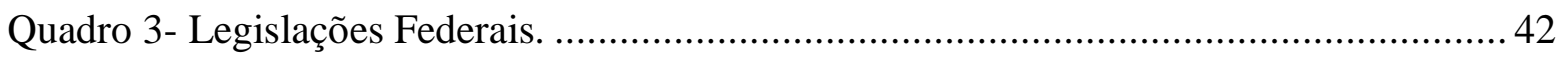

Quadro 4- Legislações Estaduais ....................................................................... 45

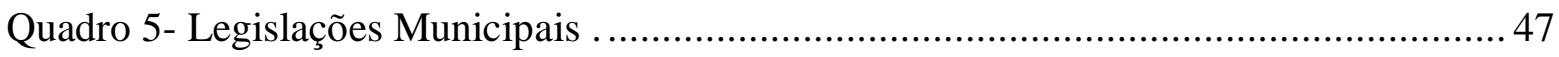

Quadro 6- Métodos de Disposição de Resíduos Sólidos no solo........................................ 61

Quadro 7- Legislações de Resíduos Sólidos Urbanos e Aterro Sanitários- Classe II. .......... 63

Quadro 8- Locais de Disposição de Resíduos no Município de São Paulo........................... 64

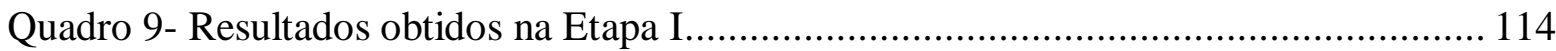

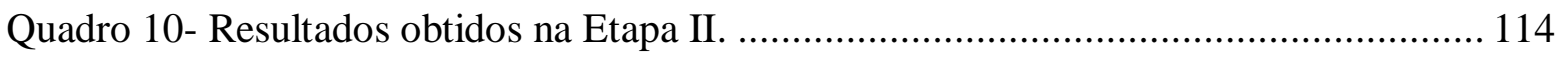

Quadro 11- Resultados da Avaliação de Risco à Saúde Humana .................................. 115

Quadro 12- Medidas Mitigadoras ara Reutilização da Área........................................... 115

Quadro 13- Risco identificado para saúde humana no parque........................................ 120

Quadro 14- Medidas do Plano de Intervenção para a área. ............................................ 120

Quadro 15- Resultados dos dados analíticos das amostras coletadas.............................. 132

Quadro 16- Medidas Mitigadoras para a área do Parque Estadual Villa-Lobos................. 133

Quadro 17- Resultados das amostras coletadas para Compostos Semi-Voláteis................ 135

Quadro 18-Riscos calculados e identificados à saúde humana para diferentes cenários. ... 137

Quadro 19-Medidas de Intervenção para Parque Estadual Villa-Lobos. .......................... 138

Quadro 20- Atrativos no Parque Estadual Villa-Lobos............................................... 140

Quadro 21- Histórico e Ações realizadas nas Áreas dos Estudos de Caso......................... 143

Quadro 22- Mecanismos essenciais de requalificação no contexto internacional. ............. 156 


\section{LISTA DE FIGURAS}

Figura 1- Métodos adotados para elaboração da pesquisa.............................................. 21

Figura 2- Localização da área de estudo- Parque Municipal Jardim Primavera................... 25

Figura 3- Localização da área de estudo Parque Estadual Villa-Lobos. ............................. 26

Figura 4- Principais fontes de contaminação do solo e água subterrânea. .......................... 27

Figura 5- Etapas do Gerenciamento de Áreas Contaminadas.......................................... 31

Figura 6- Área com indícios de contaminação............................................................. 33

Figura 7- Área com Suspeita de Contaminação. ............................................................. 34

Figura 8- Simulação Hipotética: cenário de exposição. .................................................... 35

Figura 9- Plano de Intervenção para Reutilização de Áreas Contaminadas. ........................ 37

Figura 10- Percentual: Nível Global- Disposição e Tratamento dos Resíduos Sólidos. ....... 50

Figura 11- Percentual- Métodos de Disposição Final e Destinação por Região................... 51

Figura 12- Principais fontes de contaminação do solo na Europa. .................................... 52

Figura 13- Taxas de reciclagem e recuperação de resíduos de embalagens na Europa. ....... 53

Figura 14- Percentual de tratamento dos resíduos de embalagens por país.........................54

Figura 15- Destinação dos RSU nos Estados Unidos..................................................... 55

Figura 16- Tratamento dos RSU no Mundo...................................................................... 56

Figura 17- Descarte de resíduos em via pública- Município de São Paulo. ........................ 59

Figura 18- Esquema de Aterro Sanitário de Resíduos Sólidos Urbanos. ........................... 62

Figura 19- Barão de Mauá: local aterrado com os resíduos............................................ 68

Figura 20- Vista do deslizamento no Morro do Bumba, Niterói-RJ, em abril de 2010....... 71

Figura 21 - Aterro Sanitário Brick Town: Vista do painel solar. ..................................... 80

Figura 22- Antigo aterro sanitário e a montanha de resíduos Hiriya................................. 81

Figura 23- Rio Ayalon e o Parque Ariel Sharon. ............................................................. 82

Figura 24- Empresas Petrolíferas e o Parque das Nações.............................................. 83

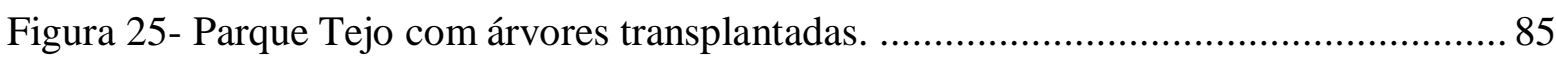

Figura 26- Aterro Freskills antes da implantação e após em operação. ................................ 86

Figura 27- Aterro Freshkills no ano de fechamento em 2001....................................... 87

Figura 28- Montes Sul e Norte do Aterro FreshKills, fechado em 1997........................... 87

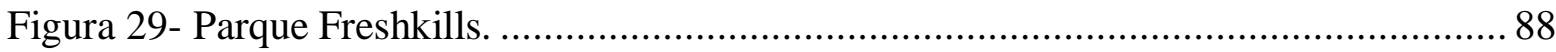

Figura 30- Ilha Pulau Semaku e a barcaça transportando os resíduos. .............................. 88

Figura 31 - Parque Chambers Gully-Austrália............................................................ 90 
Figura 32- Área antes da revitalização e o Parque Qiaoyuan. ......................................... 90

Figura 33- Disposição de resíduos na área, antes da construção do Parque Qiaoyuan. ........ 91

Figura 34- Plataformas de pallets e as cavidades secas do parque.................................. 92

Figura 35- Resíduos depositados na área do Aterro de Bowers...................................... 93

Figura 36- Área de Wetland adaptada para recreação .................................................... 94

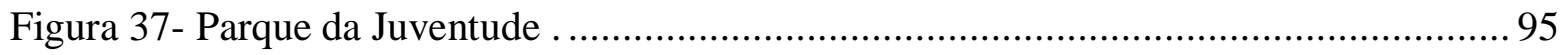

Figura 38- Parque da Juventude e a Estação Carandiru do Metrô. ..................................... 96

Figura 39- Áreas do Parque da Juventude em São Paulo. .............................................. 97

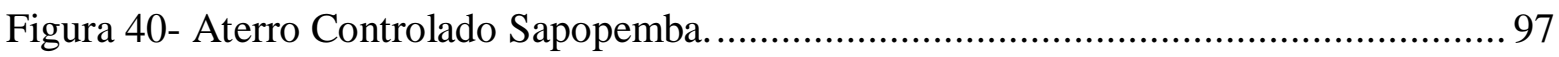

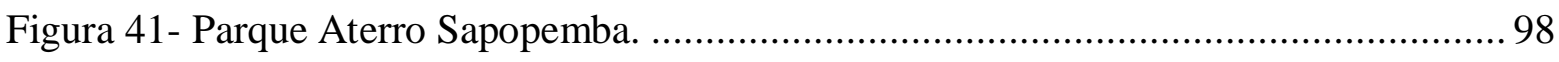

Figura 42- Lixão Sambaiatuba em São Vicente e Parque Ambiental Sambaiatuba.............. 99

Figura 43- Ações implantadas para a requalificação da área em parque............................ 99

Figura 44- Áreas esportivas, viveiros de mudas e compostagem do parque. ..................... 100

Figura 45- Localização Parque Municipal Jardim Primavera........................................... 105

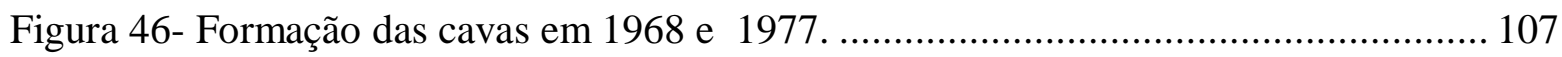

Figura 47- Estrutura do projeto elaborado do Aterro Sanitário do Jacuí, em 1983. ........... 108

Figura 48- Aterro controlado com a instalação dos drenos. .......................................... 109

Figura 49- Aterramento das cavas (1988) e cobertura com eucaliptos em 1993.............. 109

Figura 50- Residência que ocorreu a explosão em 1988. ................................................ 110

Figura 51 - Eucaliptos plantados na área do aterro controlado......................................... 112

Figura 52- Área da implantação da fase 1 do Parque Municipal Jardim Primavera. .......... 116

Figura 53- Obras da fase 1- Parque Municipal Jardim Primavera, em 2010.................... 117

Figura 54- Perfuração e medição das concentrações de gases no solo............................. 118

Figura 55- Medição dos gases nas instalações existentes. ........................................... 118

Figura 56- Fase I finalizada do Parque Municipal Jardim Primavera. ............................. 121

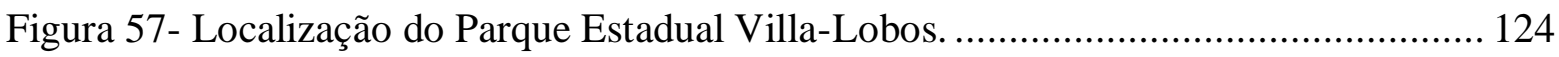

Figura 58- Ocupação da área e do seu entorno no ano de 1958........................................ 125

Figura 59- Movimentação de Terra, na parte sul da área. ............................................. 125

Figura 60- Formação de cava recoberta com vegetação em 1974. .................................... 126

Figura 61 - Intensificação do movimento de terra na parte central da área........................ 126

Figura 62- Placa informativa sobre a implantação do Parque Estadual Villa-Lobos.......... 128

Figura 63- Implantação do Parque Villa Lobos em 1989.............................................. 129

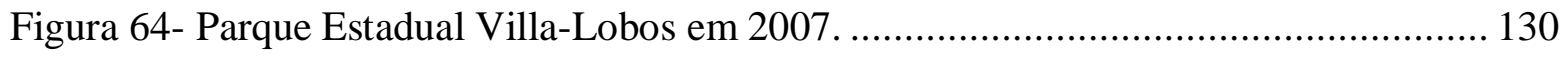

Figura 65-Poços de Monitoramento de água instalado no Parque Estadual Villa-Lobos. .. 135 
Figura 66- Poços de monitoramento de gás instalados no Parque Villa- Lobos................. 136

Figura 67- Área de recreação- Parque Villa Lobos....................................................... 139 


\section{SUMÁRIO}

1. INTRODUÇÃ

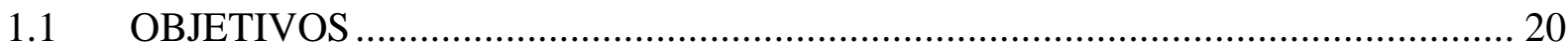

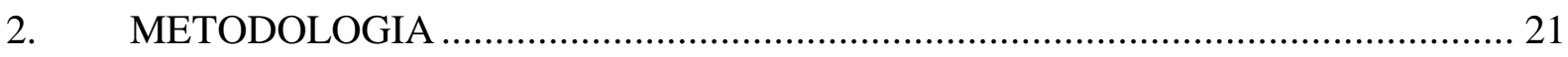

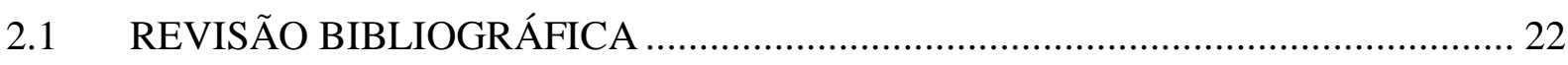

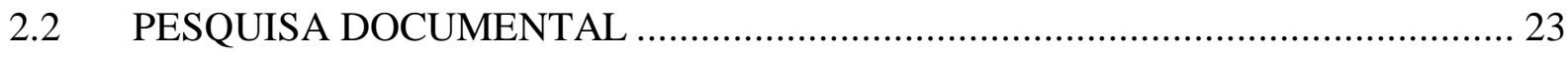

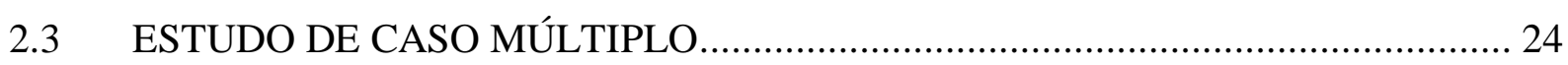

2.3.1 Estudo de Caso 1- Parque Municipal Jardim Primavera ......................................... 24

2.3.2 Estudo de Caso 2- Parque Estadual Villa-Lobos ..................................................... 25

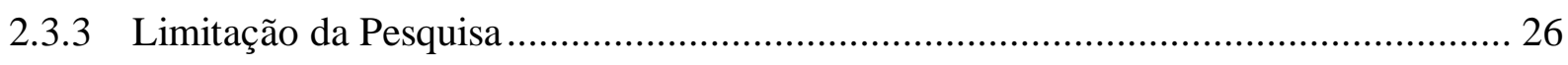

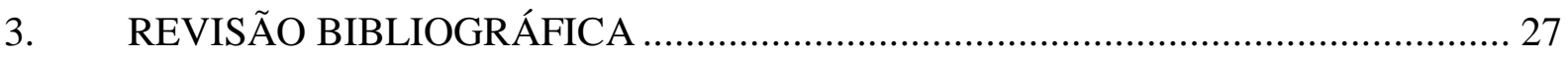

3.1 ÁREAS CONTAMINADAS NO ESPAÇO URBANO ….................................... 27

3.1.1 Gerenciamento de Áreas Contaminadas .............................................................. 30

3.2 LEGISLAÇÕES SOBRE ÁREAS CONTAMINADAS ....................................... 38

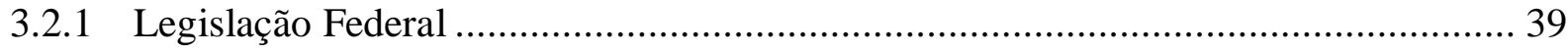

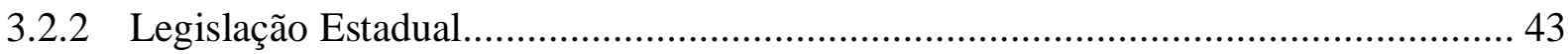

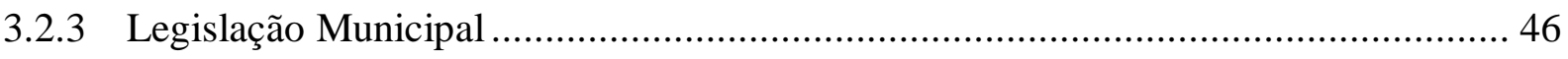

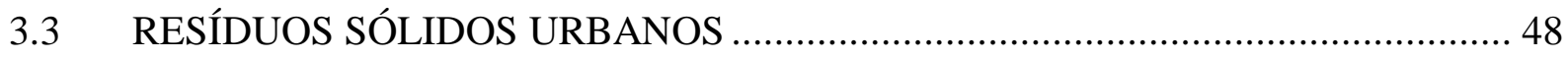

3.3.1 Panorama Internacional: da geração à disposição no solo .................................... 48

3.3.2 Panorama Brasileiro: Município de São Paulo ......................................................... 57

3.3.3 Métodos de Disposição de Resíduos Sólidos no Solo ............................................ 60

3.4 CASOS DE ÁREAS CONTAMINADAS POR RESÍDUOS SÓLIDOS ................... 65

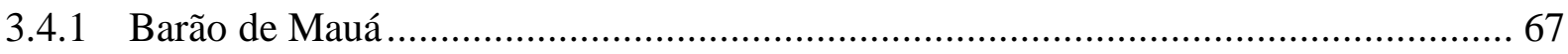

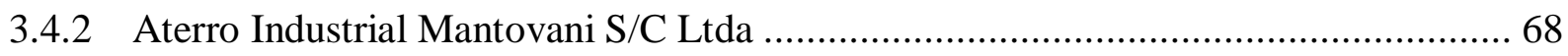

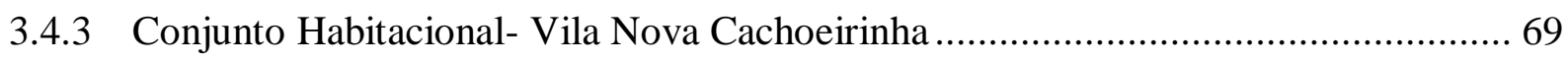

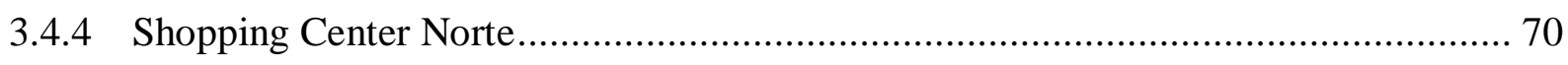

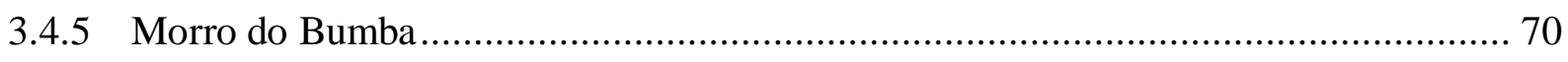

3.5 REQUALIFICAÇÃO DE ÁREAS CONTAMINADAS ....................................... 71

3.5.1 Programas e Incentivos voltados a requalificação de áreas contaminadas ................. 73

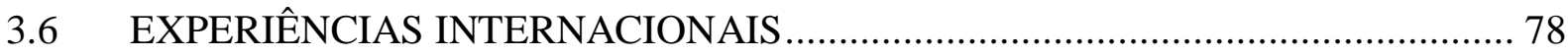

3.6.1 Aterro Brick Township x Painel Solar- Estados Unidos ....................................... 79 


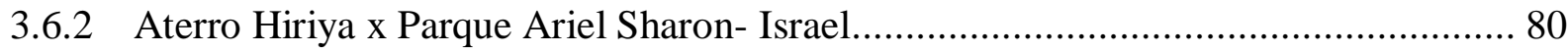

3.6.3 Aterro de Beirolas x Parque Tejo- Portugal ......................................................... 82

3.6.4 Aterro Freskills x Parque Freskills- Nova York ................................................... 85

3.6.5 Aterro Semaku x Ilha Pulau Semaku- Cingapura ................................................. 88

3.6.6 Aterro de Adelaide x Parque Chambers Gully- Austrália ....................................... 89

3.6.7 Lixão x Parque Tianjin Qiaoyuan- China............................................................. 90

3.6.8 Aterro Controlado Bowers x Parque Bowers - Estados Unidos ............................... 92

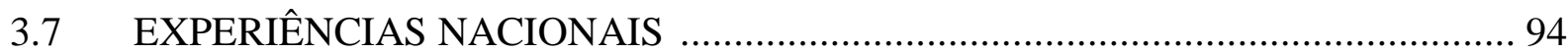

3.7.1 Aterro Carandiru x Parque da Juventude- São Paulo............................................. 95

3.7.2 Aterro Sapopemba x Parque Aterro Sapopemba- São Paulo .................................. 97

3.7.3 Lixão Sambaiatuba x Parque Ambiental Sambaiatuba- São Vicente ......................... 99

3.8 BENEFÍCIOS DOS PARQUES PARA A SAÚDE PÚBLICA ..............................101

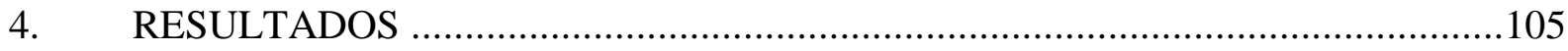

4.1 ESTUDO DE CASO 1: PARQUE MUNICIPAL JARDIM PRIMAVERA .............105

4.1.1 Localização da Área de Estudo....................................................................... 105

4.1.2 Histórico: Uso e Ocupação do Solo .......................................................................106

4.1.3 Início da Investigação Ambiental .................................................................113

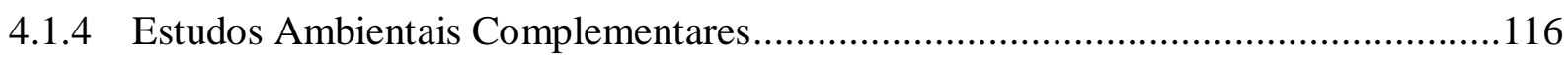

4.1.5 Situação Ambiental atual da área ..................................................................119

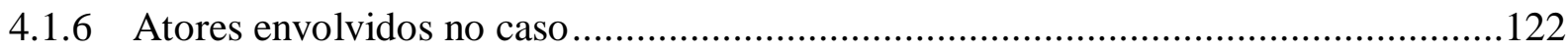

4.1.7 Observações gerais sobre o estudo de Caso 1 .....................................................123

4.2 ESTUDO DE CASO 2: PARQUE ESTADUAL VILLA-LOBOS .........................124

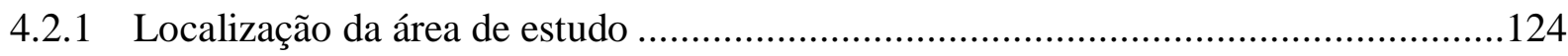

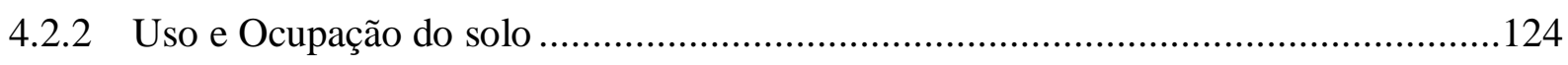

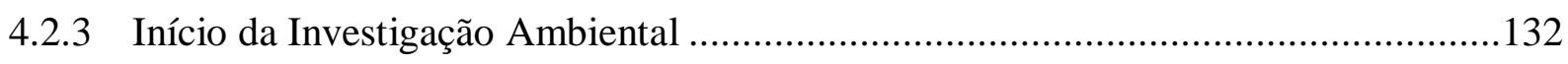

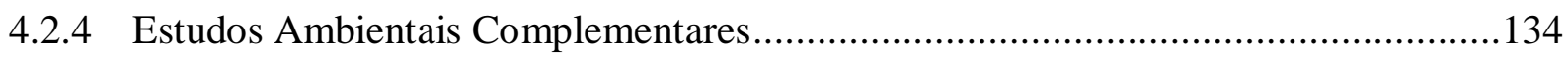

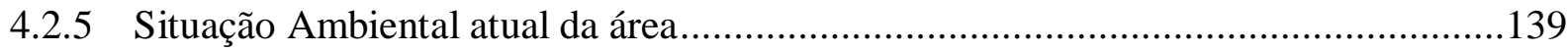

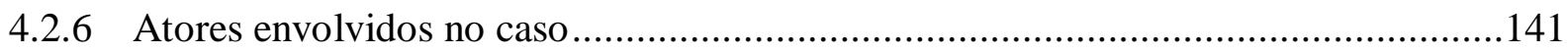

4.2.7 Observações Gerais sobre o estudo de Caso 2 ....................................................142

5. DISCUSSÃO E COMPARAÇÃO DOS ESTUDOS DE CASO ….........................145

5.1 MUNICÍPIO E ESTADO DE SÃO PAULO ............................................... 145

5.1.1 Aspectos em Comum- Estudos de Casos ...............................................................148

5.1.2 Aspectos diferentes- Estudos de Casos .................................................................150 
5.2 FATORES DE SUCESSO NO PROCESSO DE REQUALIFICAÇÃO.....................156

6. CONSIDERAÇÃO FINAIS E RECOMENDAÇÕES.............................................162

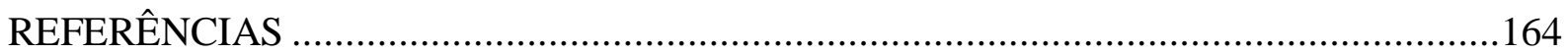




\section{INTRODUÇÃO}

Nos últimos trinta anos, à medida em que a consciência ecológica cresce pelo mundo, tem se notado a necessidade da implantação de diretrizes de planejamento mais sustentável nas grandes cidades. Com a expansão urbana desordenada, cada vez mais presente no território, é nítida a escassez de terras livres e espaços vagos para criação de novas áreas vegetadas na cidade de São Paulo.

A inserção de uma área verde no espaço urbano depende de fatores urbanísticos e econômicos, às vezes inviáveis. Uma opção encontrada e bastante executada em muitos países é a reutilização de áreas contaminadas por resíduos, transformando-as em parques públicos.

Uma área contaminada é aquela em que há comprovação de contaminantes no terreno ou local, em quantidades ou concentrações acima dos valores de referência ambientalmente aceitáveis, podendo causar danos à saúde humana, ecológica ou outro bem a proteger (CETESB, 2001).

Áreas contaminadas degradam a paisagem urbana e interferem na qualidade de vida da população, uma vez que alteram as características naturais dos compartimentos e passam despercebidas pela população (GÜNTHER, 2006). Além disso, é considerada fonte poluidora de grande magnitude e importância para a saúde pública, em função dos riscos à saúde humana e à segurança pública, e da complexidade de gestão (BARROS, 2017).

Segundo o levantamento feito pela CETESB, em dezembro de 2019, foram registradas 6.285 áreas contaminadas no estado de São Paulo. No município de São Paulo, havia 1.771 áreas que tinham passado por processo de reabilitação estando aptas para uso declarado, indicando uma tendência para mudança de uso e ocupação do solo. Os resíduos sólidos constituíam a quarta fonte de contaminação, com 207 áreas contaminadas cadastradas no estado de São Paulo (CETESB, 2019).

Para a reutilização dessas áreas de maneira segura, devem ser realizadas medidas de remediação para recuperá-las, ou compatibilização do uso atual ao futuro.

As medidas de compatibilização baseiam-se na utilização da área que pode ainda estar contaminada, com garantia de não existir vias de transporte de contaminantes ou receptores expostos aos mesmos. Já as medidas de remediação referem-se àquelas que visam à contenção e/ou isolamento e/ou tratamento dos meios contaminados, em busca da 
eliminação ou redução dos níveis de contaminantes a concentrações aceitáveis pela legislação, permitindo que a área possa, posteriormente, ser reabilitada (CETESB, 2001).

Uma área reabilitada para uso declarado é aquela que, depois de submetida às medidas de intervenção, apresenta um nível de risco tolerável para uso futuro, considerando a saúde humana. Reutilizar uma área contaminada significa reinseri-la novamente ao tecido urbano, possibilitando ser um instrumento de requalificação urbana (HABERMANN; GOUVEIA, 2014).

A cidade de São Paulo apresenta uma grande quantidade de áreas submetidas ao gerenciamento de áreas contaminadas comparado a outros estados, especialmente devido ao programa de licenciamento ambiental conduzido pela Cetesb, exigido pelo governo federal, desde o ano de 2000 (BRASIL, 2001).

A criação de áreas verdes e a requalificação dos espaços públicos são relevantes à saúde pública. São considerados como um dos itens imprescindíveis para o bem-estar da população que reside nas grandes cidades e uma grande ferramenta para planejar e desenvolver um ambiente urbano mais sustentável (SANTOS et al. 2019).

$\mathrm{Na}$ malha urbana as áreas verdes são constituídas de praça e parques, com predominância de vegetação arbórea, fornecendo inúmeros benefícios à população. Dentre esses benefícios destacam-se a conservação de espécies da fauna e da flora nativa, a melhoria da qualidade do ar e da água, o equilíbrio climático e consequentemente, o conforto térmico (SANTOS et al. 2019). Devido a isso são utilizadas como indicadores de qualidade de vida e de satisfação coletiva, estando diretamente ligada a atividades de lazer e recreação por meio interação social (MAIA et al. 2018).

Além disso, os espaços verdes estão associados ao bem-estar psicológico, a diminuição dos sintomas de depressão, ansiedade e estresse, além de proporcionar maior qualidade de vida a população (LOCATELLI et al. 2018).

Com isso, para amenizar os problemas urbanos voltados à expansão urbana e a dificuldade de criação de parques públicos, gestores devem repensar o planejamento das cidades considerando o potencial de reutilização das áreas contaminadas como ferramenta sustentável para uso e ocupação do solo.

Dentro desse panorama, o presente estudo, objetiva estudar processos de requalificação de áreas contaminadas por resíduos para transformação em parques. Baseia-se em revisão de literatura nacional e internacional e em pesquisa documental, e realiza estudo de caso de dois parques localizados em áreas reabilitadas no município de São Paulo. 


\subsection{OBJETIVOS}

O objetivo geral da pesquisa consistiu em estudar processos de requalificação de áreas contaminadas por resíduos para transformação em parques, tendo como estudo de caso dois parques localizados no município de São Paulo e experiências internacionais.

Os objetivos específicos incluíram:

- Realizar revisão da literatura e da legislação sobre o tema;

- Historiar o processo de ocupação da área e de implantação do Parque Municipal Jardim Primavera e do Parque Estadual Villa-Lobos;

- Identificar os principais atores envolvidos no processo de requalificação do Parque Municipal Jardim Primavera e do Parque Estadual Villa-Lobos;

- Descrever a situação ambiental atual dos casos estudados;

- Compreender os fatores de sucesso na requalificação de áreas contaminadas no município de São Paulo;

- Apresentar casos internacionais de requalificação de áreas contaminadas por resíduos e transformação em parques. 


\section{METODOLOGIA}

Esta pesquisa possui uma abordagem de caráter exploratória, na medida em que buscou se aprofundar sobre determinado assunto pouco estudado, ou com aspectos específicos de uma teoria ampla (BRANSKI et al. 2015, p.2).

Também é descritiva, pois objetivou a descrição de um fenômeno sobre determinada realidade, no caso (GIL, 2007, p.44), o processo de requalificação de áreas contaminadas por resíduos localizadas no município de São Paulo. Além disso, caracteriza-se como uma pesquisa qualitativa, pois tem o ambiente natural como fonte direta dos dados, buscando as causas da existência dele, procurando explicar sua origem, suas relações, suas mudanças e as consequências que terão para a vida humana (TRIVIÑOS, 1987, p.129-130).

A pesquisa também se enquadra como um estudo de caso que, de acordo com YIN (2010, p.24), é um método de investigação empírica que estuda os fenômenos contemporâneos individuais, grupais, organizacionais, sociais e políticos. Esse estudo, dentro do contexto de realidade possibilita entender uma decisão ou conjunto de decisões, do porquê que elas foram tomadas, como elas são implementadas e quais seus resultados.

GIL (2007, p.72) destaca que o estudo de caso é um estudo de um ou de poucos objetos, de modo que permite o seu conhecimento amplo e detalhado.

Os métodos adotados para elaboração da pesquisa foram separados em três etapas, afim de facilitar o entendimento e a organização do trabalho, conforme ilustrado na figura 1.

Figura 1- Métodos adotados para elaboração da pesquisa.

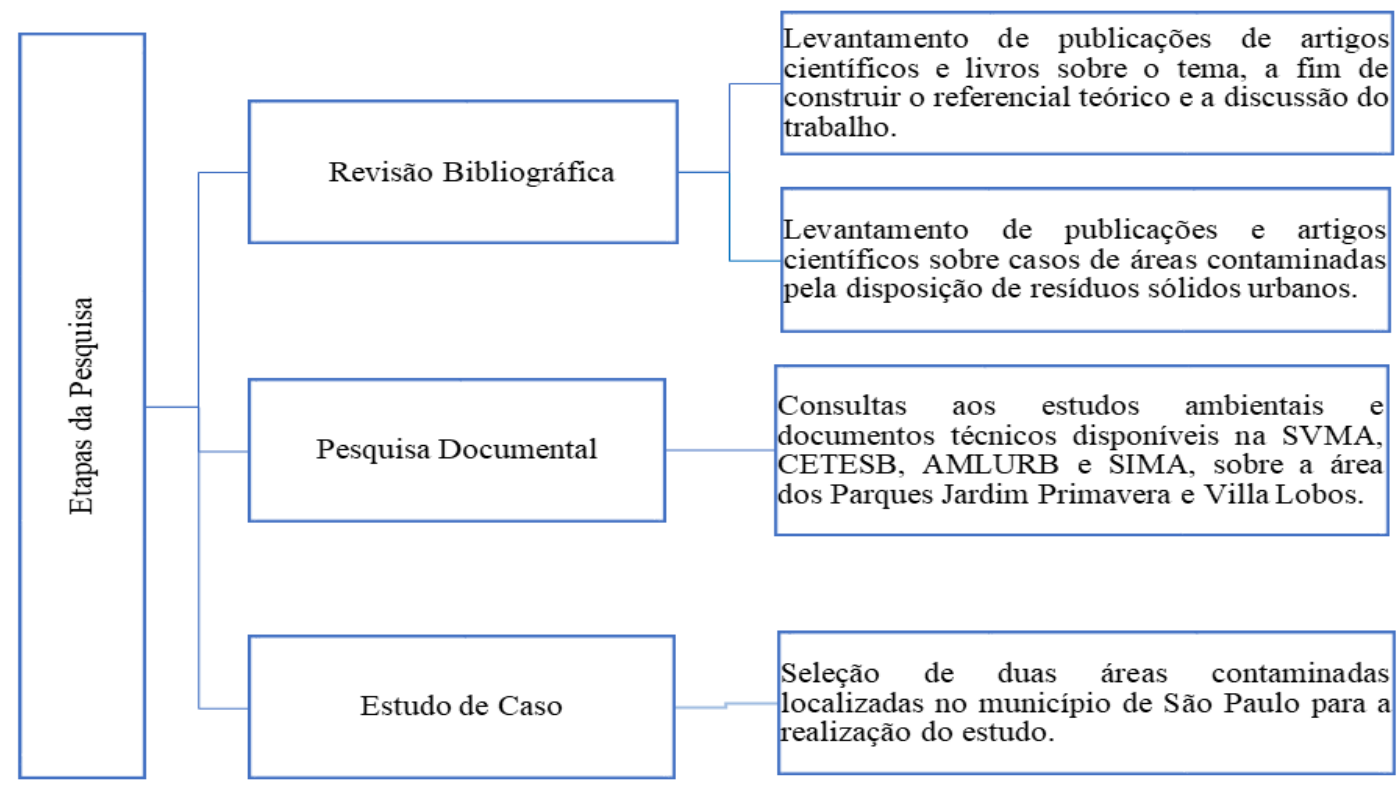

Fonte: Elaborado pela autora. 


\subsection{REVISÃO BIBLIOGRÁFICA}

Primeiramente, foi realizada pesquisa bibliográfica composta por dados secundários baseada em um material já elaborado por diversos autores, constituído principalmente de livros e artigos científicos (GIL, 2007, p.65).

Sua finalidade é colocar o pesquisador em contato direto com tudo o que foi escrito sobre determinado assunto. A sua principal vantagem reside no fato de propiciar a análise de um tema sob novo enfoque ou abordagem, chegando a conclusões inovadoras (MARCONI e LAKATOS, 2008, p.185).

Para o presente trabalho, a pesquisa bibliográfica foi utilizada de forma abrangente relacionada a aspectos conceituais, técnicos e institucionais sobre áreas contaminadas, gerenciamento e legislações; áreas contaminadas e resíduos sólidos; casos de áreas contaminadas por resíduos; requalificação de áreas contaminadas; programas e incentivos fiscais voltados à requalificação e experiências práticas de requalificação em parques, a fim de construir o referencial teórico para a discussão do trabalho.

Para tanto, foram realizadas consultas nas principais bases de dados indexadas, como o Portal de Periódicos da Capes, Bancos e Bibliotecas Digitais de Teses e Dissertações de Universidades Brasileiras, bases bibliográficas Scielo e Web of Science, assim como em livros da área.

Algumas teses utilizadas foram: "De Áreas Degradadas a Espaços VegetadosPotencialidades de áreas vazias, abandonadas e subutilizadas como parte da infraestrutura verde urbana” de Patrícia Mara Sanches (2011) e Requalificação dos aterros desativados (brownfields) no município de São Paulo: Parques (greenfields) Raposo Tavares e Jardim Primavera" de Luzia Helena dos Santos Barros (2011).

Para pesquisa em bases bibliográficas foram usados como descritores: áreas contaminadas, requalificação urbana, disposição irregular de resíduos, parques urbanos, aterros controlados, em português e inglês, dos últimos 20 anos.

No âmbito internacional, as fontes para consulta incluíram Websites da USEPASuperfund Sucess Stories e da Newlands- Cases Studies. Os critérios de escolha para os projetos bem-sucedidos foram os usos e a ocupações da área e o seu uso atual ou futuro. 


\subsection{PESQUISA DOCUMENTAL}

De acordo com Gil (2007, p.66), a pesquisa documental se assemelha à pesquisa bibliográfica com a diferença na natureza das fontes. Ela vale-se de materiais que não receberam ainda um tratamento analítico caracterizado como dados primários, tais como: documentos oficiais públicos, reportagens de jornais, cartas, contratos, filmes, diários, fotografias, etc. Também existem os documentos que já foram analisados de alguma forma representados como dados secundários, tais como: relatórios de pesquisa, relatórios de empresas, tabelas estatísticas, etc.

MARCONI e LAKATOS (2008, p.178) ressaltam que a pesquisa documental pode ser feita no momento em que o fato ou fenômeno ocorre, ou depois, auxiliando a compreensão do universo utilizando três variáveis: fontes escritas ou não; fontes primárias ou secundárias; contemporâneas ou retrospectivas.

Neste sentido, a pesquisa documental foi realizada através de agendamentos para consultar os processos administrativos existentes nas instituições públicas Secretaria Municipal do Verde e do Meio Ambiente de São Paulo (SVMA), a Companhia Ambiental do Estado de São Paulo (CETESB) e a Autoridade Municipal de Limpeza Urbana de São Paulo (AMLURB).

O levantamento de dados secundários baseados nos estudos ambientais e pareces técnicos sobre a área contaminada do Parque Municipal Jardim Primavera foi realizado no período de fev. /2018 a dez. /2018. Esse levantamento contemplou dados sobre o histórico do uso e ocupação do solo; tipo de contaminação; meios impactados; os contaminantes; etapas do gerenciamento ambiental executadas; atores envolvidos no caso; medidas de intervenção tomadas; implantação do parque e situação ambiental atual da área.

Posteriormente, entre o período de maio/2019 a junho/2019 foi realizado agendamento na Secretaria de Infraestrutura e Meio Ambiente do Estado de São Paulo (SIMA), Coordenadoria de Parque Urbanos (CPU) para realizar consultas aos documentos ambientais e técnicos sobre o Parque Villa Lobos, além de consultas em estudos científicos e dissertações que abordam o parque. Essa consulta visou obter informações detalhadas sobre o Parque Estadual Villa-Lobos, como realizado para o Parque Municipal Jardim Primavera. 


\subsection{ESTUDO DE CASO MÚLTIPLO}

Segundo GIL (2002, p.54) o estudo de caso é uma modalidade de pesquisa amplamente utilizada nas ciências. Na pesquisa qualitativa, este tipo de estudo apresenta como vantagem a sua capacidade de lidar com uma ampla variedade de evidências como documentos, artefatos, entrevistas e observações, possibilitando identificar fenômenos atuais inseridos no seu próprio contexto, além de contar com a pesquisa histórica (YIN 2010, p. 32).

Yin, $2009^{1}$ (apud BRANSKI et al. 2015, p. 1) destaca que é muito útil para investigar novos conceitos, bem como para verificar como são aplicados e utilizados na prática elementos de uma teoria. Também é possível se adquirir uma visão global do problema ou de identificar fatores que influenciam ou são por ele influenciados (GIL 2002, p.55).

Além disso, o estudo de caso pode ser constituído tanto de um único caso, quanto de múltiplos casos, aspecto adotado nesse estudo.

GIL (2002, p.139) afirma que, de modo geral, a utilização de estudo de casos múltiplos proporciona evidências inseridas em diferentes contextos, sendo um deles para o pesquisador, permitindo explicar, descrever e comparar os fenômenos entre os casos em questão (TRIVIÑOS, 1987. p.136).

Sendo assim, para compreender o processo de requalificação de áreas contaminadas no contexto urbano, foram selecionadas duas áreas contaminadas por resíduos localizadas no município de São Paulo com uso declarado para a implantação de parque público. A seguir segue um breve descritivo de cada um dos casos estudados.

\subsubsection{Estudo de Caso 1- Parque Municipal Jardim Primavera}

A partir do conhecimento das áreas contaminadas por resíduos existentes no munícipio de São Paulo foi selecionada a área do Parque Municipal Jardim Primavera para a realização do estudo.

A área do Parque Municipal Jardim Primavera está situada na confluência das Avenidas Antônio Louzada Antunes, Mimo de Vênus e Rua Arareua s/n (figura 2), junto ao

\footnotetext{
${ }^{1}$ Yin, R.K. Case study research, design and methods (applied social research methods). Thousand Oaks. California: Sage Publications. 2009.
} 
sistema viário Jacu-pêssego. Está inserida no extremo da zona leste do município, no distrito de Vila Jacuí, em São Miguel Paulista.

No ano de 2002, a Prefeitura de São Paulo sancionou a Lei Municipal 13.308/2002, criando o Parque Municipal Jardim Primavera.

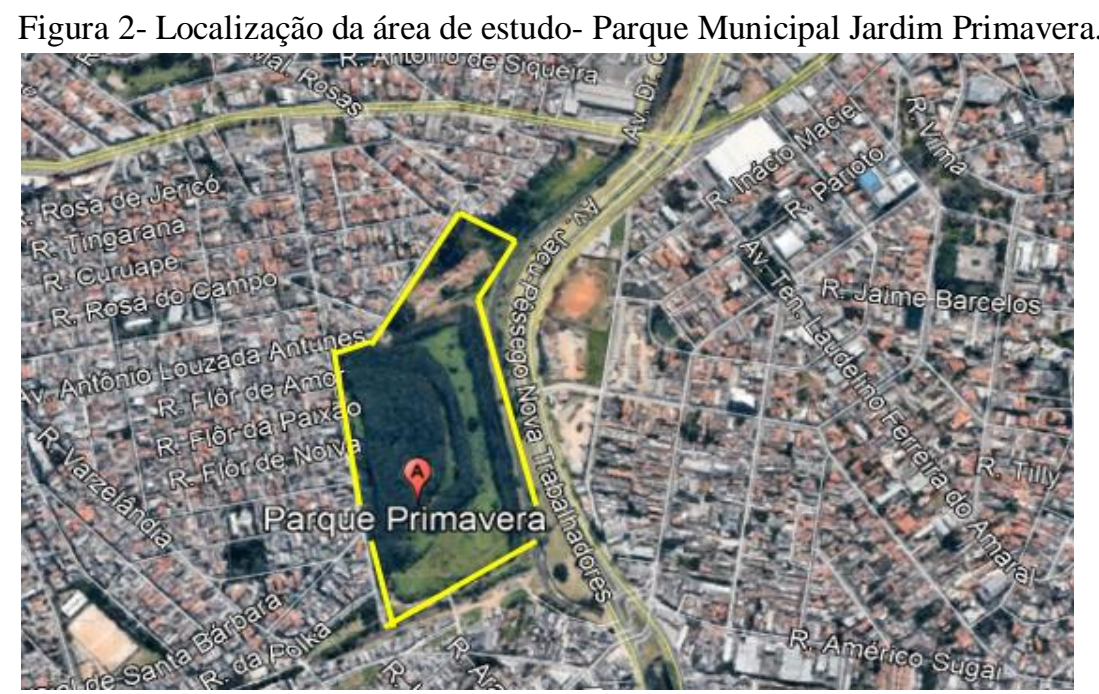

Extraído de: GOOGLE EARTH, 2019.

Os critérios de seleção da área contaminada para o estudo foram baseados nos seguintes aspectos:

- Área pouco estudada e explorada;

- Tempo no agendamento dos estudos ambientais na SVMA;

- Tempo para a implantação e finalização das obras do parque;

- Poucas informações disponíveis sobre a área por parte do Ministério Público do Estado de São Paulo;

- Potencial de reutilização da área para novos usos;

- Benefícios que o parque pode favorecer à comunidade do entorno e aos futuros usuários.

\subsubsection{Estudo de Caso 2- Parque Estadual Villa-Lobos}

Buscando compreender o processo de requalificação de áreas contaminadas por resíduos, foi selecionada a área contaminada do Parque Villa Lobos por ser considerado um caso bem sucedido no município de São Paulo. 
A área do Parque Estadual Villa Lobos (figura 3) está localizada no bairro de Alto de Pinheiros, na zona oeste de São Paulo, Subprefeitura de Pinheiros, na Avenida Professor Fonseca Rodrigues, 2001.

O parque foi projetado para ser a cidade da música em homenagem ao compositor brasileiro Villa-Lobos, concluído no ano de 2006.

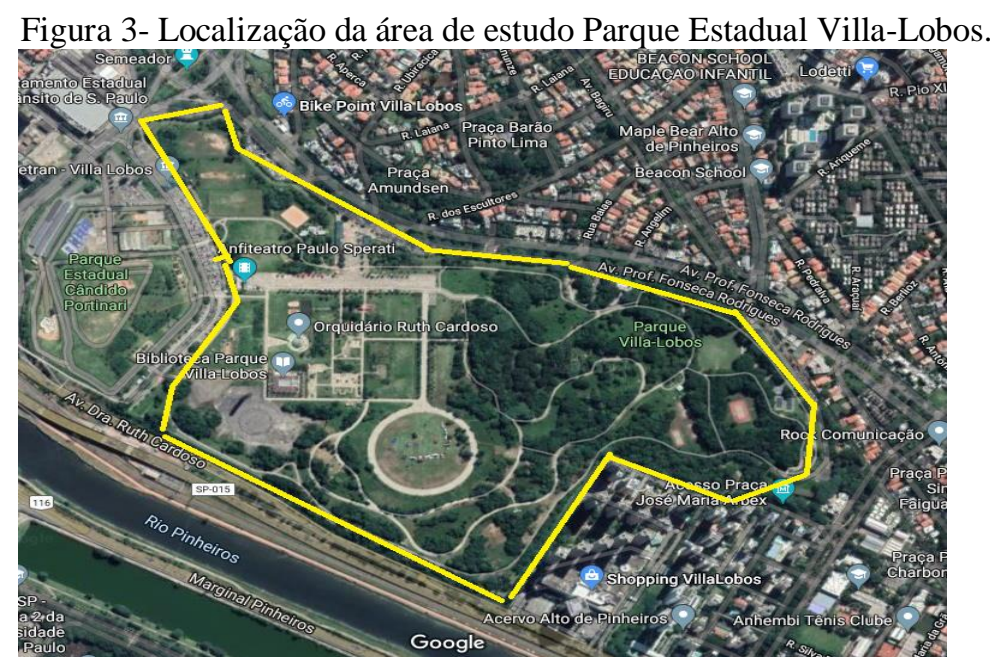

Extraído de: GOOGLE EARTH, 2019.

Os critérios para a escolha da área contaminada em fase concluída foram:

- Localizada dentro do contexto urbano no município de São Paulo;

- Características semelhantes como: uso e ocupação do solo e fonte de poluição;

- Período de funcionamento e desativação da fonte poluidora;

- Compartimentos contaminados (solo, água superficial e subterrânea);

- Considerado como caso de sucesso de requalificação de área contaminada por resíduos;

- Uso atual ou futuro da área.

\subsubsection{Limitação da Pesquisa}

Para a realização da pesquisa as dificuldades e limitações identificadas foram:

- Dificuldade em encontrar trabalhos científicos nacionais e internacionais de áreas contaminadas por resíduos inseridas no contexto urbano e requalificadas em parques. Ainda não há muitas pesquisas sobre o tema. 


\section{REVISÃO BIBLIOGRÁFICA}

\section{1 ÁREAS CONTAMINADAS NO ESPAÇO URBANO}

Ao longo das últimas décadas, a humanidade vem passando por um rápido e maciço processo de crescimento populacional e de urbanização, que passou a exercer uma pressão constante na cidade, uma vez que a infraestrutura e os serviços não o acompanharam, causando diversos impactos ambientais e sociais.

Esses impactos são oriundos das diversas fontes poluidoras (figura 4), que quando manuseadas sem controle e fiscalização, acabam resultando na degradação da qualidade do solo, água subterrânea e/ou de outros bens a proteger (AMARO et al. 2018).

A Política Nacional do Meio Ambiente- PNMA na Lei Federal n. 6.938/1981, define degradação da qualidade ambiental, como:

Art. 3, II- "alteração adversa das características do meio ambiente", em outras palavras, mudança artificial ou perturbações negativas de causa no compartimento natural (BRASIL, 1981).

Essas mudanças e/ou perturbações estão diretamente voltadas à intensificação das atividades humanas, a melhoria do nível de vida das pessoas e a busca crescente por matéria prima para produção de novos produtos (MMA, 2016).

SÁNCHEZ (2004) afirma que o agente causador da degradação ambiental é sempre o ser humano, pois processos naturais não degradam o ambiente apenas causam mudança.

Figura 4- Principais fontes de contaminação do solo e água subterrânea.

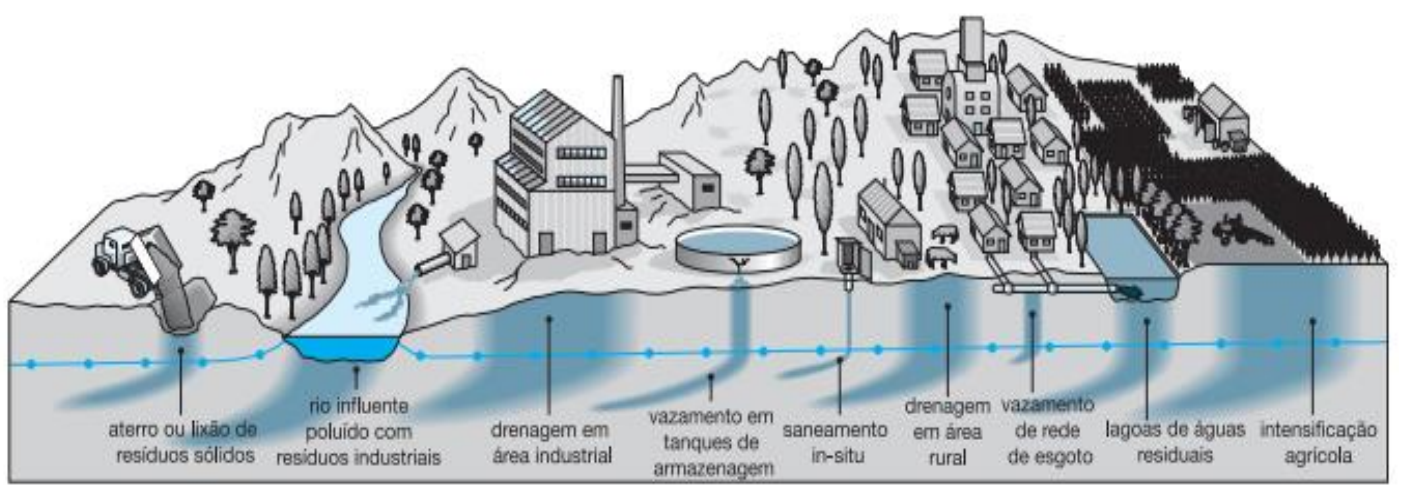

Extraído de: FOSTER et al. 2006, p. 4. 
Dentro de um universo de áreas ocupadas pelos assentamentos urbanos e mais a dinâmica da cidade, diversos são os exemplos em que se pode identificar áreas degradadas, poluídas e/ou contaminadas, objeto desse estudo.

ROCCA (2019) afirma que esse cenário representa a consequência do modelo de desenvolvimento sem sustentação e sem responsabilidade social adotado no passado, que hoje compromete a capacidade produtiva do solo, exigindo de tal maneira, a sua recuperação para um novo uso ou função.

Desta maneira, para classificar uma área como contaminada, se faz necessário o entendimento correto de contaminação, pois muitas vezes confundido de maneira errônea com poluição.

Poluir é um verbo de origem latina, polluere e significa profanar, manchar, sujar (SÁNCHEZ, 2006. p.24). A Lei Estadual de São Paulo N. 997/1976, aponta a definição como tal:
Art-2. A presença, o lançamento ou a liberação, nas águas, no ar ou no solo, de toda e qualquer forma de matéria ou energia, com intensidade, em quantidade de concentração ou com características em desacordo com as que forem estabelecidas e decorrência desta lei, ou que se tornem ou possam tornar as águas, o ar ou solo: I - impróprios, nocivos ou ofensivos à saúde;
II - inconvenientes ao bem estar público;
III - danosos aos materiais, à fauna e à flora:
IV - prejudiciais à segurança, ao uso e gozo da propriedade e às atividades normais da comunidade (SÃO PAULO (estado), 1976. p.1).

Para o conceito de contaminação, a definição estabelecida em nível federal pela Resolução Conama N. 420/2009, apresenta-se:

\begin{abstract}
Art. $6^{\circ}-\mathrm{V}$ : Presença de substância (s) química (s) no ar, água ou solo, decorrentes de atividades antrópicas, em concentrações tais que restrinjam a utilização desse recurso ambiental para os usos atual ou pretendido, definidas com base em avaliação de risco à saúde humana, assim como aos bens a proteger, em cenário de exposição padronizado ou específico (BRASIL, 2009. p.2).
\end{abstract}

Essa distinção é de extrema importância, pois uma área contaminada exige uma série de ações que deverá ser tomada pelo responsável legal e órgão ambiental competente. É importante destacar que nem sempre uma área poluída está necessariamente contaminada, porém toda área contaminada está poluída (SÁNCHEZ, 2001; SPÍNOLA et al. 2014).

Sendo assim, define-se área contaminada como:

"Local, área, terreno, instalação, edificação ou benfeitoria onde há comprovadamente quantidades ou concentrações de quaisquer substâncias químicas perigosas ou outros agentes perigosos, que tenham sido depositados, enterrados, armazenados ou infiltrados de forma planejada, acidental ou natural, 
que causem ou possam causar danos à saúde humana, ao meio ambiente ou a outros bens a proteger" (CETESB, 2001; SÃO PAULO (estado), 2013).

No estado de São Paulo, as definições vigentes de áreas contaminadas trazidas pelas legislações são parecidas, conforme dispostas no quadro 1.

\begin{tabular}{|c|c|c|}
\hline $\begin{array}{c}\text { Política Estadual de } \\
\text { Resíduos Sólidos } \\
(\mathbf{2 0 0 6 )}\end{array}$ & $\begin{array}{c}\text { Decreto N. 59.263/ } \\
(2013)\end{array}$ & $\begin{array}{l}\text { Política Nacional de } \\
\text { Resíduos (2010) }\end{array}$ \\
\hline $\begin{array}{c}\text { Área, terreno, local, } \\
\text { instalação, edificação } \\
\text { ou benfeitoria que } \\
\text { contém quantidades } \\
\text { ou concentrações de } \\
\text { matéria em condições } \\
\text { que causem ou } \\
\text { possam causar danos } \\
\text { à saúde humana, ao } \\
\text { meio ambiente e a } \\
\text { outro bem a proteger } \\
\text { (Art. } 5^{\circ}, \text { IX). }\end{array}$ & $\begin{array}{c}\text { Área, terreno, local, } \\
\text { instalação, edificação } \\
\text { ou benfeitoria que } \\
\text { contenha quantidades } \\
\text { ou concentrações de } \\
\text { matéria em condições } \\
\text { que causem ou possam } \\
\text { causar danos à saúde } \\
\text { humana, ao meio } \\
\text { ambiente ou a outro } \\
\text { bem a proteger (Art. } 3^{\circ}, \\
\text { II). }\end{array}$ & $\begin{array}{l}\text { Local onde há } \\
\text { contaminação } \\
\text { causada pela } \\
\text { disposição, regular } \\
\text { ou irregular, de } \\
\text { quaisquer } \\
\text { substâncias ou } \\
\text { resíduos (Art.3, II). }\end{array}$ \\
\hline
\end{tabular}

Nas áreas contaminadas, os poluentes ou contaminantes podem se concentrar e/ou ser transportados em diferentes compartimentos do ambiente. Isso pode ocasionar diversos impactos ao espaço urbano, como: tornar o uso da área desinteressante com o esvaziamento de atividades e abandono de edificações; impulsionar a concorrência para locais mais atraentes por causa da ação do capital imobiliário; aumentar a expansão urbana pela busca de novas áreas e acarretar na inadequação da estrutura física às novas demandas (HABERMANN e GOUVEIA, 2014; VARGAS, 2014).

Além disso, afetam diretamente o uso e ocupação do solo levando a uma depreciação do capital imobiliário no local e/ou no entorno imediato, promovendo o surgimento de atividades irregulares de toda ordem (VARGAS, 2014).

SEPE e SILVA (2004), citam que outra consequência é o espalhamento da mancha urbana para a ocupação de áreas livres greenfields, em detrimento de áreas já urbanizadas não utilizadas.

O termo greenfield refere-se às áreas naturais ou rurais que ainda não foram ocupadas pelo processo de urbanização (MORINAGA, 2007; SANCHES, 2011).

Entretanto, devido ao cenário relacionado à expansão urbana por novas áreas, a redução do valor dos imóveis, as restrições ao desenvolvimento urbano, o aumento dos gastos com infraestrutura e serviços urbanos, a perda da qualidade ambiental e a presença 
das áreas contaminadas no espaço urbano, os órgãos ambientais e de saúde pública no contexto nacional e internacional veem apresentando uma atenção visando a recuperação dessas áreas.

GÜNTHER (2006) afirma que as áreas contaminadas apresentam potencial para reutilização após passar pelo processo de remediação, eliminando o risco à saúde ou tornando-o aceitável, antes de ser revitalizada e reinserida no meio urbano. Ainda a autora destaca que a reutilização é uma estratégia que incentiva a reintegração da área na malha urbana, mas para isso, requer critérios, avaliação e tomada de decisão no campo da saúde ambiental, principalmente quanto ao uso pretendido e as características da contaminação.

Desta forma, para iniciar ações voltadas para a recuperação de áreas contaminadas e nortear a gestão de reuso dessas áreas, a Companhia Ambiental do Estado de São PauloCETESB, ligada à Secretaria do Meio Ambiente de São Paulo-SMA, lançou em 2001 o Manual de Gerenciamento de Áreas Contaminadas (CETESB, 2001).

Este manual refere-se a metodologia de gerenciamento e encaminhamento de soluções à questão do ponto de vista da recuperação ambiental. Também elaborou o Guia para Avaliação do Potencial de Contaminação em Imóveis (CETESB, 2003) estabelecendo as precauções e os procedimentos a serem adotados na aquisição de um imóvel ou até mesmo no início do desenvolvimento de projeto de reutilização.

A identificação e o registro das áreas contaminadas, assim como de suas características quantitativas e qualitativas são fundamentais para a criação de cadastros, servindo como instrumentos de gestão no âmbito público utilizado por empresas e corporações privadas (MARKER, 2013).

Os cadastros referentes a qualidade do solo e áreas contaminadas, variam segundo sua abrangência e seu objetivo, o que determina o tipo de dados e informações disponibilizadas (BRASIL, 2009; MARKER, 2013).

Entretanto, para facilitar as medidas que devem ser tomadas no problema ambiental na área contaminada (AC) é realizado o gerenciamento de áreas contaminadas (GAC), visando minimizar os riscos que estão sujeitos à população e ao meio ambiente (MMA, 2019).

\subsubsection{Gerenciamento de Áreas Contaminadas}

O gerenciamento de áreas contaminadas é executado com base na análise progressiva do local, ou seja, por meio de uma estratégia constituída por etapas sequenciais de extrema 
importância, em que a informação obtida em cada etapa é a base para a execução da etapa posterior (CETESB, 2007).

O processo envolve a identificação de área potencialmente contaminada, a investigação, e se constatada a contaminação, o detalhamento da mesma, a avaliação de risco, as medidas de intervenção, monitoramento e demais ações necessárias visando a reabilitação da área (CETESB, 2007; MMA, 2019).

Entretanto, destaca-se que o termo reabilitação está inserido no contexto de recuperação de áreas degradadas. Segundo SÁNCHEZ (2004) a recuperação ambiental engloba dois conceitos importantes: a restauração e a reabilitação.

Restauração significa utilizar a remediação na área contaminada, buscando tornar possível todas as formas de uso como se não tivesse ocorrido a contaminação, ou seja, o retorno das condições naturais de origem. E reabilitação, envolve ações de recuperação na área contaminada para tornar o local apto para novos usos, no qual pode haver restrições (SÁNCHEZ, 2004. p.86).

A seguir a figura 5 demonstra, simplificadamente, a metodologia do gerenciamento de áreas contaminadas em forma esquemática, identificando o cadastro de áreas contaminadas, as etapas do gerenciamento e os caminhos pelos quais os dados obtidos são registrados.

A metodologia é composta por dois processos: o de identificação e o de reabilitação de áreas contaminadas.

Figura 5- Etapas do Gerenciamento de Áreas Contaminadas.

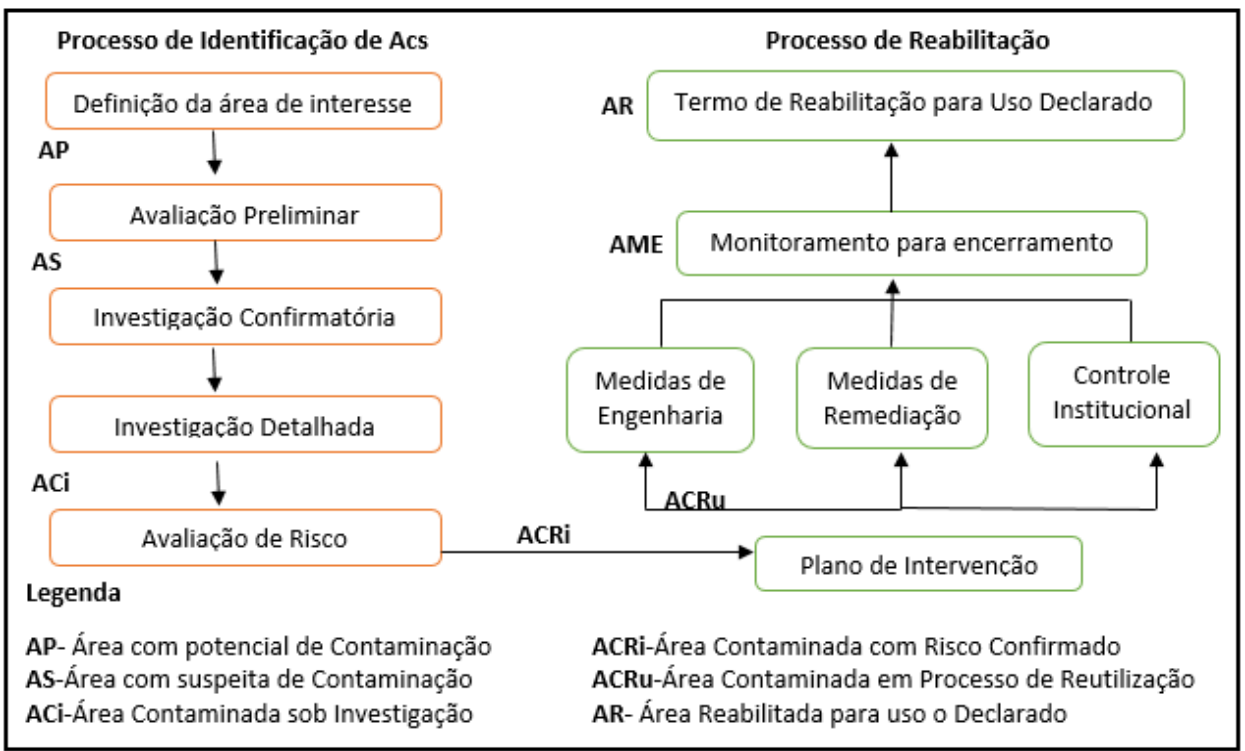

Adaptado de: IPT, 2018. Elaborado pela autora. 
De acordo com o Art. $8^{\circ}$ do Decreto Estadual $n^{\circ} 59.263 / 2013$ as áreas podem ser separadas em classes distintas, em conformidade com o desenvolvimento das etapas do processo de identificação e reabilitação, descritas no quadro 2.

Quadro 2- Definições das categorias das áreas.

\begin{tabular}{|c|c|}
\hline Categoria da Área & Descrição da Área \\
\hline $\begin{array}{l}\text { Área com Potencial de } \\
\text { Contaminação (AP) }\end{array}$ & $\begin{array}{l}\text { Área, terreno, local, instalação, edificação ou } \\
\text { benfeitoria onde são ou foram desenvolvidas atividades } \\
\text { que, por suas características, possam acumular } \\
\text { quantidades ou concentrações de matéria em condições } \\
\text { que a tornem contaminada. }\end{array}$ \\
\hline $\begin{array}{c}\text { Área Suspeita de Contaminação } \\
\text { (AS) }\end{array}$ & $\begin{array}{l}\text { Área, terreno, local, instalação, edificação ou } \\
\text { benfeitoria com indícios de ser uma área contaminada } \\
\text { conforme resultado da avaliação preliminar. }\end{array}$ \\
\hline $\begin{array}{l}\text { Área Contaminada sob } \\
\text { Investigação (ACI) }\end{array}$ & $\begin{array}{l}\text { Área onde foram constatadas por meio de investigação } \\
\text { confirmatória concentrações de contaminantes que } \\
\text { colocam, ou podem colocar, em risco os bens a } \\
\text { proteger. }\end{array}$ \\
\hline $\begin{array}{c}\text { Área Contaminada com Risco } \\
\text { Confirmado (ACRi) }\end{array}$ & $\begin{array}{l}\text { Área onde foi constatada, por meio de investigação } \\
\text { detalhada e avaliação de risco, contaminação no solo } \\
\text { ou em águas subterrâneas, a existência de risco à saúde } \\
\text { ou à vida humana, ecológico, ou onde foram } \\
\text { ultrapassados os padrões legais aplicáveis. }\end{array}$ \\
\hline $\begin{array}{l}\text { Área Contaminada em Processo } \\
\text { em Remediação (ACRe) }\end{array}$ & $\begin{array}{l}\text { Área onde estão sendo aplicadas medidas de } \\
\text { remediação visando a eliminação da massa de } \\
\text { contaminantes ou, na impossibilidade técnica ou } \\
\text { econômica, sua redução ou a execução de medidas } \\
\text { contenção e/ou isolamento. }\end{array}$ \\
\hline $\begin{array}{c}\text { Área Contaminada em Processo } \\
\text { de Reutilização (ACRu) }\end{array}$ & $\begin{array}{l}\text { Área contaminada onde se pretende estabelecer um uso } \\
\text { do solo diferente daquele que originou a contaminação, } \\
\text { com a eliminação, ou a redução a níveis aceitáveis, dos } \\
\text { riscos aos bens a proteger, decorrentes da } \\
\text { contaminação. }\end{array}$ \\
\hline $\begin{array}{l}\text { Área em Processo de } \\
\text { Monitoramento para } \\
\text { Encerramento (AME) }\end{array}$ & $\begin{array}{l}\text { Área na qual não foi constatado risco ou as metas de } \\
\text { remediação foram atingidas após implantadas as } \\
\text { medidas de remediação, encontrando-se em processo } \\
\text { de monitoramento para verificação da manutenção das } \\
\text { concentrações em níveis aceitáveis. }\end{array}$ \\
\hline $\begin{array}{c}\text { Área Reabilitada para o Uso } \\
\text { Declarado (AR) }\end{array}$ & $\begin{array}{l}\text { Área, terreno, local, instalação, edificação ou } \\
\text { benfeitoria anteriormente contaminada que, depois de } \\
\text { submetida às medidas de intervenção, ainda que não } \\
\text { tenha sido totalmente eliminada a massa de } \\
\text { contaminação, tem restabelecido o nível de risco } \\
\text { aceitável à saúde humana, ao meio ambiente e a outros } \\
\text { bens a proteger. }\end{array}$ \\
\hline
\end{tabular}

Extraído de: SÃO PAULO (estado), 2013.

Ainda segundo a Decisão de Diretoria no 038/2017/C da CETESB, após a definição da área de interesse a ser investigada, deve-se realizar a avaliação inicial com base nas informações disponíveis públicas ou privadas, afim de fundamentar a suspeita de contaminação no local. 
Conforme $\S 1^{\circ}$ do Art. 20 do Decreto Estadual $n^{\circ} 59.263 / 2013$, considera-se uma área com indício ou suspeita de contaminação a constatação da ocorrência de vazamentos ou o manejo inadequado de substâncias, matérias primas, produtos, resíduos e efluentes, bem como a presença das mesmas na superfície do solo ou nas paredes e pisos das edificações e a existência de instalações com projeto inadequado ou fora das normas existentes, como ilustra a figura 6.

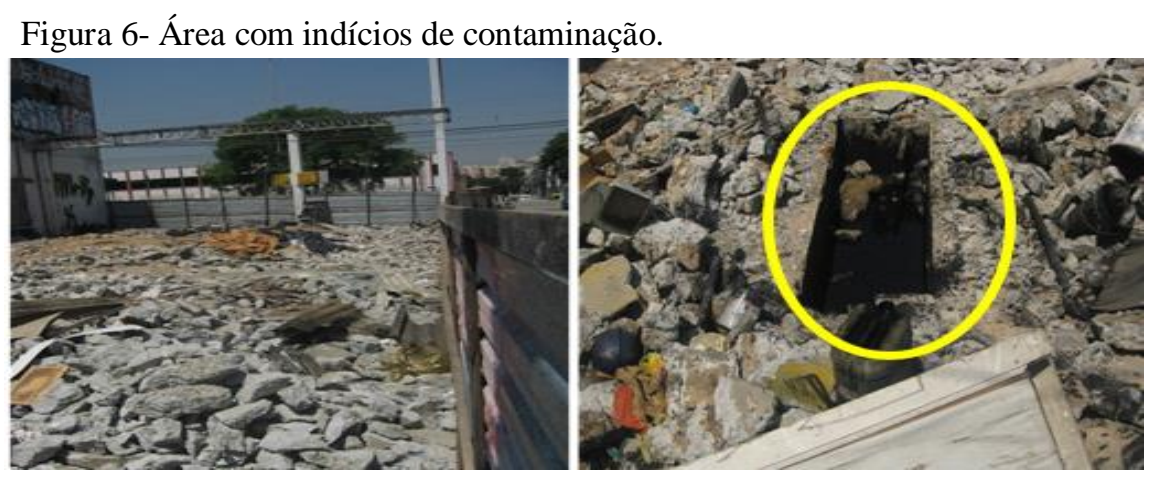

Extraído de: SVMA, 2016.

Nessa etapa o objetivo é caracterizar as atividades desenvolvidas e em desenvolvimento na área sob avaliação, identificar as áreas fonte e as fontes potenciais de contaminação (ou mesmo fontes primárias de contaminação) e constatar evidências, indícios ou fatos que permitam suspeitar da existência de contaminação, englobando: levantamento da documentação existente sobre a área, notadamente aquela disponível na própria empresa, nos processos administrativos da CETESB e na Prefeitura Municipal; levantamento de dados e informações relativos ao histórico da ocupação da área; a descrição de todas atividades nela desenvolvidas; registro aerofotogramétrico temporal do local; levantamento do uso da água subterrânea; levantamento da geologia, pedologia e hidrogeologia; modelo conceitual inicial e outras informações que forem necessárias (CETESB, 2017).

Caso sejam detectados indícios de contaminação conforme o resultado da avaliação preliminar, a área passa ser classificada como suspeita de contaminação (AS) (figura 7), na qual é exigida a Investigação Confirmatória.

A etapa de Investigação Confirmatória tem como objetivo principal confirmar ou não a existência de contaminação na área em avaliação, por meio da investigação de todas as fontes potenciais e primárias de contaminação identificadas na etapa de Avaliação Preliminar, e como objetivo adicional a obtenção de dados iniciais necessários à caracterização do meio físico. Nessa etapa, por meio de parâmetros físico-químicos são 
coletadas e enviadas as amostras de solo, água subterrânea e gases para os laboratórios credenciados no Inmetro.

Figura 7- Área com Suspeita de Contaminação.

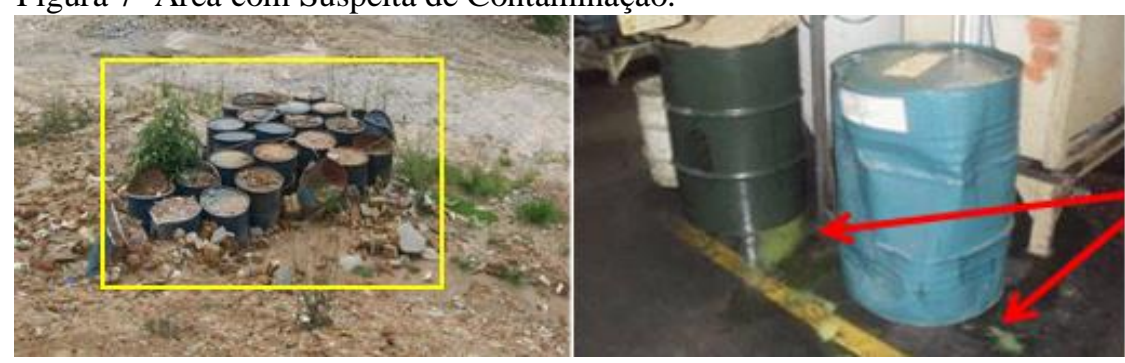

Extraído de: SVMA, 2016.

Os resultados obtidos das análises químicas das amostras deverão ser comparados com os Valores de Intervenção (VI) ${ }^{2}$ para solos e águas subterrâneas estabelecidos pela CETESB por meio da Decisão de Diretoria no 256/2016/E (CETESB, 2016).

A área será classificada como Área Contaminada sob Investigação (ACI), caso sejam constatadas uma ou mais das condições estabelecidas no artigo 28 do Decreto $n^{\circ}$ 59.263/2013, ou seja:

"I - Contaminantes no solo ou na água subterrânea em concentrações acima dos Valores de Intervenção;

II - Produto ou substância em fase livre;

III - Substâncias, condições ou situações que, de acordo com os parâmetros específicos, possam representar perigo, conforme artigo $19, \S 3^{\circ}$ deste decreto;

IV - Resíduos perigosos dispostos em desacordo com as normas vigentes" (SÃO PAULO (estado), 2013).

Posteriormente é necessário atualizar a ficha cadastral (banco de dados) alterando a classificação da área e o responsável legal deverá realizar Investigação Detalhada e a Avaliação de Risco.

A etapa de Investigação Detalhada configura-se em caracterizar o meio físico onde se insere a (ACI); determinar as concentrações das substâncias químicas de interesse nos diversos meios avaliados; definir tridimensionalmente os limites das plumas de contaminação; quantificar as massas das substâncias químicas de interesse, considerando as diferentes fases em que se encontram; caracterizar o transporte das substâncias químicas de interesse e sua evolução no tempo e caracterizar os cenários de exposição (figura 8) necessários à realização da etapa de Avaliação de Risco.

${ }^{2}$ É a concentração de determinada substância no solo ou na água subterrânea acima dos valores orientadores da qual existem riscos potenciais, diretos ou indiretos, à saúde humana, considerando um cenário de exposição padronizado (BRASIL, 2009). 
Figura 8- Simulação Hipotética: cenário de exposição.

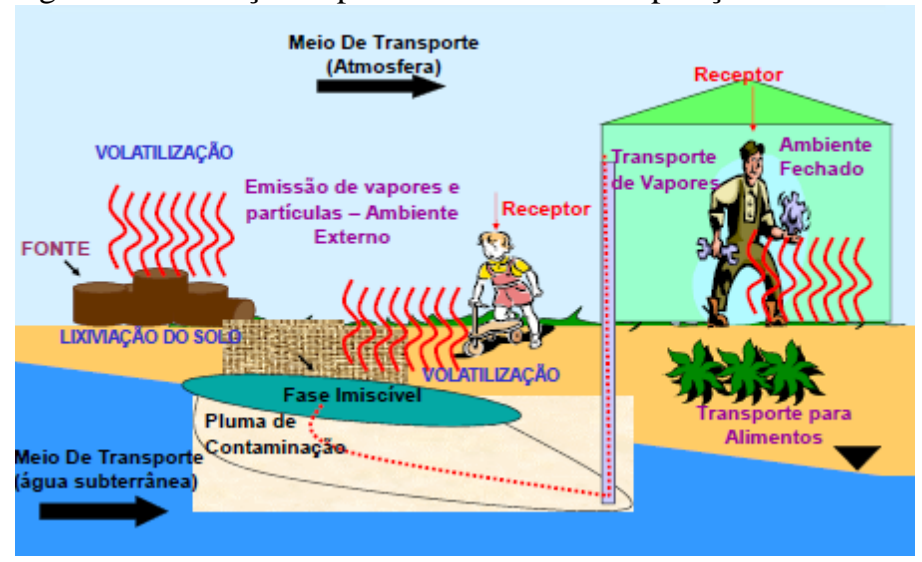

Extraído de: LEMOS, 2019.

O conceito de risco é definido como a probabilidade em que uma substância ou uma situação produziria um dano sob condições específicas. Já a análise de risco é compreendida como a probabilidade de ocorrência de efeito (s) adverso (s) em receptores humanos e organismos presentes no ecossistema expostos a contaminantes (SONG, 2004).

Logo, a avaliação de risco é o processo que visa caracterizar a existência de risco aos receptores identificados, expostos e potencialmente expostos às substâncias químicas de interesse presentes na Área Contaminada sob Investigação (ACI) e decidir sobre a necessidade de implementação de medidas de intervenção (CETESB, 2017).

SONG (2004) afirma que a meta do gerenciamento de risco é identificar ações integradas saudáveis e com boa relação de custo-benefício, que reduzam ou previnam os riscos levando em conta a prestação de contas social, cultural, ética, política e legais. Além disso, LEMOS (2019) destaca que para que exista a presença do risco é necessário, três componentes no ambiente:

- Agente químico- Produto químico ou substância existente na área que pode representar risco;

- Receptor- pessoa, organismo ou recurso que possa entrar em contato com o produto ou substância;

- Exposição- contato do organismo com o produto ou substâncias nos caminhos de exposição.

Desta forma, a Avaliação de Risco à Saúde Humana deverá ser desenvolvida considerando todas as informações geradas nas etapas anteriores, as orientações e normas técnicas nacionais e internacionais, além do uso da Planilha para Avaliação de Risco da 
CETESB. Para a Avaliação de Risco Ecológico deverá ser elaborada nas situações em que exista ecossistema natural sob influência ou que possam estar sob influência da ACI (CETESB, 2017).

Após a realização da etapa de Avaliação de Risco, não tendo sido verificada qualquer das situações indicadas no artigo 36 do Decreto $n^{\circ}$ 59.263/2013, a área será classificada como Área em Processo de Monitoramento para Encerramento (AME), devendo ser iniciada a etapa de Monitoramento para Encerramento.

Artigo 36 - A área será classificada como Área Contaminada com Risco Confirmado (ACRi) nas seguintes situações:

I - realizada a Avaliação de Risco foi constatado que os valores definidos para risco aceitável à saúde humana foram ultrapassados, considerando-se os níveis de risco definidos por meio de Resolução conjunta da Secretaria Estadual de Meio Ambiente e da Secretaria Estadual de Saúde, após ouvido o CONSEMA;

II - quando for observado risco inaceitável para organismos presentes nos ecossistemas, por meio da utilização de resultados de Avaliação de Risco Ecológico;

III - nas situações em que os contaminantes gerados em uma área tenham atingido compartimentos do meio físico e determinado a ultrapassagem dos padrões legais aplicáveis ao enquadramento dos corpos d'água e de potabilidade;

IV - nas situações em que os contaminantes gerados possam atingir corpos d'água superficiais ou subterrâneos, determinando a ultrapassagem dos padrões legais aplicáveis, comprovadas por modelagem do transporte dos contaminantes;

V - nas situações em que haja risco à saúde ou à vida em decorrência de exposição aguda a contaminantes, ou à segurança do patrimônio público ou privado (SÃ̃ PAULO (estado), 2013).

Entretanto, quando constatada a existência do risco a área será classificada como Área Contaminada com Risco Confirmado (ACRi), e com base no que determina no artigo 44 do Decreto $n^{\circ}$ 59.263/2013, deverá ser realizado o Plano de Intervenção, ilustrado no fluxograma da figura 9 .

A apresentação do Plano de Intervenção à CETESB deverá ocorrer para todas as áreas classificadas como Área Contaminada com Risco Confirmado (ACRi), ainda que sua aprovação prévia à implementação seja obrigatória apenas para os casos de reutilização e de áreas contaminadas críticas, como determinam os artigos 64 e 66 do Decreto n 59263/2013, respectivamente. 
Figura 9- Plano de Intervenção para Reutilização de Áreas Contaminadas.

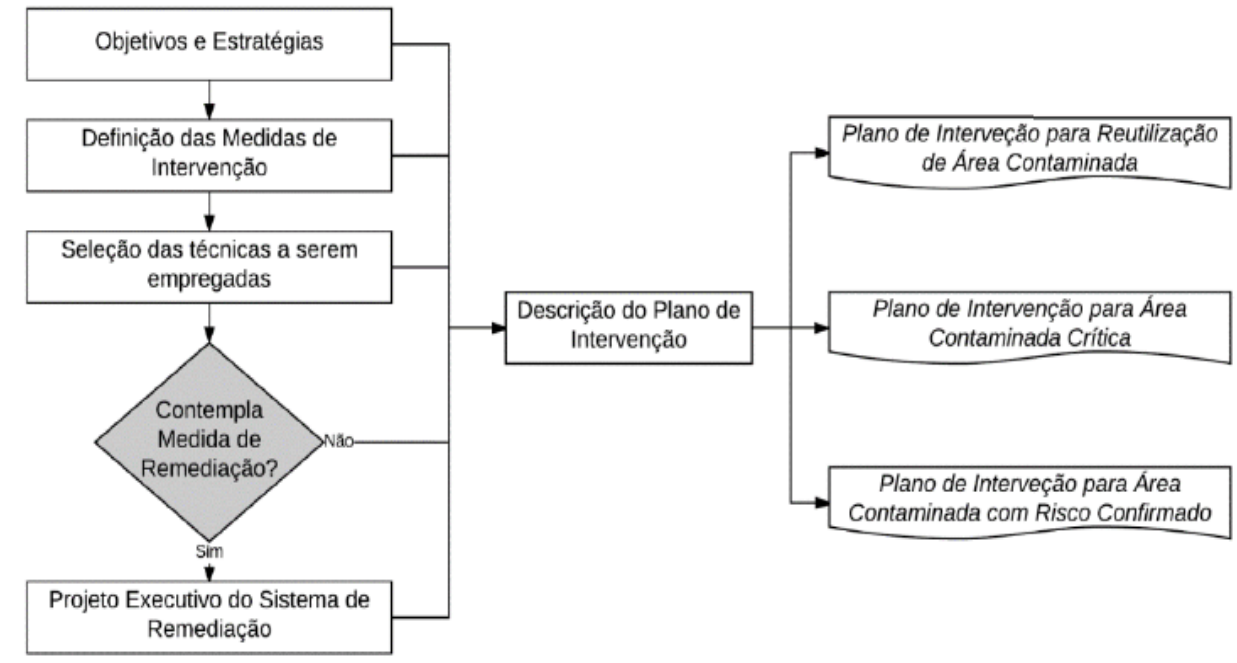

Extraído de: CETESB, 2017. p. 31.

Conforme $\S^{\circ}$ do artigo 44 do Decreto $n^{\circ} 59.263 / 2013$, no Plano de Intervenção poderão ser admitidas medidas de remediação para tratamento e para contenção, medidas de engenharia e medidas de controle institucional, que poderão ser propostas em conjunto ou isoladamente.

No caso de reutilização de áreas contaminadas, o Plano de Intervenção deverá ser submetido à aprovação da CETESB previamente à sua implantação, conforme artigo 64 do Decreto Estadual no 59.263/2013, sendo:

Artigo 64 - Nas áreas classificadas como Áreas Contaminadas sob Investigação (ACI) ou Área Contaminada com Risco Confirmado (ACRi), a CETESB deverá se manifestar acerca da possibilidade de edificação, baseando-se em Plano de Intervenção a ser elaborado como descrito na Seção III deste Regulamento.

$\S 1^{\circ}$ - A manifestação a que se refere o "caput" deste artigo se dará por meio de parecer técnico.

$\S 2^{\circ}$ - Aprovado o Plano de Intervenção, a área será classificada como Área Contaminada em Processo de Reutilização (ACRu).

$\S 3^{\circ}$ - Caso o Plano de Intervenção apresentado pelo responsável legal seja aprovado, o responsável legal deverá apresentar o parecer técnico emitido pela CETESB aos órgãos municipais competentes para a emissão das devidas autorizações para demolição e construção.

$\S 4^{\circ}$ - No Plano de Intervenção serão admitidas propostas que contemplem a implantação e a operação de medidas de remediação e de medidas de engenharia, concomitante à execução das obras civis, desde que adotadas medidas de proteção aos trabalhadores.

$\S 5^{\circ}$ - Os órgãos municipais competentes poderão emitir as autorizações para a utilização da área, após a CETESB atestar, por meio da emissão de Termo de Reabilitação para o Uso Declarado, o cumprimento das medidas propostas no Plano de Intervenção aprovado.

$\S 6^{\circ}$ - A CETESB definirá por meio de Decisão de Diretoria o preço para a emissão de parecer técnico relativo à análise do Plano de Intervenção, destinando os recursos obtidos para o FEPRAC (SÃO PAULO (estado), 2013). 
Em seguida, tendo sido aprovado o Plano de Intervenção para Reutilização de Área Contaminada, a área será classificada como Área Contaminada em Processo de Reutilização $(\mathrm{ACRu})$.

Dando continuidade, após a execução do Plano de Intervenção caso tenham sido atingidas as metas de remediação e implementadas as medidas de controle institucional e de engenharia, quando propostas no Plano de Intervenção, a CETESB classificará a área como Área em Processo de Monitoramento para Encerramento (AME), conforme artigo 52 do Decreto $n^{\circ}$ 59.263/2013 (CETESB, 2017).

Posteriormente, conforme o artigo 53 do Decreto Estadual n ${ }^{\circ} 59.263 / 2013$ encerrado o período de monitoramento e mantidas as concentrações dos contaminantes abaixo das metas de remediação, a área será classificada como Área Reabilitada para o Uso Declarado (AR).

$\S 1^{\circ}$ - Nesta situação o responsável legal deverá solicitar à CETESB a emissão do Termo de Reabilitação para o Uso Declarado.

$\S 2^{\circ}$ - Nos casos em que a situação de risco aceitável estiver mantida por força de medidas de controle institucional ou de engenharia, a eficácia dessas medidas deverá ser avaliada por todo o período em que forem necessárias (SÃO PAULO (estado), 2013).

Entretanto, para a alteração do uso ou ocupação de uma Área Reabilitada para o Uso Declarado (AR), deverá ser efetuada nova Avaliação de Risco para o uso pretendido, a qual será submetida pelo responsável legal à aprovação da CETESB.

Parágrafo único - O novo uso autorizado para a Área Reabilitada para o Uso Declarado (AR) deverá atender à legislação de uso e ocupação do solo e será averbado pelo Cartório de Registro de Imóveis, mediante solicitação do responsável legal da área, nos termos do artigo 54, inciso II, deste decreto (Art. 55, SÃO PAULO (estado), 2013).

\subsection{LEGISLAÇÕES, NORMAS E POLÍTICAS PÚBLICAS SOBRE ÁREAS CONTAMINADAS}

O solo como bem ambiental vem paulatinamente sendo protegido pela legislação, sendo o estado de São Paulo o pioneiro em políticas públicas, em gerir e gerenciar as áreas contaminadas. 
A Cetesb, iniciou as ações corretivas sobre áreas contaminadas partir da década de 1980, que até então eram definidas e baseadas em metodologias estrangeiras, obtidas em literatura internacional.

Na década de 1990, com a evolução crescente de casos de áreas contaminadas no estado, o órgão ambiental se empenhou no aperfeiçoamento da metodologia do gerenciamento de áreas contaminadas, se tornando pioneiro e referencial em todo território nacional (SPÍNOLA et al. 2014).

Em 1993, foi feita uma cooperação com o governo da Alemanha por meio da Agência Técnica do Ministério de Ciência e Tecnologia GTZ (Gesellschaft für Technische Zusammenarbeit). Segundo CUNHA (1997), foi possível elaborar um conjunto de procedimentos que contemplou as etapas do processo de gerenciamento de áreas contaminadas, incentivando a criação do primeiro cadastro de áreas contaminadas do país.

Posteriormente, a agência ambiental publicou o Manual de Gerenciamento de Áreas Contaminadas também pioneiro no país, com sua aprovação, atualização e primeiros procedimentos para o gerenciamento, no ano de 2000 (CETESB, 2001).

Nesse manual também foram apresentados todos os direcionamentos para situações de contaminações por combustíveis decorrentes de vazamentos em postos de serviços e outros empreendimentos (CETESB, 2001; SPÍNOLA et al. 2014). Após passar por procedimentos foram revisados, atualizados e detalhados, e atualmente está em vigor a Decisão de Diretoria $\mathrm{n}^{\circ}$ 038/2017/C, a qual apresenta detalhes de cada etapa do gerenciamento.

Em 2001, a CETESB publicou a primeira lista de valores orientadores para Solos e Águas Subterrâneas para o Estado de São Paulo e o Relatório de Estabelecimento de Valores Orientadores para Solos e Águas Subterrâneas no Estado de São Paulo. De lá para cá, lista passou por atualizações, sendo atualmente vigente a estabelecida na DD nº 256/2016/E.

De modo geral, a Cetesb vem de forma contínua, buscando o aperfeiçoamento dos procedimentos de atuação no gerenciamento de áreas contaminadas. Diversos documentos e normas tratam de conceitos, princípios, objetivos, instrumentos e obrigações sobre à proteção dos compartimentos ambientais.

\subsubsection{Legislação Federal}

Diversas legislações foram aprovadas no âmbito federal, antes mesmo de se conhecer os impactos que as áreas contaminadas ocasionam no espaço urbano e à saúde da população. 
Essas legislações tratam de temas ambientais relacionados à questão do solo e sua poluição, que de certa forma, está diretamente ligado com as áreas contaminadas. Cabe destacar que comparado aos compartimentos ambientais ar e água, o conceito de importância da proteção, prevenção e recuperação da qualidade do solo foi o último a ser abordado.

A Lei Federal N. 1.413/1975 foi a primeira aprovada, no qual dispõe sobre o controle da poluição do meio ambiente provocada por atividades industriais. Essa lei evidencia que as indústrias instaladas ou a se instalarem são obrigadas a promover as medidas necessárias para prevenir ou corrigir os inconvenientes e prejuízos da poluição e da contaminação do meio ambiente (Art. 1, BRASIL, 1975).

Posteriormente teve-se a aprovação da Lei Federal N. 6.766/1979, que dispõe sobre o parcelamento do solo e dá outras providências. Entre as proibições, a lei destaca que não é permitido o parcelamento do solo em terrenos que tenham sido aterrados com material nocivo à saúde pública, sem que sejam previamente saneados (Art. 3-. II, BRASIL, 1979).

Entretanto fica evidente que essa proibição legal, não evitou posteriormente o surgimento de casos conhecidos como Barão de Mauá, Mansões de Santo Antônio, em que edifícios residenciais foram construídos em áreas contaminadas pela disposição irregular de resíduos (SPÍNOLA et al. 2014).

Posteriormente teve-se a Lei Federal N. 6.938/1981, conhecida como Política Nacional do Meio Ambiente (PNMA), com seus fins e mecanismos de formulação e aplicação, e dá outras providências. Nessa lei, ficaram definidos os termos como preservação, degradação e poluição, e também foi enfatizada a importância da recuperação de áreas degradadas e recuperação da qualidade ambiental, ou seja, recuperar aquilo que foi alterado (BRASIL, 1981; SPÍNOLA et al. 2014). Desta forma, ficou estabelecido que o poluidor tem por obrigação reparar ou indenizar o dano causado, ainda que não se saiba exatamente como, ou por qual meio, será realizado (Art.4.- VII, BRASIL, 1981).

De modo geral, a PNMA já demonstrava a importância da proteção e recuperação ambiental:

Art. 2- A Política Nacional do Meio Ambiente tem por objetivo a preservação, melhoria e recuperação da qualidade ambiental propícia à vida, visando assegurar, no País, condições ao desenvolvimento socioeconômico, aos interesses da segurança nacional e à proteção da dignidade da vida humana (BRASIL, 1981). 
Assim como já enfatizava a responsabilidade pela penalidade para os casos de poluição, como descreve o Art. 14, IV, § $1^{\circ}$ :

O poluidor é obrigado, independentemente da existência de culpa, a indenizar ou reparar os danos causados ao meio ambiente e a terceiros, afetados por sua atividade (BRASIL, 1981).

Mas, foi por meio da Lei federal N. 9.605/1998 conhecida pela Lei de Crimes Ambientais, que se conseguiu destacar de maneira importantíssima no âmbito ambiental, as condutas puníveis para crime de poluição ambiental. A partir de então, contaminar ou poluir um terreno passou a ser crime ambiental cabível de pena, independentemente do nível do dano causado à saúde humana (SPÍNOLA et al. 2014).

O Art. 54, $\S 2^{\circ}$ da referida lei, destaca que a punição de reclusão pode ser de um a cinco anos, se o crime:

I - tornar uma área, urbana ou rural, imprópria para a ocupação humana;

II- causar poluição atmosférica que provoque a retirada, ainda que momentânea, dos habitantes das áreas afetadas, ou que cause danos diretos à saúde da população;

III- causar poluição hídrica que torne necessária a interrupção do abastecimento público de água de uma comunidade;

IV - dificultar ou impedir o uso público das praias;

V - ocorrer por lançamento de resíduos sólidos, líquidos ou gasosos, ou detritos, óleos ou substâncias oleosas, em desacordo com as exigências estabelecidas em leis ou regulamentos (BRASIL, 1998).

De maneira geral, a lei enfatiza que causar poluição de qualquer natureza em níveis que resultem em danos à saúde humana, mortandade de animais ou destruição significativa da flora é cabível de reclusão, multa ou detenção (BRASIL, 1998).

Com intuito de apoiar e fixar as infrações administrativas quanto a causar poluição ambiental, foi promulgado o Decreto Federal N.9605/1998 revogado pelo Decreto Federal N. 6.514/2008, aplicável às áreas contaminadas. Esse decreto dispõe sobre as infrações e sanções administrativas ao meio ambiente, no qual estabelece o processo administrativo federal para apuração destas infrações, e dá outras providências (BRASIL, 2008).

Desta forma, mesmo com todas normas vigentes e sendo um instrumento importantíssimo quanto à poluição do solo, a primeira resolução aprovada que passou abordar o tema de áreas contaminadas foi a Resolução Conama N. 273/2000.

Essa resolução estabeleceu as diretrizes para o licenciamento ambiental de postos de combustíveis e serviços sobre a prevenção e controle da poluição. Também foi nesta resolução, que se destacou que acidentes ou vazamentos de combustíveis representam 
situações de perigo ao meio ambiente ou a pessoa humana, podendo causar contaminação de corpos d'água subterrâneos e superficiais, do solo e do ar (BRASIL, 2000).

Entretanto, SPÍNOLA et al. (2014), destacam que foi a partir do ano de 2006, que a legislação ambiental passou a se especializar no tema, reconhecendo a existências das áreas contaminadas e buscando conhecer os procedimentos necessários para gerenciá-las.

Esse reconhecimento foi possível porque as áreas contaminadas foram inseridas na legislação ambiental por meio da Resolução Conama n.420/2009, que determinou aos estados o prazo de quatro anos para estabelecer seus valores próprios de referência de qualidade de solo (BRASIL, 2009).

Esses referidos valores orientadores auxiliam na manutenção da qualidade do solo, assim como das águas subterrâneas, servindo como parâmetro para gerenciar áreas contaminadas e prevenir riscos à saúde humana e ao meio ambiente (BRASIL, 2009; SPÍNOLA, et al. 2014). Importante destacar que os estados brasileiros que ainda não possuem uma política pública específica para as áreas contaminadas, devem utilizar e seguir como parâmetro essa resolução.

Além disso, a Política Nacional Resíduos Sólidos- PNRS, pela Lei Federal N. 12.305/2010 também aborda áreas contaminadas. Um fato importante a ser destacado nessa lei, é que o poder público poderá instituir medidas indutoras e linhas de financiamento para atender, prioritariamente, às iniciativas de descontaminação de áreas contaminadas, incluindo as áreas órfãs (BRASIL, 2010).

O quadro 3 apresenta resumidamente todas as leis no âmbito federal que estão relacionadas indiretamente e diretamente com áreas contaminadas.

Quadro 3- Legislações Federais.

\begin{tabular}{|c|l|}
\hline Legislação Ambiental & \multicolumn{1}{c|}{ Descrição da Legislação } \\
\hline $\begin{array}{c}\text { Lei Federal } \\
N^{0} 1.413 / 1975\end{array}$ & $\begin{array}{l}\text { Dispõe sobre o controle da poluição do meio } \\
\text { ambiente provocada por atividades industriais. }\end{array}$ \\
\hline $\begin{array}{c}\text { Lei Federal } \\
N^{\circ} 6.766 / 1979\end{array}$ & $\begin{array}{l}\text { Dispõe sobre o Parcelamento do Solo Urbano e } \\
\text { dá outras Providências. }\end{array}$ \\
\hline Lei Federal & $\begin{array}{l}\text { Dispõe sobre a Política Nacional do Meio } \\
\text { Ambiente, seus fins e mecanismos de formulação } \\
\text { e aplicação, e dá outras providências. }\end{array}$ \\
\hline Lei Federal $6.938 / 1981$ & $\begin{array}{l}\text { Dispõe sobre as sanções penais e administrativas } \\
\text { derivadas de condutas e atividades lesivas ao } \\
\text { meio ambiente, e dá outras providências. }\end{array}$ \\
$\mathrm{N}^{\mathrm{o}} 9.605 / 1998$ & $\begin{array}{l}\text { Estabelece diretrizes para o licenciamento } \\
\text { ambiental de postos de combustíveis e serviços e } \\
\text { dispõe sobre a prevenção e controle da poluição. }\end{array}$ \\
\hline
\end{tabular}

Continua... 


\begin{tabular}{|c|l|}
\hline $\begin{array}{c}\text { Decreto Federal } \\
N^{\circ} 9605 / 1998 \text { revogado } \\
\text { pelo Decreto Federal } \\
N^{\circ} 6.514 / 2008 .\end{array}$ & $\begin{array}{l}\text { Dispõe sobre as infrações e sanções } \\
\text { administrativas ao meio ambiente, estabelece o } \\
\text { processo administrativo federal para apuração } \\
\text { destas infrações, e dá outras providências. }\end{array}$ \\
\hline $\begin{array}{c}\text { Resolução Conama } \\
N^{0} 420 / 2009\end{array}$ & $\begin{array}{l}\text { Dispõe sobre critérios e valores orientadores de } \\
\text { qualidade do solo quanto à presença de } \\
\text { substâncias químicas e estabelece diretrizes para } \\
\text { o gerenciamento ambiental de áreas contaminadas } \\
\text { por essas substâncias em decorrência de } \\
\text { atividades antrópicas. }\end{array}$ \\
\hline Lei No 12.305/2010 & $\begin{array}{l}\text { Institui a Política Nacional de Resíduos Sólidos; } \\
\text { altera a Lei no 9.605, de 12 de fevereiro de 1998; } \\
\text { e dá outras providências. }\end{array}$ \\
\hline
\end{tabular}

Extraído de: SPÍNOLA et al. 2014; CANÁRIO, 2018. Elaborado pela autora.

\subsubsection{Legislação Estadual}

No contexto estadual também há várias legislações e normas ambientais que estão relacionadas com as áreas contaminadas.

Em 1976, o estado de São Paulo aprovou a Lei N.997/1976 e seu regulamento aprovado pelo Decreto N. 8.648/1976, que dispõe sobre o controle da poluição do meio ambiente.

Sob o aspecto legal, a legislação enfatiza que é proibido o lançamento ou liberação de poluentes nas águas, no ar ou no solo. Tal fato chama a atenção, pois nessa época o solo era considerado receptor ilimitado principalmente de resíduo sólido. Segundo a legislação não era permitido depositar, dispor, descarregar, enterrar, infiltrar ou acumular no solo resíduos ou em qualquer estado de matéria (SÃO PAULO (estado), art. 51, 1976). Para tanto, a legislação referida, destaca ainda que:

Art. 52 - O solo somente poderá ser utilizado para destino final de resíduos de qualquer natureza, desde que sua disposição seja feita de forma adequada, estabelecida em projetos específicos de transporte e destino final, ficando vedada a simples descarga ou depósito, seja em propriedade pública ou particular (SÃO PAULO (estado), 1976).

Já no ano de 1997, com a aprovação da Lei N.9509/1997, que dispõe sobre a Política Estadual do Meio Ambiente de São Paulo, ficou destacada a questão do desenvolvimento econômico social, a preservação da qualidade do meio ambiente, do equilíbrio ecológico e 
da fiscalização e controle das atividades capazes de provocar degradação ambiental (SÃO PAULO (estado), 1997).

Foi através do Decreto N. 47.400/2002, que regulamenta dispositivos da Lei Estadual $\mathrm{n}^{\mathrm{o}} 9.509 / 1997$, onde se exigiu que os empreendimentos sujeitos ao licenciamento ambiental que tivessem suas atividades encerradas ou suspensas, deveriam apresentar um plano de desativação, contemplando a situação ambiental existente do local (SÃO PAULO (estado), 2002).

Ainda sobre o referido Decreto, ressalta que se for o caso o responsável, deve informar a implementação das medidas de restauração e de recuperação da qualidade ambiental das áreas que serão desativadas ou desocupadas (SÃO PAULO (estado), 2002).

Nesse contexto, em 2009 a lei paulista N. 13.577/2009, bem como seu Decreto regulamentador N. 59.263/2013, por sua vez, foi a primeira e única lei específica aprovada no país de proteção da qualidade do solo e gerenciamento de áreas contaminadas.

Entre os assuntos específicos abordados de áreas contaminadas encontram-se: as definições de termos técnicos; o enquadramento da classificação das áreas; a definição das responsabilidades legais; a identificação e o cadastramento de áreas contaminadas; a descrição dos procedimentos legais quanto ao gerenciamento; as competências dos órgãos públicos envolvidos; a criação do Fundo Estadual para Prevenção e Remediação de Áreas Contaminadas (FEPRAC), de forma a tornar seguros seus usos atual e futuro (SÃO PAULO (estado), 2009; SPÍNOLA et al. 2014).

Ainda no corpo da legislação estadual se têm duas resoluções da Secretaria de Estado de Meio Ambiente (SMA).

A Resolução SMA 10/2017, aborda a definição das atividades potencialmente geradoras de áreas contaminadas, apresentando um código específico para cada fonte, conforme a Classificação Nacional de Atividades Econômicas- CNAE (SÃO PAULO (estado), 2017). E a Resolução SMA 11/2017, define as regiões prioritárias para a identificação de áreas contaminadas e estabelece que os empreendimentos nessas regiões cujas atividades se enquadrem na Resolução SMA 10/2017, deverão realizar Avaliação Preliminar e Investigação Confirmatória (SÃO PAULO (estado), 2017a).

Ainda nesse contexto há outros documentos e normas de grande importância que são constantemente utilizados em conjunto com as respectivas legislações, listadas no quadro 4.

Cabe lembrar, que esses documentos são constantemente atualizados e sofrem pequenas alterações, como por exemplo, as nomenclaturas das etapas e classificações, não 
sendo alterada de forma significativa a estrutura básica do gerenciamento de áreas contaminadas (SPÍNOLA et al. 2014).

Quadro 4- Legislações Estaduais, Normas e Documentos.

\begin{tabular}{|c|c|}
\hline Legislação e Resolução & Descrição \\
\hline Lei Estadual $N^{\circ} 997 / 1976$ & $\begin{array}{l}\text { Dispõe sobre o controle da poluição do meio } \\
\text { ambiente. }\end{array}$ \\
\hline Lei Estadual $\mathrm{N}^{\circ}$ 9.509/1997 & $\begin{array}{l}\text { Dispõe sobre a Política Estadual do Meio Ambiente, } \\
\text { seus fins e mecanismos de formulação e aplicação. }\end{array}$ \\
\hline Decreto $\mathrm{N}^{\circ} 47.400 / 2002$ & $\begin{array}{l}\text { Regulamenta dispositivos da Lei Estadual n. }{ }^{\circ} 9.509 \text {, } \\
\text { de } 20 \text { de março de } 1997 \text {, referentes ao licenciamento } \\
\text { ambiental, estabelece prazos de validade para cada } \\
\text { modalidade de licenciamento ambiental e condições } \\
\text { para sua renovação, estabelece prazo de análise dos } \\
\text { requerimentos e licenciamento ambiental, institui } \\
\text { procedimento obrigatório de notificação de } \\
\text { suspensão ou encerramento de atividade, e o } \\
\text { recolhimento de valor referente ao preço de análise. }\end{array}$ \\
\hline $\begin{array}{c}\text { Lei Estadual } N^{\circ} 13.577 / 2009 \text { regulamentado } \\
\text { pelo Decreto } N^{\circ} 59.263 / 2013\end{array}$ & $\begin{array}{l}\text { Dispõe sobre diretrizes e procedimentos para a } \\
\text { proteção da qualidade do solo e gerenciamento de } \\
\text { áreas contaminadas, e dá outras providências } \\
\text { correlatas. }\end{array}$ \\
\hline Resolução SMA 10/2017 & $\begin{array}{l}\text { Dispõe sobre a definição das atividades } \\
\text { potencialmente geradoras de áreas contaminadas. }\end{array}$ \\
\hline Resolução SMA 11/2017 & $\begin{array}{l}\text { Dispõe sobre a definição das regiões prioritárias para } \\
\text { a identificação de áreas contaminadas. }\end{array}$ \\
\hline Documentos da CETESB & Descrição \\
\hline $\begin{array}{l}\text { Manual de Gerenciamento de Áreas } \\
\text { Contaminadas- CETESB/GTZ, 2001. } \\
\text { (2ed, última versão) }\end{array}$ & $\begin{array}{l}\text { Projeto específico dentro do tema de Áreas } \\
\text { Contaminadas com o objetivo de capacitar a } \\
\text { instituição para sua atuação no gerenciamento dessas } \\
\text { áreas. Parceria com a Cooperação Técnica (Deutsche } \\
\text { Gesellschaft für Technische Zusammenarbeit, GTZ). }\end{array}$ \\
\hline $\begin{array}{l}\text { Guia para Avaliação Potencial de } \\
\text { Contaminação em Imóveis, } 2003 .\end{array}$ & $\begin{array}{l}\text { Guia é uma metodologia para identificar indícios de } \\
\text { contaminação em imóveis que receberão novos } \\
\text { empreendimentos. }\end{array}$ \\
\hline Decisão de Diretoria No 263/2009/P & $\begin{array}{l}\text { Dispõe sobre a aprovação do Roteiro para Execução } \\
\text { de Investigação Detalhada e Elaboração de Plano de } \\
\text { Intervenção em Postos e Sistemas Retalhistas de } \\
\text { Combustíveis. }\end{array}$ \\
\hline Decisão de Diretoria DD Nº 256/2016/E. & $\begin{array}{l}\text { Dispõe sobre os Valores Orientadores para solo e } \\
\text { água subterrânea no estado de São Paulo. }\end{array}$ \\
\hline Decisão de Diretoria No $038 / 2017 / C$ & $\begin{array}{l}\text { Dispõe sobre a aprovação do "Procedimento para a } \\
\text { Proteção da Qualidade do Solo e das Águas } \\
\text { Subterrâneas", da revisão do "Procedimento para o } \\
\text { Gerenciamento de Áreas Contaminadas" e estabelece } \\
\text { "Diretrizes para Gerenciamento de Áreas } \\
\text { Contaminadas no Âmbito do Licenciamento } \\
\text { Ambiental", em função da publicação da Lei } \\
\text { Estadual no } 13.577 / 2009 \text { e seu Regulamento, } \\
\text { aprovado por meio do Decreto n' } 59.263 / 2013 \text {, e dá } \\
\text { outras providências. }\end{array}$ \\
\hline
\end{tabular}

Continua... 


\begin{tabular}{|c|c|}
\hline Instrumentação Técnica No 39/2017 & $\begin{array}{l}\text { São apresentados os trâmites administrativos e as } \\
\text { atribuições referentes à aplicação do Procedimento } \\
\text { para a Proteção da Qualidade do Solo e das Águas } \\
\text { Subterrâneas, Procedimento para Gerenciamento de } \\
\text { Áreas Contaminadas e Diretrizes para o } \\
\text { Gerenciamento de Áreas Contaminadas no Âmbito } \\
\text { do Licenciamento Ambiental, aprovados por meio da } \\
\text { Decisão de Diretoria no 038/2017/C, de 07 de } \\
\text { fevereiro de 2017, publicada no Diário Oficial do } \\
\text { Estado de São Paulo em } 10 \text { de fevereiro de } 2017 \text {, } \\
\text { elaborada em cumprimento ao Decreto n } \\
59.263 / 2013 \text {, que aprova o Regulamento da Lei n } \\
\text { 13.577/2009. }\end{array}$ \\
\hline Normas ABNT & Descrição \\
\hline $\begin{array}{l}\text { ABNT NBR 15515-1:2007 } \\
\text { Versão Corrigida: } 2011 .\end{array}$ & $\begin{array}{l}\text { Passivo Ambiental em solo e água subterrânea Parte } \\
\text { 1: Avaliação Preliminar. }\end{array}$ \\
\hline ABNT NBR 15515-2: 2011 & $\begin{array}{l}\text { Passivo Ambiental em solo e água subterrânea Parte } \\
\text { 2: Investigação Confirmatória. }\end{array}$ \\
\hline ABNT NBR 15515-3: 2013 & $\begin{array}{l}\text { Avaliação de passivo ambiental em solo e água } \\
\text { subterrânea Parte 3- Investigação detalhada. }\end{array}$ \\
\hline ABNT NBR 16209: 2013 & $\begin{array}{l}\text { Avaliação de risco a saúde humana para fins de } \\
\text { gerenciamento de áreas contaminadas. }\end{array}$ \\
\hline ABNT NBR 16210: 2013 & $\begin{array}{l}\text { Modelo conceitual no gerenciamento de áreas } \\
\text { contaminadas- procedimento. }\end{array}$ \\
\hline
\end{tabular}

Extraído de: SPÍNOLA et al. 2014; CANÁRIO, 2018. Elaborado pela autora.

\subsubsection{Legislação Municipal}

$\mathrm{O}$ gerenciamento de áreas contaminadas é realizado, conforme Decreto Municipal $\mathrm{n}^{\circ}$ 58.265/2019, pela Secretaria do Verde e do Meio Ambiente do Município de São PauloCoordenação de Licenciamento Ambiental, através do Grupo Técnico de Áreas Contaminadas- GTAC, instituído em 2002, mediante a Portaria 97/SVMA-G/2002, atualizada pela Portaria 004/DECONT-G/2015.

O GTAC realiza, o gerenciamento das áreas contaminadas em cumprimento aos $\operatorname{artigos} 37^{\circ}$ e $137^{\circ}$ da Lei Municipal $n^{\circ} 16.402 / 2016$. Além disso, mantém atualizado o cadastro de áreas contaminadas compatibilizando-o com bancos de dados existentes em consonância com o órgão ambiental estadual (CETESB), publicando o Relatório de Áreas Contaminadas no site eletrônico da Prefeitura, como exige a Lei 15.098/2010 (SÃO PAULO (cidade), 2010; SVMA, 2019a).

Também é importante ressaltar que no relatório deverão constar obrigatoriamente todas as áreas públicas e privadas cujos procedimentos de avaliação e eventual descontaminação sejam gerenciados pela SVMA e publicados trimestralmente, conforme o Decreto No 51.436/2010 (SÃO PAULO (cidade), 2010a). 
A Lei $n^{\circ}$ 16.402/2016 refere-se sobre disciplina do parcelamento, o uso e a ocupação do solo no Município de São Paulo, de acordo com a Lei n ${ }^{\circ} 16.050$, de 31 de julho de 2014Plano Diretor Estratégico (PDE).

No Art. 37 é determinada a condição na qual não será permitido o parcelamento do solo nas seguintes situações de áreas contaminadas, sendo:

I- em terrenos alagadiços e sujeitos a inundações, antes de tomadas as providências para assegurar o escoamento das águas;

II- em áreas com potencial ou suspeitas de contaminação, em áreas contaminadas e em monitoramento ambiental, sem que haja manifestação favorável do órgão ambiental competente para sua reutilização conforme o uso pretendido;

III- em terrenos com declividade igual ou superior a $30 \%$ (trinta por cento), salvo se atendidas as exigências específicas das autoridades competentes;

IV- em terrenos onde a incidência de processos geológico-geotécnicos não aconselhe a edificação;

V- em áreas de preservação ecológica;

VI - em áreas onde a poluição, em suas diversas formas, impeça condições sanitárias suportáveis, até a sua correção (SÃO PAULO (cidade), 2016).

Contudo, no art. 137 consta:

A emissão de alvarás, licenças de funcionamento ou suspensão de atividades enquadradas no licenciamento ambiental municipal, certificados de conclusão e outras situações específicas referentes ao uso e à ocupação do solo em áreas públicas ou privadas consideradas potencialmente contaminadas, suspeitas de contaminação, contaminadas ou em monitoramento ambiental, fica condicionada à manifestação favorável do órgão ambiental competente, respeitada a legislação aplicável em vigor (SÃO PAULO (cidade), 2016).

Existem outros instrumentos de planejamento e gestão urbana ambiental que a SVMA utiliza e emprega no gerenciamento de áreas contaminadas, apresentados no quadro 5. Cabe lembrar que a SVMA também utiliza legislações, documentos e as normas dos âmbitos federal e estadual, citadas anteriormente.

Quadro 5- Legislações Municipais de São Paulo.

\begin{tabular}{|c|c|}
\hline Legislação Ambiental & Descrição da Legislação \\
\hline Lei $N^{\circ} 15.098 / 2010$ & $\begin{array}{l}\text { Obriga o poder executivo municipal a publicar na } \\
\text { imprensa oficial ou disponibilizar no site oficial da } \\
\text { Prefeitura Relatório das Áreas Contaminadas do } \\
\text { Município de São Paulo. }\end{array}$ \\
\hline
\end{tabular}




\begin{tabular}{|c|l|}
\hline Lei N ${ }^{\circ} 16.402 / 2016$ & $\begin{array}{l}\text { Estabelece normas complementares ao Plano } \\
\text { Diretor Estratégico, institui os Planos Regionais } \\
\text { Estratégicos das Subprefeituras, dispõe sobre o } \\
\text { parcelamento, disciplina e ordena o uso e ocupação } \\
\text { do solo do município de São Paulo. }\end{array}$ \\
\hline Decreto No 51.436/2010 & $\begin{array}{l}\text { Regulamenta a Lei N } N^{\circ} 15.098 / 2010, \text { que obriga o } \\
\text { Poder Executivo a publicar na Imprensa Oficial ou } \\
\text { disponibilizar no site oficial da Prefeitura Relatório } \\
\text { das Áreas Contaminadas do Município de São } \\
\text { Paulo. }\end{array}$ \\
\hline Lei $\mathrm{N}^{\circ} 16.050 .2014$ & $\begin{array}{l}\text { Aprova a Política de Desenvolvimento Urbano e o } \\
\text { Plano Diretor Estratégico do Município de São } \\
\text { Paulo e revoga a Lei n }{ }^{\circ} 13.430 / 2002 .\end{array}$ \\
\hline
\end{tabular}

Extraído de: SPÍNOLA, 2011; SVMA, 2019a. Elaborado pela autora.

Como descrito, esses são os órgãos ambientais responsáveis pelas áreas contaminadas em São Paulo e suas respectivas legislações, ficando sob sua responsabilidade o controle e a fiscalização das áreas contaminadas no território urbano, assim como seu processo de reabilitação.

\subsection{RESÍDUOS SÓLIDOS URBANOS}

\subsubsection{Panorama Internacional: da geração à disposição no solo}

Mundialmente nos últimos tempos, os resíduos sólidos domésticos denominados também de resíduos sólidos urbanos (RSU) são os principais responsáveis pelo aumento exponencial das grandes quantidades geradas, apresentando um grande desafio para as administrações públicas.

No Brasil, de acordo com a Lei 12.305/2010 que institui a Política Nacional de Resíduos Sólidos- PNRS, define RSU como: “aqueles originários das atividades domésticas em regiões urbanas e das atividades de varrição, limpeza de logradouros e de vias públicas” (BRASIL, 2010).

No ano de 2012, o Worldwatch Institute destacou que o consumo de bens industrializados tenderia a dobrar o volume anual de RSU até 2025 no âmbito globalpassando de 1,3 bilhões de toneladas para 2,6 de toneladas por ano, desafiando a gestão ambiental e de saúde pública das cidades do mundo (WORLDWATCH INSTITUTE, 2012). 
Nos Estados Unidos no ano de 2015, foi identificado que cerca de 94\% dos RSU gerados- 37,6 mil toneladas foram de resíduos orgânicos enviados para os aterros sanitários, gerando mais impostos ambientais, além de consumir mais recursos naturais e impactar a biodiversidade (USEPA, 2017).

Nos países mais ricos como Austrália, Alemanha, França e Suécia é esperado que a quantidade gerada de RSU aumente cerca de 1,6 milhões de toneladas por dia, correspondendo mais de 2 quilos/dia. Em contraste, têm-se a África Subsaariana que produz menos de um oitavo, correspondendo a cerca de 200.000 toneladas por dia, e o sul da Ásia, em que a taxa é inferior a um quarto, menos de meio quilo por pessoa (WORLDWATCH INSTITUTE, 2012; OECD, 2019).

Segundo os dados do World Bank (WB, 2018), o atual nível global de geração de RSU é de 2,01 bilhões de toneladas por ano e deverá aumentar para cerca de 3,40 bilhões de toneladas por ano até 2050. Além do expressivo crescimento da geração desses resíduos, observam-se ainda, ao longo dos últimos anos, mudanças significativas em sua composição e características e o aumento de sua periculosidade.

Essas mudanças segundo (JACOBI; BESEN, 2011) decorrem dos modelos de desenvolvimento pautados pela obsolescência programada dos produtos, pela descartabilidade e pela mudança nos padrões baseados no consumo excessivo e supérfluo. Outro fator vinculado é o crescimento e a longevidade da população aliados à intensa urbanização e à expansão do consumo de novas tecnologias acarretando na produção de imensas quantidades de resíduos.

Para tal cenário, a Organização das Nações Unidas- ONU no relatório da Agenda 2030, determinou que até 2030 é necessário reduzir substancialmente a geração dos resíduos sólidos por meio da prevenção, redução, reciclagem e reuso (ONU, 2015. p. 31).

Desse modo, as autoridades governamentais estão cada vez mais reconhecendo os riscos e custos significativos dos aterros sanitários, visando buscar métodos sustentáveis de eliminação e de consumo consciente dos resíduos sólidos.

Das práticas de descarte, a disposição de resíduos sólidos em aterros sanitários em todo o mundo, ainda é a mais realizada com quase $40 \%$. Cerca de $19 \%$ passam por valorização por meio de reciclagem e compostagem e $11 \%$ são tratados por meio de incineração moderna, como ilustrado na figura 10. Embora, globalmente, 33\% dos resíduos sólidos ainda sejam despejados abertamente em lixões (figura 10), fica evidente cada vez mais que a adoção de padrões de produção e consumo sustentáveis e o gerenciamento adequado 
dos RSU podem reduzir significativamente os impactos ao ambiente e à saúde pública (WB, 2018).

Figura 10- Percentual: Nível Global- Disposição e Tratamento dos Resíduos Sólidos.
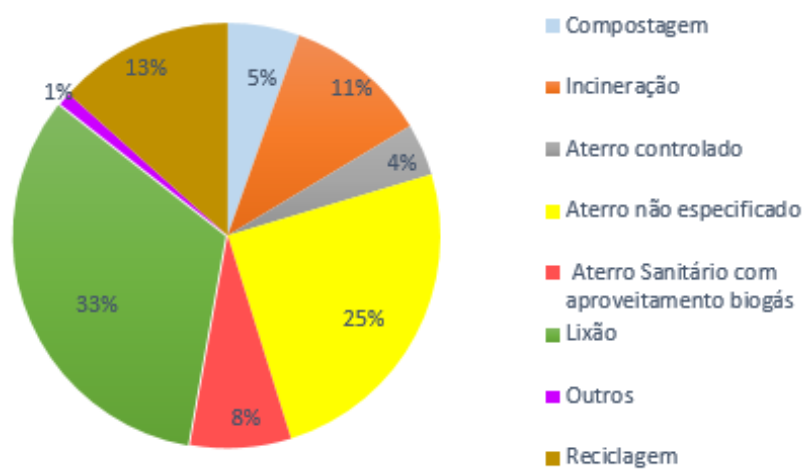

Adaptado de: WB, 2018. Elaborado pela autora.

O despejo de resíduos sólidos a céu aberto (lixão), varia significativamente entre diferentes regiões do mundo, pelo fato de estar relacionado com o nível de renda populacional e padrão de vida das cidades.

Nos países mais ricos que geram maiores quantidades de resíduos, existe mais capacidade de equacionamento da gestão, por um somatório de fatores que incluem recursos econômicos, preocupação ambiental da população e desenvolvimento tecnológico.

Em cidades de países em desenvolvimento, em função da urbanização muito acelerada, verificam-se déficits na capacidade financeira e administrativa dessas em prover infraestrutura e serviços essenciais como água, saneamento, coleta e destinação adequada do lixo e moradia, e em assegurar segurança e controle da qualidade ambiental para a população (JACOBI; BESEN, 2011).

A figura 11 mostra que a disposição a céu aberto e os aterros não controlados continuam a ser o principal método de disposição de RSU em países em desenvolvimento, em função de não possuir planejamento, recursos e gerenciamento adequado como notado no Sul da Ásia, da África e do Oriente Médio. 
Figura 11- Percentual- Métodos de Disposição Final e Destinação por Região.

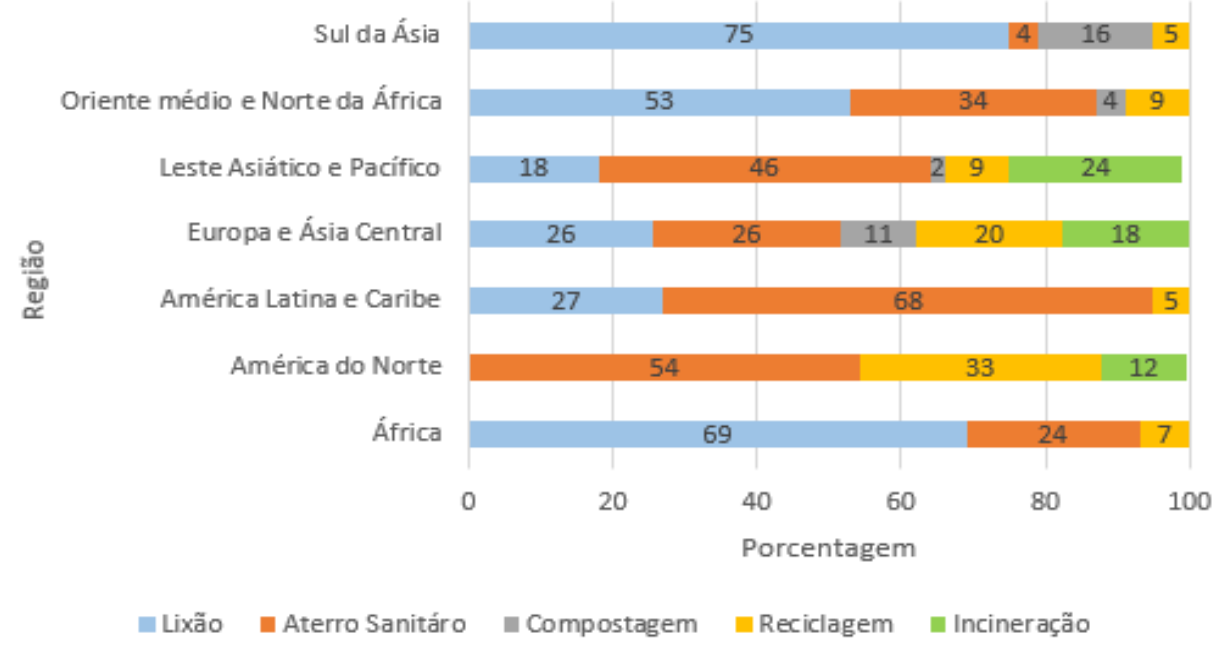

Adaptado de: WB, 2018. Elaborado pela autora.

Além disso, é importante destacar que o Sudeste Asiático é mundialmente conhecido como o receptor de resíduos tóxicos ou não, de países desenvolvidos de maneira irregular. Sabe-se que essa movimentação de resíduos pelos portos dos países asiáticos, na maioria das vezes é realizado de maneira ilegal e até mesmo com documentos falsificados. Em contrapartida, acaba se tornando uma fonte de renda, troca de empregos e lucros para muitos asiáticos, aumentando cada vez mais problemas relacionados a poluição das águas, óbitos e doenças respiratórias (BBC, 2019).

Estima-se que, entre os anos de 2013 e 2014, foram enviados de maneira ilegal para as Filipinas cerca de 69 contêineres com mais e 1.500 toneladas de resíduos tóxicos e recicláveis. E no ano de 2016 a China tenha processado pelo menos metade das exportações mundiais de resíduos de plástico, papel e metais originados do Reino Unido equivalente à 10.000 piscinas olímpicas. Além disso, destaca-se que somente de janeiro a julho de 2018 cerca de 754.000 toneladas de resíduos plásticos foram levadas para a Malásia para serem processados (BBC, 2019).

$\mathrm{Na}$ União Europeia, das técnicas utilizadas para a disposição final dos RSU, o aterramento de resíduos é considerado a menos preferível e sustentável dentro da hierarquia na gestão de resíduos. Mas, quando utilizado para a disposição os resíduos devem ser enviados para aterros que cumpram os requisitos da Diretiva do Parlamento Europeu e do Conselho 1999/31/CE (CE, 2016). 
Perante ao cenário do desperdício de matéria prima secundária, seu potencial de valorização e a diferença de RSU depositados em aterros sanitários pelos estados-membros, a UE atualizou em 2018 a Diretiva dos Aterros Sanitários, no qual determinou uma nova meta, da quantidade total de RSU que devem ser depositados em aterro, não excedendo $25 \%$ em 2035 (EUROTAST, 2020) $^{3}$.

Exemplificando a disparidade entre os estados-membros europeus, no ano de 2011, enquanto seis estados- membros depositavam menos de 3\% dos seus RSU em aterros, 18 depositavam mais de 50\%, ultrapassando alguns casos os $90 \%$. Nesse mesmo ano, a contaminação local do solo, foi estimada em 2,5 milhões de sítios potencialmente contaminados na UE, dos quais cerca de $45 \%$ foram identificados até o momento. Cerca de um terço de um total estimado de 342.000 locais contaminados na UE já foram identificados e cerca de 15\% desses 342.000 locais foram recuperados (EEA, 2014).

Já em 2013, a UE gerou cerca de 2,5 milhões de toneladas de resíduos, 1,6 milhões dos quais não foram reutilizados nem reciclados, com a perda daí resultante para a economia europeia (CE, 2015). Em 2014 com base em 22 países europeus, foi constatado que a principal fonte de contaminação de solo decorre principalmente da disposição de resíduos, conforme demonstrado na figura 12.

Figura 12- Principais fontes de contaminação do solo na Europa.
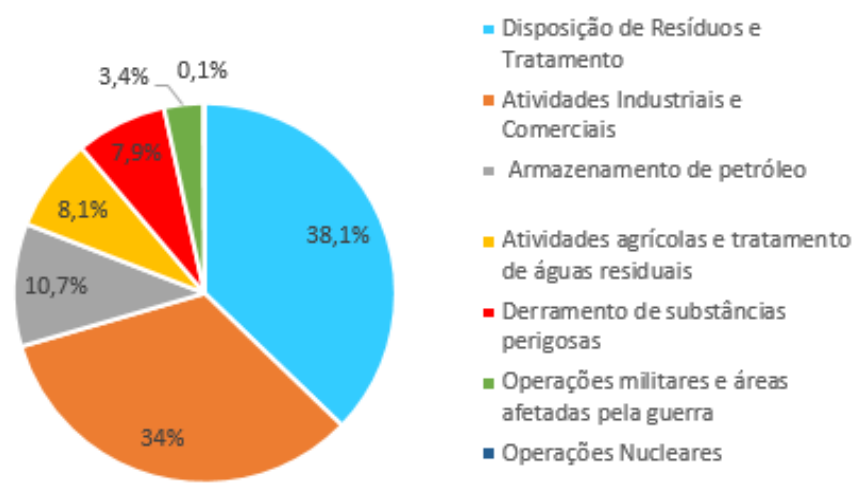

Adaptado de: EEA, 2014. Elaborado pela autora.

No entanto, apesar do aumento dos resíduos gerados na UE houve redução da quantidade total de RSU depositados em aterros nos últimos tempos, em função do

\footnotetext{
${ }^{3}$ Disponível online: <https://ec.europa.eu/eurostat/web/waste/targets>. Acesso em: 20 ago. 2020.
} 
investimento e crescimento na modernização e novas tecnologias de separação, reciclagem e de instalações centralizadas para o tratamento de RSU (WB, 2018).

A figura 13 mostra a taxa de reciclagem e recuperação de resíduos de embalagens alcançada pelos países europeus (UE-27), desde ano de 2007. Essa taxa de valorização, passou apresentar um crescimento a partir do ano de 2008, em função de uma das metas estabelecidas na Diretiva de Embalagens e Resíduos de Embalagens (94/62 /CE), voltada à prevenção ao setor produtivo.

$\mathrm{O}$ artigo $6^{\circ}$ da Diretiva de Resíduos de Embalagens estabelece os seguintes objetivos: uma taxa de recuperação mínima de $60 \%$ (incluindo a incineração de resíduos); entre 55\% e 80\% dos resíduos de embalagens a serem reciclados; com taxas mínimas de $60 \%$ para vidro, papel e papelão; $50 \%$ para metais; 22,5\% para plásticos; e 15\% para madeira (CE, 1994).

Figura 13- Taxas de reciclagem e recuperação de resíduos de embalagens na Europa.

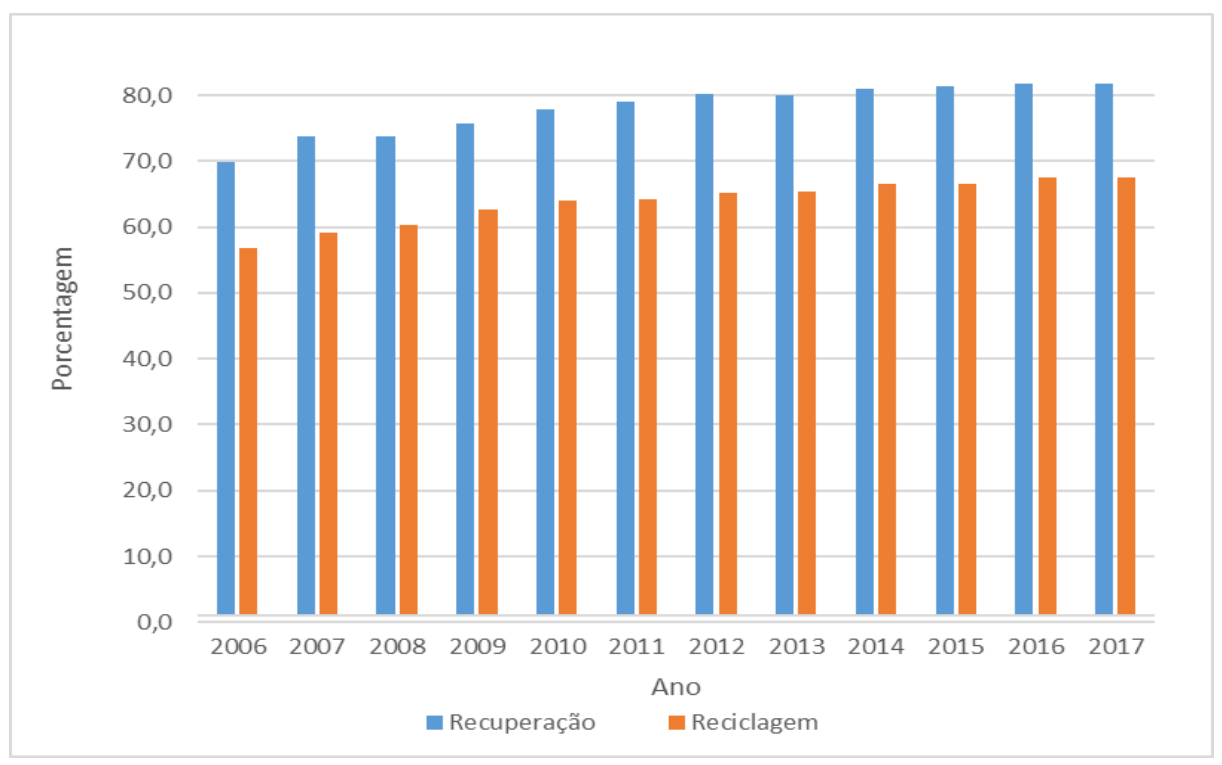

Adaptado de: EUROTAST, 2020. ${ }^{4}$ Elaborado pela autora.

Na figura 14 são apresentados a proporção de tratamento para todos os resíduos de embalagens em 2017. A principal forma de recuperação em todos os países foi a reciclagem, entretanto, os países que utilizaram a incineração com recuperação de energia como método padrão de eliminação de resíduos alcançaram uma taxa de recuperação significativamente maior.

\footnotetext{
${ }^{4}$ Disponível online: <https://ec.europa.eu/eurostat/statistics-explained=Packaging_waste_statistics>. Acesso em: 20 ago. 2020.
} 
Este foi o caso da Finlândia (45,7\%), Áustria (21,5\%), Luxemburgo (19,5\%), Holanda $(12,6 \%)$, Irlanda (11,7\%), Bélgica (11,1\%), Portugal (10,2\%) e Itália $(10,2 \%)$, bem como a Noruega $(34,7 \%)$ e Liechtenstein $(25,7 \%)$.

Figura 14- Percentual de tratamento dos resíduos de embalagens por país.

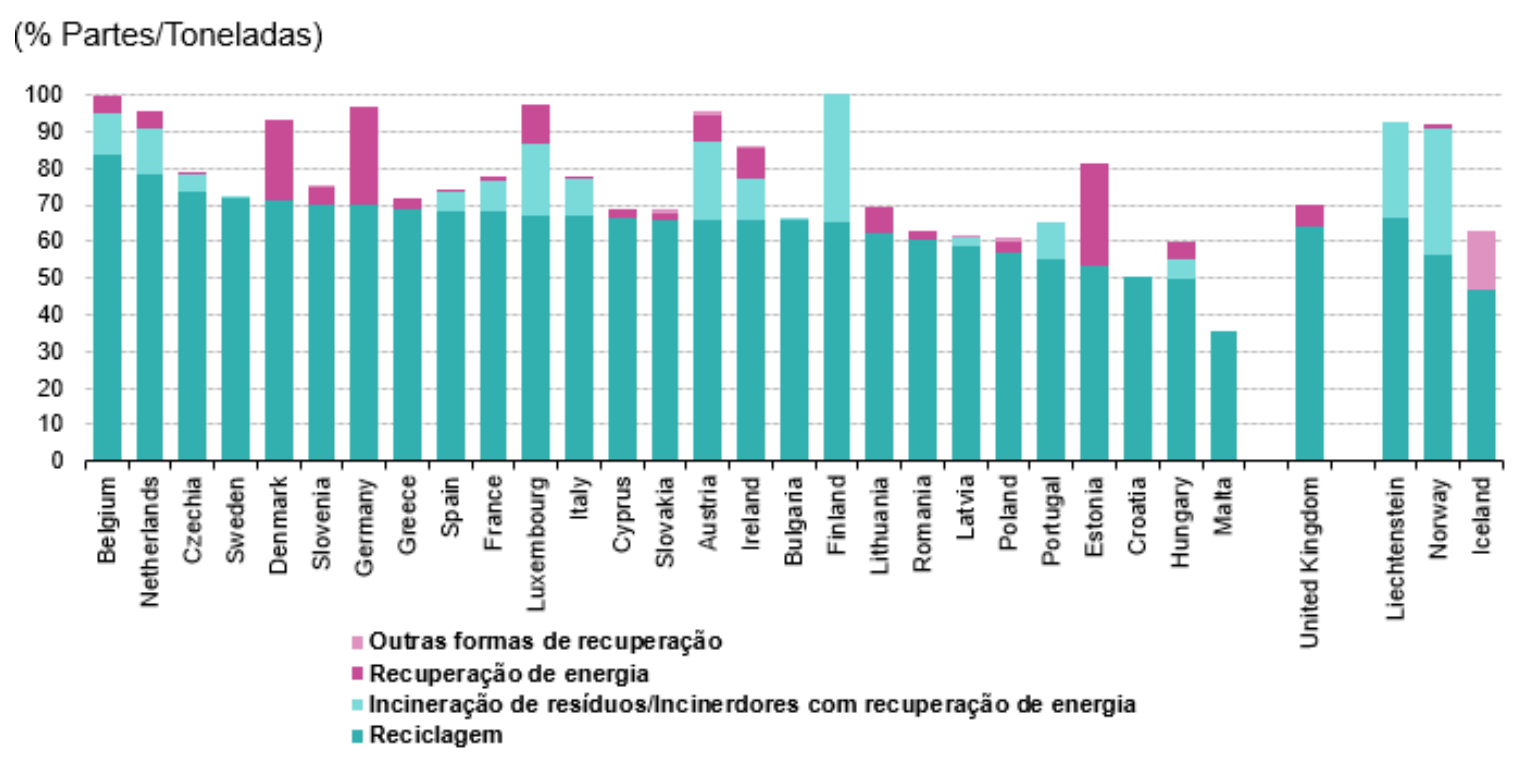

Adaptado de: EUROTAST, 2020.5

Diante da implementação das tecnologias de separação, reciclagem e tratamento de RSU, a utilização dos aterros sanitários diminui a cada ano. Segundo acompanhamento realizado pela EUROSTAT (2020), países como Alemanha, Bélgica, Suíça, Dinamarca e Holanda destinam apenas $1 \%$ de seus RSU para aterros sanitários.

Nos Estados Unidos, a Agência de Proteção Ambiental (Environmental Protection Agency- EPA) é a responsável pelo estabelecimento de padrões nacionais de gestão de resíduos sólidos, bem como pelo monitoramento e fiscalização nos estados. Também considera os aterros sanitários a estratégia menos favorável ambientalmente dentro da hierarquia da gestão dos RSU, similar à Europa.

Segundo WB (2018), dos países da América do Norte e comparado a outros países desenvolvidos, os Estados Unidos ainda destina mais da metade dos RSU gerados para os aterros sanitários. Na figura 15 são apresentados dados do período de 1960 a 2017 sobre a destinação dos RSU no país.

\footnotetext{
5 Idem ao 4.
} 


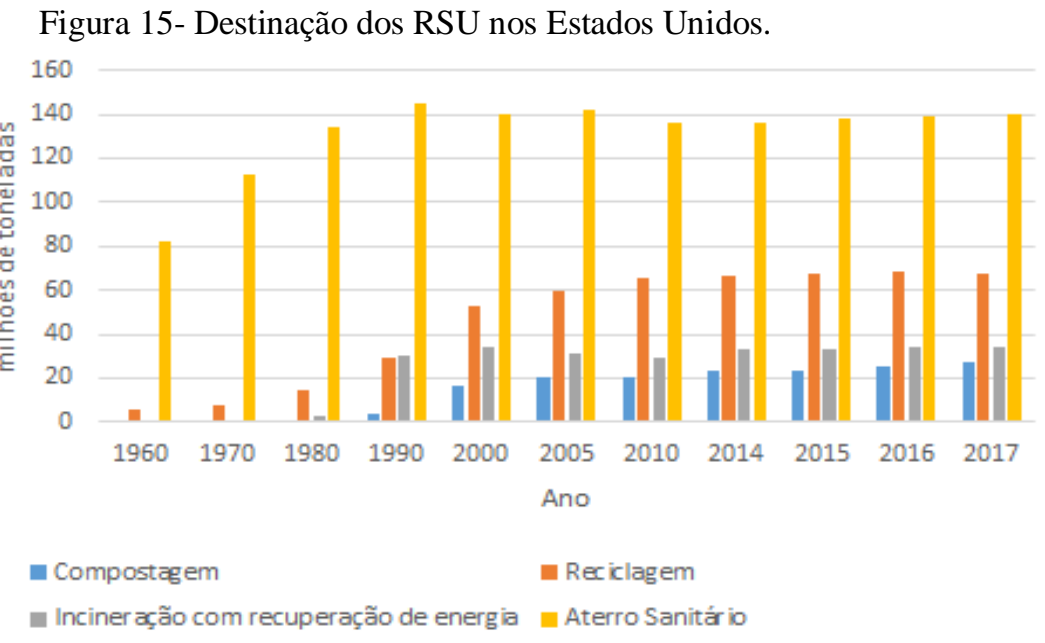

Adaptado de: USEPA, $2019^{6}$. Elaborado pela autora.

De acordo com a figura 15, nota-se que quantidade total de RSU gerado nos EUA cresceu continuamente de 88 milhões de toneladas em 1960, para um pico de 268 milhões de toneladas em 2017. Dos RSU gerados em 1960, 6\% foram reciclados e 94\% depositados em aterro ou descartados usando outros métodos, incluindo queima a céu aberto. Em 2017, 25\% do RSU foi reciclado, $10 \%$ compostado, $13 \%$ foi incinerado com recuperação de energia e $52 \%$ foi para o aterro sanitário.

De modo geral, percebe-se que mesmo com a gestão integrada de resíduos implantada no país, a disposição em aterro sanitário é a técnica mais utilizada. Ao que tange a valorização dos resíduos, nota-se que nas últimas décadas, houve um crescimento constante na reciclagem e compostagem, enquanto as quantidades totais depositadas em aterro atingiram o pico em 1990 (145 milhões de toneladas) e geralmente diminuíram desde então (140 milhões de toneladas em 2017). Em contraponto, as quantidades totais incineradas com recuperação de energia permaneceram razoavelmente estáveis desde 1990, com cerca de 29 milhões de toneladas ${ }^{7}$.

Já no Japão, em função da diversidade das alternativas tecnológicas e escassez de áreas livres para a implantação de aterros sanitários, o uso intensivo no processo de incineração para a redução do volume de resíduos sólidos é bastante frequente. Neste caso, os aterros sanitários são utilizados em apenas $2 \%$, geralmente para a disposição de resíduos não

\footnotetext{
${ }^{6}$ Disponível online: <https://cfpub.epa.gov/roe/indicator.cfm?i=53\#1〉. Acesso em: 20 ago. 2020.

${ }^{7}$ Idem ao 6.
} 
inflamáveis e resíduos após tratamento, como é caso das cinzas dos incineradores (BNDES, 2013).

Ainda de acordo com os dados da EUROTAST (2020), entre os membros do G20 (figura 16), a Turquia (90,2\%) relatou que uso mais frequente de aterros sanitários em 2017 e o Japão relatou o uso mais frequente de incineração (78,5\%; dados de 2016) para tratar resíduos urbanos. Na Coreia do Sul, quase três quintos $(59,2 \%)$ de todos os resíduos urbanos foram reciclados em 2016, com a próxima maior participação na Austrália (42,0\%; dados de 2015), seguido pela UE-27 (30,8\%), o Reino Unido (27,6\%) e os Estados Unidos (25,8\%; dados de 2015). No Reino Unido (17,3\%) e na UE-27 (17,0\%), dos resíduos urbanos foram compostados em 2017, aproximadamente o dobro da segunda maior parcela entre os membros do G20, 8,9\% nos Estados Unidos em 2015.

Figura 16- Tratamento dos RSU no Mundo.

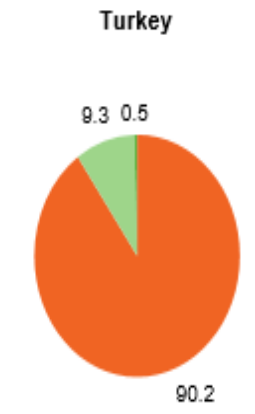

EU-27

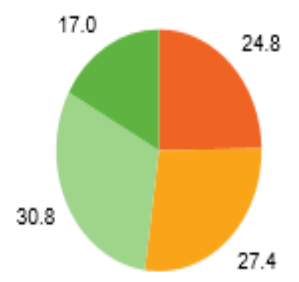

Canada

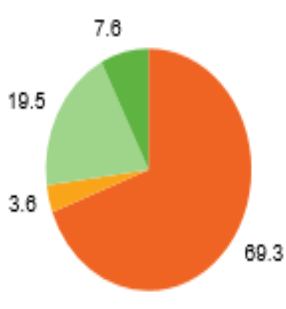

United Kingdom

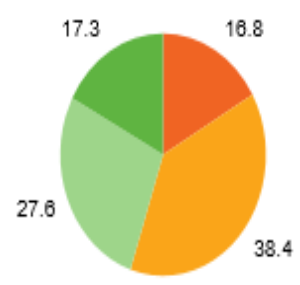

United States

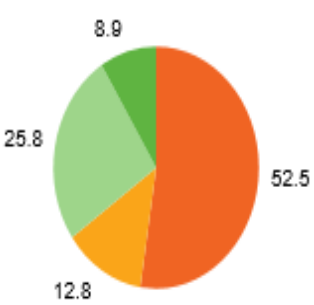

South Korea

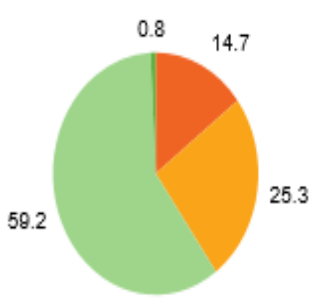

Australia

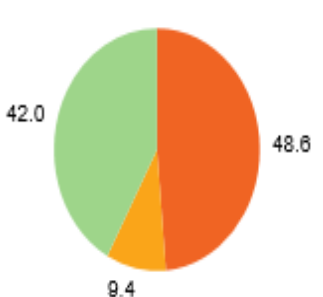

Japan

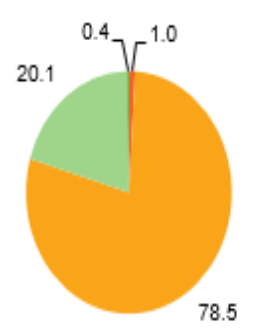

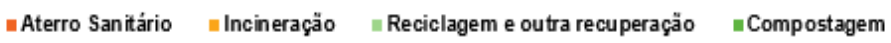

Adaptado de: EUROTAST, 2020. ${ }^{8}$

\footnotetext{
${ }^{8}$ Disponível online: < https://ec.europa.eu/eurostat/statistics-explained/index.php?title=The_EU_in_the_world__environment\#Waste>. Acesso em 25 ago. 2020.
} 
Desta forma, nota-se que o cenário mundial relacionado à disposição final de RSU em aterro sanitário, encontra-se em constante evolução e aprimoramento, sendo a maioria coletados e destinados para técnicas de valorização, entre eles a compostagem, a reciclagem e a incineração com aproveitamento energético. Este modelo de gestão conserva os recursos naturais, reduz o desperdício, retarda a mudança climática e minimiza os impactos ambientais, sociais e econômicos.

Mas, também pode-se identificar que ainda em alguns países desenvolvidos, mesmo com unidades adequadas e licenciadas ambientalmente e a implantação da hierarquia de gestão de resíduos, a disposição em aterro sanitário é a mais frequente, em função de aspectos como: menor custo operacional, indisponibilidade de área livre, tipo de relevo e condição pluviométrica da região.

\subsubsection{Panorama Brasileiro: Município de São Paulo}

São Paulo é a sexta cidade mais populosa do mundo e possui aproximadamente $6 \%$ da população do Brasil. Tem uma população de 11.253.503 habitantes, segundo o censo de 2010 do Instituto Brasileiro de Geografia e Estatística (IBGE) (IBGE, 2017).

O município de São Paulo é o maior gerador de resíduos sólidos produzindo diariamente cerca de 20,1 mil toneladas (entre resíduos domiciliares, resíduos de serviços de saúde, resíduos de feiras livres, podas de árvores, entulho) (AMLURB, 2019). Só de RSU são coletadas cerca de 12 mil toneladas/dia (ROSA et al. 2017; AMLURB, 2019).

Todos esses resíduos são de responsabilidade da Prefeitura Municipal de São Paulo, desde a coleta até a sua disposição final que deve ser ambientalmente segura (JACOBI e BESEN, 2011; PGIRS, 2014).

A geração média per capita de resíduos domiciliares é de aproximadamente 1,2 $\mathrm{kg} /$ habitante por dia, apresentando uma variação entre as subprefeituras, como por exemplo, 0,63 kg/habitante em Cidade Tiradentes, um dos distritos mais pobres da cidade e 1,73 kg/habitante em Pinheiros, um dos bairros com melhor status socioeconômico no ano de 2012 (PGIRS, 2014).

De acordo com as análises gravimétricas realizadas dos RSU gerados no município, há predominância de resíduos úmidos e secos, sendo: $51 \%$ de fração orgânica de resíduos compostáveis, 35\% de resíduos secos recicláveis (papel, vidro, plástico, metal) e 14\% de rejeitos (MMA, 2013; PGIRS, 2014). 
No município de São Paulo, diariamente 6.300 toneladas de resíduos orgânicos gerados são totalmente dispostas em aterros sanitários, esgotando sua vida útil e consumindo com voracidade o espaço disponível para os rejeitos. Além disso, destaca-se que essa disposição contribui para o aumento da geração de gases de efeito estufa, despertando para a necessidade de melhorias para a valorização desses resíduos (PGIRS, 2014).

Cabe lembrar que apenas os rejeitos deveriam ser encaminhados aos aterros sanitários, depois de esgotadas todas as possibilidades de tratamento e recuperação por processos tecnológicos disponíveis e economicamente viáveis, por não apresentarem outra possibilidade de valorização, a que não seja a disposição final ambientalmente adequada (BRASIL, 2010).

Deste modo, os resíduos orgânicos não estão sendo destinados para os locais corretos, apresentando-se em desacordo com o que está estabelecido no Plano de Gestão Integrada de Resíduos Sólidos da Cidade de São Paulo ${ }^{9}$ (PGIRS, 2014), sendo necessário um conjunto de ações voltadas para redução e valoração desses resíduos.

MORAES e BORJA (2015) destacam a importância de uma mudança no modelo atual de gestão de RSU predominante no Brasil, pois ainda se mostra inadequado necessitando de melhorias no gerenciamento.

O modelo atual não segue as recomendações estabelecidas pela PNRS, visando a ordem de prioridade de gestão: não geração, nos 3R's- (reduzir, reutilizar e reciclar), coleta tradicional, tratamento e disposição final.

Outro ponto que também é enfatizado e que precisa de melhoria é a responsabilidade compartilhada pelo ciclo de vida do produto entre os fabricantes, comerciantes, importadores, distribuidores, cidadãos, setor privado e os órgãos governamentais, destacando a importância da participação de cada ator envolvido para atender o manejo e controle adequado dos resíduos gerados.

Entretanto, mesmo após instituída a PNRS no Brasil, no município de São Paulo é preocupante a situação de coleta e destinação dos resíduos. Em muitos locais ainda é possível identificar resíduos lançados em rios, córregos, vias públicas e terrenos vazios, resultando em graves consequências para a paisagem urbana, meio ambiente e para a saúde da população (JACOBI e BESEN, 2011), ilustrado na figura 17.

\footnotetext{
${ }^{9}$ Plano de Gestão Integrada de Resíduos Sólidos (PGIRS) - Descreve as ações referentes ao manejo dos resíduos sólidos, estabelecendo os atores envolvidos de como se deve atuar para atingir os objetivos. Disponível online: https://www.prefeitura.sp.gov.br/cidade/secretarias/upload/servicos/arquivos/PGIRS2014.
} 
Figura 17- Descarte de resíduos em via pública- Município de São Paulo.

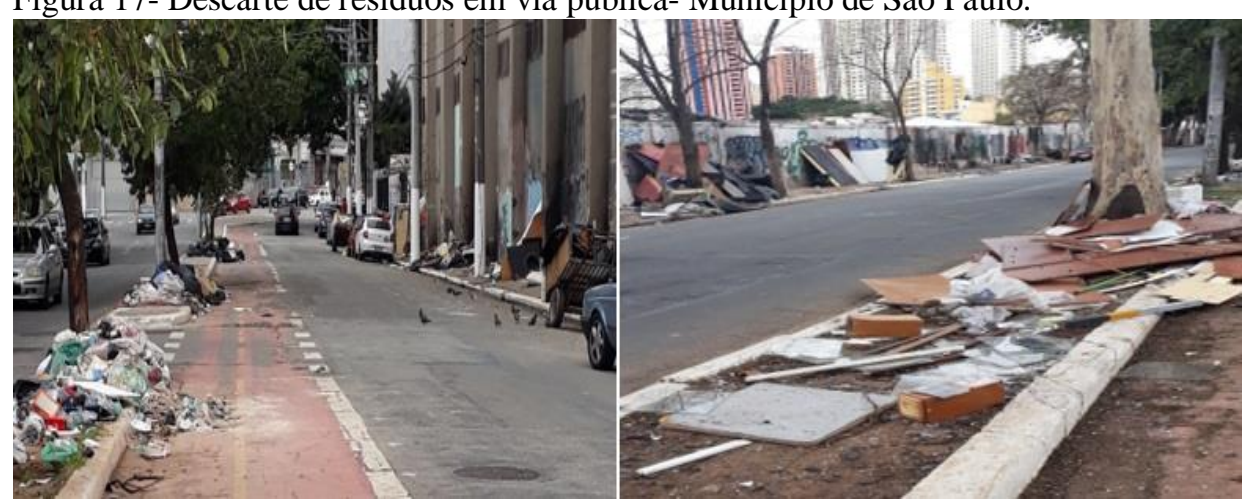

Extraído de: Arquivo da autora, set. 2019.

Ainda de acordo com as exigências previstas na lei, a extinção dos lixões no país era até 2014 com a proibição da catação, criação de animais e instalação de moradia nos aterros, metas até então não cumpridas.

Segundo (WASTE, 2014) entre os cinquenta maiores lixões ainda em operação no mundo, no Brasil é possível destacar o Lixão Estrutural em Brasília. Esse lixão é um dos grandes problemas para o governo no Distrito Federal por ser o maior local de disposição de resíduos em funcionamento por mais de 50 anos.

Sua área corresponde a 136 hectares equivalente a 380 campos de futebol, e recebe cerca de 21 a 30 milhões de toneladas de resíduos, atingindo uma altura de 60 metros. Nesse local, já ocorreram acidentes com os catadores e outra grande preocupação é a possível contaminação da água subterrânea, uma vez o Parque Nacional de Brasília está localizado a $0,5 \mathrm{~km}$ do lixão e seus mananciais que abastecem o estado com $27 \%$ da sua água potável (WASTE, 2014).

Reconhece-se que há muito o que se fazer quanto ao gerenciamento de resíduos sólidos urbanos e que locais inadequados abertos ocasionam grandes impactos negativos na economia, na sociedade, bem como na saúde pública, meio ambiente, qualidade e segurança das pessoas que vivem ao seu redor.

Para consolidar a preservação dos recursos naturais através do desenvolvimento sustentável e da promoção de um ambiente seguro com menos risco à população, é importante enfatizar que o poder público fica obrigado a assumir uma nova consciência sobre o papel ambiental, econômico, social e político, exigindo a integração de toda a sociedade no processo de construção do futuro (MMA, 2016). 
A Constituição da República Federativa do Brasil de 1988 no capítulo VI do Meio Ambiente pontuou-se, que:

Art.225- Todos têm direito ao meio ambiente ecologicamente equilibrado, bem de uso comum do povo e essencial à sadia qualidade de vida, impondo-se ao Poder Público e à coletividade o dever de defendê-lo e preservá-lo para as presentes e futuras gerações (BRASIL, 1988).

\subsubsection{Métodos de Disposição de Resíduos Sólidos no Solo}

No Brasil, constitucionalmente, é de competência do poder público local o gerenciamento dos resíduos sólidos produzidos em suas cidades.

Segundo a Pesquisa Nacional de Saneamento Básico - PNSB 2008, 61,2\% das prestadoras dos serviços de manejo dos resíduos sólidos urbanos eram entidades vinculadas à administração direta do poder público; $34,5 \%$, empresas privadas sob o regime de concessão pública ou terceirização; e 4,3\%, entidades organizadas sob a forma de autarquias, empresas públicas, sociedades de economia mista e consórcios.

Os serviços de manejo dos resíduos sólidos compreendem a coleta, a limpeza pública bem como sua disposição final, a qual exerce um forte impacto no orçamento das administrações municipais (PNSB, 2010).

A prática de dispor resíduos sólidos no solo ambientalmente adequada é a técnica mais antiga e conhecida no mundo todo, embora vêm se alterando nos últimos 20 anos. No entanto, apesar da legislação, ainda é possível identificar que nem todos resíduos gerados são coletados pelos municípios, e muitos são destinados para os lixões ou aterros controlados.

Lixões são locais nos quais os resíduos de diversos tipos são despejados diretamente no solo e que não possuem quaisquer critérios técnicos e medidas de controle e redução de impactos ambientais (PNSB, 2010).

Já aterros controlados diferenciam-se dos lixões apenas por contarem com uma cobertura de camada de terra, após o descarregamento dos resíduos, o que evita em parte a proliferação de vetores, mas não elimina a contaminação do solo e do lençol freático por chorume (PNSB, 2010; GOUVEIA; PRADO, 2010).

Segundo a Associação Brasileira de Empresas de Limpeza Pública e Resíduos Especiais- ABRELPE (2018/2019), ainda existem lixões e locais inadequados em todas as regiões do país, os quais receberam 29,5 milhões de toneladas de resíduos sólidos urbanos, 
evidenciando um elevado potencial de poluição ambiental e impactos negativos sobre a saúde das pessoas vivem no entorno.

É importante lembrar essas práticas de disposição são reconhecidas como inadequadas, como preconiza a Política Nacional de Resíduos Sólidos- PNRS, por não serem seguras do ponto de vista ambiental e da saúde humana, exigindo de certa forma soluções urgentes voltadas para as mudanças social, econômica e cultural da sociedade.

Segundo a PNRS, disposição ambientalmente segura baseia-se na distribuição ordenada de rejeitos em aterros sanitários, observando normas operacionais específicas de modo a evitar danos ou riscos à saúde pública e à segurança e a minimizar os impactos ambientais (BRASIL, 2010)

Sendo assim, define-se aterro sanitário como uma obra de engenharia que tem vida útil determinada para a disposição dos resíduos sólidos no solo, sob controle técnico e operacional permanente, de modo a que nem os resíduos, nem seus efluentes líquidos e gasosos, venham a causar danos à saúde pública e/ou ao meio ambiente.

Para tanto, o aterro sanitário deverá ser localizado, projetado, instalado, operado e monitorado em conformidade com a legislação ambiental vigente e com as normas técnicas oficiais (PNSB, 2010).

SAMADDER et al. (2017) relatam que o princípio de funcionamento dos aterros sanitários é como os reatores biológicos, onde os resíduos sofrem transformações físicas, químicas e biológicas. No entanto, os aterros sanitários malconservados durante sua operação e/ou após o fechamento são propensos à contaminação da água subterrânea por percolação de chorume, sendo este o problema mais agudo nas nações subdesenvolvidas e em desenvolvimento.

O quadro 6 apresenta resumidamente as principais características de cada método de disposição de resíduo sólido, sendo possível identificar as diferenças entre si.

Quadro 6- Características dos Métodos de Disposição de Resíduos Sólidos no solo.

\begin{tabular}{|c|c|c|c|}
\hline Descrição & Lixão & Aterro Controlado & Aterro Sanitário \\
\hline Seleção da Área & NE & NE & E \\
\hline $\begin{array}{c}\text { Coleta e Tratamento } \\
\text { Lixiviado }\end{array}$ & NE & NE & E \\
\hline Tratamento do Biogás & NE & NE & E \\
\hline Cobertura de Terra & NE & E & E \\
\hline $\begin{array}{c}\text { Delimitação da Área/ } \\
\text { Cercamento }\end{array}$ & NE & E & E \\
\hline Compactação dos resíduos & NE & E \\
\hline
\end{tabular}

continua... 


\begin{tabular}{|c|l|l|l|}
\hline Impermeabilização do solo & NE & NE & E \\
\hline Balança dos resíduos & NE & NE & E \\
\hline
\end{tabular}

Legenda: NE: não existe. E: existe. Adaptado de: PNSB, 2010. Elaborado pela autora.

\subsubsection{Aterros Sanitários}

Atualmente os projetos de aterros sanitários seguem legislação e normas específicas que devem incorporar recursos e técnicas para evitar a contaminação do solo e água subterrânea e minimizar os impactos ambientais. Entre as técnicas encontram-se a impermeabilização do solo por meio de compactação de camadas de argilas, o uso de geomembranas, sistemas de drenagem das águas fluviais, lixiviados e gases, ilustrado na figura 18 (CANDIANI; VIANA, 2017).

Figura 18- Esquema de Aterro Sanitário de Resíduos Sólidos Urbanos.

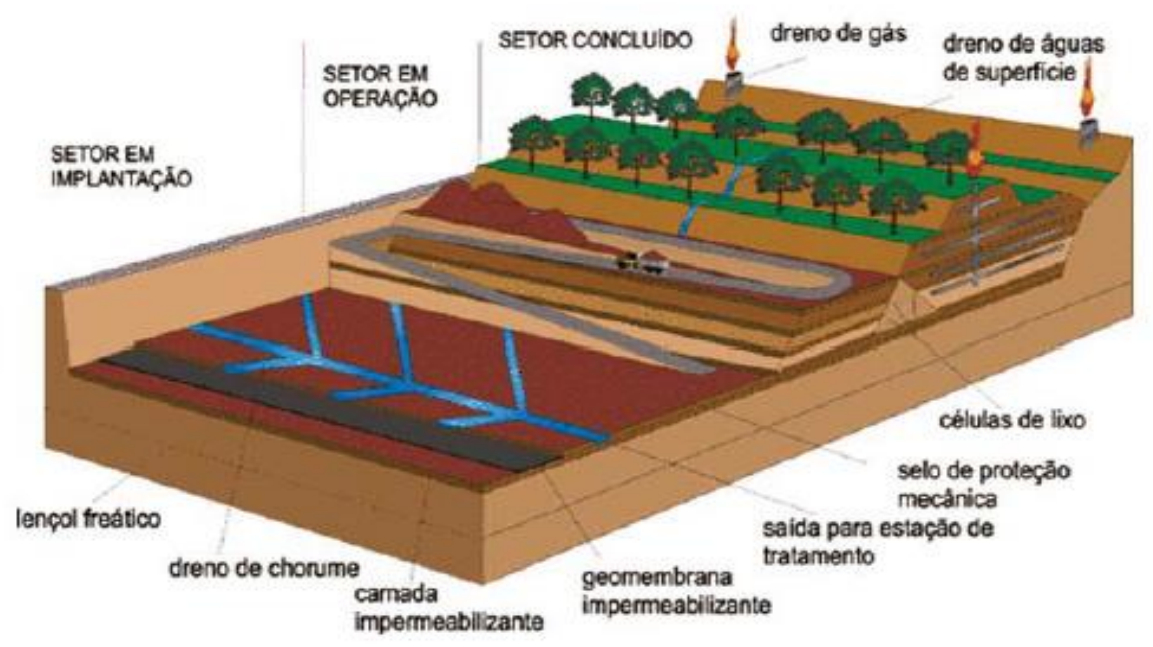

Extraído de: BNDES, 2013.

Para enfrentar as questões de gestão e gerenciamento relacionadas aos RSU a Prefeitura de São Paulo atualmente utiliza três aterros: Aterro Sanitário Caieiras; Centro de Disposição de Resíduos Pedreira e o Central de Tratamento de Resíduos Leste. Dois, pertencem ao setor privado e um é operado por concessão pública (AMLURB, 2009). Há duas áreas que encerraram suas atividades recentemente: o Aterro Bandeirantes em 2007 e o Aterro São João em 2009.

Buscando alcançar a prevenção e o controle da poluição, a proteção e a recuperação da qualidade ambiental e a promoção da saúde pública, os governos federal, estadual e municipal têm adotado as práticas estabelecidas nas seguintes políticas públicas: 
- Política Nacional de Resíduos Sólidos (PNRS) - Lei Federal n.12.305/2010;

- Política Nacional de Saneamento Básico (PNSB) - Lei Federal n.11.455/2007;

- Política Estadual de Resíduos Sólidos do Estado de São Paulo- Lei 12.300/2006.

Para aterros sanitários, as normas e diretrizes seguidas para disposição de RSU no solo são as estabelecidas pela norma ABNT/NBR 13.896/1997. Essa norma apresenta todas as condições mínimas exigíveis para projeto, implantação e operação de aterros de resíduos não perigosos, de forma a proteger adequadamente as coleções hídricas superficiais e subterrâneas próximas, bem como os operadores destas instalações e populações vizinhas. Outras normas complementares estão apresentadas no quadro 7 (ABNT,1997).

Destaca-se que as normas e leis citadas no quadro 7 são relacionadas aos RSU nãoperigosos, assim como aterros sanitários de classe II. Para os resíduos perigosos (classe I) e aterros sanitários de classe I, deve ser levado em consideração outras diretrizes e normas.

Quadro 7- Legislações de Resíduos Sólidos Urbanos e Aterro Sanitários- Classe II.

\begin{tabular}{|c|}
\hline Leis e Normas- Resíduos Sólidos Urbanos e Aterros Sanitários em São Paulo. \\
\hline Política Nacional Resíduos Sólidos (PNRS) - Lei Federal 12.305/2010. \\
\hline $\begin{array}{l}\text { Lei Estadual N. } 12.300 \text { de } 16 \text { de março de 2006- Institui a Política Estadual de RS e define } \\
\text { princípios e diretrizes. }\end{array}$ \\
\hline Política Nacional de Saneamento Básico (PNSB) - Lei Federal n.11.455/2007. \\
\hline NBR 10.004/2004- Resíduos Sólidos- Classificação \\
\hline NBR 10.005/2004- Procedimento para obtenção de extrato lixiviado de RS. \\
\hline NBR 10.006/2004- Procedimento para obtenção de extrato solubilizado de RS. \\
\hline NBR 10.007/2004- Amostragem de Resíduos Sólidos-Procedimento \\
\hline $\begin{array}{l}\text { NBR 12.988/1993- Líquidos Livres- Verificação em amostra em Resíduos- Métodos de } \\
\text { ensaio. }\end{array}$ \\
\hline $\begin{array}{l}\text { NBR 8.419/1992- Apresentação de projetos de aterros sanitários de resíduos sólidos } \\
\text { urbanos- procedimento. }\end{array}$ \\
\hline $\begin{array}{l}\text { NBR 13.896/1997- Aterros de resíduos não perigosos- Critérios para Projeto, Implantação e } \\
\text { Operação- Procedimento. }\end{array}$ \\
\hline $\begin{array}{l}\text { NBR 15.495-1/2007. Poços de monitoramento de águas subterrâneas em aquíferos } \\
\text { granulares- Parte 1: Projeto e construção. }\end{array}$ \\
\hline $\begin{array}{l}\text { Resolução CONAMA N.1, de } 23 \text { de janeiro de 1986- Disciplina o EIA/RIMA- Exigências, } \\
\text { conteúdo, elaboração, responsabilidades e audiência pública. }\end{array}$ \\
\hline $\begin{array}{l}\text { Resolução SMA N. 54, de } 30 \text { de novembro de 2004- Dispõe sobre procedimentos para o } \\
\text { licenciamento ambiental no âmbito da Secretaria do Meio Ambiente. }\end{array}$ \\
\hline $\begin{array}{l}\text { Resolução SMA N.51, de } 25 \text { de julho de } 1997 \text { - Dispõe sobre a exigência ou dispensa de } \\
\text { Relatório Ambiental Preliminar-RAP para os aterros sanitários e usina de reciclagem e } \\
\text { compostagem de resíduos sólidos domésticos operador por municípios. }\end{array}$ \\
\hline
\end{tabular}

SÁNCHEZ (2001) destaca que os sítios de disposição de resíduos urbanos devem ser vistos a priori como locais potencialmente contaminados, áreas cuja reutilização deve ser 
cercada de cuidados principalmente por causa dos riscos que podem ser ocasionados à saúde humana.

\subsubsection{Aterros Controlados e Lixões Desativados}

Atualmente, existem oito locais de disposição de resíduos sólidos desativados pertencentes ao município de São Paulo. Essas áreas operaram de maneira irregular e sem conhecimento técnico, na década de 1970 e serão transformados em parques públicos, apresentadas no quadro 8 .

Quadro 8- Locais de disposição de resíduos no município de São Paulo.

\begin{tabular}{|c|c|c|c|c|}
\hline $\begin{array}{c}\text { Aterros } \\
\text { Controlados/Lixões }\end{array}$ & Início & Desativação & Situação Atual & Região de SP \\
\hline Carandiru & 1977 & 1977 & Parque da Juventude & Zona Norte \\
\hline Engenheiro Goulart & 1975 & 1979 & Parque Ecológico do Tietê & Zona Norte \\
\hline Raposo Tavares & 1967 & 1979 & Parque Raposo Tavares & Zona Oeste \\
\hline Santo Amaro & 1976 & 1995 & $\begin{array}{c}\text { Monitoramento para } \\
\text { encerramento }\end{array}$ & Zona Sul \\
\hline São Mateus & 1984 & 1985 & Monitoramento & Zona Leste \\
\hline Sapopemba & 1979 & 1984 & Parque Aterro Sapopemba & Zona Leste \\
\hline Vila Albertina & 1977 & 1993 & $\begin{array}{c}\text { Contaminada sob } \\
\text { Investigação }\end{array}$ & Zona Norte \\
\hline Vila Jacuí & 1979 & 1988 & $\begin{array}{c}\text { Contaminada sob } \\
\text { Investigação }\end{array}$ & Zona Leste \\
\hline
\end{tabular}

Adaptado de: ROSA et al. 2017. Elaborado e atualizado pela autora.

Muitas dessas áreas foram contaminadas pelos resíduos e chorume produzidos, podendo apresentar riscos à vegetação que do solo depende, à qualidade da água subterrânea e à saúde das pessoas que possam entrar em contato direto com esses sítios contaminados. A maioria se encontra na zona leste e nas bordas da cidade, que antes do surgimento desses locais eram menos ocupadas. No entanto, hoje embora ainda distante do centro, são áreas ocupadas, algumas com boa estrutura de urbanização, e outras precárias com altos índices de violência e invasões, pouca vegetação e com carência de espaços públicos e de lazer (BARROS, 2011; STUERNER et al. 2011; POLZER, 2013).

No município de São Paulo, durante décadas todo o resíduo gerado foi lançado em lixões, e somente em 1974 foi instalado o primeiro aterro municipal em Lauzane Paulista, localizado na zona norte (MORINAGA, 2007).

Muitas áreas tiveram origem em cavas de mineração desativadas que resultaram da atividade de extração, e com o passar dos anos foram incorporadas pela urbanização em razão 
do crescimento horizontal da cidade, transformando-se em zonas predominantemente residenciais (MORINAGA, 2007; BARROS, 2017).

Salienta-se que muitas vezes os riscos associados aos lixões e aos aterros controlados e até mesmo aterros sanitários, não são percebidos pela população em geral, podendo causar graves consequências e complexidade na gestão. Entre os principais impactos ambientais e riscos à saúde humana estão a contaminação do solo e de águas superficiais e subterrâneas, os riscos de explosividade ${ }^{10}$ e os recalques diferenciais (BARROS, 2017).

Em contrapartida, sabe-se que áreas contaminadas por resíduos podem ser reutilizadas de diversas formas em benefício das comunidades, podendo ser um fator indutor do fomento de um planejamento mais sustentável para as cidades (SOUSA, 2003) e, principalmente, de atração de novos empregos e negócios no entorno e contribuindo com a qualidade ambiental do local (SÁNCHEZ, 2001; GÜNTHER, 2006).

SANCHES (2014) ressalta que autoridades do mundo todo vem percebendo a importância de buscar soluções sustentáveis para recuperar áreas degradadas e contaminadas, uma vez que estão localizadas em regiões ricas em infraestrutura.

\subsection{CASOS DE ÁREAS CONTAMINADAS POR RESÍDUOS SÓLIDOS}

Nos últimos trinta anos, muitos países têm desenvolvido e implementado diretrizes de planejamento mais sustentável para as cidades, visando a ocupação e reutilização de áreas contaminadas por resíduos sólidos (SOUSA, 2003). Um dos motivos é a expansão urbana e, principalmente a atração de novos empregos e negócios no entorno, além da melhoraria da qualidade ambiental do local (SÁNCHEZ, 2001; GÜNTHER, 2006).

Embora a origem das áreas contaminadas esteja relacionada com o grau de industrialização do país e a ausência de um sistema de planejamento urbano e o suporte de leis ambientais, o assunto passou a se destacar na agenda ambiental, em meados da década de 1970, após alguns casos internacionais de grande repercussão.

O primeiro caso que ganhou destaque foi o Love Canal, situado na cidade americana de Niágara Falls, estado de Nova York. A princípio, ficou conhecido através de uma obra da

${ }^{10} \mathrm{O}$ gás metano é explosivo entre o limite de explosividade inferior (LEL) de 5\% em volume e o limite de explosividade superior (UEL) de $15 \%$ em volume. No interior do aterro as concentrações são de $50 \%$, muito acima do UEL e, por isso, sem risco de explosividade (BARROS, 2017. p. 264). 
usina hidrelétrica que alterou o desvio de parte do rio Niágara que fora abandonada e posteriormente aterrada com cerca de 21.000 toneladas de produtos químicos e resíduos perigosos, durante os anos de 1940. Posteriormente, essa região do canal se desenvolveu e tornou-se uma escola primária com casas no entorno pela população (SÁNCHEZ, 2001, USEPA, 2018).

Em 1976, foi publicada uma matéria pelo jornal local Niagara Gazette, com informações do depósito de resíduos e a queixa dos moradores quanto a problemas de saúde, levando ao estado de emergência e a providenciar a evacuação de muitas famílias do local (SÁNCHEZ, 2001; MAXIMIANO et al. 2014). Posteriormente, investigações feitas no sítio contaminado revelaram a presença de 248 diferentes substâncias químicas na mistura solo/resíduos e 89 substâncias na água subterrânea, algumas sendo cancerígenas como é caso dos pesticidas e das dioxinas Alloway e Ayres (apud SÁNCHEZ, 2001, p. 86).

Outro caso que gerou bastante polêmica, foi o ocorrido em Lekkerkerk próximo a Roterdã, na Holanda. SÁNCHEZ (2004) relata que residências foram construídas em cima de um aterro, em que haviam sido depositados resíduos de diferentes tipos, onde posteriormente foram evidenciados problemas de saúde nas pessoas expostas às substâncias químicas.

Outro caso que gerou bastante polêmica, foi o ocorrido em Lekkerkerk próximo a Roterdã, na Holanda. SÁNCHEZ (2004) relata que residências foram construídas em cima de um aterro, em que haviam sido depositados resíduos de diferentes tipos, onde posteriormente foram evidenciados problemas de saúde nas pessoas expostas às substâncias químicas.

A partir da repercussão desses casos, foi que a qualidade do solo deixou de ser considerada apenas como um assunto de livros e trabalhos acadêmicos (SÁNCHEZ, 2001), passando a contribuir para a adoção de legislações específicas para a proteção do solo (SÁNCHEZ, 2004).

No Brasil, o primeiro registro de acidente pelo aterramento de resíduos de grande repercussão ocorreu na Baixada Santista, nos anos de 1980, em São Paulo, provocado pela contaminação de solo por diversos depósitos de resíduos de organoclorados oriundos da fabricação de agrotóxicos pela Rhodia S.A., objeto de uma das primeiras ações civis públicas ambientais (SÁNCHEZ, 2001). Ao menos 156 pessoas tiveram sua saúde afetada por contaminação, além da ocorrência de morte de um funcionário em 1992, o que provocou o fechamento da fábrica em 1993 (BARROS, 2017).

Em seguida, após o ocorrido, a Rhodia procedeu à remoção da maior parte dos resíduos e do solo dos locais contaminados e até 1994 teria gasto cerca de US\$ 60 milhões. 
Em 1995 assinou um termo de ajustamento de conduta (TAC), comprometendo-se promover a descontaminação da área e o tratamento da saúde da população, mas até hoje o caso permanece sem uma decisão final (SÁNCHEZ, 2001; BARROS, 2017).

Outro caso que despertou a atenção dos órgãos públicos foi o da Cidade dos Meninos, no Rio de Janeiro, em Duque de Caxias. Em 1947, o Ministério da Educação e Saúde, com o objetivo de erradicar as endemias rurais, como a doença de chagas, malária e a febre amarela, criou o Instituto de Malariologia, constituído por oito pavilhões (BRASIL, 2004). Em 1950, iniciou-se a produção de hexaclorociclohexano e a manipulação de outros pesticidas como o diclorodifeniltricloroetano (DDT) para o controle dos transmissores das doenças. Mais tarde, essa fábrica foi abandonada por mais de quarenta anos com substâncias estocadas a céu aberto espalhadas em contato direto com o solo sem nenhuma proteção (BRASIL, 2004; CÔRTES et al. 2011). Diante desse fato, foi comprovada a contaminação dos compartimentos ambientais e da população da Cidade dos Meninos, onde notou-se a importância de estudos detalhados voltados para a avaliação de risco à saúde das populações, assim como estudos adicionais de remediação (CÔRTES et al. 2011).

A partir de diversas situações dessa natureza que repercutiram na cidade de São Paulo e no Rio de Janeiro, foi possível identificar diversos problemas à saúde humana e alterações socioambientais no espaço urbano. Entre os casos, destacam-se:

\subsubsection{Barão de Mauá}

De acordo com as informações constantes da internet da página da $\operatorname{CETESB}^{11}$, o Conjunto Residencial Barão de Mauá, localizado no Parque São Vicente, no município de Mauá é uma área contaminada por compostos orgânicos e inorgânicos, alguns deles voláteis, entre eles o benzeno, clorobenzeno, trimetilbelzeno e decano.

Foi construído sobre um terreno pertencente à empresa de amortecedores Cofap, o qual havia sido aterrado com resíduos sólidos industriais e areia de fundição. Como não havia controle da área pelos proprietários, outras substâncias tóxicas de origem desconhecida, foram ali sendo depositadas irregularmente.

\footnotetext{
${ }^{11}$ Disponível online: https://cetesb.sp.gov.br/areas-contaminadas/2013/11/22/condominio-residencial-barao-demaua-municipio-de-maua/. Acesso em: 26 out. 2019.
} 
Nem todos os edifícios foram construídos sobre os resíduos; a maioria foi implantado em terreno que não sofreu contaminação, como demonstra a figura 19. Mas, a ocorrência de uma explosão causada pelo acúmulo de gases produzidos pelo aterro no ano 2000, resultou na morte de um trabalhador, quando realizava manutenção em uma das caixas d'água subterrâneas instaladas no conjunto residencial. Daí então, a CETESB aplicou penalidade de multa à empresa responsável pela construção dos edifícios, e exigiu a adoção de ações de monitoramento, identificação, caracterização e remediação do solo e águas subterrâneas.

Figura 19- Barão de Mauá: local aterrado com os resíduos.

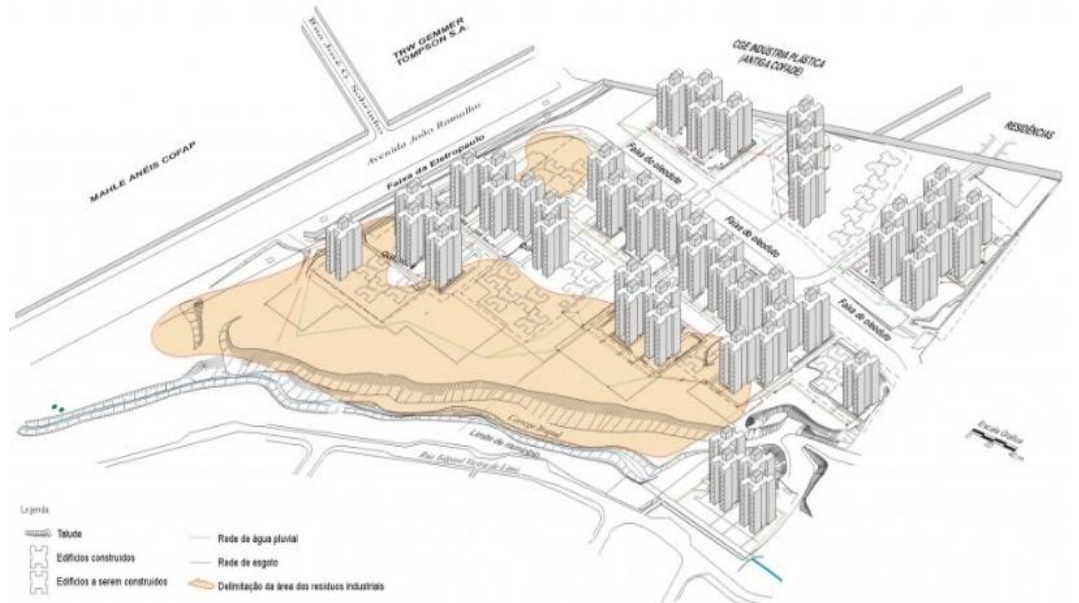

Extraído de: <https://cetesb.sp.gov.br/areas-contaminadascondominio-residencial-barao-de-maua-municipiode-maua>. Acesso em: 26 out. 2019.

\subsubsection{Aterro Industrial Mantovani S/C Ltda}

O Aterro Industrial Mantovani S/C Ltda está localizado no Sítio Pirapitingui, em área rural do município de Santo Antônio de Posse, em São Paulo. Iniciou suas atividades como aterro em 1974 até setembro de 1987. Durante esse período, recebeu resíduos industriais de todos os tipos e resíduos gerados no processo de reciclagem de óleos lubrificantes até que teve suas atividades interrompidas pela ação de fiscalização e controle da CETESB.

Porém, outro empreendimento, a Central Técnica de Tratamento e Disposição de Resíduos Industriais -CETRIN, também exerceu a atividade de aterro industrial na mesma área, recebendo basicamente lodos de sistemas de tratamento de efluentes líquidos de galvanoplastias, no período de 1984 a 1987, quando também teve suas atividades interrompidas, pela CETESB. 
Em seguida, a CETESB exigiu a paralisação de suas atividades em 1987, quando foi verificada a existência de contaminação do solo e das águas subterrâneas por diversas substâncias perigosas no interior da propriedade do aterro, autuando o Aterro Mantovani e exigindo a recuperação ambiental da área ${ }^{12}$.

Após a paralisação das atividades dos empreendimentos, a CETESB mantém uma sistemática fiscalização e monitorização do local, por meio de inspeções técnicas e de amostragens periódicas de poços de monitoramento, poços de abastecimentos de sítios vizinhos e corpos d'água.

\subsubsection{Conjunto Habitacional- Vila Nova Cachoeirinha}

O Conjunto Habitacional Nossa Senhora da Penha, localizado à Av. João dos Santos Abreu s/n, adjacente ao cemitério Vila Nova Cachoeirinha, zona norte de São Paulo, abriga um terreno que fui utilizada como lixão e recebeu diversos tipos de resíduos (orgânicos, industriais, construção civil e hospitalar) por cerca de vinte anos, entre os anos de 1960 e 1980. Uma investigação do subsolo da área do empreendimento, realizada em agosto de 1999, constatou a presença de grossa espessura de aterro composto por $55 \%$ de solo, $33 \%$ de entulho, $33 \%$ de resíduos diversos e $12 \%$ de possível material de dragagem do Rio Tietê ${ }^{13}$.

Sobre o local foram implantadas unidades habitacionais pela COHAB e duas escolas municipais (MORINAGA, 2013). A investigação ambiental confirmou contaminação do solo e das águas subterrâneas por substâncias orgânicas e inorgânicas, representando risco à segurança e saúde pública pela presença de substâncias voláteis e tóxicas com alto índice de explosividade de gás metano.

Também foi recomendado que grande parte da área deveria ser interditada para ocupação residencial e a instalação imediata de poços dentro das escolas ou suspendidas as atividades escolares. Em 2007 ficou estabelecido que os órgãos competentes envolvidos deveriam providenciar a remoção de todos os moradores do conjunto habitacional e transferência dos alunos das escolas até controle da situação atual.

\footnotetext{
12 Disponível online em: https://cetesb.sp.gov.br/areas-contaminadas/2013/11/22/aterros-industriais-mantovanie-cetrin/. Acesso em: 20 ago. 2019.

${ }^{13}$ Disponível online em: https://cetesb.sp.gov.br/areas-contaminadas/2013/11/22/conjunto-cohab-vila-novacachoeirinha-municipio-de-sao-paulo/. Acesso em: 26 out. 2019.
} 
Nos dias atuais, a área permanece sem grandes alterações e sem maiores esclarecimentos sobre a contaminação. As escolas foram desativadas em 2013 e a COHAB estuda a possibilidade de remover os moradores, mediante indenização, e mantém em operação o sistema de drenagem de gases instalado no local, considerado insuficiente pela CETESB.

\subsubsection{Shopping Center Norte}

A área ocupada pelo Shopping Center Norte está localizada na Vila Guilherme, na zona norte de São Paulo. Em 1984 era um antigo meandro do rio Tietê, que antes da sua retificação foi utilizado como lixão pela Prefeitura de São Paulo, nos anos de 1960.

Esses resíduos não foram removidos e serviram para aterrar a área durante a construção do Shopping, não estando determinadas sua distribuição espacial e volume. Como medida de segurança, durante a construção do Shopping, foram instalados respiros de gases subterrâneos, existindo relatos desses respiros em combustão durante a construção. Atualmente só existem respiros na calçada na área externa ${ }^{14}$.

Em 2004, o local passou a ser investigado e alertado sobre a exaustão do gás, entretanto, em 2010 foram identificadas concentrações de metano em níveis críticos, podendo se infiltrar nas edificações por meio de trincas e pisos com risco de explosividade.

Em 2011, o órgão ambiental notificou ao empreendimento que se não fosse realizado o controle do acúmulo do gás metano no subsolo, o local seria interditado (MORINAGA, 2013).

\subsubsection{Morro do Bumba}

Apesar de ser um exemplo externo à cidade de São Paulo, vale destacar o ocorrido no Morro de Bumba, localizado em Niterói, no estado do Rio de Janeiro. Em abril de 2010, após um período intenso de chuva na região, uma favela erguida sobre um lixão desativado acabou desmoronando e vitimando inúmeros moradores (MORINAGA, 2013).

\footnotetext{
${ }^{14}$ Disponível online em: https://cetesb.sp.gov.br/areas-contaminadas/2013/11/22/shopping-center-norte/. Acesso em: 26 out. 2019.
} 
Para esse caso, destaca-se que em 2004, o Instituto de Geociências da Universidade Federal Fluminense, havia feito um estudo a pedido do Ministério das Cidades e, constatou que a área possuía alto risco de acidentes, no qual foi exigido um monitoramento constante. No entanto, nada foi feito e o excesso de resíduos e a presença do gás agravaram a tragédia ${ }^{15}$, figura 20 .

Figura 20- Vista do deslizamento no Morro do Bumba, Niterói-RJ, em abril de 2010.

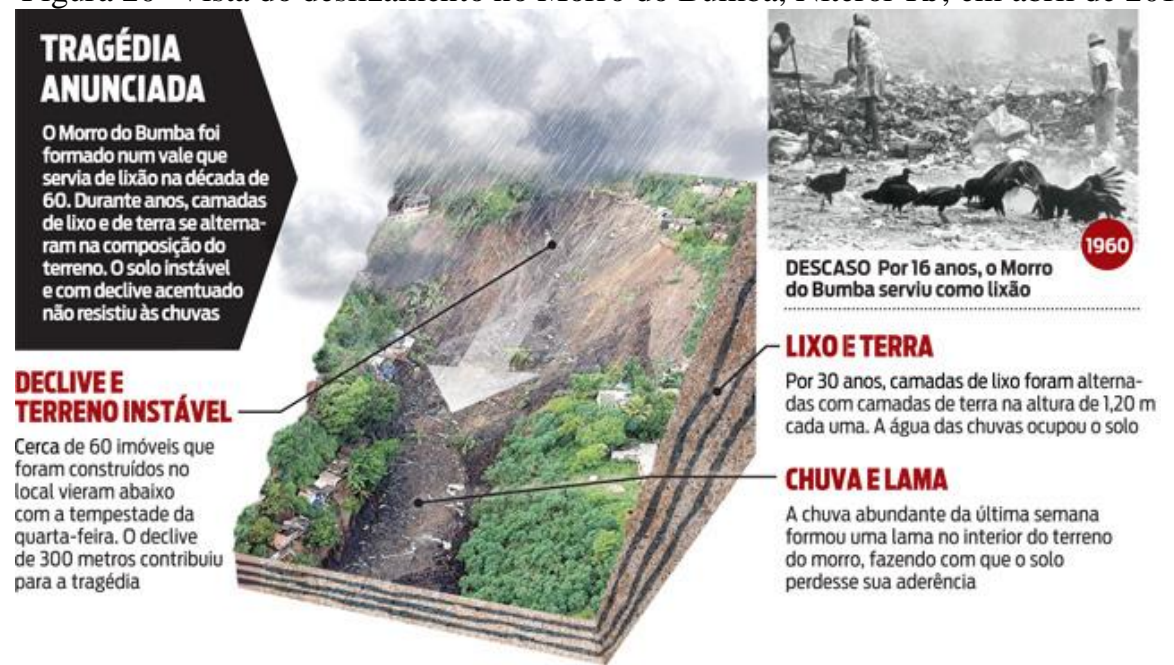

Extraído de: https://istoe.com.br/64153_A+MORTE+NO+LIXAO/. Acesso em: 28 ago. 2019.

Diante desses casos, fica evidente a importância de projetos e estudos detalhados para a reutilização de áreas contaminadas por resíduos, principalmente em função dos graves impactos que podem ocasionar à segurança humana e ao meio ambiente, seja em curto e/ou longo prazo.

\subsection{REQUALIFICAÇÃO DE ÁREAS CONTAMINADAS}

No Brasil, a maior parte de casos de recuperação de áreas contaminadas ainda é de postos de combustíveis, em função da legislação específica e as áreas industriais.

A prática de requalificação e reutilização desses espaços está principalmente voltada para a implantação de estabelecimentos comerciais, residenciais e de serviços, pela alta demanda de terrenos e por serem mais lucrativos, tanto na esfera pública como privada (SANCHES, 2014).

\footnotetext{
${ }^{15}$ Disponível online em: https://www1.folha.uol.com.br/cotidiano/2018/11/morrem-em-deslizamento-de-terraem-niteroi-no-rio.shtml. Acesso em: 25 nov. 2019.
} 
Entretanto, apesar de ainda ser um grande desafio para as cidades brasileiras de médio e grande porte, a conversão de áreas contaminadas em parques públicos no território urbano, não é muito explorada, pois há pouco conhecimento e entendimento sobre o potencial ecológico, social e econômico (SANCHES, 2017).

Contudo, antes de iniciar o assunto é necessário conceituar alguns termos aqui utilizados no contexto urbanístico para áreas contaminadas como reabilitação, remediação, revitalização e requalificação.

Segundo VARGAS (2014, p. 994) a reabilitação baseia-se em recuperar a área para tornar possível um uso qualquer. Já Box 1978 apud (BARROS, 2011, p. 205) define como o reuso do solo de um local alterado, de acordo com o projeto prévio e com a área circunvizinhança, visando outra finalidade.

VALENTIM (2005) expressa o termo como o modo de intervenção urbana voltado à superação dos passivos ambientais e econômicos resultantes do histórico industrial, sem a preocupação das externalidades negativas. A reabilitação teria como metas principais o desenvolvimento urbano sustentável e a devolução das áreas impactadas da cidade.

Nos casos em que é necessário utilizar a remediação em área contaminada, as ações selecionadas deverão estar contidas em um projeto e, durante sua execução, a área deverá estar sob monitoramento, assim definida pela (CETESB, 2001, p. 5):

[...] técnica ou conjunto de técnicas em uma área contaminada, visando à remoção ou contenção dos contaminantes presentes, de modo a assegurar uma utilização para a área, com limites aceitáveis de riscos aos bens a proteger.

A revitalização, termo empregado usualmente por arquitetos e urbanistas é caracterizado como promover sua vitalidade outra vez, ou seja, busca promover uma nova reocupação social e econômica considerando seu antigo uso. Normalmente enfatiza uma única atividade e a restauração de fachadas, muito usado com a finalidade turística (VARGAS, 2014).

É importante lembrar que revitalizar não é o mesmo que remediar a área contaminada, pelo contrário, é levar a um novo uso do solo ou mesmo à criação de um ambiente, totalmente diferente daquele que precedeu a contaminação de maneira segura, como por exemplo, um lago em uma antiga cava de mineração (SÁNCHEZ, 2004). 
No entanto, requalificar uma área contaminada significa promover a qualidade para um novo momento, de forma que atraia atividades. Implica em realizar intervenções físicas e de usos, podendo considerar o mercado e absorver as mudanças (VARGAS, 2014).

BARROS (2011) ressalta que é o termo bem mais adequado está voltado quanto à qualidade da paisagem e de vida nos parques urbanos em seus arredores.

A prática de requalificação de áreas contaminadas em muitos países vem sendo considerada como uma ferramenta sustentável para o uso e ocupação do solo no espaço urbano (GRIMSKI, 2004). Entretanto, SOUSA (2003) destaca que os esforços identificados têm sido feitos pelo poder público e estão relacionados com pesquisas, políticas públicas e financiamentos de diversos programas, buscando diminuir os custos e riscos associados às áreas degradadas e contaminadas, e estimulando a sua recuperação ambiental e urbanística (MORINAGA, 2017).

MARKER (2013) ressalta que as políticas públicas são essenciais para estimular a reabilitação de áreas contaminadas, pois caracterizam-se pela presença de fundos públicos, incentivos fiscais, mecanismos de cooperação entre setores públicos e privados, além da flexibilização da responsabilidade legal e da vinculação dos padrões de remediação aos usos pretendidos.

No entanto, para que se possa reutilizar um local de forma segura é necessário que a área tenha passado pelo gerenciamento de reabilitação de $\mathrm{AC}$, e tenha sido classificada como ACRu. Assim, posteriormente o órgão responsável municipal competente possa emitir as autorizações de demolição e construção, identificando qual será o uso pretendido da área (agrícola, residencial ou comercial/industrial), conforme instruído pela DD Nº38/2017/C (CETESB, 2017).

\subsubsection{Programas e Incentivos voltados a requalificação de áreas contaminadas}

Os Estados Unidos, foram os pioneiros na implementação de medidas para o gerenciamento e promoção de requalificação de áreas contaminadas. Para isso, a EPA elaborou e criou legislações específicas para à revitalização de todos os tipos de áreas contaminadas. 
A primeira legislação americana promulgada sobre o tema foi em 11 de dezembro de 1980, a Lei de Resposta Ambiental, Responsabilidade, Compensação (CERCLA) ${ }^{16}$, a qual entre outras medidas criou Programa Superfund de 1986, que é um fundo federal para a gestão de áreas contaminadas não controladas ou sem responsáveis identificados (chamadas de áreas órfãs) gerenciado pela EPA (USEPA, 2018).

Essa norma criou imposto sobre as indústrias de petróleo e química, concedendo à autoridade federal o dever de procurar as partes responsáveis por qualquer lançamento ou ameaça de liberação de substâncias perigosas, que possam colocar em risco a saúde pública ou o meio ambiente. $\mathrm{O}$ valor arrecadado é utilizado para a limpeza dos locais abandonados ou contaminados com resíduos perigosos (USEPA, 2018a).

A definição para utilização do Superfund obedece a uma ordem de prioridade de áreas com maior risco, de acordo com a National Priorities List (NPL), o qual se baseia na aplicação de uma metodologia para a pontuação e a classificação dos locais denominada de Hazard Ranking System (HRS) (MORINAGA, 2013).

As providências a serem tomadas pelo responsável legal podem ser de curto prazo com remoções imediatas, ou de longo prazo, que seriam processos de remediação sem risco eminente (CANÁRIO, 2018). Essa legislação também adota o princípio do poluidor-pagador, e atribui ao proprietário da área a responsabilidade pela remediação, mesmo que este não seja o causador da contaminação.

Com o intuito de alcançar seus objetivos a EPA estabeleceu programas e firmou parceiras com estados e municípios de outras agências federais. Estima-se que nos Estados Unidos existam mais de 450.000 locais abandonados e contaminados, número que pode chegar a um milhão (WERNSTEDT et al. 2013; ZHANG; KLENOSKY, 2016).

Entre os programas existentes destaca-se o Land Revitalization Program, que promove a integração sobre a reutilização sustentável em todas as decisões de limpeza e redesenvolvimento, transformando esses locais em ambientes produtivos, sustentáveis e acolhedores (USEPA, 2018b). Além do incentivo às comunidades para o processo de reutilização, a EPA destaca:

\footnotetext{
${ }^{16}$ CERCLA- Disponível Online: https:/www.epa.gov/enforcement/comprehensive-environmental-responsecompensation-and-liability-act-cercla-and-federal.CERCLA. Acesso em: 02 fev. 2019.
} 
Esses locais uma vez limpos, melhoram a qualidade ambiental, estimulam o desenvolvimento econômico, encorajam o envolvimento do público no planejamento de toda a área, revitalizam as comunidades com espaços verdes, além de aumentar a eficiência dos esforços de limpeza do local (USEPA, 2018c).

Outro programa americano voltado à reutilização de áreas contaminadas é o ATSDR's Brownfield/Land Reuse Health Program, cujo seu objetivo principal é a saúde das comunidades na reconstrução e revitalização dessas áreas (ATSDR, 2019).

O Programa de Saúde de Reutilização de Terras/Brownfield da ATSDR promove o envolvimento da comunidade, parcerias, comunicação e educação por meio de ações de saúde pública. São responsáveis por promover ambientes saudáveis e seguros, evitando exposições prejudiciais a contaminantes ambientais (ATSDR, 2019).

$\mathrm{Na}$ Europa, segundo o órgão ambiental European Environment Agency- EEA, os Estados-Membros possuem legislação específica para a proteção do solo, não ficando sujeitos a um conjunto abrangente e coerente de regras da União (EEA, 2014).

Entretanto, a EEA reúne informações sobre solo e áreas contaminados desde 1996, quando criou um centro conhecido hoje como European Soil Data Centre (ESDC). Esse centro busca ser o ponto de referência único e acolher todos os dados e informações relevantes do solo em nível europeu e contém vários recursos organizados e apresentados de várias maneiras: conjuntos de dados, serviços/aplicativos, mapas, documentos, eventos, projetos e links externos (EEA, 2019).

Dos trinta países-membros, trinta e nove mantêm inventários abrangentes para locais contaminados, sendo que vinte e quatro países possuem inventários de dados nacionais centrais, enquanto seis países (Bélgica, Bósnia-Herzegovina, Alemanha, Grécia, Itália e Suécia), gerenciam seus inventários em nível regional. Quase todos os inventários incluem informações sobre atividades poluidoras, locais potencialmente contaminados e locais contaminados (EEA, 2014).

$\mathrm{Na}$ Europa, também existe a CARBENET (Concerted Action on Brownfields and Economic Regeneration Network), uma rede europeia de peritos que abordam e discutem questões relacionadas à regeneração de brownfields (EUGRIS, 2006).

A CARBENET considera que a revitalização é um canal que pode abrir novas possibilidades para melhorar a reabilitação de locais abandonados das cidades europeias; promover o compartilhamento das experiências de toda Europa; propiciar novas estratégias de 
gestão e ferramentas inovadoras e contribuir diretamente para a melhoria da qualidade de vida população (EUGRIS, 2006; LINO; AQUINO, 2017).

Existem outras organizações e programas na Europa como a Contaminated Land Rehabilitation Network for Environmental Technologies (CLARINET), a Regeneration of European Sites in Cities and Urban Environmental (RESCUE), a Network for Industrially Contaminated Land in Europe (NICOLE) e a National Brownfields Sites Project (NBSP) (SANCHES, 2014).

No Reino Unido, a reutilização de áreas degradadas e/ou contaminadas é fortemente incentivada pelo governo. Entre 1988 e 1993, mais de 19\% dos locais abandonados foram convertidos em espaços verdes - mais do que qualquer outro uso final destinado às áreas degradadas do país UK DETR ${ }^{17}, 1998$ (apud SOUSA, 2003).

Além disso, existe o programa Campaign to Protect Rural England ${ }^{18}$ que incentiva a reutilização de brownfield, visando proteger as áreas verdes e rurais, assim como as áreas de greenfields.

Também tem a instituição CL:AIRE ${ }^{19}$ (Contaminated Land: Applications in Real Environments), uma organização independente sem fins lucrativos, criada em 1999 para estimular a regeneração de terrenos contaminados no Reino Unido, aumentando a conscientização e a confiança em tecnologias de remediação práticas e sustentáveis (CL:AIRE, 2019).

$\mathrm{Na}$ Inglaterra através da Agência de Desenvolvimento do Noroeste (Northwest Regional Development Agency), existem três grandes programas estratégicos de recuperação de áreas degradadas e criação de novos espaços verdes: Newlands, Remade e Revive, cujo o foco principal é a regeneração da terra de forma sustentável, o aumento e a melhoria da infraestrutura verde da região (SANCHES, 2011).

O programa Newlands ${ }^{20}$, lançado no verão de 2003 pela Forestry Commission visa recuperar grandes áreas de terras abandonadas, subutilizadas e negligenciadas nessa região. $\mathrm{O}$ objetivo principal é transformá-las em bosques, matas e áreas de preservação para

\footnotetext{
${ }^{17}$ UK DETR. Derelict Land Surveys in 1988 and 1993. Department of Environment, London. 1998.

18 Disponível online: https://www.cpre.org.uk/magazine/opinion/item/3736-putting-brownfield-firstovercomingbarriers-to-redevelopment. Acesso: 28 nov. 2019.

${ }^{19}$ Disponível online: https://www.claire.co.uk/home/about-us. Acesso em: 28 nov. 2019.

${ }^{20}$ Disponível online em: http://www.newlandsproject.co.uk/. Acesso em: 28 nov. 2019.
} 
comunidade local, proporcionando maiores atrações e atendendo às demandas sociais e econômicas (SANCHES, 2011; NEWLANDS, 2019).

O Remade (Reclamation and Management of Derelict land) coordenado pela prefeitura de Lancashire até 2011 tinha como meta de recuperar 300 ha de áreas degradadas (antigos sítios industriais, áreas de mineração e ferrovias desativadas, reservatórios em desuso (SANCHES, 2011).

E por último o Revive, que tem o objetivo de recuperar 170 ha de brownfields e converter em áreas verdes contribuindo para a infraestrutura verde de Cheshire e de Warrington. Dentre os projetos destaca-se a recuperação de um aterro Bewsey Tip (SANCHES, 2011).

Com base nos programas internacionais expostos é possível identificar que existem diversas maneiras de se aproveitar o potencial de reutilização das áreas contaminadas após intervenções necessárias, uma vez que podem apresentar algum passivo ambiental de risco (SILVA, 2016; LINO; AQUINO, 2017).

Entretanto no contexto brasileiro, as pesquisas e informações públicas no que tange as áreas contaminadas e sua revitalização em áreas verdes no contexto urbano são escassas, sendo necessários maiores esforços e investimentos nessa direção, como um primeiro passo para o conhecimento real da situação (SANCHES, 2014).

Segundo CANARIO (2018) em um levantamento realizado em portais institucionais dos órgãos ambientais dos vinte e sete estados do país, além do Distrito Federal, apenas três estados (São Paulo, Minas Gerais e Rio de Janeiro) dispunham de informações sobre áreas contaminadas, conforme exigido no Art. 38 da Resolução Conama 420/2009.

No entanto, o estado de São Paulo com a Lei Estadual $n^{\circ}$ 13.577/2009 instituiu a criação do Fundo Estadual para Prevenção e Remediação de Áreas Contaminadas - FEPRACfundo de investimento vinculado à Secretaria do Meio Ambiente e destinado à proteção do solo contra alterações prejudiciais às suas funções, bem como à identificação, remediação e reabilitação de áreas contaminadas. Porém, ainda o fundo não está sendo utilizado e cabe à CETESB as funções de agente técnico e de secretaria executiva do FEPRAC (SÃO PAULO (estado), 2009).

Deste modo, é possível identificar diversos benefícios que a revitalização de áreas contaminadas traz para o espaço urbano. Do ponto de vista ambiental pode minimizar a contaminação e recuperar o meio ambiente, evitando a progressiva utilização dos espaços livres para outros usos (GRIMSKI, 2004; HABERMAMM E GOUVEIA, 2014). 
É possível a reintegração ao ciclo econômico, podendo contrabalançar com a decadência social de alguns centros urbanos, melhorar ou recuperar as funções do solo e das águas subterrâneas, e ainda abrigar usos sociais urgentemente necessitados como parques, habitação social, praças públicas, entre outros (MARKER, 2013). Também cria oportunidades, negócios, empregos e gera impostos, e em termos de efeitos sociais, permite a requalificação de bairros e melhoria da qualidade de vida das pessoas (GRIMSKI, 2004).

Com isso, pode-se perceber que com o retorno de locais contaminados ao espaço urbano é possível aumentar os valores da propriedade, uma base tributária mais alta e espaço aberto protegido. Além disso, quando os interesses locais têm interesse na propriedade revitalizada, as chances são maiores de uso produtivo contínuo.

No entanto, SANCHES (2014) salienta que apesar das áreas contaminadas apresentarem um alto potencial para a criação de novas áreas como parques, áreas de lazer, recreação, proteção e conservação ambiental, ainda há pouco conhecimento e entendimento a respeito e que maneira geral, faltam pesquisas que forneçam embasamento sobre os benefícios dessas ações.

\subsection{EXPERIÊNCIAS PRÁTICAS INTERNACIONAIS DE REQUALIFICAÇÃO EM PARQUES}

A implantação de parques sobre áreas contaminadas por resíduos passou a ser discutido tanto no cenário nacional como internacional pelo seu grande desafio.

Essas áreas requerem, quase sempre, um maior tempo de planejamento e elaboração de projeto para convertê-las em parques, em função da sua complexidade e das características intrínsecas que estes locais apresentam. Em contrapartida, SANCHES (2014) ressalta que deixar essa porção de terra sem qualquer uso abandonada nas periferias da cidade, torna-a vulnerável a diversas atividades ilícitas ou a ocupação ilegal não sendo uma decisão sábia e nem rentável, além dos riscos à saúde humana.

Entre as tipologias de reuso (agricultura, residência ou lazer) as alternativas mais comuns e viáveis para requalificação desse tipo de áreas contaminadas é a transformação em parques. Isto se justifica em razão ao tamanho (espaços generosos), localização (próximo ou inserido na malha urbana), posição do entorno (áreas densamente ocupadas e com carência de vegetação) e o custo baixo (SANCHES, 2014). 
Os pesquisadores (HARIK et al. 2006) ressaltam que projetos de conversão de aterros desativados em parques não são uma solução nova. Os primeiros parques construídos em aterros nos Estados Unidos datam de 1916, com Rainer Playfield, antigo Rainier Dump, em Seattle, antes mesmo de surgir o termo aterro sanitário.

Os autores ainda afirmam que em outras situações, em uma área metropolitana mais densa, um aterro de resíduos talvez, seja a única área livre remanescente para a criação de áreas verdes (HARIK et al. 2006).

Segundo a USEPA 2002 (apud BARROS, 2017, p. 266), uma das dificuldades é em razão das grandes extensões e volumes da proporção da contaminação que normalmente se apresentam nesses locais, o que inviabiliza muitas vezes economicamente o processo de remediação e o tratamento do solo contaminado. Mas, a partir da década de 1970, foram realizados projetos pontuais e bem-sucedidos da conversão de áreas degradadas e contaminadas em áreas verdes e parques. No entanto, políticas públicas e ações de requalificação de forma estratégica e dentro da cidade são relativamente recentes (SANCHES, 2014).

A seguir serão apresentados projetos de requalificação e experiências de sucesso, tanto nacionais como internacionais, de áreas contaminadas por resíduos. Apesar de pontuais, demonstram diferentes formas de revitalização em áreas verdes ou parques públicos, beneficiando a comunidade como um todo.

\subsubsection{Aterro Brick Township x Painel Solar- Estados Unidos}

O aterro sanitário municipal, em Brick Township Nova Jersey, Estados Unidos começou sua operação por volta da década de 1940 até 1973. Este aterro recebeu materiais oriundos de esgotos e líquidos contaminados, o que acarretou na contaminação das águas subterrâneas. Seu encerramento ocorreu em 1979, e foi adicionado em 1983 à lista de prioridades nacionais da EPA para sua limpeza (USEPA, 2018d). 
Na década de 1990, uma pluma de água contaminada subterrânea foi encontrada em uma área de cerca de $470 \mathrm{acres}^{21}$, onde foi constatado que era proveniente do aterro (USEPA, 2018e). Posteriormente, em 2007 a EPA assumiu o caso e realizou o trabalho de limpeza no local, que foi concluído em 2013.

Buscando evitar mais contaminação da água subterrânea, a EPA exigiu que a Brick Township instalasse uma tampa impermeável no aterro para evitar que a água da chuva se infiltrasse no solo do aterro sanitário. Além disso, exigiu do município um programa de monitoramento de águas subterrâneas a longo prazo, que ainda está em andamento (USEPA, 2018d; USEPA, 2018e). Também foram solicitadas outras restrições estaduais e locais para evitar que a água subterrânea contaminada do local seja usada como água potável.

Deste modo, Brick Township decidiu transformar esse antigo aterro em uma instalação de energia solar (figura 21) que agora está concluída e é grande o suficiente para fornecer a eletricidade usada pelos edifícios do governo municipal e parques comunitários do entorno.

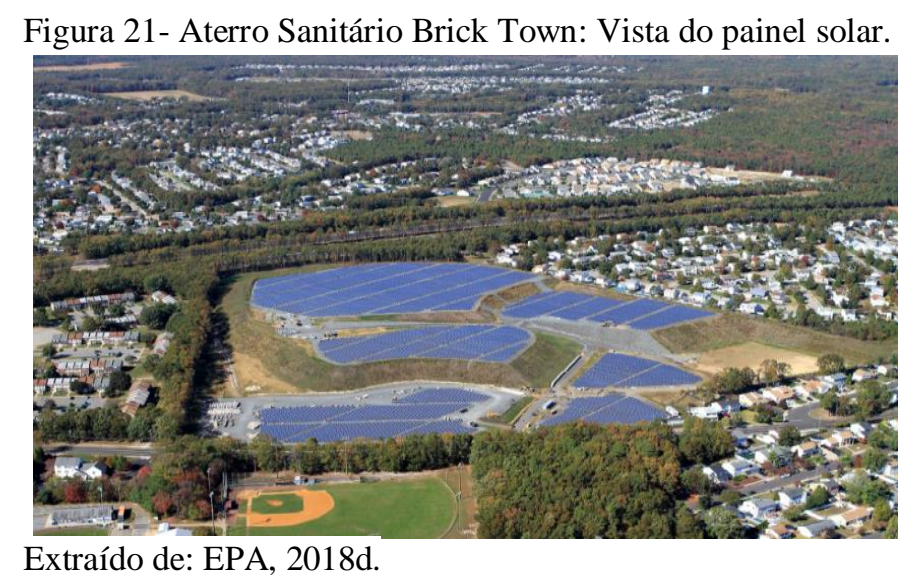

\subsubsection{Aterro Hiriya x Parque Ariel Sharon- Israel}

Em Tel Aviv, Israel, o antigo aterro sanitário Hiriya faz parte de um dos maiores projetos de reabilitação ambiental do mundo- o futuro Parque Ariel Sharon, elaborado pelo paisagista alemão Peter Latz e Partner Gbr. Esse paisagista é um grande profissional e já possui ampla experiência em projetos de parques e áreas verdes.

\footnotetext{
21 Unidade para medir área utilizada no sistema tradicional dos Estados Unidos. Uma unidade equivale a $4,047 \mathrm{~m}^{2}$. Disponível on-line: https://dictionary.cambridge.org/pt/dicionario/ingles-portugues/acre. Acesso em 06 fev. 2019.
} 
$\mathrm{O}$ antigo aterro situa-se na confluência dos rios Ayalon e Shapirim e a principal atração é a montanha de resíduos sólidos (figura 22) que ali se acumulou desde 1952, totalizando uma altura de 80 metros até o ano 2000, quando foi decretado o fim da atividade (BARROS, 2011; SANCHES, 2014). Em função da enorme elevação da montanha com cerca de 16 milhões $\mathrm{m}^{3}$ de resíduos depositados ${ }^{22}$, seu processo de recuperação iniciou em 2001.

Figura 22- Antigo aterro sanitário e a montanha de resíduos Hiriya.

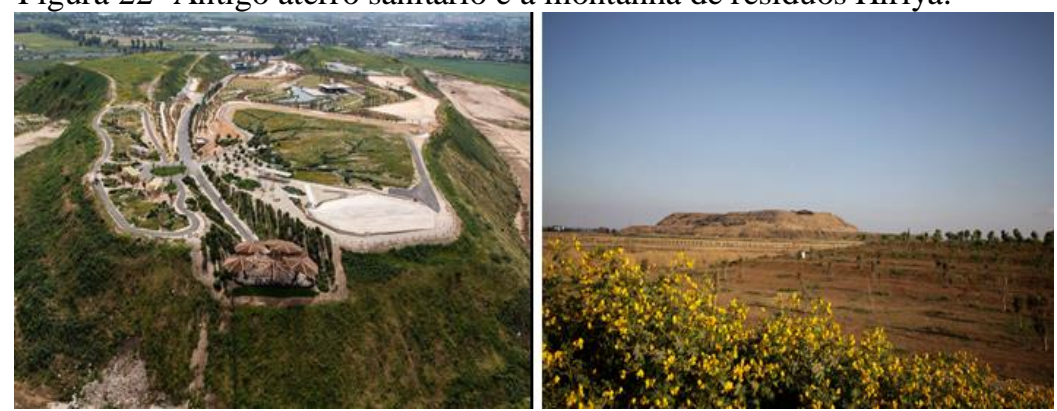

Extraído de: PETER LATZ+ PARTNER ${ }^{23}$.

O local deverá ser transformado em um símbolo ambiental e parque temático sobre reciclagem para crianças, além de ser um parque ecológico que já está parcialmente em funcionamento.

Três estações de reciclagem já funcionam na base da montanha, triturando o resíduo processado e transformando-o em cascalho, e a matéria orgânica seca, em matéria vegetal decomposta. Ainda em fase experimental, uma inovação de uma empresa israelense está testando em separar o resíduo residencial comum por meio de piscinas de água (SANCHES, 2014; www.parksharon.co.il/). Os gases estão sendo coletados em poços escavados na montanha, e em breve serão vendidos para cumprir os acordos do protocolo de Kyoto referente aos créditos de carbono. A ideia é que a energia gerada pela montanha produza iluminação do parque durante a noite (SANCHES, 2014).

Após sua total recuperação, prevista para 2020, na área será incorporada uma vasta área natural denominada de Parque Ayalon (figura 23), transformando-se em um dos maiores parques urbanos mundiais ${ }^{24}$.

\footnotetext{
${ }^{22}$ Disponível online em: http://www.parksharon.co.il/html5/?_id=9282\&did=10116\&G=9051\&SM=9282. Acesso em: 20. Nov. 2019

${ }^{23}$ Idem ao 16.

24 Disponível online em: https://www.latzundpartner.de/en/projekte/klassische-landschaften/park-ariel-sharontel-aviv-il/. Acesso em: 20 nov. 2019.
} 
Figura 23- Rio Ayalon e o Parque Ariel Sharon.

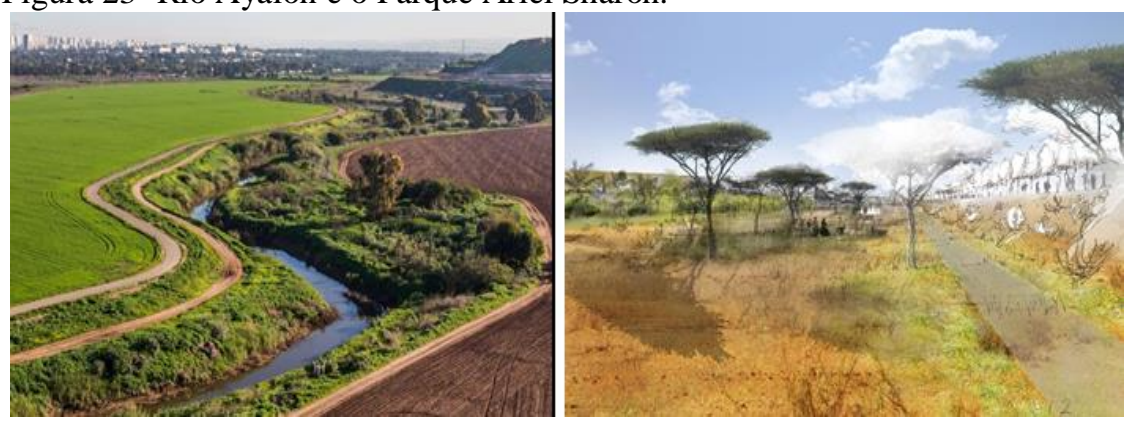

Extraído de: PETER LATZ+ PARTNER.

\subsubsection{Aterro de Beirolas x Parque Tejo- Portugal}

Em Lisboa, Portugal, o complexo do Parque das Nações ${ }^{25}$, compreende o Parque Tejo, implantado sobre o antigo aterro de Beirolas.

O Parque das Nações abrange uma área de 340 ha, numa faixa de $5 \mathrm{~km}$ na frente ribeirinha do estuário do Rio Tejo, integrado numa área de 60 ha, ao redor da Doca dos Olivais. A oportunidade de criação deste ambicioso projeto surgiu com a candidatura de Lisboa à organização da última grande exposição mundial do séc. XX, a EXPO'98 26 .

O evento representou uma grande oportunidade para promover esta operação de requalificação urbanística e ambiental, pois a área registrava um avançado estado de degradação ambiental. Sua ocupação era predominantemente industrial, caracterizada por ausência de legislação ambiental e critérios de ordenamento do solo, assim como em situações de controle de utilização clandestina (EXPO, 1998).

Os usos anteriores realizados na área foram as grandes infraestruturas industriais, os depósitos de produtos petrolíferos (ocupando cerca de 50 ha), o depósito geral de material de guerra, a estação de tratamento de águas residuais, o aterro sanitário e a estação de tratamento de resíduos sólidos de Beirolas, além de diversas instalações portuárias e atividades afins, (figura 24).

\footnotetext{
${ }^{25}$ Disponível online: http://www.portaldasnacoes.pt/. Acesso em: 10 nov. 2019.

${ }^{26}$ Disponível online: http://www.portaldasnacoes.pt/item/expo-98-2/. Acesso em: 10 nov. 2019.
} 
Figura 24- Empresas Petrolíferas e o Parque das Nações.
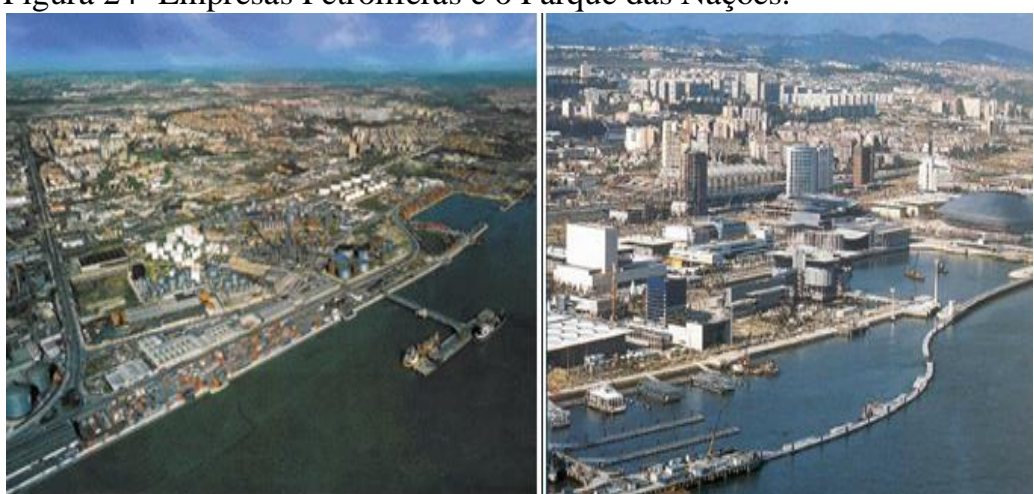

Extraído de: <http://www.portaldasnacoes.pt/item/solos-das-petroliferas-aterro-sanitario-de-beirolas/>. Acesso em: 20 nov. 2019.

O projeto compreendia seis zonas para quais foram elaborados estudos mais detalhados e executados por diferentes arquitetos. O Plano de Intervenção do Parque Tejo e Trancão abrange a faixa ribeirinha e uma zona verde ao longo dos rios, a qual ficou delegada às atividades de lazer, esportes e educação ambiental (MORINAGA, 2007).

O Aterro de Beirolas situa-se no extremo norte do Parque das Nações, entre o rio Trancão e a Estação de Tratamento de Águas Residuais de Beirolas com área original de 17 ha e 15 metros de altura (BARROS, 2011).

Entre os anos de 1985 a 1990, este aterro serviu como local preferencial para a deposição de resíduos sólidos de Lisboa. Foi utilizado durante um período superior ao inicialmente previsto, e posteriormente apresentou problemas no funcionamento dos sistemas de drenagem de lixiviados e biogás que haviam sido projetados, bem como estabilidade dos taludes do aterro.

Os primeiros estudos de diagnóstico realizados foram nos locais onde se instalavam as companhias petrolíferas, desde os anos 40. Foi identificado a presença pontual de hidrocarbonetos acima dos valores permitidos para uso residencial do terreno. Ao mesmo tempo, os resultados confirmaram que as características geológicas (camada argilosa) do local eram favoráveis e serviram de barreira natural à migração de contaminantes em profundidade ${ }^{27}$.

\footnotetext{
${ }^{27}$ Disponível online em: http://www.portaldasnacoes.pt/item/solos-das-petroliferas-aterro-sanitario-de-beirolas/. Acesso em: 20 nov. 2019.
} 
Também foi detectado que a contaminação do solo não ultrapassou, de 2 metros em profundidade, tendo-se estimado em cerca de $250.000 \mathrm{~m}^{3}$ o volume total de solos a necessitar de tratamento.

Para o solo contaminado com hidrocarboneto, a solução adotada foi a retirada do solo e utilização como material de enchimento na remodelação dos taludes, em célula confinada. Durante a escavação do solo, foi instalada no local uma estação de tratamento de águas residuais móvel para tratamento das águas subterrâneas e a recuperação de fase livre, constituída de subprodutos de petróleo que flutuam sobre o lençol de água subterrânea (MORINAGA, 2007).

Para os resíduos inertes resultantes das demolições, foram adotados mecanismos de reciclagem simples no local, levando esses resíduos aos empreiteiros para reutilizarem como matéria-prima nas futuras obras de construção. Este processo de reciclagem envolveu cerca de 812 mil toneladas de concreto e 190 mil toneladas de material de alvenaria, reutilizados em novas edificações.

A quantidade de aço resultante da separação do concreto rendeu 5 mil toneladas que foram levadas à fundição para transformação adequada. Os materiais ferrosos, e outros cuja reciclagem não foi possível na instalação existente no Parque das Nações foram processados em unidades exteriores.

Outras medidas da recuperação ambiental, foram realizadas como: a reconformação dos taludes do aterro, de forma a garantir a sua estabilidade; coleta e tratamento dos lixiviados; coleta e tratamento do biogás, com a queima ou o aproveitamento da energia extração; contenção dos resíduos, mediante a aplicação de membrana impermeabilizante; instalação do sistema de drenagem de águas superficiais; colocação de camada de solo para o plantio de espécies vegetais, constituindo-se no Parque Urbano do Tejo ${ }^{28}$.

De acordo com o plano de urbanização decorrente da Expo'98, cerca de 500 árvores existentes nos terrenos do Parque das Nações fazem parte das zonas verdes que foram transplantadas (figura 25). Ainda para melhorar a qualidade do solo, foi utilizado o lodo proveniente da estação de tratamento de águas residuais e o composto orgânico resultante do tratamento dos resíduos de Beirolas (EXPO, 1998).

\footnotetext{
${ }^{28}$ Idem ao 25.
} 
Figura 25- Parque Tejo com árvores transplantadas.
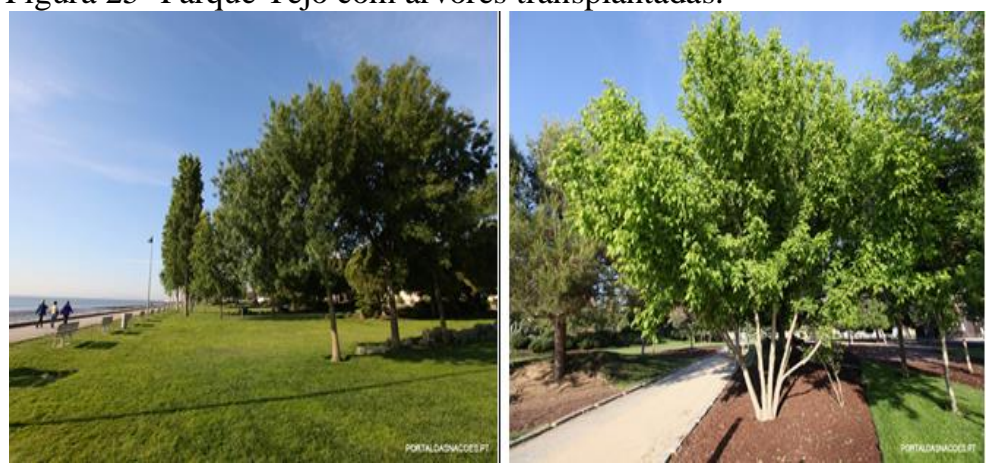

Extraído de: <http://www.portaldasnacoes.pt/item/parque-tejo>. Acesso em 20. Nov. 2019.

E de modo a garantir a continuidade de uma adequada qualidade ambiental das ações programadas e das medidas corretivas, foi instituído o Plano de monitoramento abordando os seguintes indicadores: qualidade dos solos; água subterrânea; águas superficiais e sedimentos; poluição atmosféricas; ruídos; geologia; meteorologia; comunidades biológicas e outros aspectos socioeconômicos (MORINAGA, 2007).

\subsubsection{Aterro Freskills x Parque Freskills- Nova York}

O Parque Freskills, em Nova York, ainda se encontra em andamento e compreende uma área de 2.220 hectares, o triplo da área do Central Park Manhattan. Da área total, 45\% pertencem ao aterro e os $55 \%$ restantes são ocupados por rios, áreas de várzeas e campos ${ }^{29}$.

O objetivo é transformá-lo no maior parque desenvolvido na cidade de Nova York em mais de cem anos, tornando-se um símbolo de renovação e expressão de como a sociedade pode restaurar o equilíbrio de sua paisagem (SANCHES, 2014).

A construção do parque está sendo gradualmente em fases, e a maior parte do local está fechado ao público com previsão de inauguração até 2036. As obras dos primeiros anos visam garantir o acesso do usuário ao interior do parque, em áreas já recuperadas como brejos, alagados, campos e córregos.

No início dos anos 1900, a área do aterro era um riacho e um estuário de água doce na parte oeste da cidade de Staten Island, na cidade de Nova York. O nome "Freshkills" vem da palavra holandesa do meio kille, que significa "leito do rio" ou "canal de água".

\footnotetext{
${ }^{29}$ Disponível online: https://www.nycgovparks.org/parks. Acesso em 20 nov. 2019.
} 
O aterro foi estabelecido pelo comissário de parques Robert Moses e a sua ideia inicial era manter aberto por cerca de três anos, enchendo as áreas úmidas no local de 450 acres para prepará-lo para o desenvolvimento, no qual iniciou sua operação em $1948^{30}$.

Em 1955, era considerado o maior do mundo, servindo como principal aterro sanitário para resíduo doméstico coletado na cidade de Nova York. Passou a crescer para 1.284 acres em 1961 (figura 26), e nessa época, a cidade de Nova York anunciou que o despejo em Freshkills continuaria por mais 15 anos, tendo, posteriormente, recebido metade dos resíduos gerados na cidade.

Figura 26- Aterro Freskills antes da implantação e após em operação.

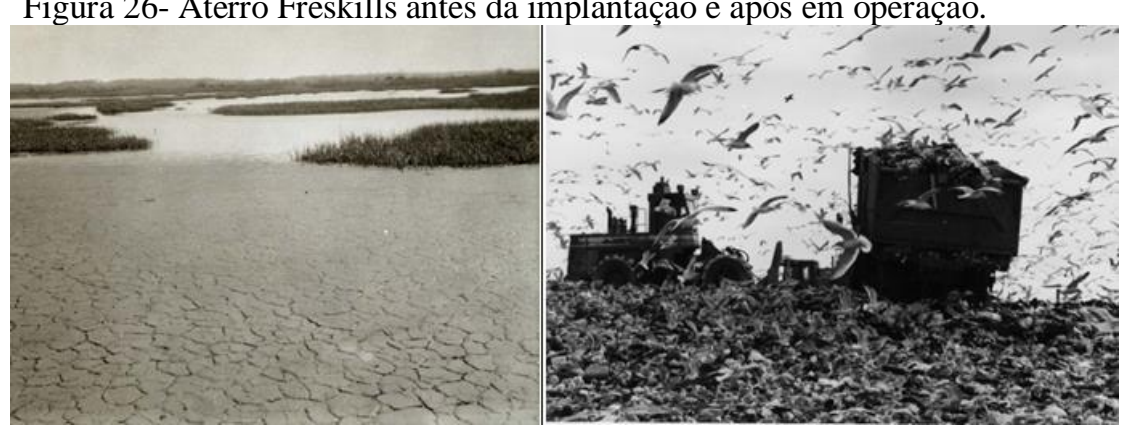

Extraído de: http://timeline.freshkillspark.org/. Acesso em 20 nov. 2019.

No auge de sua operação, FreshKills recebia até 29.000 toneladas de lixo por dia e empregava 680 pessoas. Quando o aterro sanitário Edgemere em Queens, foi fechado em 1991, o FreshKills se tornou o único aterro ativo na cidade de Nova York. Em 1996, uma lei estadual de Nova York foi aprovada exigindo que o aterro deixasse de aceitar resíduos sólidos até 31 de dezembro de 2001. Ele recebeu sua última barcaça de resíduos em 22 março de 2001, figura 27.

Em 1997, dois dos quatro montes de resíduos estavam fechados e cobertos com uma tampa que é constituída por camadas de solo, geotêxtis e geomembrana para estabilizar os resíduos enterrados e evitar a liberação do gás metano para atmosfera. Juntamente com a tampa existe um conjunto de valas, calhas e tanques de retenção para coletar e gerenciar as águas pluviais, evitando erosão na tampa (figura 28).

\footnotetext{
${ }^{30}$ Disponível online: http://timeline.freshkillspark.org/. Acesso em 20 nov. 2019.
} 
Figura 27- Aterro Freshkills no ano de fechamento em 2001.

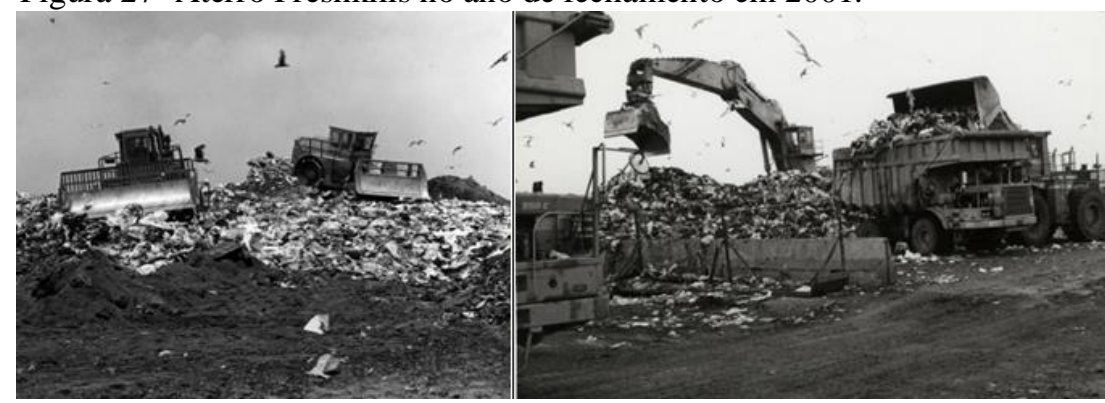

Extraído de: http://timeline.freshkillspark.org/. Acesso em 20 nov. 2019.

Figura 28- Montes Sul e Norte do Aterro FreshKills, fechado em 1997.

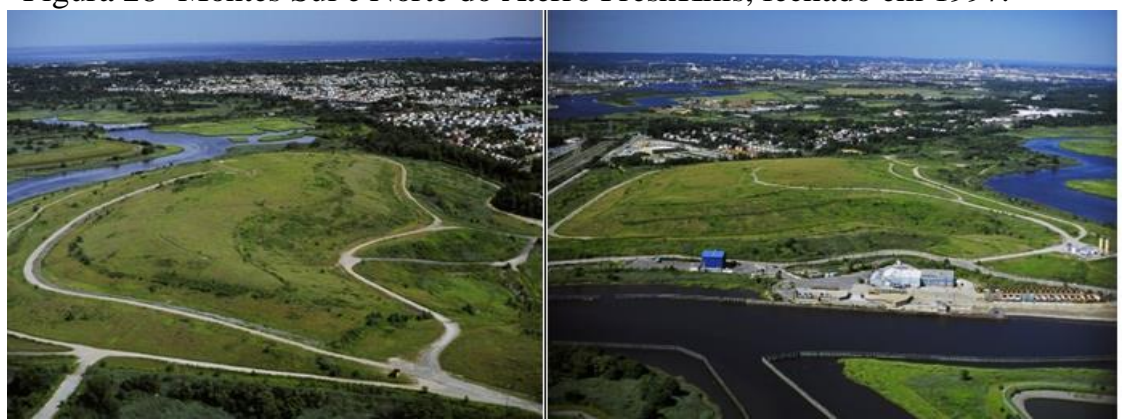

Extraído de: http://timeline.freshkillspark.org/. Acesso em 20 nov. 2019.

Os montes restantes pararam de aceitar resíduos em 2001. Seu limite começou em 2007, o monte leste foi limitado em 2011 e o último remanescente oeste, deve ser concluído em 2021. Os resíduos sólidos urbanos foram depositados em Freshkills por 53 anos.

O solo argiloso que ocorre naturalmente na parte inferior da camada de resíduos ajuda a impedir a migração vertical de lixiviado. Em 2006, foi anunciado o plano diretor do Parque Freskills pelo Departamento de Parques e Recreação. Esse documento apresenta o processo, o planejamento, zoneamento e as diretrizes para cada etapa do projeto (SANCHES, 2014).

O parque foi estruturado em três principais eixos: circulação- voltado às atividades de rotas para pedestres, ciclistas, trilhas e cavalgadas; biodiversidade pretende-se restaurar ecologicamente os hábitats e criação dos corredores ecológicos com áreas naturais e flora nativa; e programas para usos de lazer e recreação com atividades sociais culturais, artísticas e práticas esportivas como canoagem, como ilustra a figura 29 (SANCHES, 2014).

Além disso, existe um compromisso do governo com a produção de energia renovável para suprir a demanda interna do parque. No momento, o gás metano gerado pelo aterro, que é suficiente para aquecer 22 mil unidades habitacionais, já está sendo vendido para empresa a National Grid, responsável pela distribuição de energia e gás para a região de Nova York (SANCHES, 2014). 
Figura 29- Parque Freshkills.

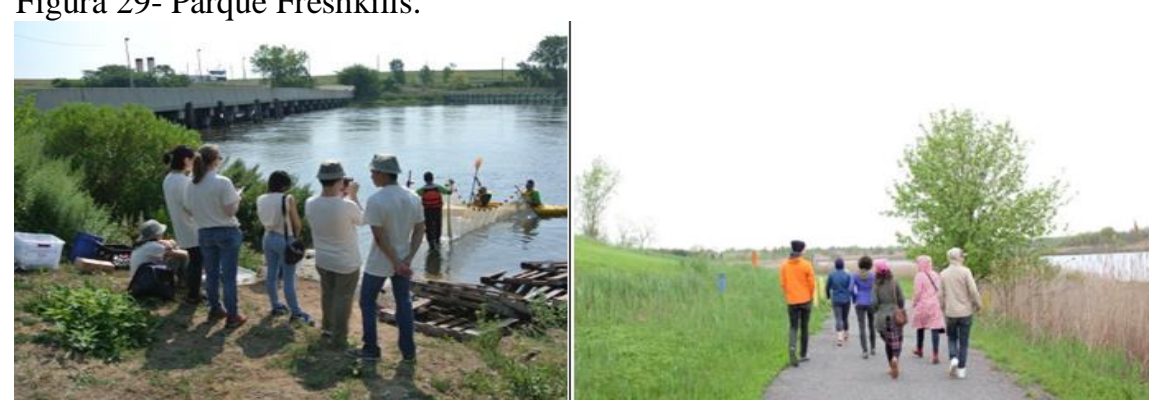

Extraído de: https://www.nycgovparks.org/parks/freshkills-park/photos. Acesso em: 20 nov. 2019.

\subsubsection{Aterro Semaku x Ilha Pulau Semaku- Cingapura}

Em Cingapura, o governo criou um aterro sanitário em uma antiga vila de pescadores, transformando em uma reserva natural. Pulau Semakau, como foi denominado, é o primeiro depósito de lixo na costa, figura 30 (PORTELLA e RIBEIRO, 2014).

Figura 30- Ilha Pulau Semaku e a barcaça transportando os resíduos.

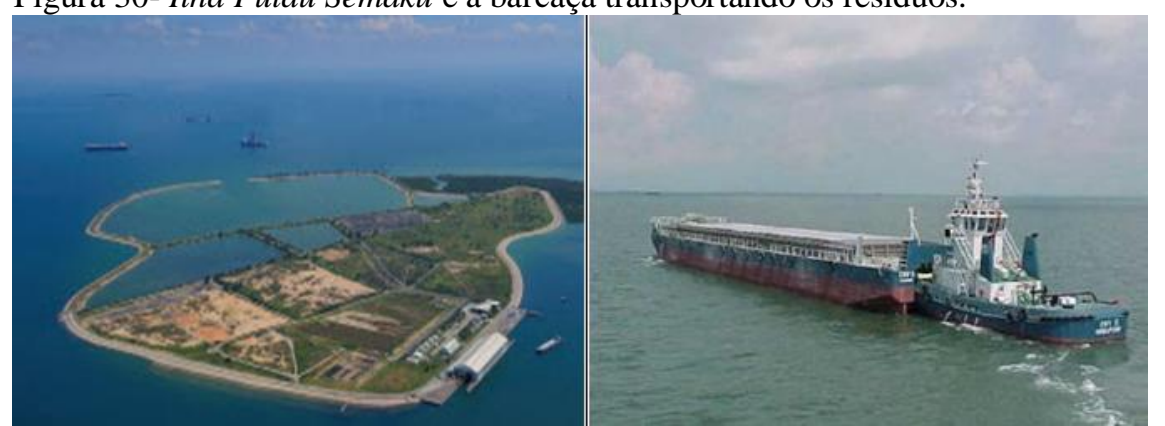

Extraído de: https://www.nea.gov.sg/our-services/waste-management/semakau-landfill. Acesso em: 25 nov. 2019.

O aterro sanitário de Semakau está localizado aproximadamente a $8 \mathrm{~km}$ ao sul de Cingapura ${ }^{31} \mathrm{e}$ incinera em torno 9,8 milhões de toneladas de lixo. A conversão da área em reserva natural, se deu no início da década com as instalações de US\$ 360 milhões de uma barreira impermeável de $7 \mathrm{~km}$ (composta por pedra, areia, argila e geomembrana de polietileno) no entorno da ilha, onde ficam estocadas as cinzas (PORTELLA e RIBEIRO, 2014).

${ }^{31}$ Disponível online: https://www.nea.gov.sg/our-services/waste-management-/semakau-landfill. Acesso em 25 nov. 2019. 
O lixo incinerado do continente chega em barcaças, e a cinza molhada é esvaziada em fossos para um dia serem cobertos de terra, onde palmeiras e outras plantas crescem naturalmente.

Destaca-se que a quantidade de resíduos sólidos descartados em Cingapura cresceu cerca de sete vezes por dia, de 1.260 toneladas em 1970 para um pico de 8.559 toneladas em 2016. Entretanto, antes da coleta de resíduos sólidos, os recicláveis são classificados e recuperados para processamento e valorização. Já os demais resíduos sólidos são coletados e enviados para as usinas de transformação de resíduos em energia pela incineração. A incineração reduz o volume de resíduos sólidos em cerca de $90 \%$ e produz vapor que promove a geração de eletricidade.

A incineração para Cingapura é de extrema importância, pois é escassa em terra para a implantação de futuros aterros sanitários, criando, assim, uma estrutura de gerenciamento de resíduos sustentável. ${ }^{32}$

As cinzas incineradas e outros resíduos não incineráveis são então transportados para a Estação de Transferência Marinha de Tuas para a operação de escavação no aterro sanitário de Semakau, onde são descartados.

Semakau é o único aterro ativo que recebe lixo incinerado, e ao mesmo tempo, que dá suporte a um ecossistema florescente, que conta com 700 tipos de plantas e animais de várias espécies ameaçadas (PORTELLA e RIBEIRO, 2014).

Existe um recife de coral ao longo da costa com abundante vida marinha e, no seu interior, pássaros e mangroves como a garça Ardea sumatrana e Tarambolas da Malasia que se reproduzem na ilha (BARROS, 2011; PORTELLA e RIBEIRO, 2014). A visita à ilha é permitida durante o dia e a noite com acompanhamento de um guia.

\subsubsection{Aterro de Adelaide x Parque Chambers Gully- Austrália}

O Parque Chambers Gully localizado no subúrbio de Adelaide, na Austrália, era um aterro local. A recuperação da área foi realizada através da ação conjunta de voluntários e com o auxílio de fundos governamentais.

\footnotetext{
${ }^{32}$ Disponível online: https://www.nea.gov.sg/our-services/waste-management/solid-waste-managementinfrastructure. Acesso em: 25. Nov. 2019.
} 
A área hoje é um santuário para a vida selvagem, incluindo principalmente cangurus e os coalas que são frequentemente vistos empoleirados nos eucaliptos do parque (figura 31), além de poder realizar uma trilha com circuito de $9,6 \mathrm{~km}$ com duração de 3 horas $^{33}$.

O circuito não pode ser acessado diretamente por estrada, mas é uma caminhada fácil de 1,2 km para chegar a um ponto de acesso, a partir do estacionamento de Chambers Gully.

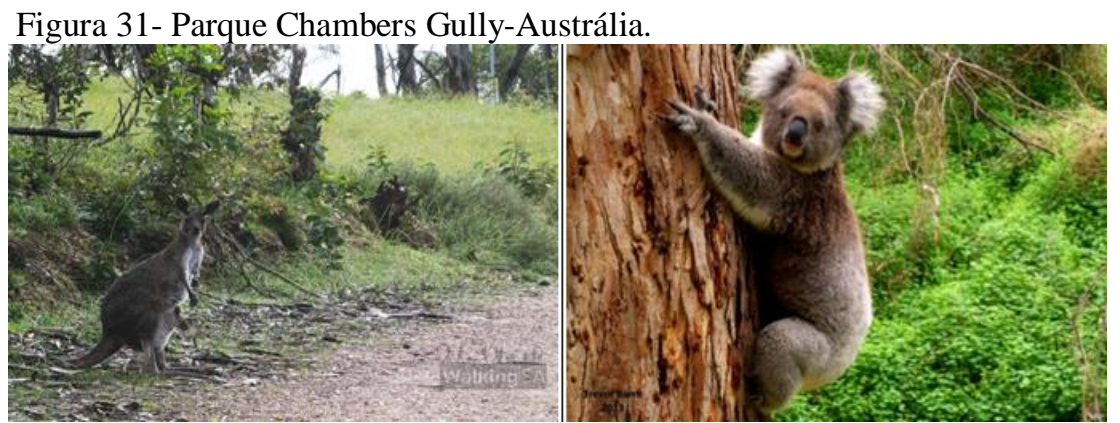

Extraído de: https://www.walkingsa.org.au/walk/find-a-place-to-walk/chambers-hike/. Acesso em: 25 nov. 2019.

\subsubsection{Lixão x Parque Tianjin Qiaoyuan- China}

Através do projeto regenerativo e da mudança do uso e ocupação do solo, o processo natural de adaptação de plantas e evolução da comunidade, promoveu a transformação de um antigo depósito de lixo em um parque urbano com 54 acres de baixa manutenção, na cidade costeira do norte de Tianjin, na China, figura 32.

Figura 32- Área antes da revitalização e o Parque Qiaoyuan.

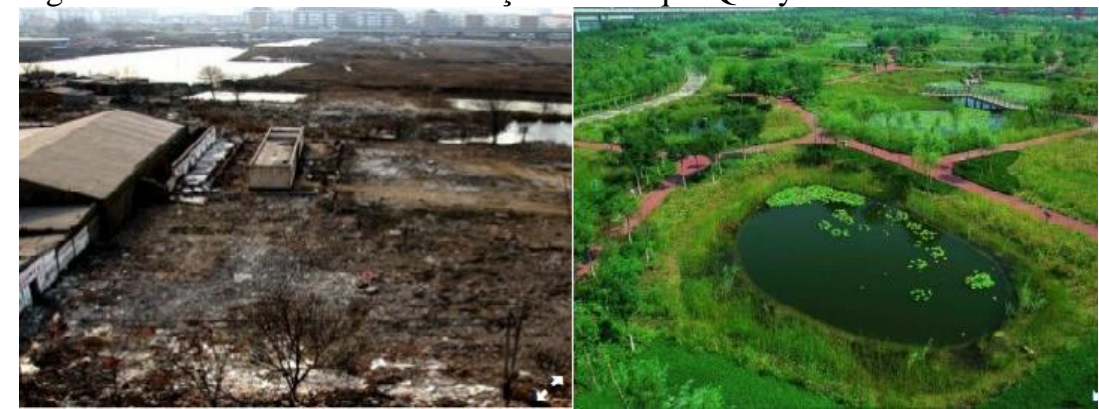

Extraído de:https://www.landscapeperformance.org/case-study-briefs/tianjin-qiaoyuan-park. Acesso em: 28 nov. 2019.

33 Disponível online: https://www.walkingsa.org.au/walk/find-a-place-to-walk/chambers-hike/. Acesso em 25 nov. 2019. 
$\mathrm{Na}$ área foi realizada a prática de tiro e com a rápida urbanização transformou-se em um depósito de resíduos e um poço inundado (figura 33) de várias conexões de águas pluviais urbanas. O solo fortemente contaminado e bastante salino e alcalino tornou-o um ambiente desafiador para as plantas Também era um local deserto e cercado de favelas e estruturas temporárias e precárias, que haviam sido demolidas antes do projeto ser realizado ${ }^{34}$.

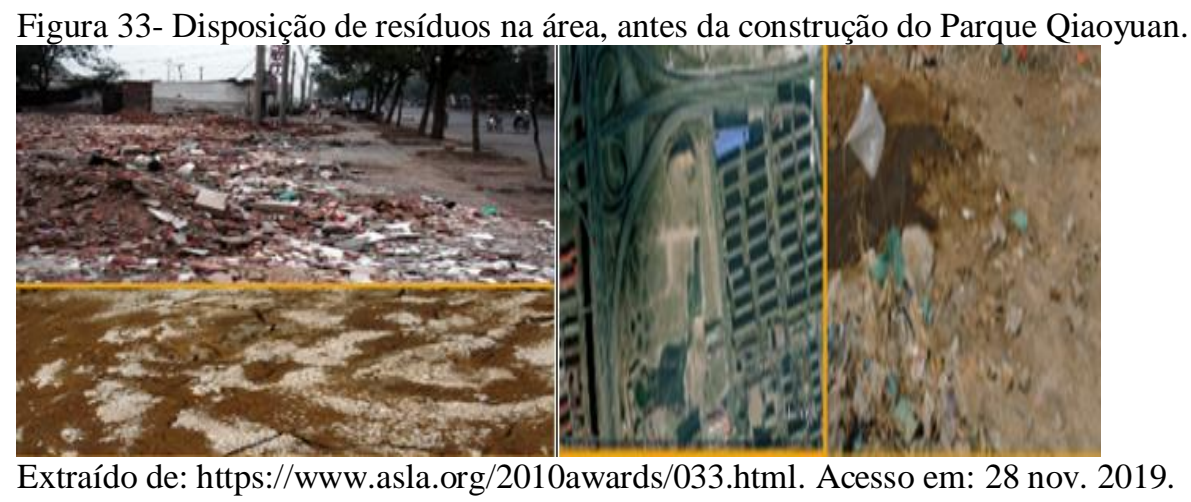

Historicamente, esta região costeira ao longo do Golfo de Bohai era rica em pântanos e salinas, a maioria das quais foram destruídas por décadas de desenvolvimento urbano. Em resposta às solicitações dos moradores para a limpeza do local, o governo municipal de Tianjin, no início de 2003, decidiu criar um parque que atendesse aos moradores do entorno, melhorasse as condições ambientais e exigisse pouca manutenção ${ }^{35}$.

Desta forma, embora fosse difícil cultivar árvores no solo salino-alcalino, foi desenvolvida uma solução para este parque, denominada de Paletas de Adaptação, projetada para permitir que a natureza funcionasse. Então, foi elaborada uma estratégia simples de projeto regenerativo da paisagem, que incluía 21 cavidades de diferentes tamanhos e profundidades, com algumas abaixo do nível do solo e outras acima em montes.

O resultado é uma mistura de lagoas de água, pântanos, piscinas sazonais e cavidades secas, que são alimentadas por chuvas e águas subterrâneas. Os solos nas cavidades secas são aprimorados pelos efeitos de lavagem e filtragem das chuvas sazonais, enquanto os lagos mais profundos capturam o escoamento e os nutrientes das águas pluviais.

\footnotetext{
${ }^{34}$ Disponível online: https: https://www.asla.org. Acesso em: 28 nov. 2019.

${ }^{35}$ Disponível online: https://www.landscapeperformance.org/case-study-briefs/tianjin-qiaoyuan-park-theadaptation-palettes. Acesso em: 28 nov. 2019.
} 
Sementes de espécies mistas de cobertura do solo e zonas úmidas e espécies nativas foram semeadas em vários trechos de vegetação, criando uma paisagem nativa de baixa manutenção, mista e de estética única.

Os visitantes aproveitam o parque seguindo caminhos de asfalto de cor vermelha que tecem as paletas com sinais interpretativos e plataformas de madeira (figura 34) que se estendem para as lagoas e cavidades ao meio da vegetação.

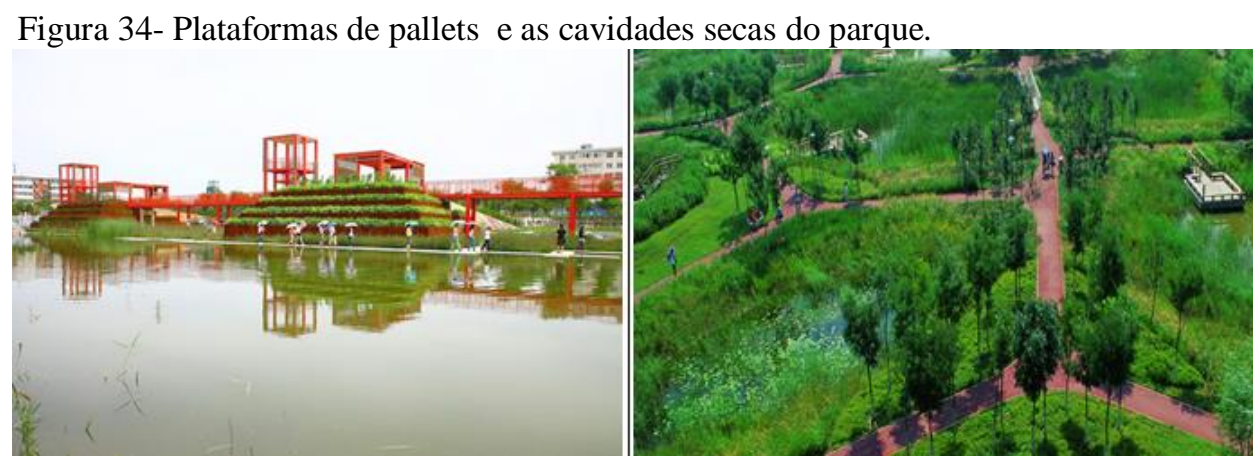

Extraindo de: https://www.asla.org/2010awards/033.html. Acesso em: 28 nov. 2019.

Atualmente, o parque executa diversos serviços para a cidade com a natureza presente, incluindo: a contenção e a purificação de águas pluviais; diversos tipos de vegetação; áreas de lazer e espaços verdes para a população de 20 mil habitantes que mora no entorno; melhoramento do solo salino-alcalino; oportunidades de educação ambiental para comunidade; redução de nível de ruído de $70 \mathrm{~dB}$ para 50dB; melhora da consciência ambiental e ecológica; e teve uma economia de aproximadamente US\$25.500 em custos com madeira, reutilizando 84,5 metros cúbicos de velhos trilhos de trem na construção das plataformas e pontes de observação.

Nos dois primeiros meses de sua abertura, de outubro a novembro de 2008, cerca de 200.000 pessoas visitaram o parque. É um parque de sucesso que muda de paisagem ao longo do período do ano, constantemente visitado pela comunidade, e precisa de pouca manutenção.

\subsubsection{Aterro Controlado Bowers x Parque Bowers - Estados Unidos}

O parque de Bowers localiza-se no distrito de Pickaway, ao norte de Circleville, estado de Ohio, próximo ao rio Scioto. A área possui 12 acres de superfície e teve origem em 
uma pedreira, que posteriormente em 1958, foi utilizada como vazadouro de resíduos municipais, depositados diretamente no solo e cobertos com terra (figura 35$)^{36}$.

Figura 35- Resíduos depositados na área do Aterro de Bowers.

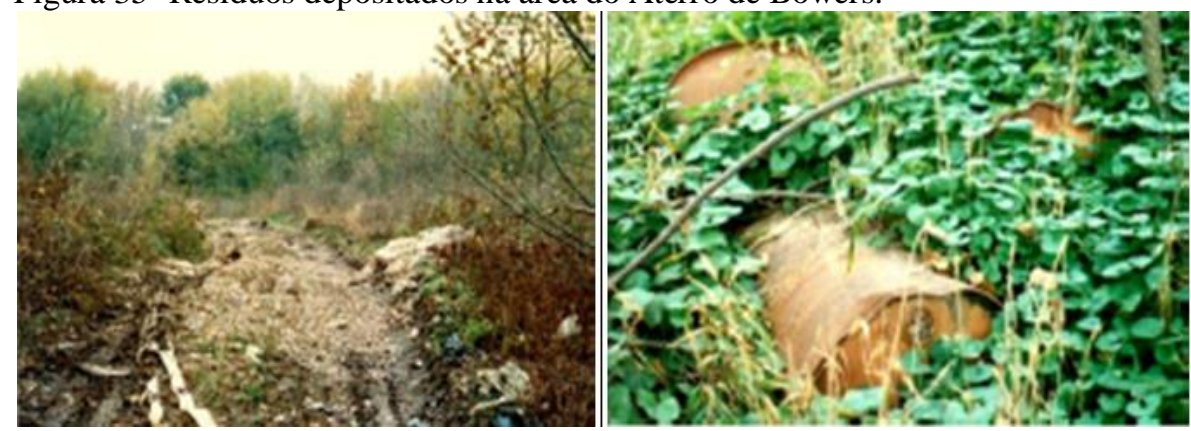

Extraído de: Usepa (apud MORINAGA, 2007, p. 107).

A partir de 1963, o local passou a receber resíduos químicos e industriais, e encerrado em 1968, sendo, em seguida abandonado. Em 1971, altas concentrações de substâncias químicas foram detectadas nas proximidades do rio Scioto (BARROS, 2011).

Em 1983, a área foi incluída na Lista de Prioridades Nacionais (NPL) da EPA para remediação, apontando como os potenciais responsáveis a Companhia E.I. DuPont de Nemours e as Indústrias PPG. As investigações realizadas detectaram a presença de metais, compostos orgânicos voláteis e semi-voláteis, pesticidas e PCB's nas águas subterrâneas (MORINAGA, 2007). As atividades de limpeza incluíram a remoção de resíduos contaminados, o fechamento e a revegetação da superfície do aterro.

O processo de remediação se iniciou em 1989, quando foram solicitadas intervenções para impedir a exposição à contaminação como: cobertura do aterro com argila, implantação de um sistema de drenagem superficial, monitoramento do biogás e das águas subterrâneas por trinta anos, após a cobertura do aterro.

Além disso, a EPA decidiu executar intervenções para proteger a nova cobertura do aterro contra inundações do rio Scioto, realizando uma construção de zona alagada (wetlands ${ }^{37}$ ) de 2,8 hectares entre o rio e o antigo aterro (MORINAGA, 2007).

\footnotetext{
${ }^{36}$ Disponível online: https://cumulis.epa.gov/supercpad/cursites/csitinfo.cfm?id=0504541. Acesso em 28 nov. 2019.

37 Zonas Alagadas- áreas úmidas, naturais ou construídas, com substrato saturado, pouco oxigenado, que favorece a presença de vegetação com funções para estabilizar o solo, os sedimentos e remover os nutrientes da água (SANCHES, 2014, p. 273).
} 
Com a reutilização da área foi possível inserir atividades de recreação e lazer para a população com pesca, canoagem, fotografias da vida selvagem e valorização das suas propriedades, ilustrado na figura 36.

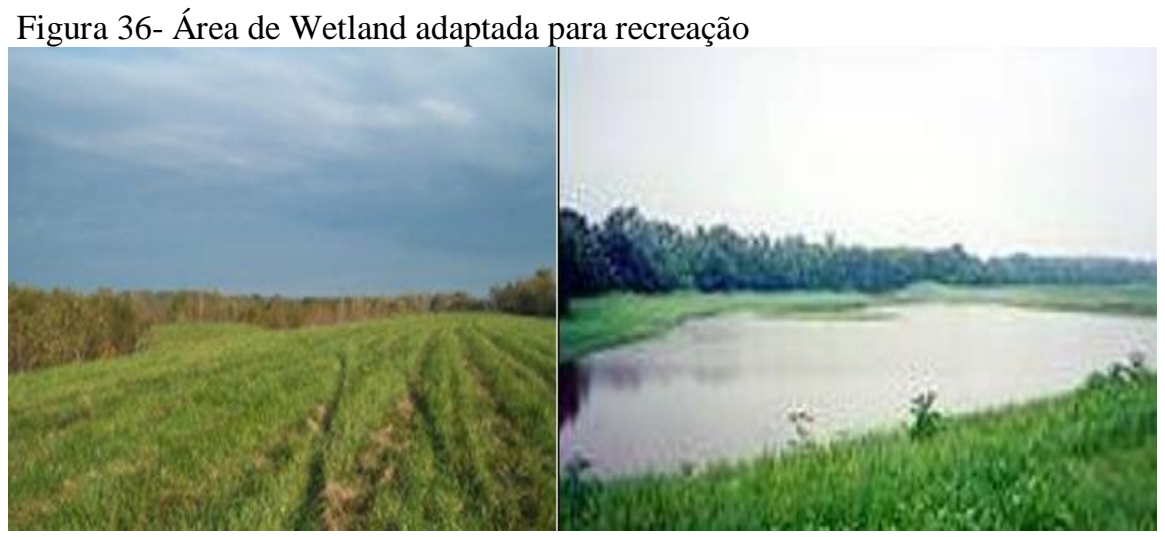

Extraído de: Usepa (apud MORINAGA, 2007, p. 107).

Além dos projetos e experiências apresentadas, BARROS (2011) aponta vários outros exemplos de requalificação de áreas de lixões e aterros em parques em outros países ${ }^{38}$ bemsucedidos, destacando que a maioria se encontra nos Estados Unidos ${ }^{39}$.

Como exemplo, pode ser citado o estudo realizado pelo Center for City Park Excellence, que em uma investigação superficial nas grandes cidades norte-americanas constatou que mais de 1.800 hectares de aterros já foram convertidos em parques com sucesso (HARNIK et al. 2006).

\subsection{EXPERIÊNCIAS PRÁTICAS NACIONAIS DE REQUALIFICAÇÃO EM PARQUES}

No cenário brasileiro, BARROS (2017) ressalta-se que a implantação de parques também tem sido indicada por muitos órgãos públicos como a melhor forma de requalificação para áreas contaminadas, com exemplos concentrados em São Paulo.

\footnotetext{
${ }^{38}$ Por exemplo: Parque La Coruña, na Espanha e os Parques ecológicos Shuen Wan e Sai Tso Wan, no Japão.

${ }^{39}$ Parque Arboretum, e Washington; Parque Millenium, em Boston, Massachusetts; Parque Mount Trashmore, na praia de Vírgina; Parque Natural Smith-Bybee, em Portland, no Oregom; Parque Mabel Davis, em Texas; Parque Tifft, em Buffalo; Parque Richard W. Dekorte, em Nova Jersey; Parque McMillian e Complexo Esportivo Tim Osmond, em Illinois e a Ilha Spectacle, caminho de entrada para outras 34 ilhas que constituem o Parque Nacional do Porto de Boston.
} 
LEITE (2005) destaca que essas áreas contaminadas em sua maioria estão situadas em áreas periféricas, onde vem ocorrendo intenso processo de expansão urbana com extrema carência de áreas verdes e de espaços públicos de lazer.

A maioria dos parques criados na cidade de São Paulo na década de 1990, foi em recuperação de áreas de mineração e de extração de areia desativadas, convertidos em áreas verdes. Exemplo disso são o Parque Ibirapuera, inaugurado em 1954; a Raia Olímpica da USP (1972); o Parque Ecológico do Tietê (1982); e o Parque Cidade de Toronto (1992) que hoje não apresentam relação com os usos originais e também pouco conhecimento se têm sobre o histórico desses locais (SANCHES, 2014).

No entanto, um exemplo bem-sucedido é o Parque Estadual Villa-Lobos inaugurado em 1994, no bairro de Alto de Pinheiros, zona oeste de São Paulo, que será apresentado mais adiante como estudo de caso. A seguir serão citados casos de projetos considerados bemsucedidos no contexto nacional.

\subsubsection{Aterro Carandiru x Parque da Juventude- São Paulo}

Em São Paulo, há o Parque da Juventude (figura 37), localizado no bairro do Carandiru, zona norte do município, inaugurado em 2003 e 2004.

Situa-se parcialmente sobre o antigo aterro Carandiru, onde foram enterradas cerca de 23 toneladas de resíduos por 72 dias no ano de 1977 (SVMA, 2014), e posteriormente transformado no complexo penitenciário Carandiru, demolido parcialmente em $2002^{40}$.

Figura 37- Parque da Juventude situado à Avenida Ataliba Leonel e Avenida Cruzeiro do Sul.

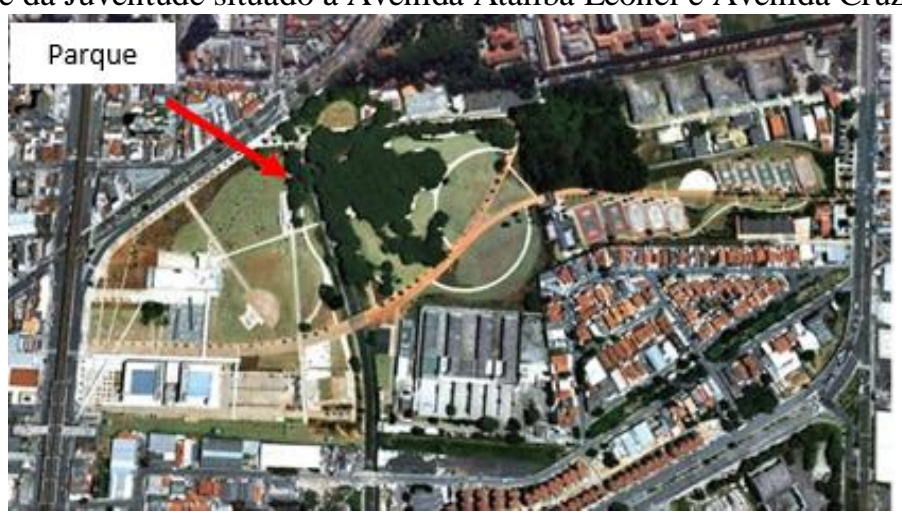

Extraído de: <http://aflalogasperini.com.br/blog/project/parque-da-juventude/>. Acesso em: 06 ago. 2020.

40 Disponível online: https://www.infraestruturameioambiente.sp.gov.br/parquedajuventude/historico/. Acesso em: 30 nov. 2019. 
O Parque possui $240 \mathrm{mil} \mathrm{m}^{2}$ e foi construído em parceria com a Secretaria Estadual de Esporte, Lazer e Turismo e pela empresa Aflalo/Gasperini Arquitetos, vencedora do concurso de projetos no ano de 1999.

A proposta incluiu a remodelação de dois conjuntos de edifícios existentes nas extremidades da gleba, ligados por um parque com momentos distintos, sendo um composto por quadras e equipamentos esportivos e outro voltado ao lazer passivo e à contemplação. Também o projeto buscou aproveitar a Estação Carandiru do metrô, vizinha do conjunto, por conferir uma condição ímpar para um equipamento urbano desse porte (figura 38$)^{41}$.

Figura 38- Parque da Juventude e a Estação Carandiru do Metrô.

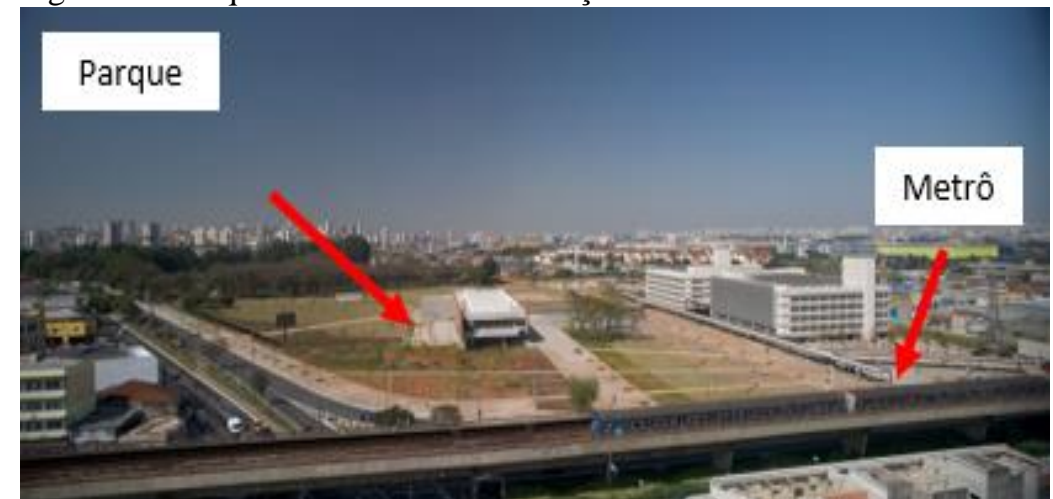

Adaptado de: 〈http://aflalogasperini.com.br/blog/project/parque-da-juventude/>. Acesso em: 06 ago. 2020.

O parque está dividido em três grandes setores: área esportiva (quadras poliesportivas), recreativo (trilhas, caminhos ajardinados) e cultural (Biblioteca de São Paulo e ETEC), respectivamente, sendo a primeira etapa concluída em 2003, ano de inauguração do parque, como ilustrado na figura 39 (SANCHES, 2011).

No final de 2008, o Parque da Juventude foi considerado o segundo melhor parque de São Paulo em pesquisa realizada pelo Sindicato Nacional das Empresas de Arquitetura e Engenharia, recebendo uma média de 110 mil usuários por mês. Em 2012, o Parque da Juventude passou a ser administrado pela Secretaria de Estado do Meio Ambiente, por intermédio da Coordenadoria de Parques Urbanos - CPU.

O Parque da Juventude preserva algumas ruínas das antigas instalações da penitenciária como forma de preservação histórica do local (SANCHES, 2014).

41 Parque da Juventude- Disponível Online:<http://aflalogasperini.com.br/blog/project/parque-da-juventude/>. Acesso em: 06 ago. 2020. 
Figura 39- Áreas do Parque da Juventude em São Paulo.

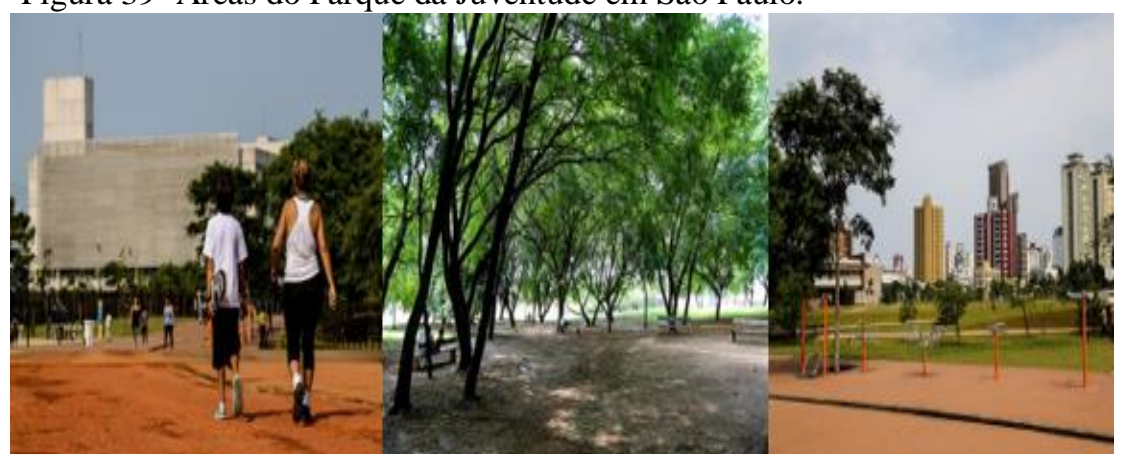

Extraído de: <https://www.infraestruturameioambiente.sp.gov.br/parquedajuventude/fotos/>. Acesso em: 30 nov. 2019.

\subsubsection{Aterro Sapopemba x Parque Aterro Sapopemba- São Paulo}

Em 2013, foi inaugurado o Parque Aterro Sapopemba, no bairro de São Mateus, extremo leste do município de São Paulo, implantado sobre o Aterro Controlado Sapopemba.

$\mathrm{Na}$ área foi desenvolvido um aterro de encosta que recebeu resíduos domiciliares, instalado e operado pelo município de São Paulo, de 1979 a 1984 quando foi encerrado em ação popular movida por moradores das adjacências. Estima-se que durante o período de atividade operacional foram dispostos 3,1 milhões de toneladas de resíduos domésticos.

O terreno possui terreno de $304.477 \mathrm{~m}^{2}$ e seu entorno é bastante marcado por recente expansão urbana caracterizada pela presença de conjuntos habitacionais e casas construídas, ilustrado na figura 40 (SVMA, 2009).

Figura 40- Aterro Controlado Sapopemba.

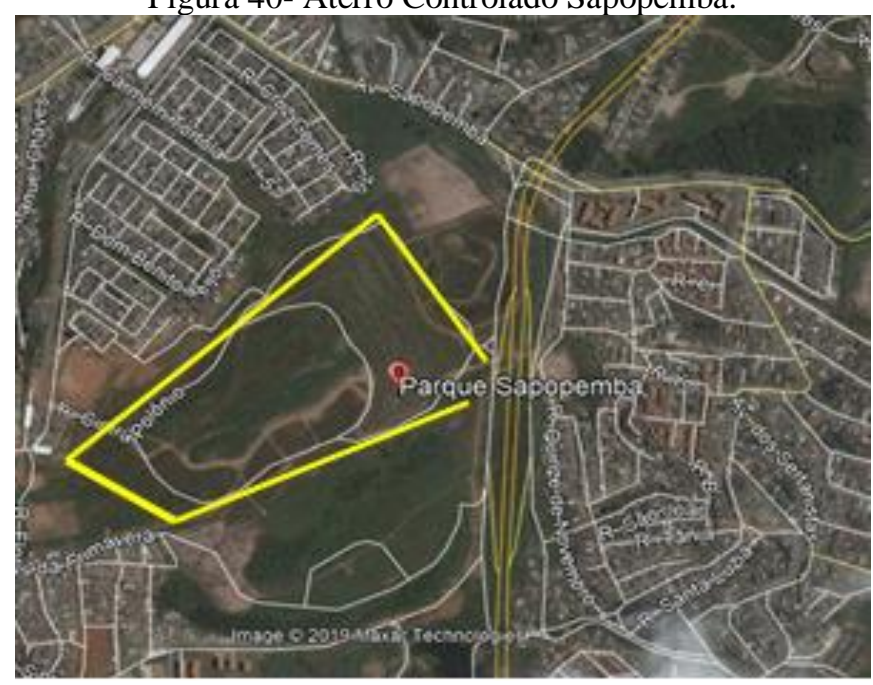

Extraído de: GOOGLE EARTH, 2004. 
Os estudos ambientais começaram a ser realizados no ano de 2004, no qual constatou a contaminação da água subterrânea por metais (alumínio, bário, chumbo, ferro e manganês), ficando restrito a captação e o uso da água subterrânea local para qualquer fim.

Também foi constatada a contaminação do solo por arsênio e vanádio em profundidades nas quais não são prováveis as vias de exposição (dérmica e inalação), evidenciando desta forma, a não existência de riscos à saúde da população e futuros usuários do parque (SVMA, 2009).

O problema da contaminação foi solucionado com o acréscimo de uma camada de solo limpo de $50 \mathrm{~cm}$ de espessura em toda extensão do terreno, onde houve a disposição de resíduos, evitando-se apenas o recobrimento nos drenos e chaminés existentes no aterro, para liberação do metano presente na massa de resíduos (SVMA, 2009).

Atualmente existem vários núcleos habitacionais de interesse social no entorno do parque que foi construído 2013. A área passou a ser um parque público municipal, denominado de Parque Aterro Sapopemba.

No parque não há edificações e áreas confinadas. É constituído de áreas esportivas abertas como quadras, dois campos de futebol, caminhos, sede, praça central, áreas de estar e equipamentos de ginástica, como ilustra a figura 41. Dispõe de estacionamento gratuito, rede wifi, acessibilidade em banheiros e áreas de circulação ${ }^{42}$.

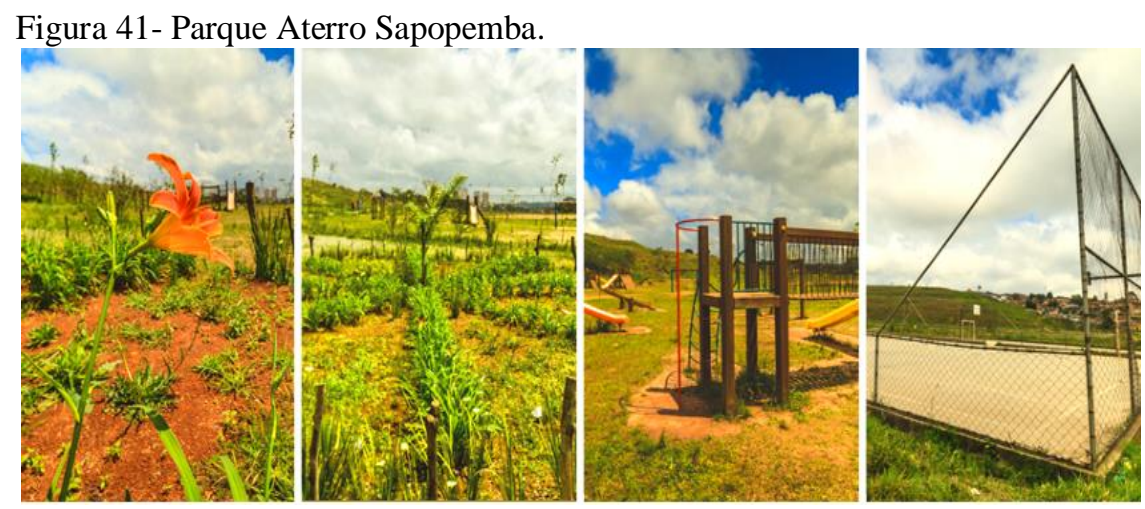

Extraído de: https://www.prefeitura.sp.gov.br. Acesso em: 30 nov. 2019.

42 Disponível online: https://www.prefeitura.sp.gov.br/cidade/secretarias/meio_ambiente/parques. Acesso em: 30 nov. 2019. 


\subsubsection{Lixão Sambaiatuba x Parque Ambiental Sambaiatuba- São Vicente}

Em 2002, no município de São Vicente, na divisa com Santos ao longo do rio Bugre, foi inaugurado o Parque Ambiental Sambaiatuba, implantado sobre o lixão do Sambaiatuba, figura 42 .

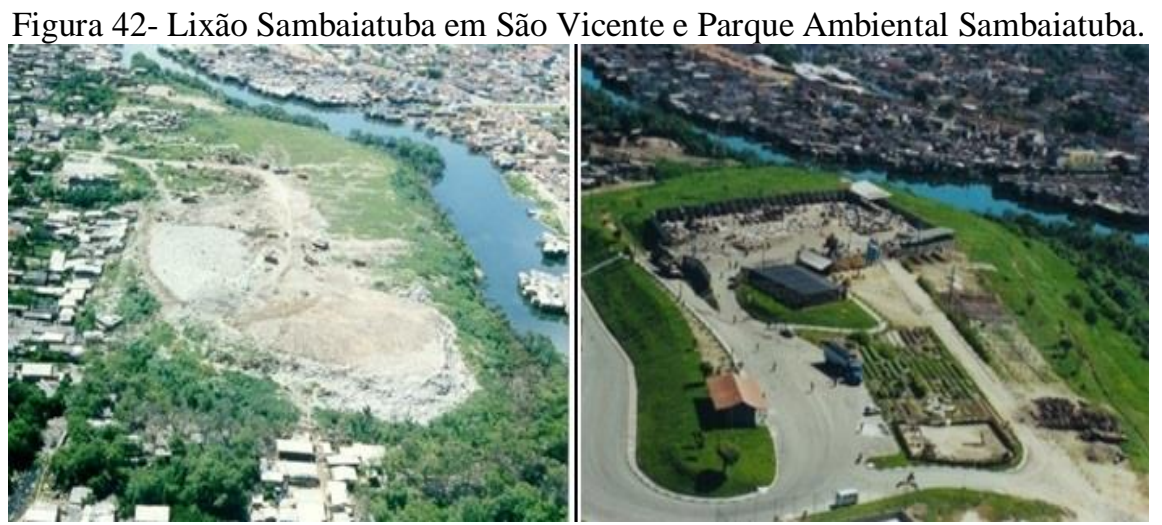

Extraído de: http://www.codesavi.com.br/proj_view.php?id=17. Acesso em 05. Dez. 2019.

O lixão, instalado sobre manguezais, funcionou por mais de trinta anos, tendo recebido resíduos de diferentes fontes, a partir de 1969 numa área de aproximadamente $47.000 \mathrm{~m}^{2}$ e 17 metros de altura. O processo de desativação do lixão ocorreu por meio Termo de Ajustamento de Conduta (TAC), firmado em 1999 e complementado em 2000, entre a CETESB, a Secretaria de Estado do Meio Ambiente e a Prefeitura Municipal de São Vicente (MORINAGA, 2007).

Para garantir as medidas de segurança e o plano de recuperação da área, algumas intervenções foram necessárias principalmente quanto à estabilidade do maciço de resíduos e seu recobrimento, evitando deslizamentos (figura 43) (MORINAGA, 2007).

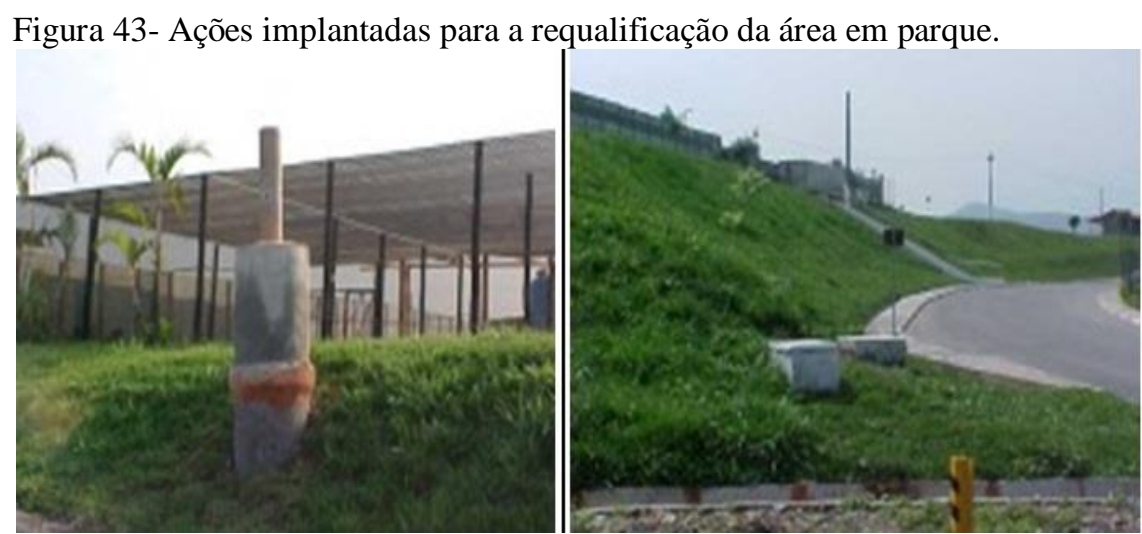

Extraído de: http://www.codesavi.com.br/proj_view.php?id=17. Acesso em: 05 dez. 2019. 
Para cobertura dos resíduos, em função da escassez de solo argiloso no local foi utilizado material das obras da cidade e uma parcela proveniente da praia do Itararé. É importante destacar que esses materiais não são recomendados para tal finalidade, em função de serem muito permeáveis e facilitarem a infiltração das águas pluviais e a emissão dos gases para a atmosfera ${ }^{43}$ (MORINAGA, 2007).

Para dar vazão aos gases produzidos foram instalados drenos com tubos de concreto de $60 \mathrm{~cm}$ de diâmetro e com espaçamento de aproximadamente 40 metros. Durante as sondagens de investigação do solo foram instalados 17 poços de monitoramento ao longo da margem do rio, no qual é realizado o monitoramento da qualidade das águas, das edificações, estabilidade dos taludes e drenagem superficial ${ }^{44}$.

O parque possui áreas de lazer e esportes com jardins, playgrounds e quadras poliesportivas. Também tem viveiros para a produção de mudas para plantio no parque e nas praças da cidade; um projeto de reposição das espécies de mangue; uma escola de educação ambiental para atendimento da comunidade; horta comunitária e compostagem; projeto socioambiental de reciclagem voltado aos catadores do antigo lixão, que resultou em uma cooperativa, figura 44.

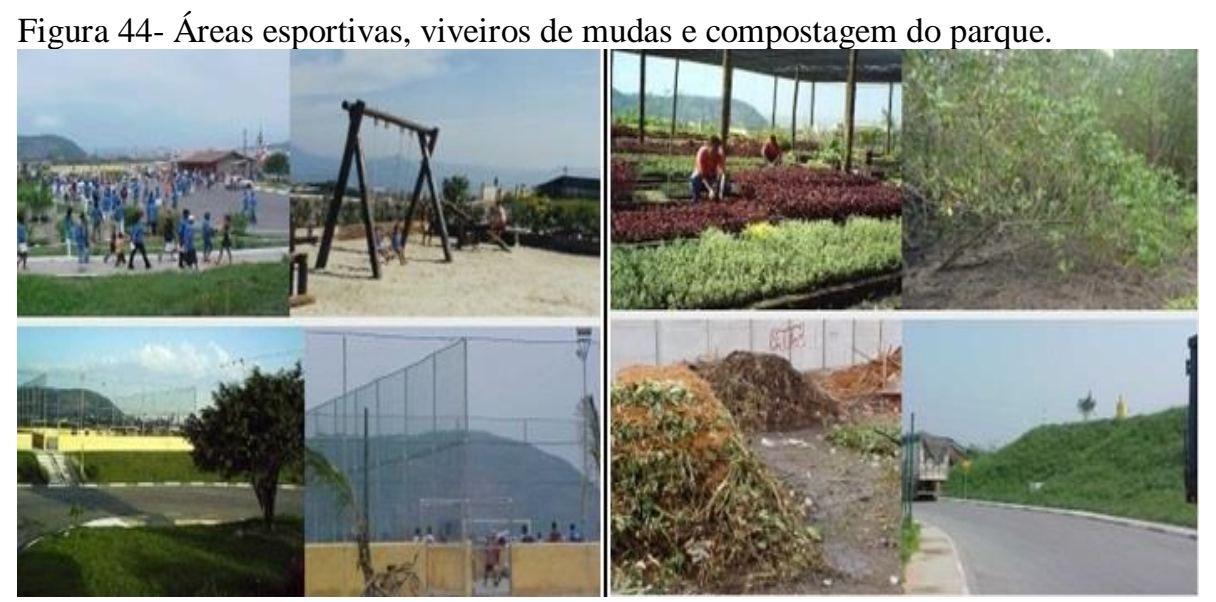

Extraído de: http://www.codesavi.com.br/proj_view.php?id=17. Acesso em: 05 dez. 2019.

As intervenções apresentadas demonstram diferentes maneiras de ações para recuperar e revitalizar áreas contaminadas em parques, trazendo a sua reincorporação ao tecido urbano

\footnotetext{
${ }^{43}$ Disponível online: http://www.codesavi.com.br/proj_view.php?id=17. Acesso em: 05 dez.2019.

${ }^{44}$ Idem ao 43.
} 
novamente. Além disso, a diversidade de tais áreas resulta em um leque de opções e possibilidades que podem ser trabalhadas em conjunto como destacado por SANCHES (2014).

SOUSA (2004) destaca que a possibilidade de criar áreas verdes com diferentes tamanhos e tipos é um instrumento para o desenvolvimento de estratégicas de melhorias da condição do ambiente urbano e da qualidade de vida da população.

\subsection{BENEFÍCIOS DOS PARQUES PARA A SAÚDE PÚBLICA E O ESPAÇO URBANO}

Segundo a definição estabelecida no Programa Municipal de Arborização Urbana pela Lei Municipal No 14.186/2006, os parques públicos são considerados como:

I - as áreas verdes públicas, compostas pelo rol de logradouros públicos destinados ao lazer e recreação ou que proporcionem ocasiões de encontro e convívio direto com espaços não construídos ou arborizados (grifo nosso);

II - as áreas verdes privadas, compostas por remanescentes vegetais significativos incorporados aos interstícios da malha urbana, podendo ter sua utilização normatizada por legislação específica de forma a garantir a sua conservação;

III - a arborização de ruas e vias públicas (SÃO PAULO (cidade), 2006).

Em outras palavras, referem-se às áreas verdes públicas englobando os parques lineares, as praças e os jardins públicos, exceto áreas verdes que não exerçam funções ecológicas ou que possuam infraestrutura que a população não possa usufruir, como é caso dos canteiros viários e rotatórias (SANCHES, 2014).

No mundo todo, os parques urbanos são considerados como locais de integração e exercício da cidadania com todas as classes sociais e idades, além de ideais para o desenvolvimento de programas permanentes e campanhas de educação ambiental. Contudo, uma vez inseridos nas áreas urbanas, promovem vários benefícios voltados ao atendimento imediato da população quanto à conservação da biodiversidade (BONONI, 2014).

$\mathrm{Na}$ literatura, muitos estudos existentes confirmam diversos fatos dos benefícios e da importância dos parques no âmbito socioeconômico, de saúde pública como no ambiental.

SHINZATO (2009) destaca que pequenas áreas verdes distribuídas de forma homogênea, principalmente em ambientes densamente urbanizados, podem trazer resultados 
positivos para a cidade como microclima e o conforto ambiental. Já BASCH (2016) aponta que a existência de áreas verdes urbanas possibilita a melhora da qualidade do ar, a moderação do microclima, a permeabilização do solo, evitando principalmente inundações em zonas críticas e que o aumento com o contato com a natureza, acima de tudo, contribui com uma melhoria da saúde física, social e psicológica dos indivíduos e comunidades.

Entre outros serviços ambientais e ecológicos que os parques prestam à cidade, estão também a estabilização de encostas, a recarga de aquífero, a diminuição da poluição do ar e das águas, recreação e cultural (BONONI, 2014; SANCHES, 2014).

O estudo de Herbs 2001 (apud SANCHES, 2014), aponta que a população urbana necessita de contato com a natureza, a qual devem estar a uma distância de cinco a dez minutos de casa, andando a pé. Chaddad ${ }^{46} 2000$ (apud SANCHES, 2014), demonstra uma correlação entre a quantidade de áreas vegetadas de uma cidade e a qualidade de vida oferecida a seus habitantes, como a promoção de bem-estar e de inclusão social.

Já no estudo de BARTON e PRETTY (2010), ficou evidenciado que contato com a natureza leva a resultados positivos para a saúde em curto e longo prazo. O estudo demonstrou que apenas cinco minutos de caminhada em áreas verdes, já é suficiente para trazer melhorias na saúde mental das pessoas, como o humor e a autoestima. Além disso, tais evidências sugerem que as pessoas sedentárias e/ou com problemas de natureza psíquica, teriam benefícios na saúde mental se comprometendo a exercícios de curta duração em áreas verdes acessíveis.

Assim, os parques são locais que promovem a sensação de bem-estar dos usuários, de práticas esportivas, de maior socialização e estímulo à identidade da comunidade com o local, exercendo papel de motivador e de inclusão social.

Por outro lado, a criação de novos parques valoriza economicamente os imóveis próximos a elas, aumentando o valor de venda e atraindo novos investimentos que podem estimular novos negócios voltados ao lazer e atividades afins, como comércio de alimentos, aluguel de bicicletas, venda de equipamentos de lazer e esporte, promovendo o aumento de empregos locais e arrecadação de impostos (SANCHES, 2014).

\footnotetext{
45 HERBST, H. The importance of Wasteland as urban wildlife áreas: with particular reference to the cities Leipzing and Birmingham. Tese de Doutorado. Leipzing: Faculdade de Física e Geografia- Universidade de Lepzing, 2001.

${ }^{46}$ CHADDAD, J. Evolução urbana na arquitetura e no paisagismo. Em DEMÉTRIO, U. A. et al. Composição paisagística em parques e jardins. Piracicaba: Fealq, 2000.
} 
SANCHES (2017) aponta que, perante o contexto dos conflitos sociais e a marginalização presente nas grandes cidades como São Paulo, a transformação de áreas contaminadas em áreas verdes mostra uma oportunidade na promoção do aumento da qualidade de vida da população, diminuindo a criminalidade e as tensões sociais, especialmente em zonas periféricas em expansão.

Um exemplo a ser citado é o Went Field, um parque de uso intenso em Bridgeport Connecticut (EUA) que passou por um re-desenvolvimento e expansão em uma área contaminada. Posteriormente foi recuperada e remediada e com as ações do programa do departamento policial local e o apoio da população, o tráfico de drogas foi amplamente erradicado (SANCHES, 2011).

Neste contexto, destaca-se a urgência em promover melhorias na qualidade de vida da população da região de São Miguel Paulista, no extremo leste do município de São Paulo com a retomada das obras de implantação do Parque Municipal Jardim Primavera.

Com 145.443 habitantes, o distrito de Vila Jacuí, região em que o parque está inserido, conta com um crescimento urbano desordenado que se deu através da ocupação nas áreas de várzea do Rio Tietê e sobre os córregos que sofrem com inundações em épocas de chuva e esgotamento sanitário (SMDU, 2016; SMDU 2016a). Existem loteamentos irregulares em condições inadequadas com domicílios contendo mais de três moradores por dormitório, caracterizando-se um contexto de vulnerabilidade social em aglomerados subnormais. De maneira geral, a população está em situação de alta vulnerabilidade social e a demanda por serviços públicos está associada à assistência social (SMDU, 2016; SMDU, 2016a).

Em relação ao meio ambiente, São Miguel Paulista apresenta cobertura vegetal $\left(8,9 \mathrm{~m}^{2} /\right.$ habitante) e áreas verdes públicas $\left(2,9 \mathrm{~m}^{2}\right)$, bem abaixo da média do munícipio que é de $\left(54 \mathrm{~m}^{2} /\right.$ habitante) e $\left(14,1 \mathrm{~m}^{2} /\right.$ habitante $)$, caracterizando a baixa presença de cobertura vegetal em áreas de ocupação urbana (BARROS, 2011; SMDU, 2016).

Perante a esse cenário, nota-se que com a implantação do Parque Municipal Jardim Primavera é possível amenizar os impactos negativos decorrente do acelerado processo de urbanização sem planejamento ocorrido na região, que por sua vez promovem o aumento da poluição atmosférica e dos rios. Além disso, fica evidente a necessidade por parte do poder municipal uma percepção ambiental, ao que tange o entendimento e importância de como se dá a relação do ser humano com o ambiente.

Segundo (SANTOS et al. 2019) relatam que por meio dessa compreensão pode-se formular políticas de conservação, assim como tomada de decisão ter uma estratégia de gestão 
de áreas verdes públicas, mais eficiente, voltada aos desejos e anseios da população que frequenta o local. Além disso, destaca-se que a requalificação de área contaminada protege a saúde pública e o meio ambiente, além de estimular o mercado econômico do entorno e revigorar as comunidades. 


\section{RESULTADOS}

O município de São Paulo possui 11.811.516 habitantes residindo em seu território de $1.521 \mathrm{~km}^{2}$ e densidade demográfica de 7.765 hab. $/ \mathrm{km}^{2}$, sendo o principal da região metropolitana, concentra todas as atividades de interesses econômico, cultural e social da cidade (FUNDAÇÃO SEADE, 2019). É constituído por 96 distritos que são subdivididos em 32 subprefeituras regionais.

A seguir serão apresentados dois casos de parques desenvolvidos em áreas contaminadas localizados no município de São Paulo. Nos dois casos a contaminação foi oriunda da disposição irregular de resíduos diretamente no solo, os quais foram submetidos ao gerenciamento de áreas contaminadas estabelecido pela CETESB para o processo de reutilização e reabilitação, na forma de parque público.

\subsection{ESTUDO DE CASO 1: PARQUE MUNICIPAL JARDIM PRIMAVERA}

\subsubsection{Localização da Área de Estudo}

O Parque Municipal Jardim Primavera possui uma área de $122.000 \mathrm{~m}^{2}$ e apresenta as coordenadas geográficas UTM: 350.936 X7.400.017. Localiza-se na confluência das avenidas Antônio Louzada Antunes, Mimo de Vênus e Rua Arareua s/n, junto sistema viário JacuPêssego, na zona leste do município de São Paulo, no distrito de Vila Jacuí, como ilustra a figura 45 (RAMIRES; VITOR, 2010; SVMA, 2016a).

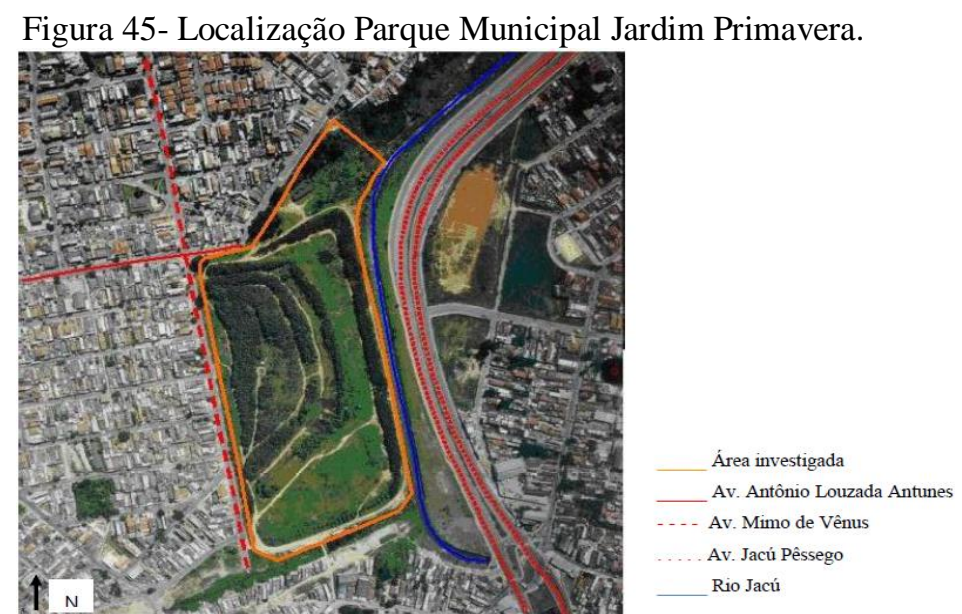

Extraído de: RAMIRES; VITOR, 2010. 
Este parque está inserido na Bacia do Alto Tietê e o corpo hídrico mais próximo ao terreno é o córrego Jacu localizado entre o imóvel e a Avenida Jacu Pêssego.

De acordo com a Lei $\mathrm{n}^{\circ} 16.402$ de 22 de março de 2016, a área é classificada como Zona Especial de Preservação Ambiental (ZEPAM) e pertencente ao município. Esta área é destinada à preservação e à proteção do patrimônio ambiental, visando a conservação da biodiversidade, o controle de processos erosivos e de inundação, produção de água e regulação microclimática (SÃO PAULO (cidade), 2016).

Já no entorno do parque, a área está classificada como zona mista (ZM) e zona de centralidade polar (ZCP).

A ZM está destinada a promover a implantação de usos residenciais e não residenciais, inclusive no mesmo lote ou edificação, predominando o uso residencial com densidade construtiva e demográfica em zonas mistas de baixa, média e alta densidades (SÃO PAULO (município), 2014). Já ZCP são porções do território voltadas à promoção de atividades típicas de áreas centrais ou de bairros, destinadas principalmente a usos não residenciais, como os comércios e serviços existentes (SÃO PAULO (cidade), 2016).

De acordo com o Plano Diretor do município, a área está situada na Macrozona de Estruturação e Qualificação Urbana, ou seja, integralmente na zona urbana. Nessa área é constituída grande diversidade de padrões de uso e ocupação do solo, desigualdade socioespacial, padrões diferenciados de urbanização e é a área do município mais propícia para abrigar os usos das atividades urbanas (SÃO PAULO (cidade), 2014).

\subsubsection{Histórico: Uso e Ocupação do Solo}

A área ocupada pelo aterro até a década de 1950 se apresentava com uma pequena movimentação de terra, mas por volta de 1968 iniciou-se a exploração de areia por uma empresa privada, atividade comum e executada em várias regiões da cidade.

Essa atividade acabou resultando na formação de duas cavas, uma maior e outra menor praticamente ocupando todo o imóvel, representando um grande dano ambiental figura 46. Além disso, em função da interceptação do lençol freático, nessas cavas formaram-se lagoas (GEOINTEGRA, 2013; SVMA, 2016a). 
Figura 46- Formação das cavas em 1968 e 1977.
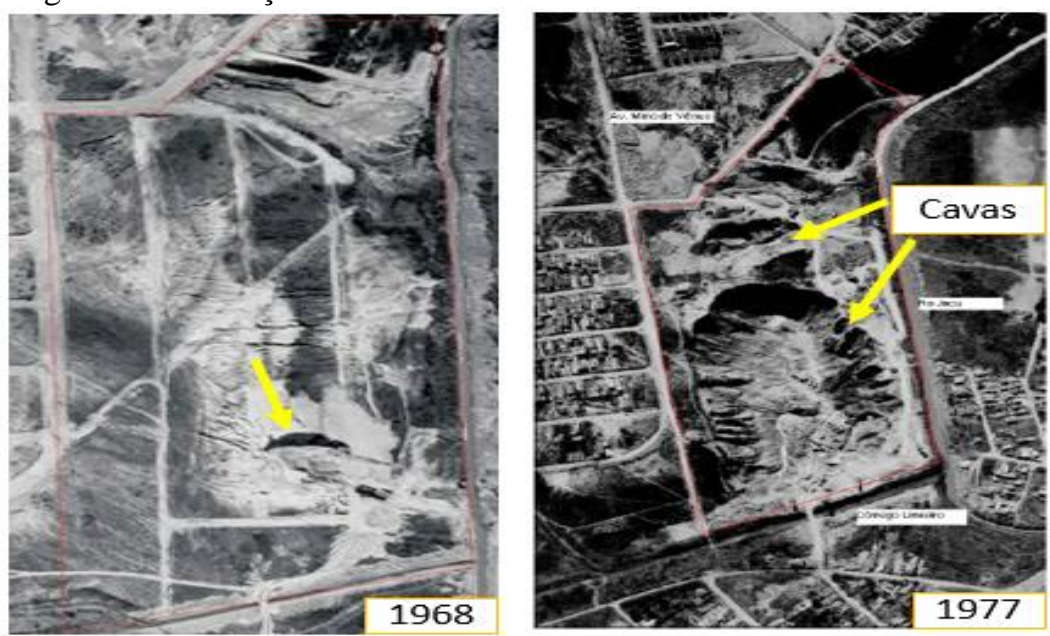

Extraído de: SVMA, 2016a.

As cavas de mineração tinham em média uma profundidade de 25 metros em relação ao nível natural do terreno, atingindo até 40 metros. A cava maior tinha uma área de $60.784 \mathrm{~m}^{2}$ e a menor de $11.750 \mathrm{~m}^{2}$, e em função dessa profundidade e das chuvas no local, a área passou apresentar riscos de afogamentos para a população residente no entorno (LIMPURB, 1983; WEBER, 2007).

Diante dessa situação, por volta de 1979, a prefeitura de São Paulo foi pressionada pela população local para o aterramento das cavas que passou a receber RSU no local (CETESB, 1998; BARROS, 2011; SVMA, 2016a).

Em resposta imediata à população, a cava menor foi aterrada com solo proveniente do nivelamento do terreno, e a cava maior continuou a receber resíduos de construção civil (entulho), porém não existindo nenhum controle para sua disposição. Entretanto, é certo que o local também recebeu outros tipos de resíduos e esse processo foi realizado de 1979 a 1988 (GEOINTEGRA, 2013; SVMA, 2016a).

A partir de então, os resíduos passaram a ser dispostos de forma aleatória sobre a cava maior de mineração em precárias condições de operações e sem medidas técnicas para proteção do solo e das águas subterrâneas, transformando-se em um lixão (RAMIRES; VITOR, 2010).

Em meados de 1981, com a reclamação da população novamente ao poder público (Administração Regional de São Miguel Paulista, atualmente a Subprefeitura) por causa das condições precárias da área e mais necessidade de um local para a disposição do lixo da zona leste, a Prefeitura Municipal de São Paulo se propôs a construir um aterro sanitário (CETESB, 1998). 
Deste modo, foi elaborado o projeto de aterro sanitário do Jacuí, em outubro de 1983, o qual teve parecer técnico favorável da Cetesb (PT 01/1984/DRD) (LIMPURB, 1983; CETESB, 1984; CETESB, 1998).

$\mathrm{O}$ aterro sanitário proposto foi projetado de maneira tal que seria constituído por dois aterros menores, com objetivo de aproveitar a conformação das duas cavas, uma com superfície de $60.74 \mathrm{~m}^{2}$ e a outra $11.750 \mathrm{~m}^{2}$, ilustrado na figura 47 (CETESB, 1984).

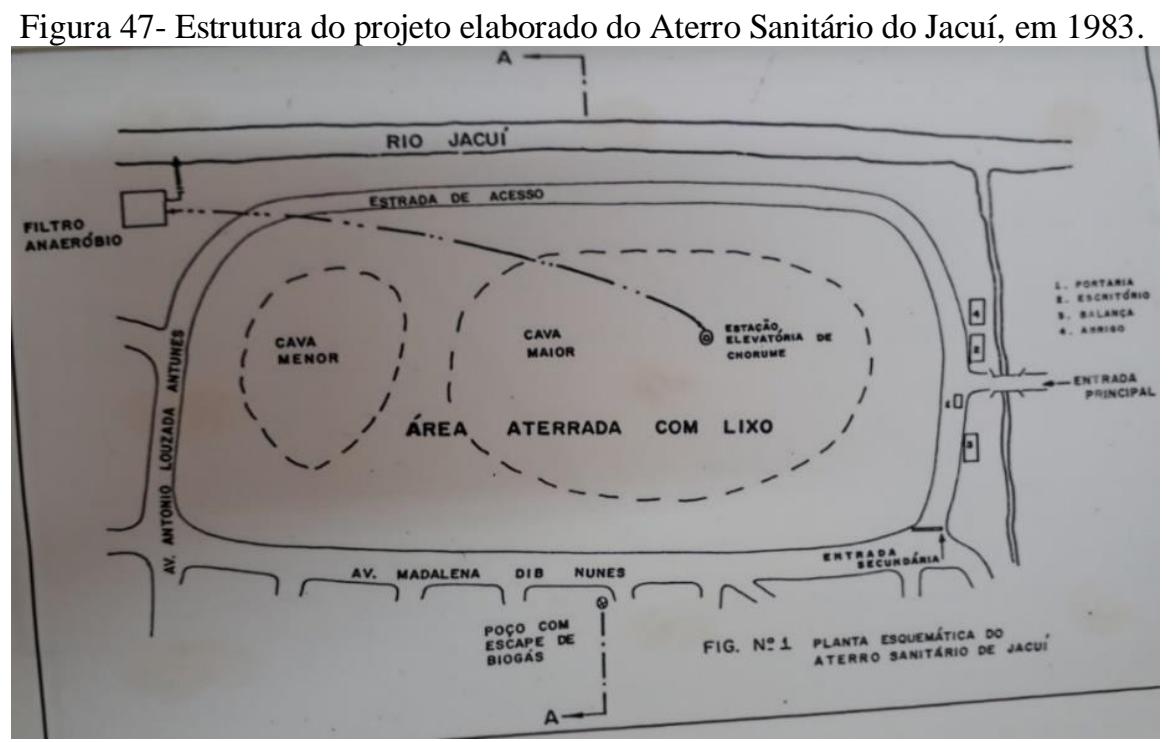

Extraído de: CETESB, 1984.

$\mathrm{O}$ aterro da cava maior, a qual encontrava-se preenchida parcialmente com resíduos (até a cota de 85 metros), seria constituído de 8 camadas, sendo 4 camadas e a primeira de regularização, com altura variando de 1,0 a 5,0 metros e as demais com 5,0 metros para sustentação dos taludes de escavação.

Para a cava menor teria um preenchimento de material inerte até a cota de 87 metros e o restante seria preenchido por resíduos domésticos, com procedimento idêntico à cava maior. Essa projeção do aterro apresentaria vida útil de aproximadamente 2 anos (CETESB, 1984; RAMIRES; VITOR, 2010).

Ainda de acordo com o projeto, o aterro seria provido de: sistema de drenagem das águas nascentes junto à encosta do talude; sistema de drenagem para coletar os líquidos percolados e encaminhá-los através de recalque, ao sistema de tratamento; sistema de drenagem de gases; sistema de drenagem superficial para captação e afastamento das águas precipitadas; sistema de recalque de líquidos percolados; sistema de recalque de líquidos 
percolados para o tratamento e sistema de tratamento de líquidos percolados, através de filtros anaeróbios (CETESB, 1984).

Mas, em função da urgência de um local para a disposição dos resíduos, instalaram-se drenos de gases na área das cavas, as quais coletavam e queimavam os gases gerados pelos 2,5 milhões de resíduos depositados tendo sua operação finalizada em 1988, representado nas figuras 48 e 49 (ENTERPA,1996; BARROS, 2011; SVMA, 2016a).

Figura 48- Aterro Controlado com a instalação dos drenos.

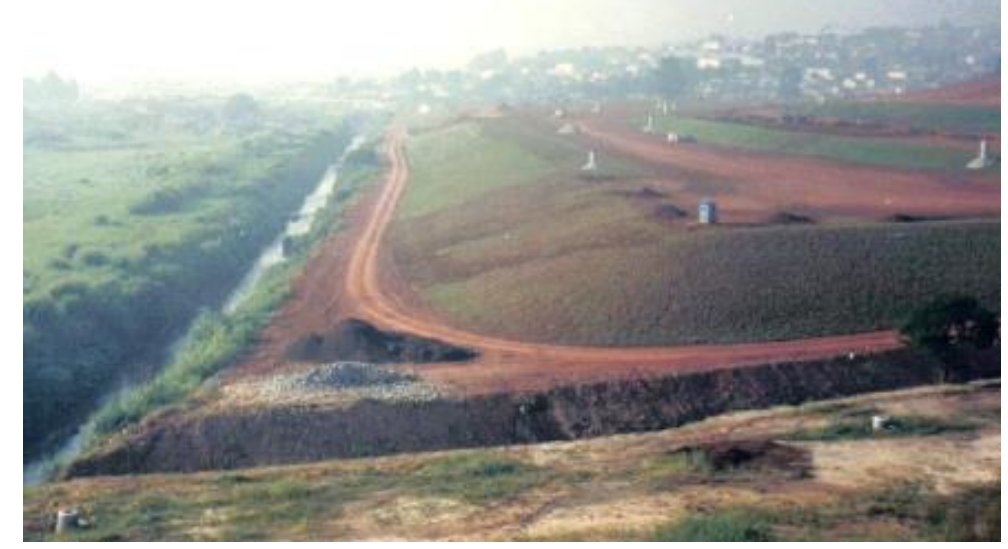

Extraído de: RAMIRES; VITOR, 2010.

Figura 49- Aterramento das cavas (1988) e cobertura com eucaliptos em 1993.

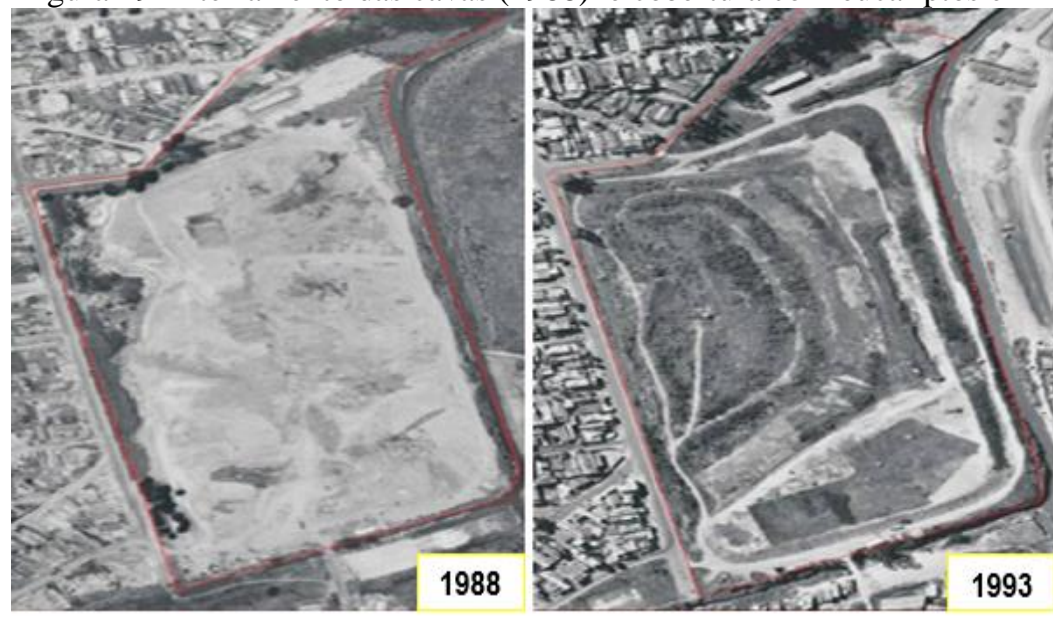

Extraído de: SVMA, 2016a.

Ainda no ano de 1988, próximo do término de vida útil do aterro, a Cetesb (Agência Ambiental do Tatuapé) foi acionada pelos moradores da vizinhança para verificar a migração de gases do aterro para dentro de algumas residências do entorno. 
Essa migração, ocasionou um acidente de explosão em uma residência situado na Rua Grinalda de Noiva, 253 (figura 50) com ferimento em duas pessoas, em função da presença de biogás com forte intensidade num poço próximo (CETESB,1998).

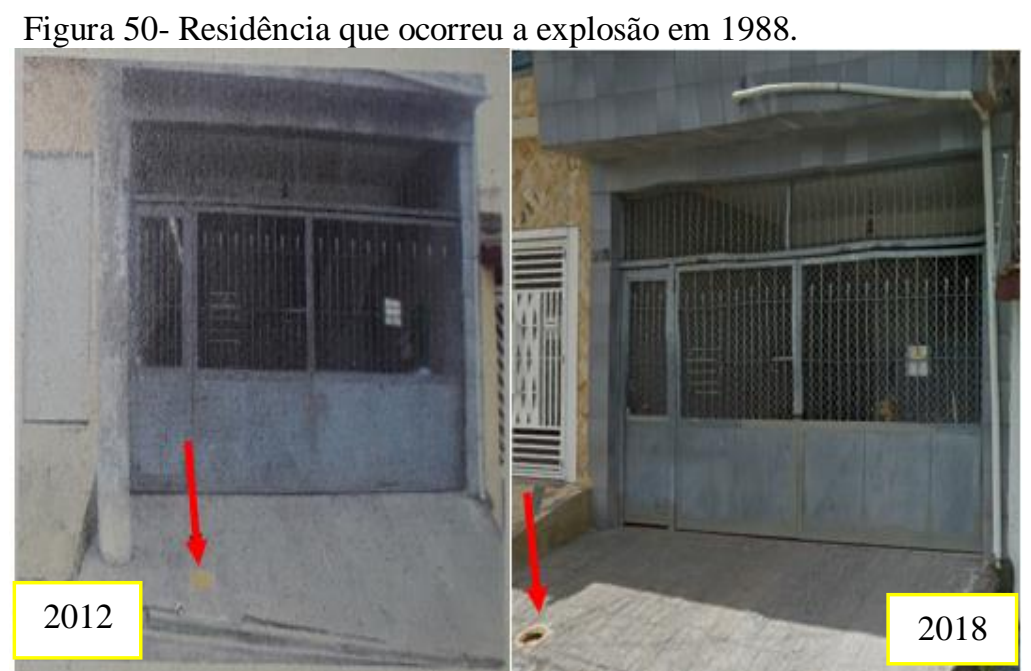

Legenda: Poço de monitoramento instalado na calçada, sinalizado pela seta vermelha. Extraído de: (SVMA, 2012; GOOGLE EARTH, 2018).

A partir daí, entre o período de 1988 e 1994, em sucessivas inspeções técnicas da Cetesb, constatou-se por meio de medidas com explosímetro a presença de biogás em vários locais das residências vizinhas, tais como no ponto de saída do conduíte de instalação de uma campainha, na calçada, num poço de água, em ralos de drenagem de águas pluviais e em rachaduras existentes no solo e na pavimentação das ruas (CETESB, 1998; BARROS, 2011).

Em decorrência do fato, a CETESB determinou o fechamento de todos os poços de abastecimento de água na região, permanecendo apenas o situado da Rua Grinalda da Noiva para monitoramento e solicitou a construção de drenos mais profundos na área.

Em 1995, durante a construção do trecho do sistema viário Jacu-Pêssego, localizado na avenida São Miguel distante cerca de 500 metros do aterro, foi detectada a liberação de gás metano em três pontos de sondagens de reconhecimento do solo. Contudo, como havia suspeita de que os gases poderiam ter migrado do aterro Jacuí, em setembro de 1996, foram executadas quatro sondagens no interior do aterro, sem, todavia, ter sido detectada a presença dos mesmos (CETESB, 1998; RAMIRES; VITOR, 2010; BARROS, 2011).

Daí então, a Cetesb (Agência Ambiental do Tatuapé) passou a acompanhar de maneira contínua as inspeções realizadas na área com base nas reclamações da população, assim como 
o processo da fase de encerramento do aterro, se deu principalmente por causa da segurança (CETEBS,1998).

Em paralelo, em 1990, o município elaborou o projeto piloto do parque para a implantação denominado de Primavera. O projeto foi elaborado por meio do Departamento de Parques e Áreas Verdes (DEPAVE) ligado, à época, à Secretaria Municipal de Serviços e Obras (SSO), embora não contemplasse os estudos prévios para avaliação da contaminação do solo e das águas subterrâneas (RAMIRES; VITOR, 2010).

Contudo, o projeto já trazia uma preocupação quanto aos possíveis riscos à saúde humana que a área apresentava, pois previa poucas edificações a serem construídas fora da área aterrada com resíduos e quadras esportivas com gramados, evitando o contato direto com solo e a confinação dos gases.

Além disso, a arborização deveria considerar o plantio de espécies de raízes superficiais na área aterrada, e raízes mais profundas em locais que mantinham o solo natural (RAMIRES; VITOR, 2010).

Porém, mesmo sem estudos prévios deu-se início à execução do projeto, que foi paralisado em seguida, pelo motivo da detecção de gases durante a implantação, inviabilizando a utilização do terreno para finalidade pretendida.

Dentre os problemas foram identificados: odor forte de gás, borbulhas provocadas pelas emanações, borbulhas nas poças d'água inclusive externas ao maciço de aterro e a dificuldade para a plantação dos gramados. Esses problemas fizeram com que ocorresse a paralisação das obras, em 1991, com sugestão de aguardar a estabilização do terreno e eliminação dos gases (BARROS, 2011).

No mesmo ano, o DEPAVE deu início a um estudo pioneiro que contemplou a identificação de espécies vegetais que melhor se adaptariam às condições adversas. O estudo delimitou três áreas testes com diferentes tipos de vegetação: bosque de essências nativas e exóticas, gramíneas e leguminosas e regeneração espontânea (MORINAGA, 2007; BARROS, 2011). Foi previsto um prazo de cinco anos para adaptabilidade das espécies ao substrato, no entanto, o estudo não teve prosseguimento e foi paralisado no ano seguinte em 1992, com a consequente perda das espécies (MORINAGA, 2007).

Entretanto, em 1995 foram plantados 5.000 eucaliptos (figura 51) na área por meio de uma ação da empresa Via Verde, em função de um programa vinculado e aprovado pela prefeitura chamado de "Projeto Um Milhão de Árvores". 
Figura 51- Eucaliptos plantados na área do aterro controlado.

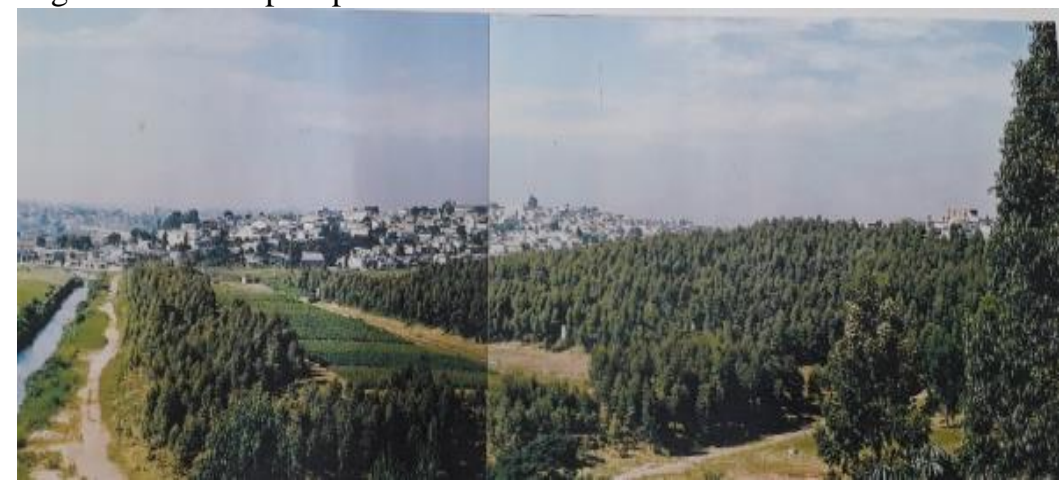

Extraído de: CETESB, 1998.

O programa visava ampliar a quantidade de verde na cidade em vias públicas e em regiões periféricas (FOLHA DE SÃO PAULO, 1995; BARROS, 2011).

Em 2001, a SVMA em cooperação com Companhia de Gás de São Paulo - COMGÁS realizou uma campanha com medição do gás metano, que demonstrou que ainda havia uma quantidade significativa de gás no aterro, mas não certamente para seu aproveitamento para fim energético e/ou comercialização de crédito de carbono (MORINAGA, 2007). Também foi detectado que a maioria dos drenos existentes não estava funcionando adequadamente.

Em 2002 é oficialmente criado o Parque Municipal Jardim Primavera, por meio da Lei Municipal N. 13.308, de 31 de janeiro de 2002, que destaca sobre a implantação:

Parágrafo único - A implantação do parque será executada de acordo com estudos técnicos elaborados pela CETESB, que comprovam sua adequação do ponto de vista ambiental (SÃO PAULO (cidade), 2002).

Além disso, de acordo com a lei o prazo para a adequação das condições sanitárias e ambientais do local era de 60 dias para sua regulamentação e 180 dias para dar início às obras de construção do Parque. Também, chamava a atenção para os equipamentos e os programas que o parque deveria ter, como:

I - área de lazer própria para crianças e adolescentes;

II - área de lazer para adultos até a $3^{\mathrm{a}}$ idade;

III - área de lazer destinada a pessoas portadoras de deficiências físicas, projetada por técnicos especializados na área;

IV - ciclovia;

V - trilha para caminhada;

VI - quadras poliesportivas;

VII - espaço destinado a atividades culturais, shows, apresentações diversas; 
VIII - quiosques para piqueniques;

IX - área destinada à leitura, arborizada e com bancos;

$\mathrm{X}$ - viveiro de plantas estruturado para fornecer mudas à população;

XI - vegetação arbórea de grande porte correspondente à $40 \%$ da área total do parque, distribuída de forma a garantir sua existência em toda a área;

XII - equipamentos sanitários em número proporcional à área e potencial de utilização;

XIII - equipamento preventivo para atendimento médico de emergência (SÃO PAULO (cidade), 2002).

\subsubsection{Início da Investigação Ambiental}

No ano de 2004, a CETESB apontou à SVMA que somente depois de realizada uma investigação detalhada no local que seria possível identificar problemas ambientais da área e, a partir de então, determinar medidas de recuperação e mitigação a adotar.

A SVMA, ainda em 2004, por meio do GTAC realizou vistoria no local constatando a existência de drenos sem manutenção, que possibilitaria o entupimento e o acúmulo de gases. Além disso, tendo em face a suspeita de contaminação considerou imprescindível a realização de estudos completos a fim de apurar as medidas de intervenção necessárias.

No ano de 2007, a SVMA contratou uma empresa de consultoria para executar os serviços de Avaliação Ambiental na área do antigo aterro controlado Jacuí, visando posteriormente implantar o Parque Municipal Jardim Primavera (WEBER, 2007).

Este estudo ambiental foi realizado em duas fases. A primeira foi executada no período de 29/03/2007 a 16/05/2008, e envolveu os serviços e estudos do reconhecimento da situação geotécnica, investigações de emanação dos gases e a investigação confirmatória (análises laboratoriais de solo e água subterrânea). E a segunda fase, foi realizada no período de 20/08/2007 a 01/04/2008, na qual foi realizada a investigação detalhada, elaboração da avaliação de risco e propostas de remediação (SVMA, 2012).

De acordo com as inspeções realizadas não constaram condições de instabilidade, erosão e vazamento de percolados superficiais provenientes do aterro, assim como, resíduos expostos. Também foi identificado que as instalações de drenagem e tratamento do chorume estavam desativadas.

A geologia local foi identificada por uma sequência de deposição aluvionar e de planície de inundação, resultando no empilhamento por pacotes de areia, de forma intercalada com a presença de sedimentos mais finos como siltes e argilas e de coloração variada (WEBER, 2008). 
Os resultados obtidos na etapa I indicaram contaminação na água subterrânea e no solo, listados no quadro 9. Houveram indicações de impacto do aquífero em estudo, em especial na porção jusante ao aterro em sentido do córrego Jacu por chorume.

Quadro 9- Resultados obtidos na Etapa I
\begin{tabular}{|c|l|}
\hline Compartimento Ambiental afetado & \multicolumn{1}{|c|}{ Contaminantes identificados } \\
\hline Água Subterrânea & $\begin{array}{l}\text { Metais (alumínio, bário, boro, cromo total, } \\
\text { ferro, manganês, nitrato) } \\
\text { coliformes fecais decorrente da antiga estação } \\
\text { de tratamento de efluentes (ETE) e coliformes } \\
\text { totais. }\end{array}$ \\
\hline Solo & $\begin{array}{l}\text { Gás Metano. Presente também nos drenos e } \\
\text { em caixas de visitas da Sabesp dispostas nos } \\
\text { arredores do imóvel. }\end{array}$ \\
\hline
\end{tabular}

Extraído de: WEBER, 2008; GEOINTEGRA, 2013. Elaborado pela autora.

Importante enfatizar que, naquele contexto, o gerenciamento de áreas contaminadas já tinha sido iniciado pelo município, com estudos e análises realizados de acordo com os parâmetros exigidos pela CETESB.

$\mathrm{Na}$ etapa II visando ampliar as amostragens e análises laboratoriais foram realizadas 36 sondagens investigativas, que exigiram a instalação de poços multiníveis, e poços de monitoramento. Foi identificado a contaminação no solo e na água subterrânea listados no quadro 10.

Quadro 10- Resultados obtidos na Etapa II.
\begin{tabular}{|c|l|}
\hline Compartimento Ambiental afetado & \multicolumn{1}{|c|}{ Contaminantes identificados } \\
\hline Água Subterrânea & $\begin{array}{l}\text { Metais (alumínio, bário, cádmio, chumbo, } \\
\text { cobalto, cromo total, ferro, manganês, níquel) } \\
\text { Coliformes fecais e totais }\end{array}$ \\
\hline Solo & Metais (vanádio, ferro e alumínio) \\
\hline
\end{tabular}

Extraído de: WEBER, 2008; GEOINTEGRA, 2013. Elaborado pela autora.

Com os dados obtidos nas etapas I e II em 2008, elaborou-se a avaliação de risco à saúde humana, considerando três cenários diferentes, vias de exposição e receptores, sendo:

- Cenários: Atual (aterro desativado), futuro (parque) e hipotético (parque);

- Receptores: Trabalhadores comerciais, seguranças e trabalhadores de obras; Crianças, Jovens, Adultos e Idosos;

- Vias de Exposição: Ingestão, contato dérmico e inalação

Os resultados obtidos da análise indicaram riscos nos três cenários diferentes, suas vias de exposição e os receptores, representados no quadro 11. 
Quadro 11- Resultados da avaliação de risco à saúde humana no aterro desativado Jacuí.

\begin{tabular}{|c|c|c|c|}
\hline Cenários & Receptores & Vias de Exposição & $\begin{array}{c}\text { Risco } \\
\text { Toxicológico }\end{array}$ \\
\hline $\begin{array}{c}\text { Atual } \\
\text { Aterro } \\
\text { desativado) }\end{array}$ & $\begin{array}{c}\text { Trabalhadores comerciais, } \\
\text { seguranças e trabalhadores de } \\
\text { obras }\end{array}$ & $\begin{array}{c}\text { Ingestão acidental, } \\
\text { inalação de partículas e } \\
\text { contato dérmico com solo. }\end{array}$ & Alumínio \\
\hline $\begin{array}{c}\text { Futuro } \\
\text { (Parque) }\end{array}$ & Crianças & Ingestão acidental de solo & Alumínio e Ferro \\
\hline $\begin{array}{c}\text { Hipotético } \\
\text { (Parque) }\end{array}$ & $\begin{array}{c}\text { Crianças, Jovens, Adultos e } \\
\text { Idosos }\end{array}$ & $\begin{array}{c}\text { Ingestão e contato dérmico } \\
\text { com água subterrânea }\end{array}$ & $\begin{array}{c}\text { Alumínio, Ferro e } \\
\text { Manganês }\end{array}$ \\
\hline
\end{tabular}

Extraído de: WEBER, 2008. Elaborado pela autora.

Além disso, este estudo na fase II ratificou a presença de gás metano no solo, concluindo haver risco eminente decorrente das concentrações superiores a 2000 ppm. A exceção foi um poço cacimba aterrado existente na Rua Grinalda de Noiva, com concentrações acima de 10.000ppm em condições de explosividade (WEBER, 2007; SVMA, 2012; GEOINTEGRA, 2013). Diante dos resultados, a consultoria ambiental indicou medidas mitigadoras para reutilização da área de estudo como parque, apresentadas no quadro 12.

Quadro 12- Medidas mitigadoras recomendadas para reutilização da área.

\begin{tabular}{|l|l|}
\hline \multicolumn{2}{|c|}{ Medidas Mitigadoras } \\
\hline $\begin{array}{l}\text { Recobrimento do solo com uma camada } \\
\text { de pelo menos 0,50 m de solo limpo, } \\
\text { compactado e argilosa. }\end{array}$ & $\begin{array}{l}\text { Plantio de gramíneas acima das cavas ou locais } \\
\text { onde houve a deposição de resíduos. }\end{array}$ \\
\hline $\begin{array}{l}\text { Manutenção da topografia do aterro, de } \\
\text { modo a minimizar a movimentação de } \\
\text { terra. }\end{array}$ & $\begin{array}{l}\text { Edificações fechadas deverão ser construídas } \\
\text { fora da área onde houve deposição de resíduos } \\
\text { e com elementos vazados. }\end{array}$ \\
\hline $\begin{array}{l}\text { Restrição ao plantio de vegetação arbórea } \\
\text { de grande porte e de espécies frutíferas. }\end{array}$ & $\begin{array}{l}\text { Restrição do uso água subterrânea para } \\
\text { consumo humano. }\end{array}$ \\
\hline $\begin{array}{l}\text { Utilização de equipamentos de proteção } \\
\text { individual (EPIs) adequados pelos } \\
\text { trabalhadores de obras e funcionários com } \\
\text { acesso à área. }\end{array}$ & $\begin{array}{l}\text { Instalação Emergencial de SVE pontual em } \\
\text { dois poços de monitoramento (PM) e na } \\
\text { residência da rua Grinalda de Noiva, na antiga } \\
\text { cacimba aterrada. }\end{array}$ \\
\hline $\begin{array}{l}\text { Preservação dos drenos e poços de } \\
\text { monitoramento existentes. }\end{array}$ & $\begin{array}{l}\text { Instalação de Sistema de Extração de Vapores } \\
\text { (SVE). }\end{array}$ \\
\hline $\begin{array}{l}\text { Selamento de fissuras do aterro com } \\
\text { material impermeabilizante. }\end{array}$ & $\begin{array}{l}\text { Monitoramento semestral da qualidade da água } \\
\text { subterrânea. }\end{array}$ \\
\hline
\end{tabular}

Extraído de: WEBER, 2008; SVMA, 2012. Elaborado pela autora.

Com a reinvindicação insistente dos moradores ao arredor do aterro para a transformação em parque, a prefeitura retomou o projeto de implantação em 2008. Entretanto, em função da confirmação da contaminação do solo e da água subterrânea, foi definido que o projeto seria desenvolvido em duas etapas.

Inicialmente, a primeira fase correspondia ao local que não recebeu resíduos, o qual seria utilizado para instalação de alguns equipamentos de uso direto, como playground, 
quiosques e churrasqueiras, devido à menor probabilidade de apresentar riscos à saúde humana, (figura 52).

Esse trecho da área municipal está situado junto à Rua Perpetua do Campo com cerca de $14.400 \mathrm{~m}^{2}$, existindo mais declividades acentuadas do que no restante do terreno (BARROS, 2011). Ainda em 2008, foi implantada cerca em todo perímetro do aterro controlado. E na segunda fase, por ser no local em que ocorreu o descarte dos resíduos, estava prevista a construção de pistas para bicicletas, caminhadas, uma quadra poliesportiva e um espaço com usos múltiplos para eventos (RAMIRES; VITOR, 2010).

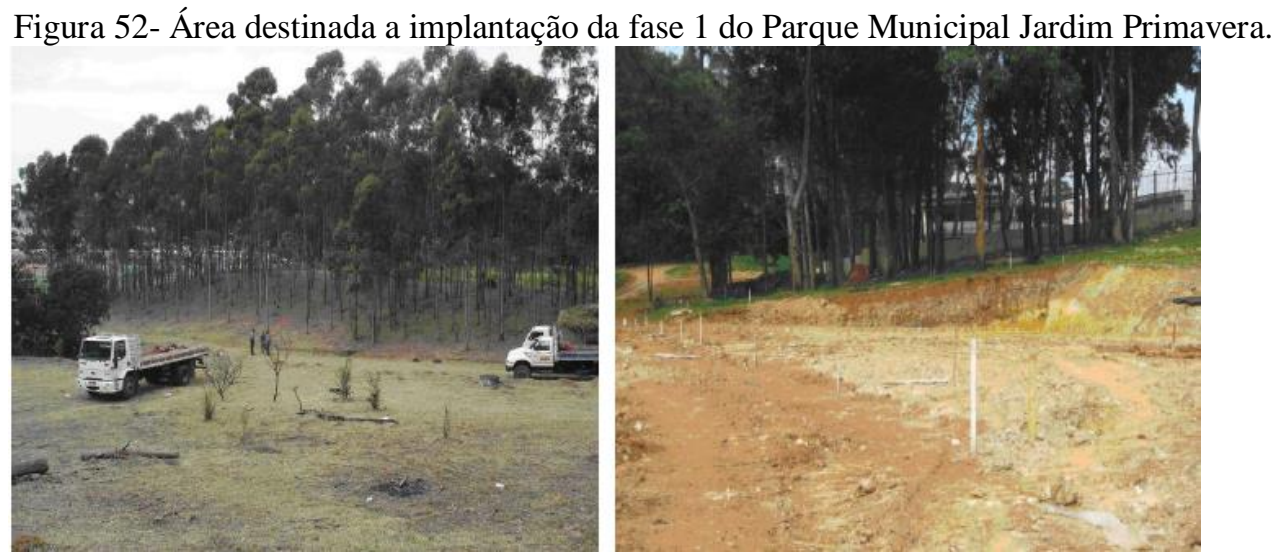

Extraído de: RAMIRES; VITOR, 2010.

Em setembro de 2008, a implantação da obra fase 1 foi retomada. Mas, no decorrer da demolição foi identificada uma antiga caixa de contenção e tratamento do chorume com resíduo de lodo, que foi necessário ser encaminhado para a destinação adequada, não prevista no contrato. Desta forma, foi necessário interromper os trabalhos e o cancelamento do contrato, no mesmo ano.

\subsubsection{Estudos Ambientais Complementares}

Em continuidade ao caso, a SVMA ainda em 2008 entrou com o processo licitatório para a contratação de serviços de instalação do sistema de extração de vapores (SVE) na porção sudoeste da área do antigo aterro, mas em função da viabilidade econômica não foi possível a execução da mesma de imediato (SVMA, 2012).

Ainda assim, perante a cobrança insistente dos moradores dos arredores para a construção do parque e mais a adoção de algumas diretrizes aliadas aos estudos executados, as obras da fase 1 (figura 53) foram retomadas em novembro de 2010. Seu custo previsto foi de 
R \$ 1,74 milhão e prazo de 300 dias para sua execução, que foi finalizada em 2011. Nesse mesmo ano, iniciou-se a elaboração do projeto da fase 2 pelo DEPAVE, com previsão de abertura de licitação no mesmo ano (BARROS, 2011).

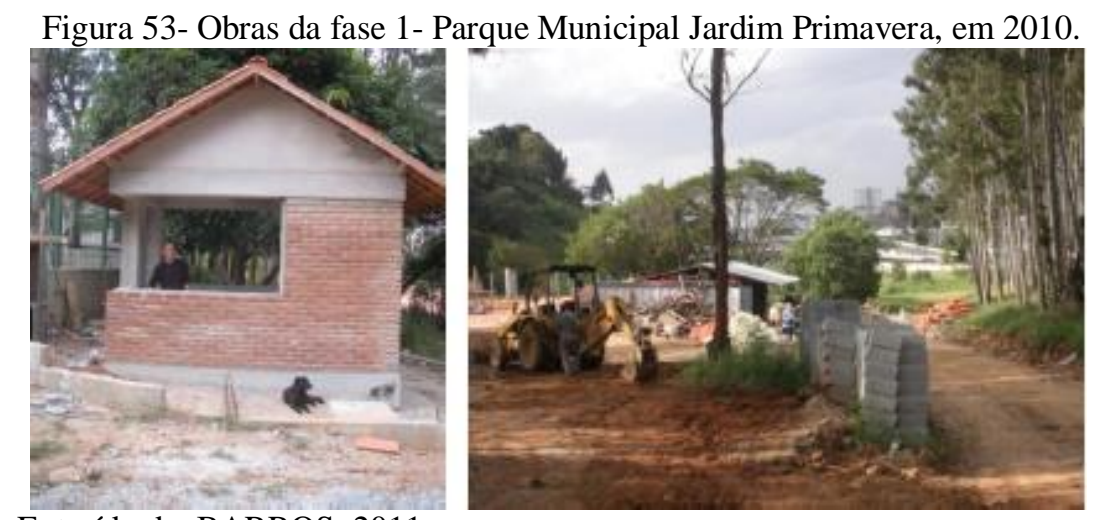

Extraído de: BARROS, 2011.

Em continuidade ao caso, em 2012, foi autuado um processo administrativo para a contratação de serviços, por meio de certame licitatório, de implantação do sistema de extração de vapores na porção sudoeste da área do antigo aterro controlado. No entanto, após pesquisa mercadológica sobre o orçamento para a implantação do sistema, a SVMA verificou e concluiu pela inviabilidade econômica de tal procedimento (SVMA, 2012).

Diante da providência não realizada como imprescindível para mitigar o risco, o MPSP, no ano de 2012, ingressou com uma Ação Civil Pública em defesa do Meio Ambiente nos moldes da Lei n.7347/1985 (disciplina a Ação Civil Pública de Responsabilidade por Danos Causados ao Meio Ambiente e dá outras providências) contra a Prefeitura de São Paulo, exigindo a suspensão total de qualquer obra tendente à implantação do parque.

O MPSP concedeu essa liminar com a obrigação de fazer a exaustão dos gases presentes no solo, enquanto não constatada pela CETESB ou pelo GTAC a inexistência de risco ambiental sob pena de multa diária no valor de dez mil reais (MPSP, 2012).

Posteriormente em 2013, foi proposto pela SVMA conforme parecer técnico $\mathrm{n}^{\circ}$ 149/GTAC/2013, um monitoramento dos possíveis gases existentes na área por um período de 2 anos. Esse monitoramento serviu como medida inicial para atualização do cenário atual, e para estabelecer os procedimentos a serem aplicados na área, visando à inexistência de risco à saúde dos funcionários e dos frequentadores do Parque Primavera (SVMA, 2017).

Dessa forma, após reuniões com DEPAVE e DECONT (Departamento de Controle da Qualidade Ambiental), uma empresa apresentou um projeto técnico de compensação 
ambiental- Termo de Ajustamento de Conduta (TAC) assumindo a obrigação de contratar e custear os serviços de avaliação ambiental da área do aterro Jacuí, o qual foi realizado por empresa de consultoria ambiental (SVMA, 2017).

A contratada realizou os serviços da fase I no período de 29/01/2014 a 05/02/2014, que contemplava a realização de Soil Gas Survey (60 pontos de medição) e a instalação de 40 poços de monitoramento de gases, figura 54.

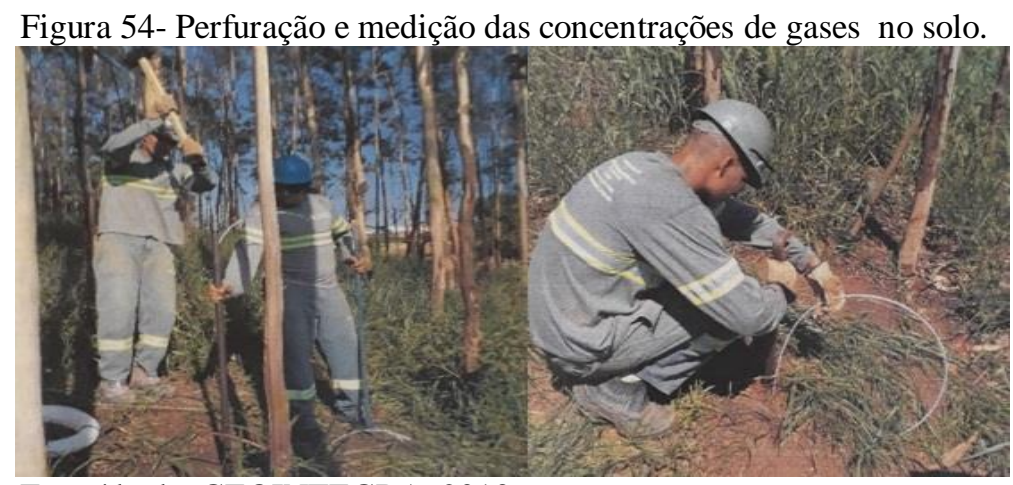

Extraído de: GEOINTEGRA, 2013.

As medições das concentrações de compostos orgânicos voláteis e metano foram realizadas nas instalações subterrâneas localizadas no entorno da área de estudo (redes de esgoto, água, gás, drenagem e telefonia), além da entrada e saída de tubulações das edificações existentes, representado na figura 55 (GEOINTEGRA, 2013).

Figura 55- Medição dos gases nas instalações existentes.

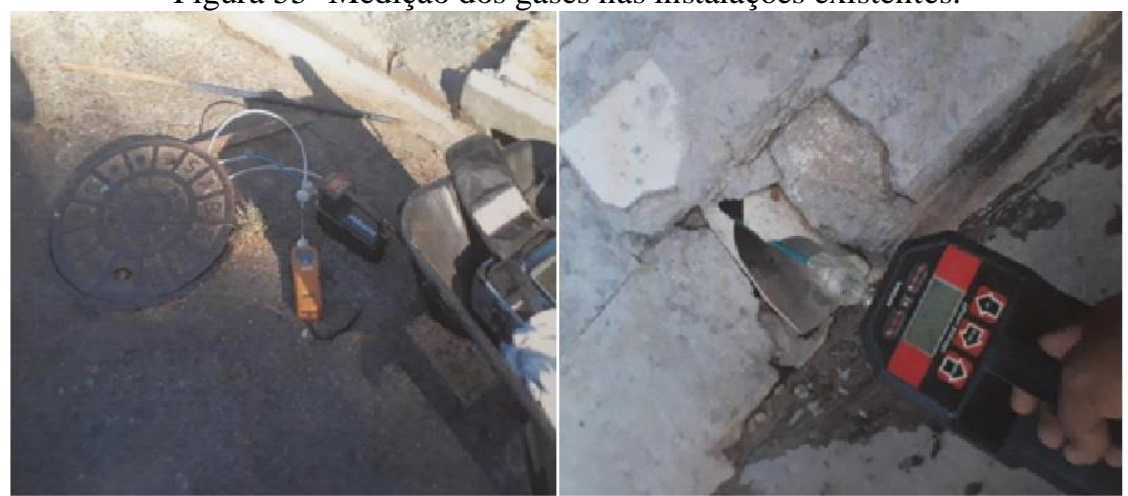

Extraído de: GEOINTEGRA, 2013.

Os resultados das análises obtidas de compostos orgânicos voláteis no solo apresentaram concentrações acima dos padrões adotados para benzeno, tetracloroeteno, clorobenzeno, etilbenzeno, n-propilbenzeno, 1,3,5-trimetilbenzeno e 1,2,4-trimetilbenzeno. As medições de metano realizadas nas três campanhas apontaram concentrações acima do 
LEL (Lower Explosive Limite), sendo: 22,5\%, $20 \%$ e 7,5\% acima do LEL com potencial explosivo (GEOINTEGRA, 2014).

$\mathrm{Na}$ data de 26/02/2014, foi coletada uma amostra composta de solo produzidos pelas sondagens para a caracterização e destinação adequada dos resíduos, como estabelece a ABNT NBR 10004/2004 (GEOINTEGRA, 2013).

O CADRI (Certificado de Movimentação de Resíduos de Interesse Ambiental) foi emitido pela CETESB no dia 30/07/2014. O resíduo foi caracterizado em solo de escavação e classificado como IIB Inerte (CETESB, 2014).

Além disso, ainda para a fase II foi acompanhado o monitoramento de gases pelo período de 2 anos (2014 a 2016) com apresentação de relatórios trimestrais com seus respectivos resultados, além do plano de intervenção e a avaliação de risco atualizada (GEOINTEGRA, 2013).

\subsubsection{Situação Ambiental atual da área}

Tendo em vista o cumprimento das 24 campanhas mensais de monitoramento de gases/vapores no solo desenvolvidas como estabelecido para a área do aterro controlado Jacuí, foi elaborado o plano de intervenção e análise de risco à saúde humana, de forma a viabilizar a implantação do Parque Municipal Jardim Primavera.

Destaca-se que atualmente toda área se encontra interditada pelo Ministério Público, por meio de Ação Civil Pública na $2^{\mathrm{a}}$ Vara da Fazenda Pública- Foro Central, em função da presença de gases no interior do terreno (SVMA, 2017; SVMA, 2017a).

O estudo de avaliação de risco à saúde humana, considerou os caminhos da exposição para ambiente aberto e fechado, sendo:

- Cenário Futuro: Parque.

- Receptores: trabalhadores comerciais; trabalhadores de obras civis e de escavação envolvidos na implantação e operação do futuro parque; residentes urbanos vizinhos (adultos e crianças) e usuários recreacionais (adultos e crianças).

- Vias de Exposição: Inalação de vapores no solo em ambientes abertos e fechados.

Uma vez que na área não haverá a construção de edificações, foi identificado risco a saúde humana para o caminho de exposição por inalação de vapores em ambientes abertos para trabalhadores comerciais, como mostra o quadro 13. 
Além disso, foi observada a presença de gás metano, principalmente na região das antigas cavas (GEOINTEGRA, 2016).

Quadro 13- Risco identificado para saúde humana em ambientes abertos no parque.

\begin{tabular}{|c|c|c|c|}
\hline Cenário & Receptores & Vias de Exposição & $\begin{array}{c}\text { Risco Toxicológico } \\
\text { Ambiente Aberto }\end{array}$ \\
\hline $\begin{array}{c}\text { Futuro } \\
\text { Parque }\end{array}$ & $\begin{array}{c}\text { Trabalhadores de } \\
\text { obras civis e de } \\
\text { escavação }\end{array}$ & $\begin{array}{c}\text { Inalação de Vapores no } \\
\text { solo }\end{array}$ & $1,1,2$ - Tricloroetano \\
\hline
\end{tabular}

Extraído de: GEOINTEGRA, 2016. Elaborado pela autora.

Diante do risco identificado foi elaborado o plano de intervenção com as medidas que devem ser tomadas (quadro 14), visando a implantação e operação do Parque Municipal Jardim Primavera.

Quadro 14- Medidas do Plano de Intervenção para a área.

\begin{tabular}{|c|}
\hline Isolamento Físico \\
Cercamento e isolamento e medidas de restrição de acesso à área.
\end{tabular}

\section{Cobertura Final}

Implantar capeamento através de solo fértil de natureza argilosa em toda a área, favorecendo o desenvolvimento da vegetação, e eliminando os riscos associados ao contato com o solo; Implantar cobertura vegetal para minimizar os processos erosivos;

Manter e monitorar as estruturas de captação, condução e descarte dos excedentes hídricos existentes;

Manter os drenos de gases existentes, assim aliviando a pressão dos gases gerados no subsolo.

Restrições Institucionais
Água subterrânea: Restrição ao uso e consumo de água subterrânea;

Não é permitido a instalação de poços de captação em quaisquer profundidades, diâmetro ou perfis construtivos; construção de lagos e lagoas abaixo do nível do solo; construção de reservatórios enterrados e rebaixamento ou intervenções no lençol freático.

\section{Solo}

Cobertura de toda a área com solo de natureza argilosa e de baixa condutividade hidráulica; Durante a implantação e operação do Parque, escavações devem ser evitadas de modo a prevenir a exposição dos trabalhadores comerciais e de obras civis e usuários recreacionais; Em caso de necessidade, eventuais escavações poderão ser realizadas desde que sejam adotados de EPI adequados.

\section{Programa de Monitoramento}

Avaliação Semestral: estabilidade geotécnica dos dez marcos topográficos de recalque; avaliação dos parâmetros de interesse da água subterrânea; avaliação de metano no ar ambiente; análise de compostos orgânicos voláteis (COV) no ar em ambientes abertos e fechados; instalação de poço no monitoramento na rua Grinalda de Noiva para na análise de COV.

Continua...

\section{Metano}

Restrição ao uso do subsolo e ambientes fechados;

Não poderão ser realizadas instalações subterrâneas como tubulações, eletrodutos, dutos, caixas de passagem e inspeção;

Destruir a antiga cava de captação de percolado, evitando acumulo de gás em seu interior;

Restrição as construções ao nível do solo que configurem ambientes fechados como salas 


administrativas, banheiros, depósitos, guaritas entre outros;
Implantar um isolamento que contemple um raio de 4 metros ao redor de cada um dos 26
drenos de gases existentes, através de um cercamento em altura de 2 metros a partir do solo,
garantindo a restrição de acesso e evitando aproximação dos usuários do parque;
Restrição a área à trabalhadores de obras civis e de escavação em ambientes abertos, devido
a concentração de 1,1,2- tricloroetano identificada.

Extraído de: GEOINTEGRA, 2016. Elaborado pela autora.

A partir dos resultados obtidos durante os 24 meses de monitoramento das concentrações de gases e vapores no aterro controlado, ficou indicado ser seguro a implantação e operação do Parque Municipal Jardim Primavera nessa área, desde que atendidas integralmente as adequações, restrições, controles e monitoramento apresentados no plano de intervenção. Além disso, deverá ser realizado o registro das medidas previstas conduzido com periocidade semestral, por meio de relatórios técnicos contemplando as atividades desenvolvidas no último período.

Ao final deste processo mantido, o cenário ambiental caracterizado, a PMSP em fevereiro de 2017 solicitou à CETESB a emissão do Termo de Reabilitação de Área para Uso Declarado.

Em maio de 2017, a CETESB aprovou o plano de intervenção para reutilização da área através do Parecer Técnico n 014/17/CA (CETESB, 2017) e também apresentou Parecer Técnico favorável no 014/CAAR/2017 para a reabertura de forma parcial da Fase I do Parque Municipal Jardim Primavera, com acesso ao público construída, figura 56 (CETESB, 2017a).

Figura 56- Fase I finalizada do Parque Municipal Jardim Primavera.

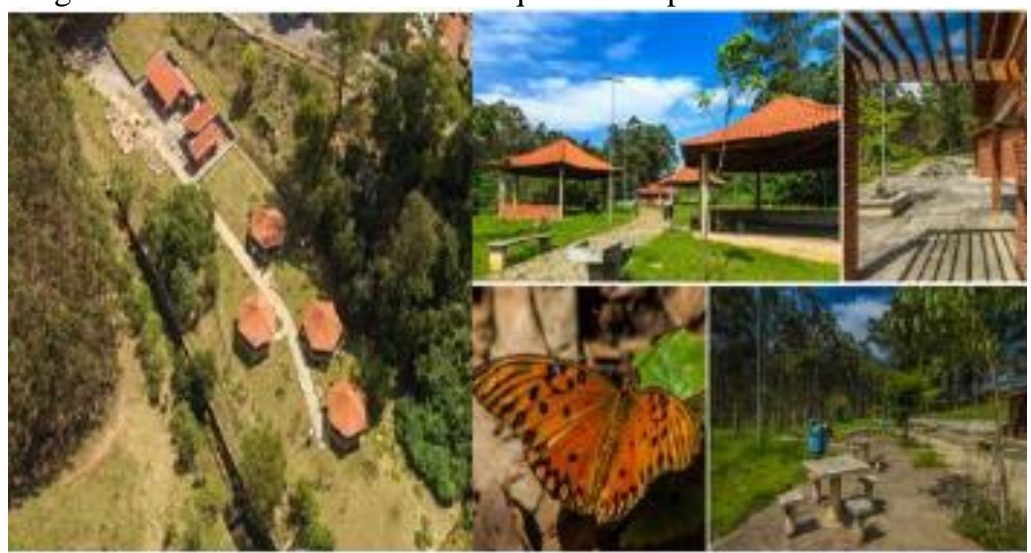

Extraído de: 〈https://www.prefeitura.sp.gov.br/cidade/secretarias/meio_ambiente/parques>. Acesso em: 20 ago. 2018.

Tendo em vista que a área ainda se encontra interditada pelo Ministério Público por meio de Ação Civil Pública, mesmo passados quatro anos que foi encerrado o processo de 
monitoramento dos gases, em dezembro de 2018 foi realizada a perícia no local com a presença da Promotoria do Meio Ambiente da Capital do Ministério Público e do Município de São Paulo, seus assistentes técnico pericial e os advogados envolvidos no caso.

Desta forma, aguarda-se a conclusão final do laudo pericial realizado que até o presente momento não há informações sobre as providências adotadas, mesmo que tenha ficado evidente que a área da fase 1 está apta para sua reabertura de maneira parcial, e a inexistência de riscos à saúde humana aos futuros usuários na área da fase 2.

\subsubsection{Atores envolvidos no caso}

No processo de requalificação de áreas contaminadas é essencial identificar os principais grupos interessados no processo, uma vez que abrangem campos de ação variadas como planejamento urbano, habitação, meio ambiente, licenciamento, economia e participação civil.

Esses principais grupos são denominados de Stakeholders que são as partes interessadas, atores, grupos ou indivíduos que têm algum tipo de envolvimento direto no tema, que podem afetar ou ser afetados pelos objetivos de uma organização pública ou privada (MARKER, 2013. p. 71). Eles estão divididos em:

- Setor Público (bancos públicos de desenvolvimento; ministérios da habitação, cidades e meio ambiente; secretaria municipal de planejamento; secretaria municipal de meio ambiente; secretaria municipal de habitação).

- Setor Privado (construtoras; incorporadoras; bancos privados; universidades; sociedades público-privadas de desenvolvimento; sindicatos e representações profissionais).

- Sociedade Civil (população, ONGs e comunidades; proprietários e usuários de terrenos).

Para promover ou viabilizar o processo de requalificação de uma área contaminada é de grande importância a participação conjunta desses grupos de maneira colaborativa, o que significa ganho para todas as partes, com um único objetivo. 
No caso do Parque Municipal Jardim Primavera, pode-se identificar que os principais grupos participantes no processo de requalificação foram: o Ministério Público, SVMA e CETESB, ou seja, todos pertencentes ao setor público.

\subsubsection{Observações gerais sobre o estudo de Caso 1}

A área contaminada do antigo aterro controlado Jacuí se enquadra e atende as propostas para sua requalificação em parque público pretendida pela municipalidade, uma vez que:

1. Realizou e cumpriu todo o procedimento do gerenciamento ambiental de Acs no imóvel, conforme estabelecido na DD No 103/2007/CE e o Decreto Estadual 59.263/2013, uma vez que a análise técnica foi realizada no período anterior à publicação da DD038/2017/C;

2. Constatou a inexistência de risco à saúde humana em ambiente aberto para os receptores e futuros usuários do parque;

3. Apresentou todas as medidas restritivas que devem ser realizadas durante a implantação e a futura ocupação do mesmo;

4. Obteve-se o plano de intervenção para reutilização da área contaminada aprovada pela CETESB, podendo a municipalidade responsável emitir as autorizações para demolição e construção, em caso de necessidade, conforme estabelecido DD038/2017/C;

5. Elaborou o projeto básico para a fase II do parque, sem a construção de edificações, instalações subterrâneas e espaços confinados, evitando contato dérmico com o solo e resíduos, assim como o acúmulo de gás metano no subsolo;

6. Restringiu o uso e a captação da água subterrânea, além do plantio e consumo de alimentos na área;

7. Obteve-se o parecer favorável da CETESB para uso declarado quanto à utilização da fase 1 já construída com acesso ao público, desde que mantidas a restrições das escavações.

8. Garante o desenvolvimento e uso sustentável do solo incentivando a reutilização da área contaminada, e evitando o espalhamento urbano por novas áreas. 


\subsection{ESTUDO DE CASO 2: PARQUE ESTADUAL VILLA-LOBOS}

\subsubsection{Localização da área de estudo}

O Parque Estadual Villa-Lobos está localizado no bairro Alto de Pinheiros, na zona oeste do município de São Paulo. Está situado na Avenida Professor Fonseca Rodrigues, 2001 e possui aproximadamente $732.000 \mathrm{~m}^{2}$, figura 57 (WEBER, 2013).

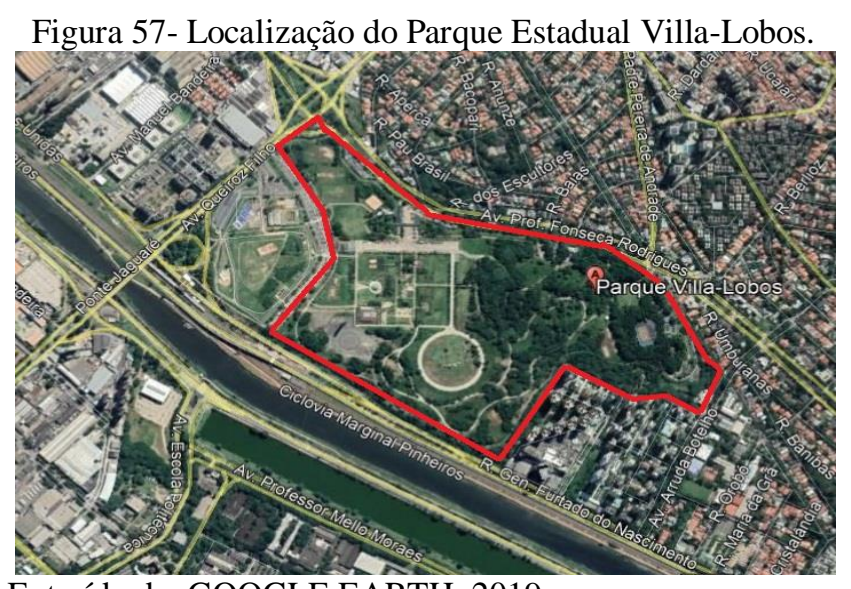

Extraído de: GOOGLE EARTH, 2019.

Está inserida na Bacia do Alto Tietê pertencendo à Macrozona de Estruturação e Qualificação Urbana e na Macroárea de Urbanização Consolidada. Apresenta um padrão elevado de urbanização, forte saturação viária e elevada concentração de empregos, comércios e serviços, assim como zonas exclusivamente residenciais (SÃO PAULO (cidade), 2014); SMDU, 2016).

O Parque Estadual Villa-Lobos já se encontra finalizado e pertence ao governo do estado. Seu zoneamento se classifica como ZEPAM, e o seu entorno é predominantemente enquadrado em zona mista e zona de centralidade.

\subsubsection{Uso e Ocupação do solo}

$\mathrm{Na}$ área ocupada pelo parque, situada em antiga planície de inundação do Rio Pinheiros, o processo de ocupação iniciou-se em 1958. Apresentava vegetação rasteira, alguns caminhos de movimento de terra e o córrego Boaçava, ilustrado na figura 58. 
No seu entorno havia loteamentos e ocupação residencial, além de alguns empreendimentos em processo de construção, como a Raia Olímpica da USP, terrenos vazios e dois galpões industriais (WEBER, 2013).

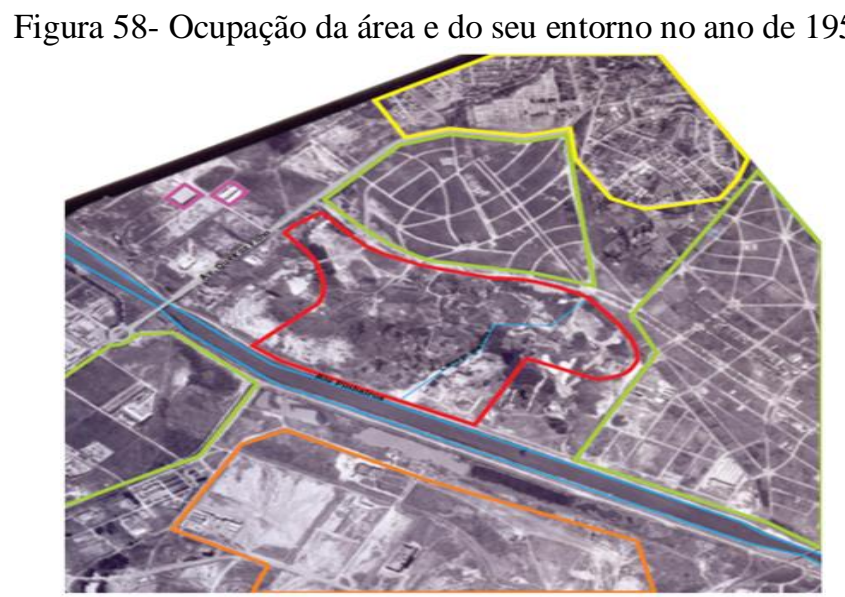

Legenda- Cores: Vermelho- Área do Parque Villa-Lobos; Marrom: movimento de Terra; Verde: área verde/loteamento; Azul: Corpo d'água; Amarelo: residências; Roxo: indústrias; Laranja: USP. Extraído de: WEBER, 2013.

No ano de 1968, a área apresentava trechos de vegetação mais adensados, e na sua porção sul, próximo ao Rio Pinheiros, um grande movimento de terra em valas e estradas utilizadas para a extração de areia, figura 59.

Figura 59- Movimentação de Terra, na parte sul da área.

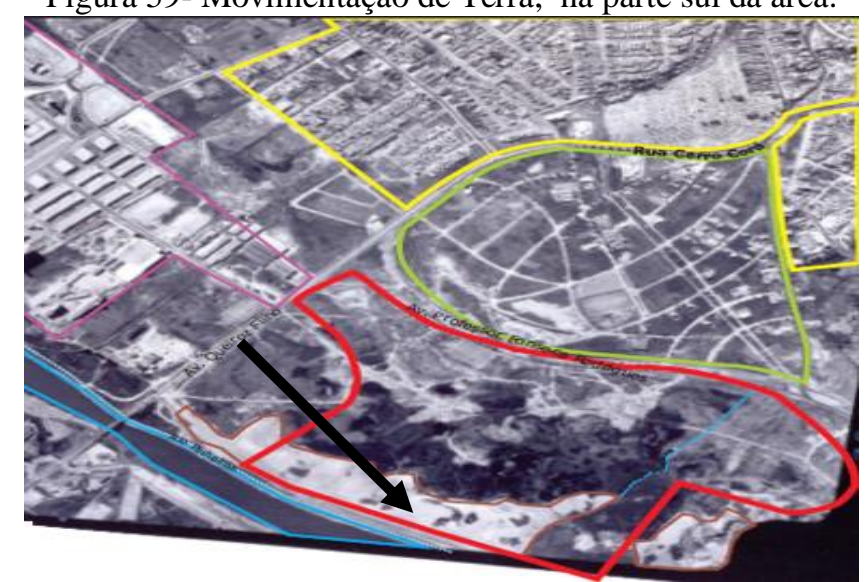

Legenda- Cor Marrom: movimento de Terra. Extraído de: WEBER, 2013.

Segundo levantamento histórico, os taludes formados na área variavam de 5 a 11 metros de altura, em formato de pilhas na porção norte. Também haviam na porção oeste, pequenas lagoas. O seu entorno, ao norte, já se apresentava mais adensado com ocupação residencial e loteamentos, a oeste a expansão da ocupação industrial, e ao sul margeando do 
Rio Pinheiros, a implantação da Estrada Ferroviária-CPTM, atual linha Esmeralda (WEBER, 2013).

Posteriormente, no ano de 1974, no trecho ao sul da área foi feita a recomposição de vegetação em uma cava, e na porção nordeste, uma nova área de movimento de terra, figura 60. Em 1977 a cava apresentava-se completamente aterrada, na qual também foi possível notar duas balsas de dragagem de sedimentos do Rio Pinheiros, em frente à área do Parque, e sinais de material dragado lançado em lagoa formada na parte central, ao lado da antiga cava de extração de areia.

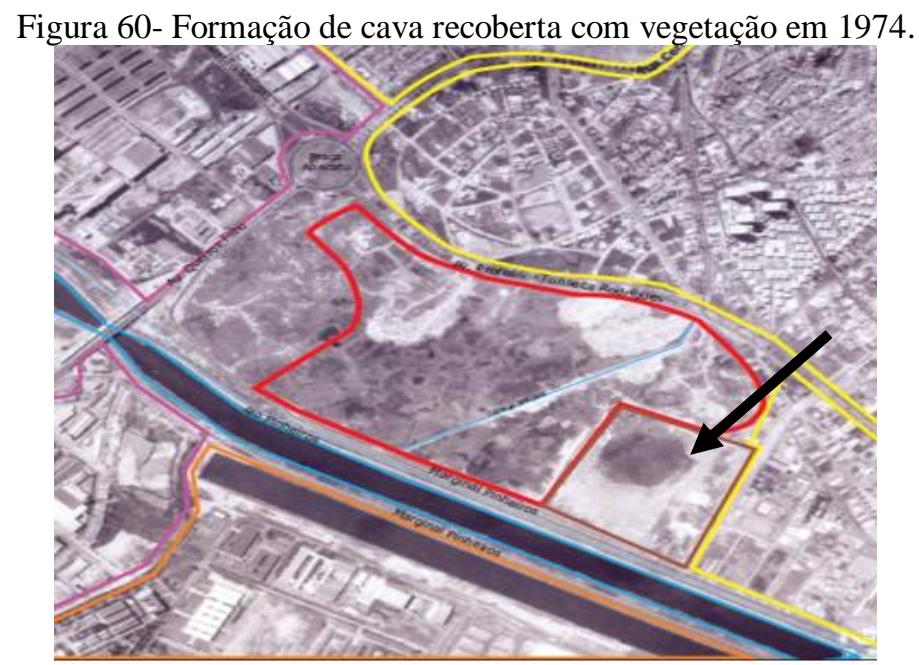

Legenda: Mancha escura: sinais da disposição de material dragado. Extraído de: WEBER, 2013.

Quanto ao seu entorno, ao norte e leste encontrava-se completamente ocupado por residências, ao sul a Cidade Universitária instalada, bem como a Raia Olímpica e o aumento da ocupação industrial a oeste. Também é possível observar a Avenida da Marginal do Rio Pinheiros já implantada.

Em 1986, observa-se o aparecimento de novos caminhos formados dentro da área e a formação de diques de decantação de material dragado do rio. Também é identificado na área central, um aterro de solo de elevadas proporções, aparentemente sem a presença de entulhos de construção e na porção noroeste é notado um trecho com ocupação residencial com campo de futebol, figura 61 .

Figura 61- Intensificação do movimento de terra na parte central da área. 


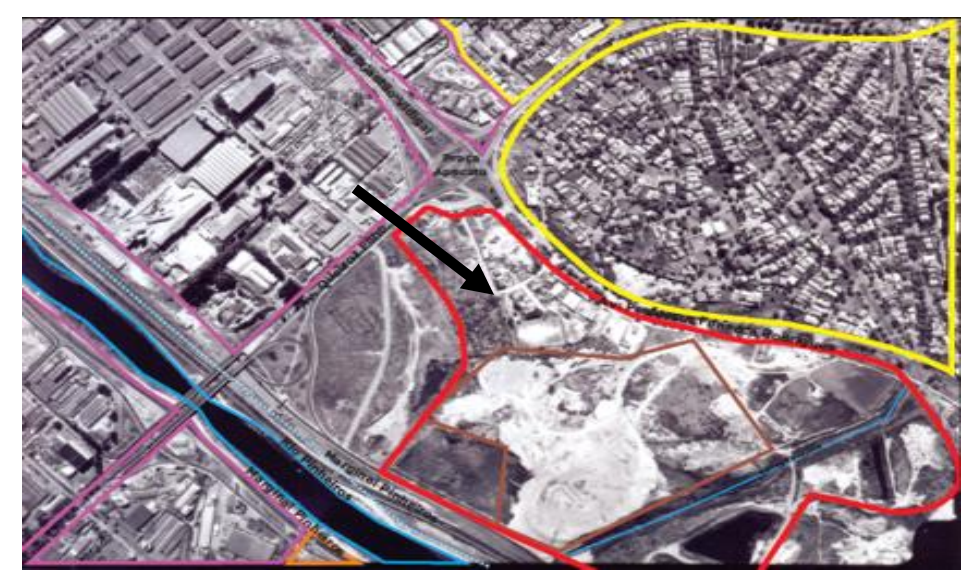

Legenda: Parte Noroeste da área- ocupação residencial. Extraído de: WEBER, 2013.

Nesse período, próximo ao local onde hoje funciona a administração do parque, foi identificada uma área que recebia materiais metálicos para reciclagem, aparentemente sucatas provenientes de tanques de armazenamento subterrâneo (WEBER, 2013). O entorno nessa época apresentava as mesmas características que em 1968, porém com aumento da ocupação.

Ainda em 1986, de acordo com a SIMA ${ }^{47}$ e BARROS (2011), a área era utilizada na sua porção mais oeste como depósito de lixo da Companhia Entrepostos e Armazéns Gerais do Estado de São Paulo (CEAGESP), de onde cerca de oitenta famílias recolhiam alimentos e embalagens. Na parte leste, vizinha ao atual Shopping Villa-Lobos, era depositado material dragado do Rio Pinheiros e na porção central o antigo proprietário permitia o depósito de entulho, oriundo da construção civil.

Em paralelo, no início da década de 1980, o arquiteto Decio Tozzi, nos seus caminhos de ida e volta da FAU-USP, passava diariamente por essa área imensa e degradada, que era um dos últimos vazios urbanos do centro expandido de São Paulo (JORNAL DA USP, 2005).

Diante desse cenário diário, o arquiteto teve a ideia de recuperar a área, transformando esse lixão a céu aberto em um parque, para o qual elaborou o projeto. Foi desenhado um parque contemporâneo, com grande e denso bosque biodiversificado, composto por 50 mil árvores divididas em 300 espécies e 12 clareiras gramadas destinadas ao uso livre da população (JORNAL DA USP, 2005).

${ }^{47}$ Secretaria de Infraestrutura e Meio Ambiente do Estado de São Paulo. Parque Villa-Lobos: Histórico. Disponível online em: <https://www.infraestruturameioambiente.sp.gov.br/parquevillalobos/historico/>. Acesso em: 20. Out. 2019. 
No centro, foi projetada uma área balizada por renques de palmeiras imperiais onde foi desenvolvido um paisagismo urbano, composto por uma sucessão de pequenas praças com árvores de sombra, visando representar o paisagismo das praças e jardins urbanos das cidades brasileiras.

Dando continuidade, o arquiteto apresentou o projeto para três vereadores que gostaram da ideia. Posteriormente, por dois anos e meio buscou despertar o interesse da população, divulgando o projeto nas associações de bairro, câmaras comunitárias, escolas, clubes e até em comunidades. Uma vez conquistado o apoio popular, a ideia foi levada ao governo do estado, que se encarregou de desapropriar o terreno.

Em 1987, ano de comemoração do centenário de nascimento de Heitor Villa-Lobos, foram apresentados os primeiros estudos, visando à implantação do parque temático contemporâneo em que tinha a música como principal tema (JORNAL DA USP, 2005).

O projeto executivo foi feito pelo arquiteto e a construção ficou a cargo da Camargo Corrêa, vencedora da licitação. As construções existentes na área do parque foram removidas em 1988.

Com a publicação dos Decretos Estaduais $N^{\circ} 28.335$ de 15 de julho de 1988 e $\mathrm{N}^{\circ}$ 28.336/1988, a área do imóvel passou a ser declarada como utilidade pública para desapropriação, visando à implantação de um "Parque de Lazer, Cultura e Esporte", figura 62 (SÃO PAULO (estado), 1988). Os moradores da região receberam bem a proposta, principalmente por eliminar os problemas causados pela catação dos resíduos.

Figura 62- Placa informativa do governo do Estado de São Paulo sobre a implantação do Parque Estadual VillaLobos.

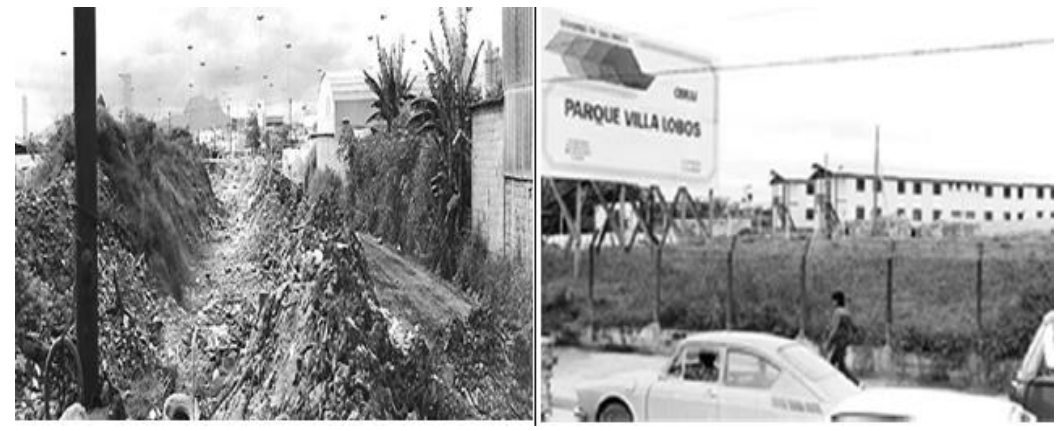

Extraído de: SANCHES, 2011.

Em 1989, o Parque Estadual Villa-Lobos começou a ser implantado (figura 63), iniciando-se pela terraplanagem. 
Figura 63- Implantação do Parque Villa Lobos em 1989.

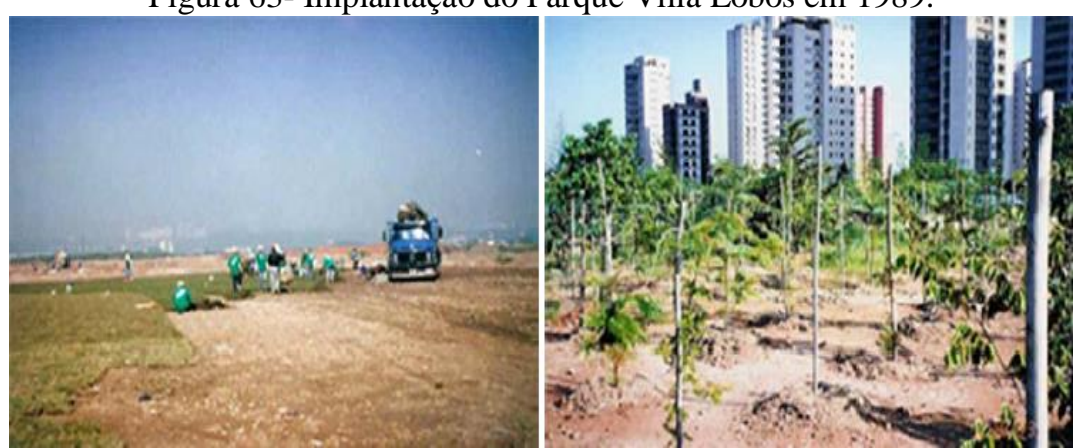

Extraído de: SANCHEZ, 2011; WEBER, 2013.

Toda área do parque recebeu uma cobertura de solo limpo com procedência conhecida, em camadas variáveis para acerto das elevações existentes, impedindo o contato direto com o material depositado e o escoamento da água das chuvas. O córrego Boaçava, que passava pela área, foi canalizado.

Segundo Decio Tozzi, como todo o resíduo foi mantido no terreno, após a terraplanagem o parque ficou 6 metros mais alto que a avenida ao lado dele. Também nesse período foram removidas as famílias que viviam no local, retirados $500 \mathrm{mil} \mathrm{m}^{3}$ de entulho com mais de $1 \mathrm{~m}$ de diâmetro, e movimentados 2 milhões de $\mathrm{m}^{3}$ de entulho.

A etapa seguinte foi converter a superfície degradada e pouco permeável em solo fértil. Para tanto elaborou-se um rigoroso programa de adubações orgânicas usando principalmente húmus do minhocário.

No espaço entre as covas das árvores também foi feita a adubação verde- o plantio de leguminosas de ciclo anual para incorporar ao solo nitrogênio e matéria orgânica. Entretanto, antes que surjam os frutos e sementes, a massa verde é cortada. Por fim, o solo passou por correção com aplicação de calcário e adubos químicos à base de $\mathrm{NPK}^{48}$.

No início de 1990, as árvores começaram a ser plantadas e para organizar a formação dos bosques, o terreno foi dividido em módulos de $10 \mathrm{~m}$ x $10 \mathrm{~m}$ e cada um deles recebeu 25 mudas com intervalo de 2 metros.

As espécies plantadas são distintas entre nativas pioneiras (angico, candeia, embaúba), nativas não pioneiras (cedro, figueira, jatobá), espécies de floração marcante (Ipêamarelo, Ipê-branco, Ipê-roxo) e espécies que atraem pássaros (amoreira, goiaba, coqueirojerivá), totalizando 50 mil árvores e 300 espécies diferentes (TOZZI; GEISER; 2005). 
Em 1994, o parque foi inaugurado inacabado não apresentando o tamanho original proposto com diversas instalações sonoras, prédios de exposições e escolas de balé e música, e a área leste incorporada após dez anos (SANCHES, 2011; WEBER, 2013).

Em janeiro de 2004, a administração do parque foi transferida para a SIMA pelo Decreto Estadual No 48.441/2004. No mesmo ano, foi iniciada a execução de intervenções emergenciais para solucionar problemas de manutenção existentes no local, como adequação da diversidade das espécies.

Também se iniciou a elaboração de projetos executivos para a expansão do parque com base no projeto original. A Resolução SMA No 20, de 7 de março de 2004, criou o Conselho de Orientação do Parque Estadual Villa-Lobos, visando assegurar o gerenciamento participativo e integrado da sociedade civil (SÃO PAULO (estado), 2012).

Para compor esse conselho as entidades da sociedade civil interessadas precisavam fazer seu cadastramento com os dados da instituição. Na época, as instituições cadastradas e que ganharam a eleição passando a representar os interesses da população nas questões relacionadas ao Parque Estadual Villa-Lobos foram: Movimenta Defensa São Paulo, Associação Amigos do Alto de Pinheiros, Sociedade Amigos do Bairro Boaçava e Sócios Fundadores da Sociedade Amigos do Parque Estadual Villa-Lobos.

Essas instituições são organizações não-governamentais ambientalistas atuantes na região e/ou representativas dos moradores do entorno sem fins lucrativos. Elas participaram da criação do parque, da sua implantação e ainda participam do processo de sua conservação e manutenção.

Todos problemas e situações inacabadas que podiam prejudicar a população eram levadas à justiça e até mesmo ao Ministério Público desde 2004, através dessas entidades ambientalistas.

Em 2006, o parque foi entregue concluído com aproximadamente 24 mil árvores plantadas em covas de mil litros de substrato e troca de solo. Foram feitas quadras poliesportivas e de tênis, pista de Cooper, pista para patinadores, anfiteatro, ciclovia campos de futebol e estacionamento com 730 vagas (WEBER, 2013).

Quanto ao entorno, verifica-se uma intensa ocupação residencial, com implantação de condomínios, bem como o Shopping Villa-Lobos, e empreendimentos comerciais como o Hipermercado Carrefour e postos de combustíveis, figura 64. 


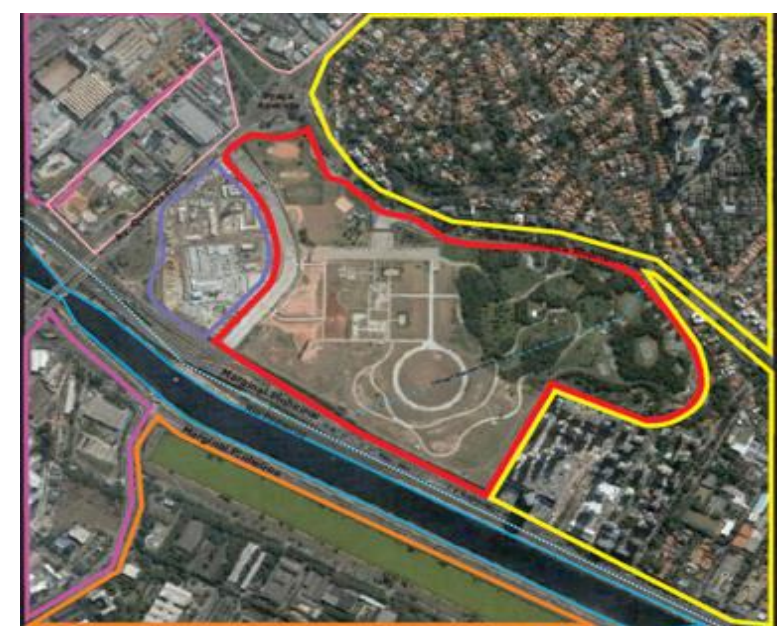

Legenda- Cores: Vermelho- Área do Parque Villa-Lobos; Verde: área verde/loteamento; Azul: Corpo d'água; Amarelo: residências; Lilás: indústrias; Laranja: USP; Rosa: comércio; Roxo: Canteiro de Obra; Traçado: Linha ferroviária-CPTM. Extraído de: WEBER, 2013.

Nesse mesmo ano de 2006, a sociedade civil composta pelas entidades ambientalistas abriu uma a Ação Civil Pública contra o estado com a participação do Ministério Público, a qual terminou em forma de acordo.

A ação questionava muitos pontos do parque como: a demora da abertura de toda a área do Parque Estadual Villa-Lobos à população; a prioridade na implantação dos bosques, espaços gramados, caminhos para pedestres; o interesse da população na ampliação dos espaços de cultura, lazer, esporte e áreas verdes disponíveis; a necessidade de atender e possuir equipamentos para pessoas portadoras de deficiências de locomoção, a restrição para a prática de eventos esportivos ou musicais de grande porte; entre outros (MPSP, 2006).

Diante dessas questões foi estabelecido um acordo entre as partes interessadas Sociedade Civil e Estado com a participação do Ministério Público, deixando claras as atribuições e responsabilidades de cada um quanto ao funcionamento e conservação do Parque Estadual Villa-Lobos.

No ano de 2008 foram plantadas mais 800 mudas referentes ao Termo de Compromisso de Recuperação Ambiental (TCRA) da Autoban, para enriquecimento dos bosques. Dando continuidade ao processo de recuperação da área, em 2009, a SMA recebeu novamente um TCRA da CCR-Autoban, para plantio de 8.404 árvores nativas concluído em abril de 2010. Entre as 8.404 mudas plantadas, 760 são mudas de mais de três metros de altura 
e foram plantadas ao longo das pistas de caminhada e da área central, visando proporcionar mais sombra aos usuários ${ }^{49}$.

Em 2009, foram inaugurados o espaço Villa Ambiental, a nova sede de Administração do parque e uma Sede da $1^{\text {a }}$ Cia. Do $23^{\circ}$ Batalhão da Polícia Militar. Em 2010, foram inaugurados o espaço Ouvillas e o Orquidário da Ruth Cardoso, e em 2013, o centro de educação ambiental (WEBER, 2013).

\subsubsection{Início da Investigação Ambiental}

Dada a dimensão da área e a diversidade de locais e tipos de materiais dispostos, as investigações ambientais começaram a ser realizadas em duas campanhas (07/05/2007 a 15/05/2007 e 24/07/2008 a 01/08/2008), levando-se em conta o tipo de ocupação atual e as vias de exposição. Entre 07/01/2008 e 18/01/2008 foram coletadas novas amostras para confirmação de resultados para ftalatos.

De acordo com as sondagens (de 0 até 15 metros de profundidade) realizadas em todo o parque, foi confirmada a presença de diversos materiais em profundidades diferentes, assim como espessura e tamanhos variados, destacando-se entulhos de construção civil e sedimentos de dragagem do Rio Pinheiros. Entretanto, foi constatada a presença de sacos plásticos, pedaços de louças e vidros, indicando que a área pode ter recebido resíduos de origem doméstica, porém não de forma irregular. Ainda assim, não foi detectada a presença de resíduos de origem industrial.

Os dados analíticos das amostras coletadas indicaram a existência de contaminação no solo subsuperficial e na água subterrânea, apresentados no quadro 15.

Quadro 15- Resultados dos dados analíticos das amostras coletadas.

\begin{tabular}{|c|c|}
\hline $\begin{array}{c}\text { Compartimento Ambiental } \\
\text { afetado }\end{array}$ & Contaminantes identificados \\
\hline Água Subterrânea & Indeno (1,2,3-cd) pireno, chumbo e arsênio \\
\hline $\begin{array}{c}\text { Solo Subsuperficial } \\
\text { Genantreno, PCBs e Bis (2-etilexil) ftalato } \\
\text { Gás Metano }\end{array}$ \\
\hline
\end{tabular}

Extraído de: WEBER, 2013. Elaborado pela autora.

49 Secretaria de Infraestrutura e Meio Ambiente do Estado de São Paulo. Parque Villa-Lobos: Histórico. Disponível online: https://www.infraestruturameioambiente.sp.gov.br/parquevillalobos/historico/. Acesso em: 21 out. 2019. 
Durante a realização das sondagens de vapores no solo, observou-se um fluxo ascendente de gás sob pressão em um dos pontos investigados na área dos prédios da administração, com concentrações superiores a 10.000 ppm ou 100\% LIE. O monitoramento apontou a presença unicamente de gás metano, gerado a partir da degradação da matéria orgânica.

Perante essa confirmação, foi realizado o monitoramento da presença de gases em todas utilidades subterrâneas (galerias de águas pluviais, caixas de passagem, galeria de drenagem), que não evidenciou valores significativos de riscos de explosividade pela equipe técnica de emergências da CETESB. Quanto aos cenários de exposição no parque, foi considerado:

- Cenário: área atual do parque, em que houve a disposição de resíduos.

- Receptores: trabalhadores de obras civis ou de escavações/movimentações do solo; usuários e funcionários; residentes e comerciantes vizinhos.

- Via de exposição: Contato dérmico com solo e inalação de partículas em ambientes abertos e fechados.

Não se caracterizou na área e no seu entorno a exposição da ingestão de água subterrânea do aquífero livre, em função dos poços levantados estarem instalados em porções mais profundas. Porém, observou-se a existência de cisternas e outros pontos de acúmulo de águas pluviais utilizadas para a irrigação, caracterizando-se as vias de exposição de contato dérmico e inalação de vapores de água para os usuários e funcionários do parque, em ambientes abertos e fechados.

Diante dos resultados, o estudo indicou a adoção das seguintes medidas mitigadoras para a área, descrita no quadro 16.

Quadro 16- Medidas mitigadoras para a área do Parque Estadual Villa-Lobos.

\begin{tabular}{l} 
Medidas Mitigadoras \\
$\begin{array}{l}\text { Não permitir quaisquer atividades de escavação ou movimentação de solo, exceto sob a } \\
\text { supervisão de equipe técnica capacitada utilizando EPIs, bem como, isolamento dos } \\
\text { usuários do parque. }\end{array}$ \\
\hline $\begin{array}{l}\text { Não explotar e/ou utilizar água subterrânea do aquífero raso do local para nenhuma } \\
\text { finalidade em toda área do parque. }\end{array}$ \\
\hline $\begin{array}{l}\text { Se houver a necessidade de remoção de parte do solo subsuperficial do local, deve ser } \\
\text { providenciada a sua caracterização e adoção de medidas cabíveis. }\end{array}$ \\
Extraído de: WEBER, 2013. Elaborado pela autora.
\end{tabular}


Foi também relatado a necessidade de uma investigação mais detalhada para vapores no solo, com a finalidade de definir sua extensão e a implantação de medidas de intervenção, principalmente nos locais onde existe a possibilidade de acúmulo de ambientes confinados.

Em complemento à investigação confirmatória, em abril e junho de 2009, foi realizado uma investigação da água subterrânea na área externa do parque, entre sua divisa e a Marginal Tietê.

Os resultados das análises das amostras de água subterrânea demonstraram que apenas o zinco excedeu o valor de intervenção (VI) estabelecidos pela CETESB (2005). Verificou-se que apesar do contaminante zinco ter excedido o VI, de acordo com a avaliação de risco o valor encontrado na época, estava abaixo da concentração que representa risco para o cenário residencial de ingestão para trabalhadores e usuários do futuro parque (consumo de 2 litros/dia).

Desta forma, foi recomendado a não utilização da água subterrânea local e o monitoramento com periocidade semestral, ao menos até a finalização da investigação da área. Também foi demonstrado não haver contaminação significativa na água subterrânea com origem na área do Parque Estadual Villa-Lobos.

\subsubsection{Estudos Ambientais Complementares}

Em função da contaminação identificada e dando sequência ao gerenciamento ambiental na área do Parque Estadual Villa-Lobos, em novembro de 2012, foram definidas trinta áreas para amostragem de solo superficial juntamente com a administração do Parque.

Para água subterrânea foram instalados vinte e nove poços de monitoramento (figura 65) e para monitoramento de gás cinquenta e nove para ambientes abertos e vinte áreas para ambientes fechados, uma vez que tem poucos ambientes confinados.

Uma informação importante que cabe destacar é que a própria administração do parque foi relatar que era feito periodicamente o recobrimento de solo, alertando-se para o fato de que o solo superficial que seria analisado não se trataria de solo da época de aterramento da área, e sim, solo de recobrimento. 
Figura 65-Poços de Monitoramento de água instalado no Parque Estadual Villa-Lobos.

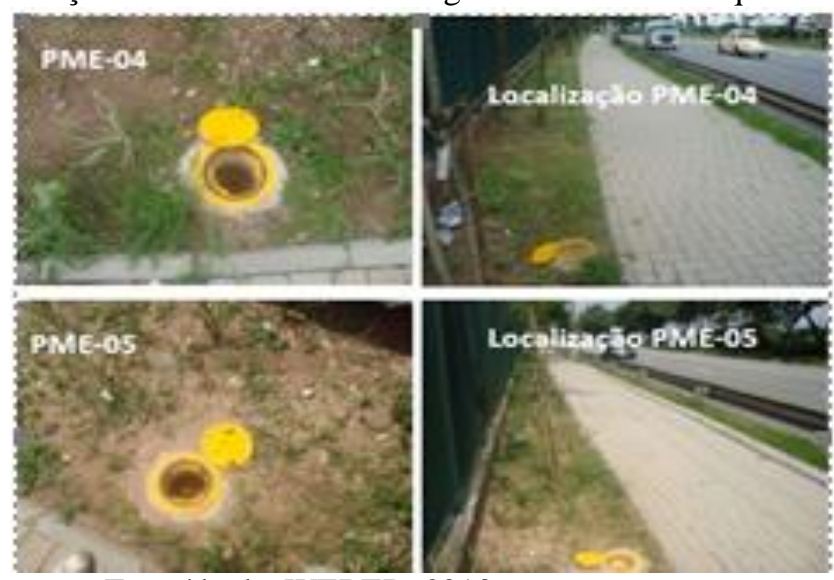

Extraído de: WEBER, 2013.

De acordo com os resultados obtidos das sondagens, os resíduos identificados foram classificados como resíduos não perigosos e inertes, sendo permitida a sua utilização pelo próprio parque.

Verificou-se ainda a extensa presença de material dragado do Rio Pinheiros, caracterizado por argila arenosa, cinza claro à escura com odor e entulhos, depositados em diversas porções do parque. O quadro 17 apresenta os resultados das análises detectadas dos compostos Semi-Voláteis presentes no solo e na água subterrânea.

Quadro 17- Resultados das amostras coletadas para Compostos Semi-Voláteis.
\begin{tabular}{|c|l|}
\hline $\begin{array}{c}\text { Compartimento } \\
\text { Ambiental afetado }\end{array}$ & \multicolumn{1}{|c|}{ Contaminantes identificados } \\
\hline Água Subterrânea & $\begin{array}{l}\text { Metais (bário, boro, chumbo, manganês, níquel e } \\
\text { selênio) e Compostos Orgânicos Voláteis } \\
\text { (bromodiclorometano). }\end{array}$ \\
\hline Solo & $\begin{array}{l}\text { Diversos pontos para ftalato e PAHS } \\
\text { (Hidrocarbonetos Policíclicos Aromáticos), } \\
\text { sendo: dietilexil ftalato, benzo (b)fluoranteno e } \\
\text { benzo(k)fluoranteno. } \\
\text { Metais dissolvidos e totais (cobalto e níquel). }\end{array}$ \\
\hline
\end{tabular}

Extraído de: WEBER, 2013. Elaborado pela autora.

Para o gás metano considerou-se o uso residencial, avaliando-se o uso do parque pelos funcionários e usuários. Foram detectadas concentrações nos poços de monitoramento amostrados variando de 52.300ppm (5,23\%) a 983.000ppm (98.3\%), concentrações essas acima da faixa de inflamabilidade do composto, que é de 5\% a 15\% (WEBER, 2013). No entanto, nos ambientes fechados monitorados não foram encontradas concentrações superiores a $217 \mathrm{ppm}(0,21 \%)$. 
O modelo conceitual para a avaliação de risco foi baseado principalmente nos resultados da avaliação detalhada. Foram considerados os seguintes modelamentos em dois momentos:

\section{- Cenário Real}

Receptores: Usuários do parque, funcionários do parque, trabalhadores no entorno e moradores no entorno;

Vias de exposição: Inalação de partículas de solo superficial, contato dérmico com solo superficial, ingestão de partículas de solo superficial, ingestão de vegetais, inalação de vapores de solo subsuperficial e da água subterrânea em ambientes abertos e fechados.

- Cenário Hipotético

Receptores: Usuários do parque, funcionários do parque, trabalhadores no entorno e moradores no entorno e trabalhadores de obra civil;

Vias de Exposição: contato dérmico com a água subterrânea, ingestão de água subterrânea, contato dérmico com o solo subsuperficial e ingestão de lixiviado do solo subsuperficial na água subterrânea.

No quadro 18, está apresentado o resultado da avaliação de risco calculado identificando os principais cenários, vias de exposição e receptores nas áreas de interesse.

Nos poços de monitoramento de gases foram detectadas concentrações acima do VI para benzeno e etilbenzeno nos poços situados ao lado das construções, que possuem ambientes subterrâneos, sendo o Orquidário e Centro de Referência em Educação Ambiental, como mostrado na figura 66.

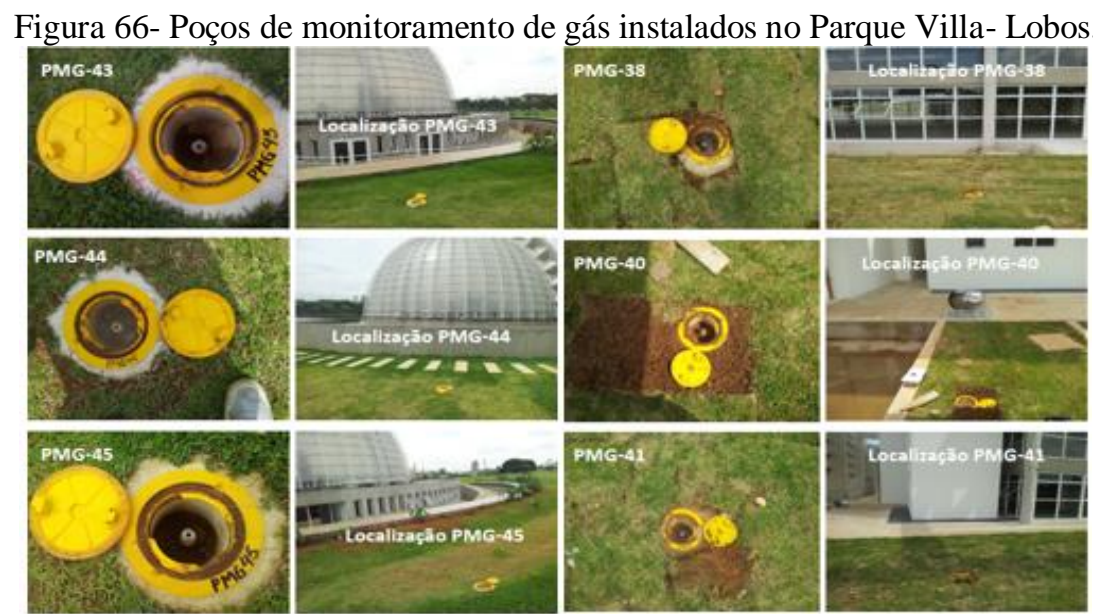

Extraído de: WEBER, 2013. 
Quadro 18-Riscos calculados e identificados à saúde humana em diferentes cenários, no ano de 2012.

\begin{tabular}{|c|c|c|c|c|c|c|c|}
\hline Cenários & \multicolumn{4}{|c|}{ Receptores } & \multirow{2}{*}{$\begin{array}{c}\begin{array}{c}\text { Vias de Exposição/ } \\
\text { Compartimento } \\
\text { Ambiental }\end{array} \\
\text { Inalação } \\
\text { Ingestão } \\
\text { Contato Dérmico }\end{array}$} & \multirow{2}{*}{$\begin{array}{c}\text { Risco } \\
\text { Toxicológico }\end{array}$} & \multirow{2}{*}{$\begin{array}{c}\text { Efeitos } \\
\\
\text { Carcinogênico (C) } \\
\text { Ou } \\
\text { Não Carcinogênico } \\
\text { (NC) }\end{array}$} \\
\hline \multirow{4}{*}{$\mathrm{Na}$ fonte } & $\begin{array}{c}\text { Crianças } \\
6 \text { anos de exposição } \\
24 \text { horas/dia } \\
350 \text { dias/ano }\end{array}$ & $\begin{array}{c}\text { Adultos } \\
30 \text { anos de exposição } \\
24 \text { horas/dia } \\
350 \text { dias/ano }\end{array}$ & $\begin{array}{c}\text { Comercial/Industrial } \\
\text { 25anos de exposição } \\
\text { 8horas/dia } \\
290 \text { dias/ano }\end{array}$ & $\begin{array}{c}\text { Trabalhador Civil } \\
2 \text { anos de exposição } \\
8 \text { horas/ dia } \\
290 \text { dias /anos }\end{array}$ & & & \\
\hline & risco & --- & --- & --- & $\begin{array}{l}\text { Ingestão de partículas de } \\
\text { solo superficial }\end{array}$ & Cobalto e Níquel & $\mathrm{NC}$ \\
\hline & risco & --- & --- & --- & $\begin{array}{c}\text { Ingestão de água } \\
\text { subterrânea solo a partir da } \\
\text { lixiviação }\end{array}$ & Níquel & $\mathrm{NC}$ \\
\hline & risco & risco & risco & risco & $\begin{array}{l}\text { Ingestão de água } \\
\text { subterrânea }\end{array}$ & $\begin{array}{c}\text { Bário, Cobalto e } \\
\text { Manganês }\end{array}$ & $\mathrm{NC}$ \\
\hline \multirow[t]{2}{*}{$\begin{array}{l}\text { Fora da fonte } \\
\qquad(10 \mathrm{~m})\end{array}$} & risco & --- & --- & $* \mathrm{NA}$ & $\begin{array}{l}\text { Ingestão de água } \\
\text { subterrânea a partir da } \\
\text { lixiviação do solo }\end{array}$ & Níquel & $\mathrm{NC}$ \\
\hline & risco & risco & risco & NA & $\begin{array}{l}\text { Ingestão de água } \\
\text { subterrânea }\end{array}$ & $\begin{array}{l}\text { Cobalto e } \\
\text { Manganês }\end{array}$ & $\mathrm{NC}$ \\
\hline \multirow[t]{2}{*}{$\begin{array}{l}\text { Fora da fonte } \\
\qquad(25 \mathrm{~m})\end{array}$} & risco & --- & --- & NA & $\begin{array}{c}\text { Ingestão de água } \\
\text { subterrânea a partir da } \\
\text { lixiviação do solo }\end{array}$ & Níquel & $\mathrm{NC}$ \\
\hline & risco & risco & --- & NA & $\begin{array}{l}\text { Ingestão de água } \\
\text { subterrânea }\end{array}$ & $\begin{array}{l}\text { Cobalto e } \\
\text { Manganês }\end{array}$ & $\mathrm{NC}$ \\
\hline $\begin{array}{l}\text { Fora da fonte } \\
\quad(50 \mathrm{~m})\end{array}$ & risco & --- & --- & NA & $\begin{array}{l}\text { Ingestão de água } \\
\text { subterrânea }\end{array}$ & & $\mathrm{NC}$ \\
\hline
\end{tabular}

Legenda: *NA: Não aplicável. Extraído de: WEBER, 2013. Elaborado pela autora. 
É importante destacar que os riscos associados à saúde humana para os compostos orgânicos voláteis caracterizam-se pela exposição a longo prazo com características carcinogênicas e toxicológicas.

Quanto ao metano foram detectadas altas concentrações em todos poços de monitoramento, ultrapassando inclusive a faixa de inflamabilidade desse composto. Desta forma, seu risco está associado à explosividade. Foram propostas as seguintes medidas de intervenção para a área, quadro 19:

Quadro 19-Medidas de Intervenção para Parque Estadual Villa-Lobos.

\begin{tabular}{|c|}
\hline o de solo e outras obras rela \\
\hline \\
\hline $\begin{array}{l}\text { a do } \\
\text { que } \\
\text { uma } \\
\text { dos }\end{array}$ \\
\hline $\begin{array}{l}\text { ventilação que } \\
\text { solo. } \\
\text { rio promover a } \\
\text { orma avaliar a } \\
\text { suas utilidades } \\
\text { com o solo; }\end{array}$ \\
\hline
\end{tabular}

Extraído de: WEBER, 2013. Elaborado pela autora. 


\subsubsection{Situação Ambiental atual da área}

Segundo o SIMA $(2020)^{50}$, o Parque Estadual Villa-Lobos abrange uma área de 732 mil $\mathrm{m}^{2}$ e possui ciclovia, quadras, campos de futebol, playground e bosque com espécies de Mata Atlântica, figura 67.

A área de lazer inclui ainda aparelhos para ginástica, pista de Cooper, basquete e um anfiteatro aberto com 750 lugares, sanitários adaptados para deficientes físicos e lanchonetes.

Estima-se que durante a semana cerca de 8 mil pessoas passem a cada dia pelo parque e aos finais de semana recebe cerca de 50 mil visitantes e aos feriados 60 mil.

Figura 67- Área de recreação- Parque Villa Lobos.

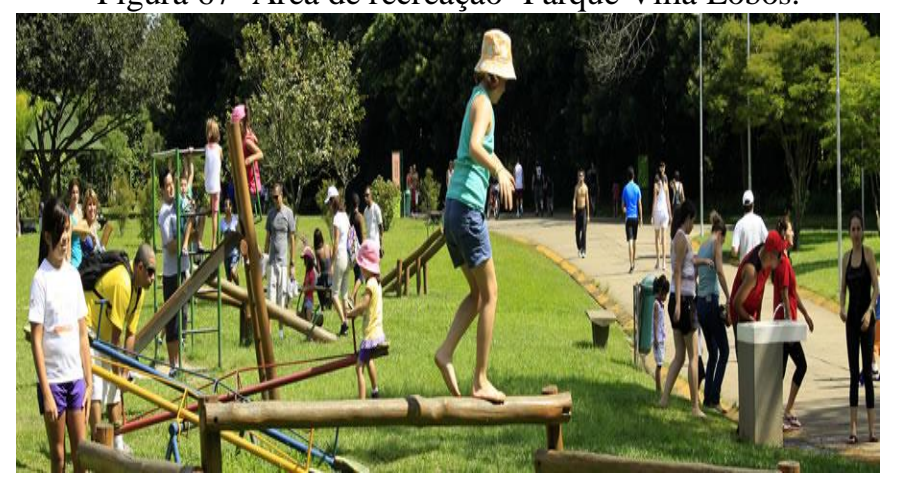

Extraído de: <https://www.infraestruturameioambiente.sp.gov.br/parquevillalobos>. Acesso em: 05 jan. 2020.

O parque é abastecido por rede de água e esgoto da SABESP, e ainda possui poços profundos de captação de água subterrânea para fins de irrigação. Além disso, possui poucos ambientes confinados, ou seja, sem ventilação.

Os banheiros, em sua maioria são instalados com parede vazada na parte superior. $\mathrm{Na}$ Villa Ambiental apresenta paredes e tetos não contínuos, há um vão entre eles, permitindo a ventilação. As áreas administrativas apresentam janelas (WEBER, 2013).

No Centro de Referência em Educação Ambiental, observa-se um auditório em subsuperfície, sem a presença de janelas e no orquidário janelas de apoio e na porção central há ventilação para manutenção das plantas.

\footnotetext{
${ }^{50}$ Secretaria de Infraestrutura e Meio Ambiente: o parque. Disponível em: https://www.infraestruturameioambiente.sp.gov.br/parquevillalobos/o-parque/. Acesso em: 05 jan. 2020.
} 


\subsubsection{Atrativos no Parque Estadual Villa-Lobos}

De acordo com as informações contidas na página institucional do parque, o mesmo conta com diversos atrativos, apresentados no quadro 20.

Quadro 20- Atrativos no Parque Estadual Villa-Lobos.

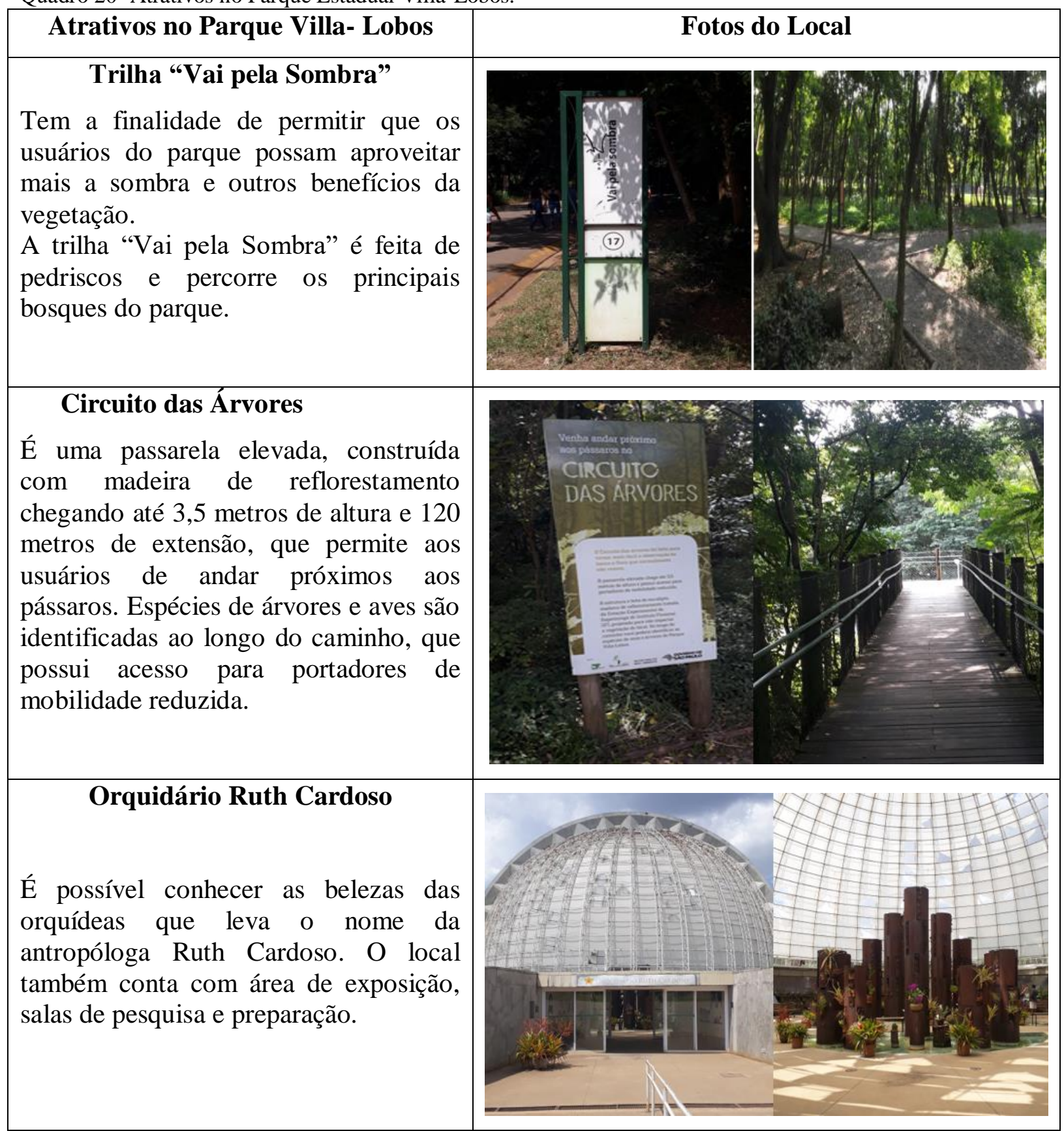

Continua... 


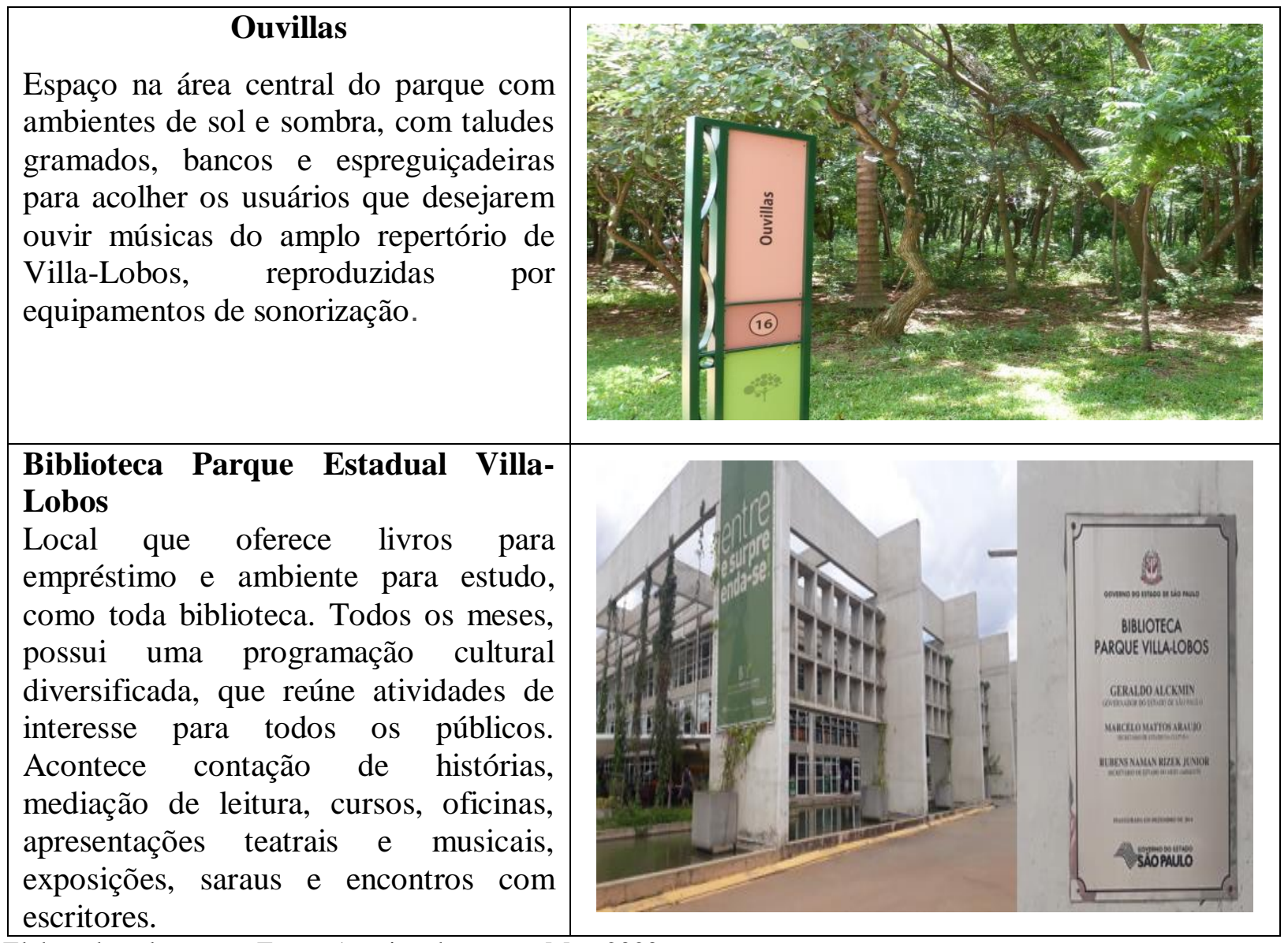

Elaborado pela autora. Fotos: Arquivo da autora. Mar. 2020

\subsubsection{Atores envolvidos no caso}

O processo de requalificação do Parque Estadual Villa-Lobos iniciou-se pelo interesse do arquiteto Decio Tozzi em recuperar a área. Posteriormente, buscou-se o apoio do poder público e da sociedade civil para a aprovação do projeto.

Com base no histórico e ações ocorridas na área, os principais stakeholders envolvidos para que ocorresse a requalificação da área em parque público foram: a sociedade civil (população e as entidades não governamentais- ONGs da região e do entorno do parque); o setor privado (Construtora Camargo Corrêa S.A e) contratada para realizar a construção do parque e a empresa especializada em paisagismo (Rodolfo Geiser e Christiane Ribeiro Paisagismo e Meio Ambiente) para projetar a reabilitação da área, o manejo da vegetação e a criação de bosques; e o setor público (Governo do estado e o Ministério Público). 


\subsubsection{Observações Gerais sobre o estudo de Caso 2}

A área contaminada do Parque Estadual Villa-Lobos foi requalificada com êxito em parque público como pretendido pelo governo do estado, em função de que:

1. O projeto elaborado despertou o interesse dos atores envolvidos (estado e sociedade civil);

2. Houve a cooperação e transparência dos atores envolvidos em cada tomada de decisão, sem conflitos, visando um objetivo em comum;

3. A elaboração do projeto foi executada por um profissional com experiência em grandes projetos de arquitetura e urbanismo;

4. Por meio de licitação, houve o interesse de construtoras na obra ficando responsável pela construção do parque;

5. O paisagismo realizado foi feito por uma empresa especializada com experiência na área;

6. Apresentou todas as medidas restritivas que devem ser realizadas durante a implantação e a futura ocupação da área;

7. Restringiu o uso e a captação da água subterrânea do aquífero raso local para nenhuma finalidade em toda área do parque;

8. Cumpriu todo o procedimento do gerenciamento ambiental estabelecido para a área, seguindo as legislações vigentes e as instruções da CETESB, uma vez que as ações foram realizadas anteriormente à publicação da DD N³8/2017/C;

9. No contexto brasileiro, é considerado um caso de sucesso de requalificação de área contaminada convertida em área verde e de lazer na cidade de São Paulo.

No quadro 21 está apresentado todo o histórico e as ações realizadas no Parque Municipal Jardim Primavera até a paralisação das obras, assim como no Parque Estadual Villa-Lobos até sua conclusão. 
Quadro 21- Histórico e ações realizadas nas áreas dos estudos de caso.

\begin{tabular}{|c|c|c|c|c|c|}
\hline Parque & Ano & Situação & Parque & Ano & Situação \\
\hline \multirow{15}{*}{$\begin{array}{c}\text { Jardim } \\
\text { Primavera }\end{array}$} & 1950 & Área livre de ocupação & \multirow{15}{*}{ Villa-Lobos } & 1950 & Área livre de ocupação \\
\hline & 1968 & Início da mineração de areia & & 1958 & $\begin{array}{c}\text { Início da ocupação, vegetação rasteira, movimentos de terra } \\
\text { Córrego Boaçava atravessava a área }\end{array}$ \\
\hline & \multirow[t]{2}{*}{$\begin{array}{l}1979 \\
1979\end{array}$} & \multirow[t]{2}{*}{$\begin{array}{c}\text { Início do Lixão } \\
\text { Encerramento da mineração de areia }\end{array}$} & & 1968 & $\begin{array}{c}\text { Movimento de terra em valas } \\
\text { Estradas utilizadas para extração de areia }\end{array}$ \\
\hline & & & & 1974 & $\begin{array}{l}\text { Disposição de material dragado trecho sul da área } \\
\text { Recomposição vegetal em uma cava } \\
\text { Novo movimento de terra, porção nordeste }\end{array}$ \\
\hline & \multirow[t]{2}{*}{$\begin{array}{l}1981 \\
1981\end{array}$} & \multirow[t]{2}{*}{$\begin{array}{l}\text { Reclamação da população à Subprefeitura } \\
\text { Aterramento da cava menor }\end{array}$} & & 1977 & $\begin{array}{l}\text { Cava aterrada porção noroeste } \\
\text { Retirado balsas com material dragado }\end{array}$ \\
\hline & & & & 1980 & $\begin{array}{l}\text { Arquiteto Decio Tozzi identifica área degradada } \\
\text { Elaboração do projeto para sua recuperação }\end{array}$ \\
\hline & \multirow[t]{2}{*}{1983} & \multirow{2}{*}{$\begin{array}{c}\text { Elaboração do projeto Aterro Sanitário Jacuí } \\
\text { Transformação em Aterro Controlado } \\
\text { Instalação dos Drenos }\end{array}$} & & 1986 & $\begin{array}{l}\text { Aparecimento de novos caminhos formados dentro da área } \\
\text { Ocupação residencial com campo de futebol. }\end{array}$ \\
\hline & & & & 1986 & $\begin{array}{c}\text { Porção Oeste- resíduo da CEAGESP } \\
\text { Porção leste- material dragado do Rio Pinheiros } \\
\text { Porção central- depósito de resíduo de construção civil }\end{array}$ \\
\hline & 1988 & $\begin{array}{l}\text { CETESB Tatuapé Acionada- Acidente em residência } \\
\text { Encerramento do Aterro Controlado }\end{array}$ & & 1987 & Projeto Parque Temático Contemporâneo \\
\hline & 1990 & Projeto Piloto do Parque- SVMA/DEPAVE & & \multirow[t]{2}{*}{1988} & \multirow{2}{*}{$\begin{array}{c}\text { Licitação Camargo Correia- Responsável pela construção do } \\
\text { parque }\end{array}$} \\
\hline & 1991-1992 & $\begin{array}{l}\text { Início da construção do Parque } \\
\text { Recomposição Vegetal } \\
\text { Paralisação das obras }\end{array}$ & & & \\
\hline & 1994-1998 & $\begin{array}{l}\text { Migração de gás para residências } \\
\text { Inspeções Técnicas da CETESB }\end{array}$ & & 1989 & $\begin{array}{c}\text { Início da implantação do Parque Estadual Villa-Lobos } \\
\text { Córrego Boaçava canalizado } \\
\text { Remoção das famílias que viviam no local }\end{array}$ \\
\hline & 1995 & Plantio Eucaliptal pela SVMA & & 1990 & Plantio Arbóreo- 50 mil árvores/ 300 espécies \\
\hline & 2001 & $\begin{array}{l}\text { Constatação significativa de gás- COMGÁS } \\
\text { Funcionamento inadequado dos drenos }\end{array}$ & & 1994 & $\begin{array}{l}\text { Parque construído de forma parcial diferente do projeto } \\
\text { original }\end{array}$ \\
\hline & 2002 & Lei 13.302- Cria o Parque Muncipal Jardim Primavera & & 2004 & $\begin{array}{l}\text { Transferência da administração do parque para SIMA Decreto } \\
\text { Estadual No } 48.441 / 2004 \\
\text { Problemas de manutenção no local- adequação da diversidade } \\
\text { das espécies } \\
\text { Elaboração de projetos executivos para a expansão do parque }\end{array}$ \\
\hline
\end{tabular}




\begin{tabular}{|c|c|c|c|}
\hline \multirow{2}{*}{\begin{tabular}{|l|l|} 
& \\
\cline { 2 - 2 } & 2004 \\
\end{tabular}} & & & $\begin{array}{l}\text { Resolução SMA No 20, de } 7 \text { de março de 2004- cria o } \\
\text { Conselho de Orientação do Parque Estadual Villa-Lobos }\end{array}$ \\
\hline & CETESB solicita estudo detalhado na área & 2006 & $\begin{array}{c}\text { Parque concluído com } 24 \text { mil árvores plantadas } \\
\text { Entidades ambientalistas- Ação Civil Pública contra o Estado } \\
\text { com a participação do Ministério Público }\end{array}$ \\
\hline $2007-2008$ & Avaliação Preliminar e Confirmatória & $2007-2008$ & Avaliação Preliminar e Confirmatória \\
\hline 2008 & $\begin{array}{l}\text { Retomada da implantação do parque- Fase I } \\
\text { Paralisação das obras }\end{array}$ & 2008 & Plantio de mais 800 mudas na área \\
\hline 2010 & Retomada das obras- Fase I & 2009 & $\begin{array}{c}\text { Avaliação Confirmatória- Área externa, entorno do parque e } \\
\text { Marginal Tietê }\end{array}$ \\
\hline 2011 & $\begin{array}{c}\text { Finalização das obras- Fase I } \\
\text { Elaboração Termo de Referência- Fase II }\end{array}$ & 2009 & $\begin{array}{c}\text { Parque recebeu } 8.404 \text { mudas nativas } \\
\text { Inauguração dos espaços: Villa Ambiental, Administração e } \\
\text { Sede da Polícia Militar e Samu }\end{array}$ \\
\hline 2012 & $\begin{array}{c}\text { Contratação de Serviços- Instalaçãa Sistema de extração } \\
\text { de Vapores- Inviabilidade Econômica }\end{array}$ & 2010 & Espaços Inaugurados: Ouvillas, Orquidário Ruth Cardoso \\
\hline 2012 & Interdição da área- Ministério Público & 2012 & $\begin{array}{c}\text { Avaliação Detalhada, Avaliação de Risco e Plano de } \\
\text { Intervenção }\end{array}$ \\
\hline 2013 & Proposto pela SVMA- Monitoramento dos gases & 2013 & Centro de Educação Ambiental- Biblioteca Villa Lobos \\
\hline $2014-2016$ & $\begin{array}{l}\text { Avaliação detalhada, Avaliação de Risco e Plano de } \\
\text { Intervenção } \\
\text { Monitoramento de Gases na área- Metano e VOCs }\end{array}$ & 2020 & $\begin{array}{l}\text { Parque concluído considerado caso de sucesso no Brasil, em } \\
\text { específico no município de São Paulo. }\end{array}$ \\
\hline Fev/2017 & $\begin{array}{l}\text { SVMA solicitou a CETESB a emissão do Termo de } \\
\text { Reabilitação de Área para Uso Declarado (AR). }\end{array}$ & & \\
\hline Maio/2017 & $\begin{array}{c}\text { CETESB aprovou o plano de intervenção para } \\
\text { reutilização da área. } \\
\text { Parecer Técnico favorável para a reabertura de forma } \\
\text { parcial da Fase I do Parque. }\end{array}$ & & \\
\hline Dez/2018 & $\begin{array}{l}\text { Vistoria da Perícia do Ministério Público na área para } \\
\text { avaliação. }\end{array}$ & & \\
\hline 2020 & $\begin{array}{l}32 \text { anos após o fechamento do aterro controlado, e não } \\
\text { ocorreu a finalização parque para benefício da } \\
\text { população. }\end{array}$ & & \\
\hline
\end{tabular}

Extraído de: referências citadas no trabalho. Elaborado pela autora. 


\section{DISCUSSÃO E COMPARAÇÃO DOS ESTUDOS DE CASO}

\subsection{MUNICÍPIO E ESTADO DE SÃO PAULO}

Nos dias atuais, a presença de áreas contaminadas nas grandes cidades representa um grande desafio para o desenvolvimento urbano sustentável.

Por meio da implantação da gestão e o aprimoramento da publicação anual da listagem do Relatório de Áreas Contaminadas e Reabilitadas no Estado de São Paulo da CETESB, é possível observar a evolução crescente do número de áreas contaminadas identificadas que vem sendo registrado e divulgado oficialmente.

Em maio de 2002, a CETESB, pela primeira vez, publicou a listagem de áreas contaminadas apresentando na época, 255 áreas (SPÍNOLA et al. 2014). Segundo o último levantamento, feito em dezembro de 2019, o número passou para 6.285 sendo 2.302 áreas localizadas no município de São Paulo, apresentado na tabela 1.

Tabela 1- Número de áreas contaminadas cadastradas no estado e no município de São Paulo, até 2019.

\begin{tabular}{ccccc}
\hline Fonte Poluidora & Estado & \multicolumn{2}{c}{ Município } \\
& $\mathrm{N}^{\mathbf{o}}$ & $\%$ & $\mathrm{~N}^{\mathbf{0}}$ & $\%$ \\
\hline Indústria & 1220 & 20 & 135 & 6 \\
Comércio & 328 & 5 & 450 & 19 \\
Posto de Combustível & 4475 & 71 & 1643 & 71 \\
Resíduo & 207 & 3 & 60 & 3 \\
Acidente/Desconhecida/Agricul.* & 55 & 1 & 14 & 1 \\
\hline TOTAL & 6.285 & 100 & 2302 & 100 \\
\hline
\end{tabular}

Legenda: Agricultura*. Extraído de: CETESB, 2019. Elaborado pela autora.

Com base nos usos anteriores das áreas, percebe-se que há uma variedade nas fontes poluidoras que causaram a contaminação como passivo ambiental nesses locais, estando sujeitos a problemas futuros relacionados ao meio ambiente e à saúde humana.

Considerando o número de áreas contaminadas presentes no município até no ano de 2019, nota-se que os postos de combustíveis se destacam, com 1643 locais, representando $71 \%$ das áreas. Essa atividade apresenta-se também como a primeira fonte poluidora no estado, de grande impacto no território urbano.

Esse registro identificado, se deve ao resultado do desenvolvimento do programa de licenciamento ambiental conduzido pela CETESB desde o ano 2000, e a publicação da Resolução Conama $N^{\circ} 273$, de 29 de novembro de 2000, regulamentada no estado de São Paulo pela Resolução da SMA N5, de 28 de março de 2001 (BRASIL, 2000; SÃO PAULO 
(estado), 2001). A partir dessa legislação, a CETESB passou a estabelecer normas e procedimentos técnicos, administrativos e financeiros voltados para a fiscalização e licenciamento ambiental dos postos revendedores de combustíveis, postos de abastecimento de combustíveis, das instalações de sistemas retalhistas de combustíveis e dos postos flutuantes de combustíveis, visando o controle preventivo e corretivo dessas fontes poluidoras no estado (SÃO PAULO (estado), 2001).

Conforme VALETIM (2005) destaca, mais de 2/3 das contaminações são oriundas de postos de combustíveis, e a preocupação é grande, em consequência dos vazamentos e operações de armazenamento de petróleo e seus derivados. Além disso, o autor enfatiza que, do ponto de vista da saúde pública, é de grande significância, pois podem expor a população a substâncias tóxicas nelas presente, assim como atingir as águas subterrâneas.

É importante enfatizar que, dependendo da quantidade estocada em cada tanque, uma vez derramada ao solo, pode inviabilizar o consumo de milhões de $\mathrm{m}^{3}$ de água, atingindo diretamente a fonte de abastecimento para consumo humano.

Seguindo as fontes de contaminação identificadas e comparando-as, os setores industrial e comercial, quando somados totalizam 585 áreas, correspondendo $25 \%$ de locais contaminados no município. Essas atividades caracterizam-se como a segunda fonte poluidora mais presente no território urbano, que se devem à ausência de procedimentos seguros quanto aos seus processos produtivos.

GÜNTHER (2002) relata que muitas vezes o manejo de substâncias perigosas emprega ou produz produtos que acabam gerando um grande volume e uma diversidade de contaminantes no solo e nas águas subterrâneas. Além disso, com o crescimento industrial intensivo e suas transformações ocorridas na cidade na década de 1970, e mais o processo de desindustrialização em 1980, acarretaram em muitos locais industriais abandonados e desativados (GÜNTHER, 2006), que, de acordo com CUNHA (1997), se configuram como áreas de contaminação críticas, uma vez que sobre elas não se exercia qualquer forma de controle ambiental e restrições de reutilização.

SANCHEZ (2001) destaca que outros fatores também contribuíram para a desativação de indústrias, como: o avanço da legislação ambiental cada vez mais rigorosa e restritiva; o lançamento direto de dejetos nos corpos d'água; a emissão de poluentes e ruídos; a necessidade de espaço físico para a expansão; o alto custo da terra urbana em regiões centralizadas e as taxas e impostos altos. 
Após o setor industrial, a terceira fonte de poluição mais frequente é pela disposição de resíduos sólidos, objeto desse estudo. Há 60 locais contaminados por disposição de resíduos sólidos urbanos, correspondendo a 3\% do total de áreas contaminadas. No município de São Paulo, pode se dizer que a maioria desses locais foi utilizada como lixões, sem nenhuma forma de controle ambiental e sanitária, e que hoje se configura como locais com grande potencial para reutilização dentro da malha urbana. E por fim, têm-se as áreas contaminadas de maneira acidental, desconhecida ou pela agricultura com respectivamente 14 áreas contaminadas, representando $1 \%$ no município.

Pelo relatório da Cetesb, é possível identificar quais são as áreas que estão sob medidas de intervenção; em monitoramento; em processo de reutilização e as áreas já reabilitadas, conforme apresentado na tabela 2.

Tabela 2- Situação ambiental das áreas cadastradas no estado e munícipio de São Paulo, até dez/2019.

\begin{tabular}{lcccc}
\hline Classificação da Área & \multicolumn{2}{c}{ Estado } & \multicolumn{2}{c}{ Município } \\
& $\mathrm{N}^{\mathbf{0}}$ & $\%$ & $\mathrm{~N}^{\mathbf{0}}$ & $\%$ \\
\hline $\mathrm{ACRi}$ & 828 & 13,17 & 448 & 13,18 \\
$\mathrm{ACRu}$ & 226 & 3,60 & 195 & 5,74 \\
$\mathrm{ACI}$ & 652 & 10,37 & 280 & 8,24 \\
$\mathrm{AME}$ & 1375 & 21,88 & 650 & 19,13 \\
$\mathrm{ACRe}$ & 1429 & 22,74 & 704 & 20,72 \\
AR & 1775 & 28,24 & 1121 & 32,99 \\
\hline TOTAL & 6285 & 100 & 3398 & 100 \\
\hline
\end{tabular}

Legenda: Área Contaminada com Risco Confirmado (ACRi); Área Contaminada em Processo de Reutilização (ACRu); Área Contaminada sob Investigação (ACI); Área em processo de Monitoramento para Encerramento (AME); Área Contaminada em processo de Remediação; Área Reabilitada para o Uso Declarado (AR). Extraído de: CETESB, 2019. Elaborado pela autora.

No Estado quando somadas as áreas em processo de monitoramento para encerramento (AME) 1375 e as áreas reabilitadas para uso declarado (AR) 1775, representam $50 \%$ das áreas já em situações seguras para o processo de reutilização, em novos usos e funções, ou seja, em condições aptas para uso declarado. No Município, observa-se um percentual maior de 52\%, com respectivamente 1771 áreas aptas, mostrando uma grande atração para o mercado imobiliário, sempre em busca para construções de empreendimentos residenciais, comerciais e serviços.

Entretanto, em decorrência da escassez de terras urbanas disponíveis face à demanda pelo setor imobiliário, da disponibilidade reduzida de áreas verdes e da dificuldade de criação de novos espaços vegetados, o município de São Paulo tem buscado novas estratégias para a criação de parques, considerando uma delas a reutilização de áreas contaminadas. 
BASCH (2016) destaca que o controle da expansão urbana deve ser uma prioridade nas grandes cidades, devendo-se apostar na reutilização de áreas urbanas contaminadas como objeto de reaproveitamento e transformação. Cita o exemplo de Berlim, de reutilização da área ocupada pelo muro que outrora dividia a cidade, onde foram sendo criados espaços de recreação, utilizando partes da infraestrutura do edificado degradado.

A autora também destaca que áreas contaminadas com resíduos tóxicos apesar de serem espaços negligenciados e causarem um impacto negativo no ambiente e na comunidade envolvente, fazem parte da herança cultural do local promovendo, ao mesmo tempo, eficiência dos recursos naturais e de energia.

\subsubsection{Aspectos em Comum- Estudos de Casos}

No município de São Paulo, a implantação e os cuidados com as áreas verdes e parques públicos, podem ser de responsabilidade da administração municipal ou estadual, que fica à cargo da SVMA por intermédio do DEPAVE, ou ficam sob tutela das subprefeituras.

Nos estudos de caso pode-se comparar que as práticas adotadas no processo de requalificação apresentaram aspectos em comum e diferentes, mesmo as áreas estando localizadas dentro do município de São Paulo. Os principais aspectos em comum identificados estão relacionados à legislação, às fontes de contaminação, ao gerenciamento ambiental e a medidas de restrições para implantação de parques.

Como ainda não há uma legislação brasileira específica abordando o assunto em questão, as legislações adotadas como referência para o processo de requalificação e a implantação desses parques foram as estabelecidas pela CETESB, baseadas nos moldes da EPA, a partir do ano de 2005.

Aponta-se que áreas dos imóveis são pertencentes ao poder público, e que, em meados de 1960, foram utilizadas inicialmente para a atividade de mineração de areia, seguida posteriormente da disposição irregular de resíduos, caracterizando-se os locais como lixões.

À época, a prática de extração de areia era muito comum e muitas áreas que foram convertidas em áreas verdes, anteriormente abrigavam cavas de extração. Essas cavas, em sua maioria, na atual situação não têm nenhuma relação com os usos originais (SANCHES, 2014).

BONONI (2014) relata que, algumas áreas, em São Paulo, têm sido transformadas em áreas públicas, aproveitando as cavas de mineração. Como exemplo temos o Parque 
Ecológico de Embu das Artes, a Raia Olímpica da USP, o Parque do Ibirapuera e o Parque Cidade de Toronto.

Bitar 1997 (apud BONONI, 2014) cita que as áreas de lazer, recreação e esportes comunitários representam $21 \%$, e que todas iniciativas tomadas foram financiadas pelo poder público, sem nenhuma participação de investimentos privados. Contudo, o autor também enfatiza que essas áreas, uma vez não recuperadas, tornam-se vulneráveis a diversas atividades ilícitas, ocupação ilegal, comprometendo a qualidade de vida dos moradores do seu entorno. Outras cavas de mineração foram usadas para a disposição de resíduos sólidos urbanos diretamente no solo sem quaisquer critérios técnicos e medidas de proteção à saúde pública e ao meio ambiente, como na área dos parques selecionados.

SANCHES (2017) aponta que perante o contexto dos conflitos sociais e a marginalização presente nas grandes cidades como São Paulo, a transformação desses locais em áreas verdes mostra uma oportunidade na promoção do aumento da qualidade de vida da população, diminuindo a criminalidade e as tensões sociais, especialmente em zonas periféricas em expansão. Também ressalta que a ausência de áreas verdes não afeta apenas a qualidade de vida da população, como também pode causar desequilíbrios e processos naturais como inundações, o aquecimento do microclima urbano, a intensificação do efeito estufa e a erosão de encostas, colocando em risco a vida dos habitantes desses locais (SANCHES, 2014).

Considerando que em ambas áreas ocorreram a contaminação do solo e da água subterrânea, pode-se identificar que as investigações ambientais foram gerenciadas adequadamente seguindo o protocolo técnico do órgão ambiental, cujas ações foram iniciadas no ano de 2007, seguindo as legislações vigentes da CETESB.

Ficou evidenciado que o principal ponto levado em consideração para a requalificação das áreas, foi o risco aceitável da exposição para a saúde humana, visando a segurança dos futuros usuários e o princípio correto de funcionamento dos parques.

Nos 2 casos houve similaridades quanto às medidas exigidas para a área do parque: a restrição do uso da água subterrânea para qualquer finalidade dentro do imóvel; a cobertura final com solo limpo de preferência de origem argilosa; a restrição ao plantio de árvores frutíferas em todo imóvel; a construção de edificações e espaços confinados e o monitoramento dos gases e da água subterrânea. 


\subsubsection{Aspectos diferentes- Estudos de Casos}

De acordo com o procedimento do gerenciamento de áreas contaminadas e a Resolução Conama N. 420/2009, foi possível identificar que nem sempre os objetivos da requalificação de áreas contaminadas em São Paulo são alcançados com sucesso e garantidos pela abundante legislação brasileira.

Com base nos estudos de caso, identificou-se que houve um tratamento desigual no processo de requalificação, com destaque para três aspectos em específicos: os atores envolvidos no caso, o papel da sociedade civil e ação do Ministério Público.

No que tange os atores envolvidos, pode-se perceber a importância da participação privada em projetos de áreas contaminadas. Na área do Parque Estadual Villa-Lobos, com a presença do setor privado, foi possível que sua construção iniciasse rapidamente e sem tanta interrupção no decorrer da investigação ambiental. O setor privado foi o responsável pela construção que foi executada em partes, sendo totalmente concluído conforme projetado no ano 2013, demandando vinte e quatro anos.

É importante destacar que com a participação dos investidores e construtoras estes assumem dois papéis, o da viabilização financeiro-econômica e a execução da revitalização em si. Além disso, buscam e envolvem outros atores envolvidos, e juntos promovem a necessária sinergia para a requalificação da área.

Quanto ao Parque Municipal Jardim Primavera, ficou constatado que a administração municipal por mais que tenha se empenhado em atender todas as exigências voltadas para à segurança e requalificação da área, não conseguiu ter uma participação ativa e rápida no processo. Um fato que está relacionado com essa dificuldade é o de precisar exercer o papel do poder público e o de investidor ao mesmo tempo, dificultando a conclusão do projeto, que perdura até presente momento. Outra situação de grande relevância no processo de requalificação é o consenso entre as partes envolvidas na tomada de decisão, o que normalmente não acontece devido a eventuais conflitos de interesse. Porém, notou-se que no Parque Estadual Villa-Lobos houve esse consenso não havendo um conflito e sim gerando um ganho para todas as partes, que foi a conclusão do parque para a região.

MARKER (2013) afirma que a participação do setor privado em projetos de áreas contaminadas acaba cooperando com o setor público nas decisões e atendendo às expectativas da sociedade civil. Isso se deve ao fato de que são os responsáveis pela execução do projeto 
planejado e contratação de empresas especializadas constituídas por uma equipe capacitada, apta e responsável por toda implantação do projeto.

Outro fator observado no Parque Estadual Villa-Lobos foi a participação da vizinhança e população residente do entorno. Essa participação da população ocorreu desde desativação da área até a sua conversão total em parque. A sociedade civil, por meio das organizações não-governamentais (ONGs), participou ativamente de todo o processo de requalificação da área, uma vez que se beneficia do futuro uso e de ocupação do solo.

MORINAGA (2007) destaca que quando a inserção da população ocorre antes mesmo da elaboração do projeto, como no caso do Vila Lobos, acaba estimulando a educação ambiental, não apenas para informar sobre o problema, mas para proporcionar o conhecimento suficiente e de maneira adequada para a compreensão, transparência e decisões exatas do problema.

MARKER (2013) realça que um projeto exitoso de requalificação depende da participação de representantes da sociedade civil no processo de planejamento, da conversão do uso e ocupação de um terreno e na transparência de decisões urbanísticas, arquitetônicas e de remediação ambiental.

Além disso, identificou-se que, com a criação do Conselho de Orientação do Parque Estadual Villa-Lobos, o Estado conseguiu despertar o interesse da comunidade contando posteriormente com o seu apoio, diálogo e divulgação de todas as ações a respeito do processo de requalificação da área, de modo receptivo e transparente.

Já no Parque Municipal Jardim Primavera, a participação da comunidade se deu principalmente por meio de denúncias e reinvindicações feitas ao órgão ambiental, denunciando os riscos que o antigo aterro controlado oferecia e os problemas encontrados na tentativa da construção do parque.

Segundo BARROS (2011), que entrevistou o gestor do parque na época, foram realizadas pela SVMA audiências públicas sobre o projeto com a comunidade, porém muitos moradores não tinham conhecimento mínimo sobre o assunto, ficando sem entender de maneira clara a extensão do problema. Na época havia associações sem fins lucrativos que participavam das reuniões, mas não apresentavam coerência em suas ideias, o que ocasionou alguns conflitos de opinião pessoal e políticos.

O estudo também demonstrou que alguns moradores apresentavam uma grande inquietação relacionada a não conclusão da obra, e ao mesmo tempo uma grande desmotivação oriunda de alguns fatores como: promessas feitas pelo poder público no 
decorrer dos anos anteriores; a demora para iniciar a implantação do parque; a indecisão na opinião e gestão sobre o futuro da área e a ausência de informação sobre a situação da atual da área. Isso, de certa forma, fez com o que a população criasse falsas expectativas e conflitos futuros, gerando um descrédito sobre o poder público em relação à representatividade e efetividade sobre os reais objetivos da área.

Segundo SILVA E PELICIONI (2014) a participação social é uma das principais formas de estimular a população na identificação, planejamento e implementação de ações que colaborem para a criação de ambientes mais saudáveis e a melhoria da qualidade de vida. Entretanto, nota-se que na área do Parque Municipal Jardim Primavera não houve um momento participativo de troca direta e consciente por meio da educação, e sim apenas encontros e espaços de consultas sem instância participativa entre representantes e representados.

PEDRO (2014) enfatiza que a audiência pública não é assembleia deliberativa nem reunião de condomínios ou acionistas para qual se deva observar protocolos previstos em estatutos para garantir apoios para o que ali se vai decidir. $\mathrm{O}$ autor relata que audiência pública é um momento a ser registrado no procedimento de licenciamento ambiental, para que seja posteriormente considerado pela autoridade que vai decidir sobre a viabilidade ou não do projeto proposto. Nesse ponto, identifica-se que quanto maior a organização da comunidade mais qualificada será a sua participação e, consequentemente, mais democratizado será o processo de tomada de decisão.

JACOBI (2004) destaca para o fato de que no Brasil, quando o assunto se refere à participação e espaços públicos é comum o desinteresse da participação da sociedade civil, pois isto está diretamente marcado pelo descrédito nos políticos e nas instituições. Entretanto, a participação da sociedade nas questões ambientais é de grande importância e está na prevista na Lei $n^{\circ}$ 6.938/81 da Política Nacional do Meio Ambiente, que tem dentre os seus objetivos "a divulgação de dados e informações ambientais e a formação de uma consciência pública sobre a necessidade de preservação da qualidade ambiental e do equilíbrio ecológico" (BRASIL, 1981. art. $\left.4^{\circ}, \mathrm{V}\right)$.

PEDRO (2014) destaca que por meio do direito à informação é que se institui um dever-poder, ou seja, o conjunto do poder público e da coletividade (Estado e Sociedade) de modo participativo e ativo dos diferentes grupos e segmentos interessados na formulação e execução das circunstâncias de decisão. $\mathrm{O}$ autor também ressalta que o acesso à informação confere melhores condições de interação social para vincular-se as demandas na formulação 
de políticas públicas, demandas por melhor qualidade de vida, autonomias e tomada de decisão.

O poder público, perante a essa situação, deve assumir e apresentar uma função mais educativa, efetiva e qualificada na questão da implantação do Parque Municipal Jardim Primavera no que tange aos problemas reais que afetam a área. Também se faz necessário o acesso à informação, divulgação e explicação de forma objetiva de como será feita essa requalificação para a região como um todo, deixando todas as interfaces claras.

Outra questão identificada de grande relevância no processo de requalificação, quanto se trata de áreas contaminadas e a implantação de parques, é a participação do Ministério Público (MP).

Segundo a Constituição da República Federativa do Brasil de 1988 (art. 127), o MP é uma instituição permanente, essencial à função jurisdicional do Estado, incumbindo-lhe a defesa da ordem jurídica, do regime democrático e dos interesses sociais e individuais indisponíveis. Entre suas funções podem atuar como fiscal de lei, assim como, promover o inquérito civil e a ação civil pública para a proteção do patrimônio público e social, do meio ambiente e de outros interesses difusos e coletivos (BRASIL, 1988).

Ao que tange as questões ambientais, no Brasil de acordo com a Constituição Federativa Brasileira (art. 225, $\S 3^{\circ}$ ) e a Lei 6.938/1981 (art. $4^{\circ}$, inciso VII) da Política Nacional de Meio Ambiente foi instituído que uma vez causado o dano ambiental, este deverá ser sempre reparado de modo integral (MP, 2011). Esse reparo integral é considerado uma vertente econômica determinante na esfera da sustentabilidade, pois enquadra-se no Princípio do Poluidor-Pagador, que surgiu no princípio 16 da Declaração da Conferência da Nações Unidas do RIO 92, definido como: "aquele que contamina deve, em princípio, arcar com os custos da contaminação" (PEDRO, 2014).

Para tanto, as autoridades nacionais devem promover a internalização dos custos ambientais e o uso de instrumentos econômicos, levando na devida conta o interesse público, sem distorcer o comércio e os investimentos internacionais (RIO, 1992). Nesse sentido, o MP no âmbito do seu poder judiciário, entende que o poluidor é obrigado, independentemente da existência de culpa, de recuperar por completo o equilíbrio ecológico e as funções e serviços do ecossistema afetado. Basta a demonstração da existência de um nexo de causalidade entre sua atividade e o dano.

Entretanto, quando se analisa essa ideia em uma área contaminada como os Parques avaliados, identifica-se divergências existentes entre as normas vigentes relativas à 
recuperação de áreas contaminadas versus reparação do dano ambiental. Essas divergências ainda que se encontrem em discussões e debates de grandes eventos técnicos, muitas vezes acarretam conflitos jurídicos entre os atores envolvidos, o que pode comprometer diretamente a requalificação urbana e o desenvolvimento sustentável do uso do solo de importantes regiões do município de São Paulo.

Como na área do parque ainda há resíduos soterrados, fica registrado que é inviável a recuperação total do dano ambiental causado, ou seja, é impossível se ter um meio ambiente ecologicamente equilibrado como preconizado por todo arcabouço legislativo voltado para dano ambiental, e sua recuperação.

O art. 4, VI da Lei 6.938/1981 estabeleceu a "preservação e restauração dos recursos ambientais com vistas à sua utilização racional e disponibilidade permanente, concorrendo para a manutenção do equilíbrio ecológico propício à vida", o que implica ao poluidor a obrigação de recuperar e/ou indenizar os danos causados de sua atividade.

Portanto, de acordo com a Resolução CONAMA N.420/2009 e a Lei Estadual 13.577/2009, o processo de recuperação de áreas contaminadas não garante a promoção da recuperação da qualidade ambiental anterior à contaminação, pois tem como objetivo a adoção de medidas corretivas baseadas no conjunto de ações que visam a isolar, conter, minimizar ou eliminar a contaminação, possibilitando recuperá-las para um uso compatível com as metas estabelecidas a ser atingida após a intervenção, adotando-se dessa forma o princípio do uso declarado.

Com essa reabilitação da área é possível uma nova ocupação, seja ela residencial, comercial ou agrícola, e este é um procedimento adotado amplamente em todo o mundo. Sendo assim, nessa área ainda podem restar passivos ambientais que expõem receptores ecológicos a riscos, ou podem impor restrições de uso do solo e da água subterrânea, o que de certa forma acaba afrontando o disposto na Lei 6.938/1981 (artigo $2^{\circ}$ incisos IV e VIII), bem como o artigo 225 da Constituição Federativa Brasileira, em função de não assegurar um meio ambiente ecologicamente equilibrado.

Art. 225. Todos têm direito ao meio ambiente ecologicamente equilibrado, bem de uso comum do povo e essencial à sadia qualidade de vida, impondo-se ao Poder Público e à coletividade o dever de defendê-lo e preservá-lo para as presentes e futuras gerações (BRASIL, 1988). 
Desta forma, percebe-se que a reparação integral do dano ambiental conforme tratada no Relatório do Grupo de Trabalho do MPSP, criado pelo Ato PGJ n 36/2011, não será alcançada com a aplicação das normas específicas ao GAC (MPSP, 2011).

BERTOLO et al. (2019) apontam que o GAC parte do princípio de que a recuperação da aptidão para determinado uso do solo é mais viável técnica e economicamente do que a reparação integral das funções e serviços ecossistêmicos originais. Além disso, nos casos de áreas urbanas o GAC visa preservar a saúde humana e o meio ambiente na área recuperada, mas permite a presença de alguma quantidade do contaminante em concentrações seguras para o uso futuro declarado.

Nesse sentido, identifica-se que a tese jurídica formulada e defendida pela MPSP, ao que tange áreas contaminadas, apresenta-se em contraponto à remediação regulamentada e praticada no estado, sendo necessário um consenso entre o poder público sobre a questão da valoração do dano ambiental em que se possa admitir, a princípio, outra forma de reparação ambiental que não seja a integral.

Outro ponto a destacar é a participação do MPSP no caso do Parque Estadual VillaLobos. Neste caso, o mesmo não ingressou com pedido de liminar contra Estado, e sim participou de uma ação civil pública entre sociedade civil (requerente) contra o governo do Estado (requerido) para um acordo.

Nesse acordo havia vários questionamentos da população sobre o parque, alguns incompletos e outros em andamento, os quais em sua maioria precisavam ser melhorados. Um desses atos estava relacionado ao tempo de cumprimento do prazo para a abertura do parque: “considerando que não atende ao interesse público a demora da abertura de toda a área do Parque Estadual Villa-Lobos à população” (MPSP, 2006).

Outro ponto que vale ressaltar é que o Parque Estadual Villa-Lobos, por ter conseguido iniciar rapidamente os primeiros estudos ambientais para averiguação da contaminação na área, pôde evitar esse trâmite jurídico e o desvirtuamento das finalidades planejadas para a área, como o identificado pela área do Parque Municipal Jardim Primavera. De certa forma, aponta-se que a ação judicial promovida pela população nesse quesito, acabou contribuindo com o Estado, mostrando a importância do princípio da participação no processo de decisão.

Também se observa que, por meio dessa ação judicial, o Estado adotou todas as providências preconizadas pela CETESB vigentes à época, adequando-se aos padrões legais e 
aos níveis de agentes contaminantes aceitáveis, tendo em vista o uso declarado, ou seja, a recuperação de áreas contaminadas e não recuperação integral do dano ambiental.

Sendo assim, entende-se que todos têm o direito ao meio ambiente ecologicamente equilibrado e que a responsabilidade ambiental é a forma encontrada pelo Direito para compelir o responsável a satisfazer sua obrigação de gestão ambiental dentro de um desenvolvimento urbano. Portanto, no que tange áreas contaminadas, há necessidade de um instrumento efetivo para áreas urbanas, objetivando conciliar as diferentes exigências de projetos de desenvolvimento sustentável do uso do solo, promovendo a melhoria do meio e a recuperação dos compartimentos ambientais afetados.

Também pressupõe que, por meio do acesso às informações, a comunidade tenha melhores condições de atuar sobre a sociedade, de formar uma mobilização eficaz para atender os desejos e ideias, além de fazer parte ativa nas decisões de assuntos que lhe interessem e afetem diretamente (PEDRO, 2014).

\subsection{FATORES DE SUCESSO NO PROCESSO DE REQUALIFICAÇÃO}

Com base nas experiências e práticas internacionais adotadas e consideradas bemsucedidas, ficou constatado que as políticas públicas existentes voltadas ao gerenciamento e a requalificação de áreas contaminadas, só conseguiram adquirir o sucesso esperado, em função da criação de mecanismos de incentivos fiscais e leis específicas que estimulem a recuperação ambiental e urbanística.

O quadro 22, demonstra os mecanismos e ferramentas usadas no contexto internacional identificadas no processo de requalificação em áreas contaminadas.

Quadro 22- Mecanismos essenciais no processo de requalificação no contexto internacional.

\begin{tabular}{|c|}
\hline Fundos nacionais para áreas contaminadas órfãs \\
\hline Lista de áreas contaminadas prioritárias \\
\hline Criação de impostos \\
\hline Apoio financeiro e parceria com setor privado \\
\hline Parceria entre os órgãos competentes (federais, estados e municípios) \\
\hline Participação da sociedade civil no processo de revitalização \\
\hline Descentralização e flexibilização da legislação de proteção ao solo \\
\hline
\end{tabular}

Elaborado pela autora. 
Fica evidenciado que mesmo no estado de São Paulo, o pioneiro em reabilitação de áreas contaminadas, há uma grande carência de fatores essenciais que visem atrair investimentos voltados para a reutilização dessas áreas. MORINAGA (2017) ressalta que a reutilização de áreas contaminadas não se viabiliza apenas por meio de mecanismos de mercado, e que se faz necessária a existência de um arcabouço legal, além de instrumentos de incentivo fiscal que estimulem a requalificação ambiental.

O Estatuto da Cidade, aprovado pela Lei Federal N.10.257/2001, regulamenta e estabelece as normas relativas à política urbana, instituindo uma série de instrumentos que visam garantir o desenvolvimento das funções sociais e da propriedade urbana da cidade, bem como o equilíbrio ambiental (BRASIL, 2001).

Alguns instrumentos estabelecidos em prol da política urbana da cidade foram incorporados no município de São Paulo através do Plano Diretor Estratégico (PDE) aprovado pela Lei N.13.430/2002, em vigor atualmente pela Lei $N^{\circ} 16.050 / 2014$. Entre os instrumentos, destaca-se que fundos municipais existentes, como o Fundo Especial do Meio Ambiente e Desenvolvimento Sustentável (FEMA) aprovado pela Lei Municipal No 13.155/2001, vinculado a SVMA, e Fundo de Desenvolvimento Urbano (FUNDURB), instituído pelo Plano Diretor Estratégico e regulamentado pelo Decreto $\mathrm{N}^{\circ} 43.231 / 2003$, seriam mecanismos de financiamento para se obter recursos de forma direta destinadas as áreas contaminadas.

Entende-se que a Prefeitura de São Paulo poderia ter uma postura mais participativa e eficaz nessa questão, dispondo de recursos para o processo de requalificação e/ou financiar projetos que visem a melhoria e/ou recuperação da qualidade ambiental de forma sustentável. Além disso, a fonte de receita do FEMA é oriunda da aplicação principalmente de multas por infrações ambientais, indenizações, valores advindos de contratos, convênios, valores referentes ao uso do espaço público, como as taxas cobradas em parques municipais (SVMA, 2020). Entretanto, MORINAGA (2017) ressalta que mesmo o município dispondo desses fundos, o ideal seria criar um fundo específico de áreas contaminadas, pois as ações de investigações e remediação da contaminação são fundamentais para viabilizar a recuperação das áreas afetadas.

No âmbito estadual, a Lei No 13.577/2009 instituiu o Fundo Estadual para Prevenção e Remediação de Áreas Contaminadas (FEBRAC), fundo de investimento vinculado à Secretaria do Meio Ambiente do Estado de São Paulo, que tem por finalidade ser utilizado na proteção do solo, bem como à identificação e à remediação de áreas. 
Os recursos do FEBRAC (artigo 32) seriam aplicados em operações financeiras destinadas a apoiar e a incentivar ações relacionadas a identificação e remediação de áreas contaminadas, visando eliminar o perigo iminente à saúde pública (SÃO PAULO (estado), 2009). Neste caso, o responsável legal pela área será acionado para efetuar o ressarcimento ao estado pelos custos de identificação e remediação (MORINAGA, 2017).

Um outro instrumento de incentivo, seria através do Imposto Predial e Territorial Urbano (IPTU) Progressivo em Tempo criando um fundo municipal de incentivo fiscal específico, despertando o interesse do proprietário ou do interessado principalmente do setor privado para reutilizar e requalificar áreas contaminadas. Os custos da recuperação ambiental poderiam ser abatidos de forma total ou parcial no IPTU do imóvel.

Em consonância com o Plano Diretor Estratégico, o artigo 90 poderia ser utilizado para induzir o proprietário da área contaminada (subutilizada ou não utilizada) a participar do processo de sua recuperação, como instrumento de incentivo.

\footnotetext{
Artigo 90- O executivo, na forma da lei, poderá exigir do proprietário do solo urbano não edificado, subutilizado, ou não utilizado, que promova seu adequado aproveitamento, sob pena, sucessivamente, de:

I - parcelamento, edificação ou utilização compulsórios;

II- Imposto Predial e Territorial Urbano Progressivo no Tempo;

III-desapropriação com pagamento mediante títulos da dívida pública (SÃO PAULO (cidade), 2014).
}

Ainda de acordo com o art. 90, o poder público por meio da desapropriação com pagamento mediante títulos da dívida pública poderia utilizar como incentivo, abatendo-se o valor de recuperação do passivo ambiental e possibilitando a implantação de área de recreação e lazer, dando prioridade aos parques. Portanto, também seria necessária a criação de uma lei municipal específica incluindo essa ferramenta, assim como suas regras de funcionamento e controle das áreas.

SEPE E SILVA (2004) relatam que outra opção possível para incluir investimentos em recuperação ambiental de áreas contaminadas seria por meio de cada Operação Urbana Consorciada (OUC) aprovada no município.

No artigo 138 do PDE estão apontadas algumas intervenções e medidas de sua competência, porém observa-se que mesmo a requalificação de área contaminada sendo 
citada, a criação de áreas verdes não se apresenta como prioritária de transformações urbanísticas.

Artigo138- Operações Urbanas Consorciadas têm por finalidade:

I- otimizar a ocupação de áreas subutilizadas, por meio de intervenções urbanísticas; II - implantar equipamentos estratégicos para o desenvolvimento urbano;

III- ampliar e melhorar o sistema de transporte coletivo, as redes de infraestrutura e o sistema viário estrutural;

IV- promover a recuperação ambiental de áreas contaminadas e áreas passíveis de inundação (grafo nosso);

V- implantar equipamentos públicos sociais, espaços públicos e áreas verdes (grafo nosso);

VI - promover Empreendimentos de Habitação de Interesse Social e urbanizar e regularizar assentamentos precários;

VII- proteger, recuperar e valorizar o patrimônio ambiental, histórico e cultural;

VIII - promover o desenvolvimento econômico e a dinamização (SÃO PAULO (cidade), 2014).

Outra ferramenta viável que poderia ser utilizada seria a concessão urbanística. Neste caso, o poder público, ao delegar a realização de obras de uma determinada área a uma empresa ou consórcio, em regiões com potencial de contaminação ou contaminada, poderia vincular a obrigatoriedade ao concessionário de realizar as investigações ambientais, cujas informações deveriam ser tomadas com base na elaboração do plano urbanístico (MORINAGA, 2017).

Na esfera federal, identifica-se que ainda que a PNRS (art. 42, VI), tenha determinado que o poder público poderá instituir medidas indutoras e linhas de financiamento criando um fundo nacional, para atender prioritariamente às iniciativas de descontaminação de áreas contaminadas, incluindo as áreas órfãs, tal fato ainda não foi realizado (BRASIL, 2010).

Art. 42. O poder público poderá instituir medidas indutoras e linhas de financiamento para atender, prioritariamente, às iniciativas de:

I- prevenção e redução da geração de resíduos sólidos no processo produtivo;

II- desenvolvimento de produtos com menores impactos à saúde humana e à qualidade ambiental em seu ciclo de vida;

III- implantação de infraestrutura física e aquisição de equipamentos para cooperativas ou outras formas de associação de catadores de materiais reutilizáveis e recicláveis formadas por pessoas físicas de baixa renda;

IV- desenvolvimento de projetos de gestão dos resíduos sólidos de caráter intermunicipal ou, nos termos do inciso I do caput do art. 11, regional;

V - estruturação de sistemas de coleta seletiva e de logística reversa;

VI - descontaminação de áreas contaminadas, incluindo as áreas órfãs (grafo nosso); 
VII - desenvolvimento de pesquisas voltadas para tecnologias limpas aplicáveis aos resíduos sólidos;

VIII - desenvolvimento de sistemas de gestão ambiental e empresarial voltados para a melhoria dos processos (BRASIL, 2010).

Contudo, observa-se que em seu no artigo 48, é apontado que nas áreas de disposição final de resíduos ou rejeitos, fica "proibida a fixação de habitações temporárias ou permanentes", ou seja, ficando restrita a construção de habitações (BRASIL, 2010). Este cenário é bem diferente do identificado em quatro áreas públicas de antigos aterros controlados localizados no município de São Paulo (Jardim Damasceno, Pedreira City, Pedreira Itapuí e Vila São Francisco), havendo loteamentos habitacionais configurados em sua maioria em favelas.

Além disso, o Decreto Estadual No 59.263/2013, apresenta pontos relevantes quanto à importância de incentivar o processo de reutilização como forma de promover a reabilitação de áreas contaminadas, evidenciando que esse incentivo deve partir do poder público, identificado nos artigos a seguir.

Artigo 2- Constitui objetivo da Lei $\mathrm{n}^{\circ} 13.577$, de 8 de julho de 2009, garantir o uso sustentável do solo, protegendo-o de contaminações e prevenindo alterações nas suas características e funções, por meio:

V - promoção da remediação de áreas contaminadas e das águas subterrâneas por elas afetadas;

VI - incentivo à reutilização de áreas remediadas;

VII - promoção da articulação entre as instituições (SÃO PAULO (estado), 2013).

Artigo 4- São instrumentos, dentre outros, para a implantação do sistema de proteção da qualidade do solo e para o gerenciamento de áreas contaminadas:

VIII - Incentivos fiscais, tributários e creditícios;

XIV - Fundos financeiros (SÃO PAULO (estado), 2013).

E sobre a reutilização de áreas contaminadas, é ressaltado que:

Artigo 61- A aquisição de terrenos onde são ou foram desenvolvidas atividades com potencial de contaminação com vistas à sua revitalização será considerada como de interesse público, devendo ser incentivada e apoiada pelos poderes públicos estadual e municipal (SÃO PAULO (estado), 2013).

No Brasil, em específico na cidade de São Paulo, os fundos e incentivos fiscais existentes não permitem uma aplicação específica para o fomento à requalificação de áreas 
contaminadas diretamente, embora citadas em algumas legislações e passíveis de reformulações.

MORINAGA (2017) afirma que o emprego de mecanismos de incentivo em áreas contaminadas mantém forte relação com o interesse do mercado imobiliário e com fatores locacionais, influenciando diretamente na escolha de áreas para a realização de investimentos. Além disso, nota-se a importância do papel incisivo do poder público em áreas menos atrativas e carentes, visando buscar mecanismos de incentivo para o processo de requalificação e condições de melhoria de vida da população nessas áreas.

SANCHES (2014) indica que os principais obstáculos que estão relacionados com os instrumentos de incentivo são: o alto custo das obras e projetos de remediação; a ausência de demanda por parte dos investidores; a dificuldade na aquisição de novas áreas privadas, pois nem sempre pertencem apenas a um proprietário; a divergência de interesse sobre o destino futuro da área; a incerteza e atrasos nos projetos e transições do governo e os possíveis conflitos entre os níveis de poder.

Esses obstáculos chamam a atenção para a importância e a necessidade das parcerias de instituições público-privadas como meio facilitador nos projetos de requalificação de áreas contaminadas. Outro aspecto que vale lembrar é a necessidade de uma legislação específica, ainda indisponível, para que se possa buscar e estimular a participação do setor privado. Em geral, nos países de baixa e média renda, os incentivos à recuperação e requalificação de áreas contaminadas, ainda são escassos em comparação a países de alta renda. Contudo, mesmo com a ausência desses recursos, fundos e incentivos fiscais para áreas contaminadas, o poder público vem tentando reutilizar áreas e implantar parques dentro do território urbano. 


\section{CONSIDERAÇÃO FINAIS E RECOMENDAÇÕES}

Pelas análises internacionais e pelos estudos de caso do Brasil, foi possível identificar que o processo de requalificação de áreas contaminadas por resíduos sólidos e sua transformação em parques, tem um grande potencial de criação de áreas de utilidade pública, de modo benéfico para a qualidade de vida da população, assim como o espaço urbano.

Os casos estudados permitiram conhecer que as áreas contaminadas por resíduos sólidos, consideradas como casos de sucesso no município de São Paulo, tiveram o apoio direto da sociedade civil e do poder público complementado com a iniciativa privada. Outra questão, é que para que esses projetos urbanísticos sejam feitos com maior profundidade e facilidade, é necessário que ocorra a reformulação e/ou modificação na legislação brasileira, em especial na tese de Reparação Integral defendida pelo Ministério Público versus Gerenciamento de Áreas contaminadas.

Baseado no conhecimento adquirido das práticas internacionais para as ações futuras em outras áreas contaminadas por resíduos sólidos, não somente para o município de São Paulo e sim para o país, recomenda-se primeiramente que se estude a área/local contaminado de forma minuciosa, para que seja possível identificar sua interação com o meio e com seu entorno. Além disso, no planejamento de requalificação deve-se identificar se o ideal é realmente um projeto de parque para a área, e se há outra opção de utilidade pública para a mesma, por exemplo, uma praça com arborização.

Outro fator importante, é respeitar as condições naturais do local, mudando apenas o necessário, e quando alterado, buscar projetos que demandam baixos custos de manutenção, evitando-se assim, novos espaços degradados, abandonados e/ou ociosos pela cidade. Se faz necessário considerar os ganhos e impactos para a região com a nova requalificação da área, assim como suas atribuições /responsabilidades, seja em termos sociais, ambientais, econômicos, culturais, etc.

Ficou evidente que antes de sancionar uma lei criando um parque, o poder público precisa estimular/inserir a participação privada diretamente nos projetos de áreas contaminadas, pois eles são essenciais para casos não concluídos como o Parque Municipal Jardim Primavera. Também, deve agir ativamente e inserir o apoio da sociedade civil no processo de requalificação de modo direto, possibilitando o conhecimento in loco, na prática. 
E por fim, precisa buscar o apoio de outros órgãos competentes como o de política urbana, saúde pública, visando criar soluções e projetos melhores de requalificação de áreas contaminadas por resíduos como uma ferramenta de desenvolvimento urbano sustentável do uso do solo e de promoção da qualidade de vida.

Destacam-se como pontos positivos da pesquisa a abrangência e a visão interdisciplinar sobre o tema. A análise permitiu explorar diversos tipos de requalificação de áreas contaminadas por resíduos em contraponto com a literatura existente.

Recomenda-se a exploração mais aprofundada dos temas discutidos na dissertação e a avaliação das ações do poder público em relação às áreas contaminadas por resíduos. Ainda que se tenha proposto ações voltadas para a criação de parques nessas áreas, é importante que haja o fortalecimento no processo de legislação, planejamento, fiscalização e monitoramento para que dessa forma, se obtenha como resultado final, casos de sucesso. 


\section{REFERÊNCIAS}

ABNT- Associação Brasileira de Normas Técnicas. NBR 13.896. Aterros de resíduos não perigosos - Critérios para projeto, implantação e operação. Rio de Janeiro. Jun. 1997.

ABRELPE- Associação Brasileira de Empresas de Limpeza Pública e Resíduos Especiais. Panorama dos Resíduos Sólidos no Brasil 2018/2018. São Paulo. 2018/2019. p. 11-12.

AMARO, A. Y. G; SILVA, A. M; MUSTAFÁ, A. M. M; COSTA, C. S; MORTOZA, A. M; OLIVEIRA, I. B. B. A importância de uma boa gestão de resíduos sólidos. Journal Technology and Business Facit, v.8, n.2, p.45-52. 2018.

AMLURB-Autoridade Municipal de Limpeza Urbana do Estado de São Paulo. Resíduos Sólidos. São Paulo, maio. 2019. Disponível em: $<$ https://www.prefeitura.sp.gov.br/cidade/secretarias/subprefeituras/amlurb/residuos_solid os/index.php?p=229517>. Acesso em: 20 ago. 2019.

Coleta Domiciliar: Aterros sanitários e transbordos. São Paulo, set. 2009. Disponível:<https://www.prefeitura.sp.gov.br/cidade/secretarias/regionais/amlurb/aterros_ e_transbordos/index.php?p=4633>. Acesso em: 18 ago. 2018.

ATSDR- Agency for Toxic Substances and Disease Registry. ATSDR Land Reuse Health Program. USA. Disponível em: <https://www.atsdr.cdc.gov/sites/brownfields/index.html>. 2019. Acesso em: 28. Nov. 2019.

BARROS, L. H. S. Requalificação dos aterros desativados (browfields) no município de São Paulo: Parques (greenfields) Raposo Tavares e Jardim Primavera. 2011. 408f. Tese de Doutorado (Área de Concentração: Paisagismo e Ambiente) - Faculdade de Arquitetura e Urbanismo da Universidade de São Paulo, FAU/USP, São Paulo, 2011.

A paisagem requalificada: dos lixões aos parques urbanos. In: PELLEGRINO, P; MOURA, N. B (Orgs.). Estratégias para uma infraestrutura verde. Barueri- São Paulo: Manole, 2017. p.261-289.

BARTON, J; PRETTY, J. N. What is the Best Dose of Nature and Green Exercise for Improving Mental Health? A Multi-Study Analysis. Environmemtal Science \& Technology, v.44, n.10. 2010. P.3947- 3955.

BASCH, A. Ecobairro: Uma proposta para a regeneração sustentável da zona do Parque Mayer. 2016. 85f. Dissertação (Mestrado- Àrea de Concentração: Arquitetura). Faculdade de Arquitetura da Universidade de Lisboa, Lisboa. 2016.

BBC NEWS- Sudeste Asiático se revolta contra os resíduos do Ocidente: "Não seremos o lixão do mundo". Junho, 2019. Disponível em: <https://www.bbc.com/portuguese/geral-48489791>. Acesso em: 05. Jun. 2019. 
BERTOLO, R. A; HIRATA, R; ALY JUNIOR. O. Método de Valoração da Água Subterrânea Impactada por Atividades Contaminantes no Estado de São Paulo, Revista Águas Subterrâneas, v. 33, n. 3, p. 303-313, 2019.

BNDES- Banco Nacional de Desenvolvimento Econômico e Social. Análise das Diversas Tecnologias de Tratamento e Disposição Final de Resíduos Sólidos no Brasil, Europa, Estados Unidos e Japão. Brasil: dez. 2013. 186 p.

BONONI, V. L.R. Controle Ambiental de Áreas Verdes. In: PHILIPPI JR, A; ROMÉRO, M. A; BRUNA, G. C (eds). Curso de Gestão Ambiental. v.13, 2 ed. Barueri, São Paulo: Manole, 2014. p. 257-305.

BRANSKI, R. M; FRANCO, R. A. C; LIMA, O. F. Metodologia de estudo de casos aplicada à logística. São Paulo, Campinas: 2015. Disponível em: <http://lalt.fec.unicamp.br/scriba/files/escrita\%20portugues/ANPET\%20\%20METODOL OGIA\%20DE\%20ESTUDO\%20DE\%.pdf >. Acesso em: 10 mar. 2019.

BRASIL. Constituição da República Federativa do Brasil de 1988. Capítulo IV-Meio ambiente. Diário Oficial da União, de 05 de outubro de 1988. Poder Executivo, Brasília, DF. 1988.

. Lei N. 1.413, de 31 de julho de 1975. Dispõe sobre o controle da poluição do meio ambiente provocada por atividades industriais. Diário Oficial da União de 31 de julho de 1975. Poder Executivo, Brasília, DF, 01 de agosto de 1975. Seção I.

Lei N. 12.305/2010, de 2 de agosto de 2010. Institui a Política Nacional de Resíduos Sólidos; altera a Lei N. 9605, de 12 de fevereiro de 1998; e dá outras providências. Diário Oficial da União de 02 de agosto de 2010. Poder Executivo, Brasília, DF, 03 de agosto de 2010. Seção I. p 2.

. Lei N. 6.514, de 22 de julho de 2008. Dispõe sobre as infrações e sanções administrativas ao meio ambiente, estabelece o processo administrativo federal para apuração destas infrações, e dá outras providências. Diário Oficial da União, de 22 de julho de 2008. Poder executivo, Brasília, DF, 23 de julho de 2008. Seção I. p. 1.

. Lei N. 6.766, de 19 de dezembro de 1979. Dispõe sobre o Parcelamento do Solo Urbano e dá outras Providências.. Diário Oficial da União de 19 de dezembro de 1979. Poder Executivo, Brasília, DF, 20 de dezembro de 1979. Seção I. p. 19457.

Lei N. 6.981, de 31 de agosto de 1981. Dispõe sobre a Política Nacional do Meio Ambiente, seus fins e mecanismos de formulação e aplicação, e dá outras providências. Diário Oficial da União de 31 de agosto de 1981. Poder Executivo, Brasília, DF, 02 de setembro de 2002. DF, Seção I.

Lei N.10.257, de 10 de julho de 2001. Regulamenta os arts. 182 e 183 da Constituição Federal, estabelece diretrizes gerais da política urbana e dá outras providências. Diário Oficial da União de 10 de julho de 2001. Poder Executivo, Brasília, DF, 11 de julho de 2001. Seção I. 
BRASIL. Ministério da Saúde. Secretaria de Vigilância em Saúde. Coordenação-Geral de Vigilância Ambiental em Saúde. Avaliação de risco à saúde humana por resíduos de pesticidas organoclorados em Cidade dos Meninos, Duque de Caxias, RJ, 2002. Brasília, DF: 2004. 79p.

BRASIL. Resolução Conama. N. 273, de 29 de novembro de 2000. Estabelece diretrizes para o licenciamento ambiental de postos de combustíveis e serviços e dispõe sobre a prevenção e controle da poluição. Diário Oficial da União, de 29 de novembro de 2000. Poder Executivo, Brasília, DF, 8 de janeiro de 2001. SP. Seção I. p. 20-23.

$\mathrm{N}^{\mathrm{o}} 420$, de 28 de dezembro de 2009. Dispõe sobre critérios e valores orientadores de qualidade do solo quanto à presença de substâncias químicas e estabelece diretrizes para o gerenciamento ambiental de áreas contaminadas por essas substâncias em decorrência de atividades antrópicas. Diário Oficial da União de 28 de dezembro de 2009. Poder Executivo, Brasília, DF, 30 de dezembro de 2009. № 249, p. 81-84.

CANÁRIO, P. G. G. Processo de investigação de áreas contaminadas: análise crítica e estudo de caso. 2018. 120f. Dissertação (Mestrado - Área de Concentração: Sistemas de Infraestrutura Urbana) - Pontifícia Universidade Católica de Campinas, PUC/ Campinas. 2018.

CANDIANI, G; VIANA, E. Emissões fugitivas de metano em aterros sanitários. GEOUSP- Espaço e Tempo (online), v.21, n.3, p.845-857, dez. 2017.

CE- Commission European. Proposta de Directiva do Parlamento Europeu e do Conselho que altera a Directiva 1999/31/CE relativa à deposição de resíduos em aterros. Bruxelas, dez. 2015. 14p.

Directiva 94/62/CE do Parlamento Europeu e do Conselho de 20 de Dezembro de 1994 relativa a embalagens e resíduos de embalagens. Jornal Oficial da União Europeia, L365/10 de 31/12/1994. p. 10-23.

$\begin{array}{cccc}\text { Ehttp://ec.europa.eu/environment/waste/landfill }>\text {. Acesso em: } & \text { 201/06/2019. } & \text { Disponível }\end{array}$

CETESB- Companhia Decisão de Diretoria No 38/2017/C, de 07 de fevereiro de 2017. Dispõe sobre a aprovação do "Procedimento para a Proteção da Qualidade do Solo e das Águas Subterrâneas", da revisão do "Procedimento para o Gerenciamento de Áreas Contaminadas" e estabelece "Diretrizes para Gerenciamento de Áreas Contaminadas no Âmbito do Licenciamento Ambiental", em função da publicação da Lei Estadual $n^{\circ}$ 13.577/2009 e seu Regulamento, aprovado por meio do Decreto $n^{\circ} 59.263 / 2013$, e dá outras providências. Diário Oficial do Estado de São Paulo de 07 de fevereiro de 2017. Poder Executivo, São Paulo, SP, 10 de fevereiro de 2017. Seção 1, Edição nº 127. p. 47 a 52. 2017. 
. Certificado de Movimentação de Resíduos de Interesse Ambiental (CADRI). $\mathrm{N}^{\circ}$ processo 45005831. Jul. 2014. Disponível em: $<$ http://autenticidade.cetesb.sp.gov.br/autentica.php?docmn=30011498. Acesso em: 08 out. 2018.

Guia para avaliação do potencial de contaminação em imóveis. São Paulo: CETESB: GTZ, 2003. Disponível em: <https://cetesb.sp.gov.br/camaras-ambientais/wpconte/uploads/t_con_imoveis.pdf>. Acesso em: 17. ago. 2018.

Inspeção Técnica ao Aterro Sanitário Jacuí. SI/30.0002/98. Mai. 1998. 5fls.

. Manual de gerenciamento de áreas contaminadas. CETESB/GTZ. 2 ed. São Paulo: 2001.Disponível em: <https://cetesb.sp.gov.br/manual-de-gerenciamento-de-areascontaminadas/>. Acesso em: 18 mar. 2018.

3fls.

Projeto do Aterro Sanitário do Jacuí. Parecer Técnico 01/84/DRD. Fev. 1984.

Relatório de Áreas Contaminadas de São Paulo 2019. Dezembro, 2019. São

Paulo. Disponível em: <https://cetesb.sp.gov.br/areas-contaminadas/relacao-de-areascontaminadas/>. Acesso em 05 fev. 2020. p. 1-12.

. Solicitação de Abertura Parcial do Parque Jardim primavera (Antigo Aterro Jacuí) - Fase I. Parecer Técnico 014/CAAR/2017. Maio. 2017a. 2fls.

Valores Orientadores para Solos e Águas Subterrâneas no Estado de São Paulo- DD 256/2016. Disponível em: <https://www.cetesb.sp.gov.br/wpcontent/uploads/2014/12/DD-256-2016-E-Valores-Orientadores-Dioxinas-e Furanos2016-Intranet.pdf>. São Paulo: 2016. Acesso em: 08 out.2018.

CL:AIRE- Contaminated Land: Applications in Real Environments. Who we are. London, 2019. Disponível em: <https://www.claire.co.uk/home/about-us>. Acesso em 28 nov. 2019.

CÔRTES, P. L; ALVES FILHO, A. P; RUIZ, M. S; TEIXEIRA, C. E. A deposição de resíduos industriais organoclorados no litoral do Estado de São Paulo: um estudo de caso. Revista de Administração e Inovação, v.8, n.2, p.132-163, 2011.

CUNHA, R. C. A. Avaliação de risco em áreas contaminadas por fontes industriais desativadas- estudo de caso. 1997. 165f. Tese (Doutorado em Geociências)- Instituto de Geociências da Universidade de São Paulo, USP, São Paulo, 1997.

EEA- Europen Environment Agency- Progress in management of contaminated sites. Copenhagen, 2014. Disponível em: <https://www.eea.europa.eu/data-andmaps/indicators/progress-in-management-of-contaminated-sites-3/assessment $>$. Acesso em: 20 ago. 2020.

European Soil Data Centre (ESDAC). Disponível em: <https://esdac.jrc.ec.europa.eu/>. Nov. 2019. Acesso em: 27. nov. 2019. 
ENTERPA Engenharia e Pesquisas Tecnológicas S. A. Instrumentação Aterro Sanitário Jacuí. Out. 1996. 6fls.

EUGRIS: portal for soil and water management in Europe. CABERNET Concerted Action on Brownfield and Economic Regeneration Network. 2006. Disponível em: <http://www.eugris.info/displayproject.asp?Projectid=4415>. Acesso em 03. fev. 2019.

EXPO 1998- Exposição Mundial de Lisboa de 1998. Parque EXPO'98 S.A. Lisboa, 1998. 377p.

FOLHA DE SÃO PAULO- Radial Leste ganhará 3.000 árvores até o fim de agosto. São Paulo, julho. $1995 . \quad$ Disponível em: <https://www1.folha.uol.com.br/fsp/1995/7/17/cotidiano>. Acesso em: 01. abril. 2019.

FOSTER, S; HIRATA, R; GOMES, D; D’ELIA, M; PARIS, M. Proteção da Qualidade da Água Subterrânea: um guia para empresas de abastecimento de água, órgãos municipais e agências ambientais. Banco Mundial, Washington, D.C. 2006.

FUNDAÇÃO SEADE- Perfil dos Municípios Paulistas. São Paulo, 2019. Disponível em: <https://perfil.seade.gov.br/\#>. Acesso em: 11 abril. 2019.

GEOINTEGRA Engenharia Ambiental. Projeto Técnico de Reparação de Dano Ambiental. TAC- Termo de Ajustamento de Conduta. Processo Administrativo $\mathrm{n}^{\mathbf{o}} 2011$ 0.0.19.732-6. Serviços Ambientais na área do Aterro Jacuí, Vila Jacuí, São Paulo/SP. Fase II. Plano de Intervenção e Análise de Risco à Saúde Humana. Dez. 2016. p.12-34.

. Serviços Ambientais na área do Aterro Jacuí, Vila Jacuí, São Paulo/SP. Fase I. vol. 2. mar. 2013. 347f.

Serviços Ambientais na área do Aterro Jacuí, Vila Jacuí, São Paulo/SP. Informações Complementares da Fase I. Atendimento ao PT n ${ }^{\circ}$ 068/GTAC/2014. abr. 2014.

GIL, A. C. Como elaborar projetos de pesquisa. 4 ed. São Paulo: Atlas, 2002.

GIL, A. C. Métodos e Técnicas de Pesquisa Social. 5 ed. São Paulo: Altas, 2007.

GOUVEIA, N; PRADO, R. R. Riscos à saúde em áreas próximas a aterros de resíduos sólidos urbanos. Revista Saúde Pública, v.44, n.5, p.859-866. 2010.

GRIMSKI, D. Revitalização de áreas degradadas e contaminadas na Alemanha e na Europa. In: MOERI, E; COELHO, R; MARKER, A. Remediação e Revitalização de áreas contaminadas. São Paulo: Signus Editora, 2004. p. 3-15.

GÜNTHER, W. M. R. Áreas Contaminadas no contexto da Gestão Urbana. Revista São Paulo em Perspectiva, São Paulo, v.20, n.2, p. 105-117, abr./jun. 2006. 
Áreas contaminadas por resíduos industriais perigosos e usos posteriores à desinstalação industrial: algumas questões de saúde pública. In: XXVIII Congreso Interamericano de Ingeniería Sanitaria Y Ambiental. Cancun- México, v. 28, p. 1-5, out. 2002.

HABERMANN, M; GOUVEIA, N. Requalificação urbana em áreas contaminadas na cidade de São Paulo. Estudos Avançados, v. 28, n. 82, p. 129-137, 2014.

HARIK, P; TAYLOR, M; WELLE, B. From Dumps to Destinations: The Conversion of Landfi lls to Parks. The Trust for Public Land, Wasington. 2006.

IBGE- Instituto Brasileiro de Geografia e Estatística. Estatísticas-Cidades: Panorama São Paulo. 2017. Disponível em: <https://cidades.ibge.gov.br/brasil/sp/saopaulo/panorama>. Acesso em: 20 ago. 2018.

IPT- Instituto de Pesquisas Tecnológicas do Estado de São Paulo. A produção imobiliária e a reabilitação de áreas contaminadas: contratação de serviços, responsabilidade legais e viabilidade de empreendimentos. MANNA, E. D; ARAÚJO, M. M; JUNIOR, R. F. M (Org). São Paulo: SECOVI- SP, 2018.

JACOBI, P. R. Espaços píblicos e práticas participativas na gestão do meio ambiente no Brasil. Sociedade e Estado, Brasília, v. 18, n. 1/2, p. 315-338, jan/dez. 2003.

JACOBI, P. R; BESEN, G. R. Gestão de resíduos sólidos em São Paulo: desafios da sustentabilidade. Estudos Avançados, São Paulo, v.25, n.71, p. 135-158. 2011.

JORNAL DA USP- Urbanismo: Arquitetura, Luz, Espaço, Matéria. N.748, ano XXI. 12 a 18 de dezembro. 2005. p. 1-5.

LEITE, T. M C. Entraves espaciais: Brownfields caracterizados por aterros de resíduos sólidos urbanos desativados no município de São Paulo/SP. 2005. 146f. Tese (Doutorado em Geografia) - Instituto de Geociências e Ciências Exatas da Universidade Estadual Paulista, UNESP, Rio Claro, 2005.

LEMOS, M. M. G. Atributos e vulnerabilidade dos solos sob a perspectiva ambiental e critérios da qualidade do solo e da água subterrânea. Caderno de ConhecimentoPrevenção e Controle da Poluição do Solo e das Águas Subterrâneas. Companhia Ambiental do Estado de São Paulo- CETESB. São Paulo. Agosto, 2019. p. 43-85.

LIMPURB/SSO. Departamento de Limpeza Urbana/ Secretaria de Serviços de Obras. Projeto do Aterro Sanitário do Jacuí. Ofício no 264/Limpurb/83. Nov. 1983. 1 fl.

LINO, J. S; AQUINO, A. R. Proposta de classificação de brownfields. Ciência \& Tecnologia, Rio Claro, v.1, n.1-2, p. 1-23. 2017.

LOCATELLI, M. M; ARANTES, B. L; POLIZEL, J. L; FILHO, D. F. S; FRANCO, M. A. R. O panorama atual da cobertura arbórea da cidade de São Paulo. Revista Labverde, v. 9, n.1, São Paulo, p. 29-48. 2018. 
MAIA, B. S; FERREIRA, D. G; PAULA, G. F; SANTANA, H. C. Influência das áreas verdes a qualidade de vida nos centros urbanos: Estudo em Governador Valadares/MG. Anais do XV Congresso Nacional do Meio Ambiente- Poços de Caldas. Espaço Cultura da Urca. Poços de Caldas, Minas Gerais, p. 440-445. 2018.

MARCONI, M. A; LAKATOS, E. M. Fundamentos de metodologia científica. 6 ed. São Paulo: Altas, 2008.

MARKER, A. Manual: Revitalização de áreas degradadas e contaminadas (brownfields) na América Latina. ICLEI-Brasil. Departamento de Proteção Ambiental da Cidade de Stuttgart, Alemanha. $1^{\circ}$ ed. São Paulo, 2013.

MAXIMIANO, A. M. S; MORAES, S. L; TEIXEIRA, C. E. Etapas do Gerenciamento de Áreas Contaminadas- GAC. In: MORAES, S. L; TEIXEIRA, C. E; MAXIMIANO, A. M. $\mathrm{S}(\mathrm{Org})$. Guia de elaboração de planos de intervenção para o gerenciamento de áreas contaminadas. 1 ed. São Paulo: IPT e BNDES, 2014. p. 27-33.

MMA- Ministério do Meio Ambiente. Cidades Sustentáveis: Áreas Contaminadas. Disponível em: <https://www.mma.gov.br/cidadessustentaveis/areascontaminadas>. Brasília, 2019. Acesso em: 05 de julho 2019.

- Curso de Capacitação de Capacitação: Sustentabilidade na Administração Pública. Brasília. Solar: agosto, 2013. 98p.

Plano Municipal Simplificado de Gestão Integrada de Resíduos Sólidos. 3 ed. Brasília, 2016.

MORAES, L. R. S; BORJA, P. C. Gestão integrada e sustentável novo paradigma para os resíduos sólidos urbanos no Brasil e na Bahia. Revista do Instituto Politécnico da Bahia, n. 21, p.16-21. Mar. 2015.

MORINAGA, C. M. Áreas contaminadas e a construção da paisagem pós-industrial na cidade de São Paulo. 2013. 201 f. Tese (Doutorado - Área de Concentração: Paisagem e Ambiente) - Faculdade de Arquitetura e Urbanismo, Universidade de São Paulo, São Paulo. 2013.

. Gestão das paisagens na recuperação de áreas contaminadas. In: PELLEGRINO, P; MOURA, N. B (Orgs.). Estratégias para uma infraestrutura verde. Barueri- São Paulo: Manole, 2017. p. 243-260.

Recuperação de áreas contaminadas: um novo desafio para projetos paisagísticos. 2007. 152 f. Dissertação (Mestrado - Área de Concentração: Paisagem e Ambiente) - Faculdade de Arquitetura e Urbanismo, Universidade de São Paulo, FAU/USP, São Paulo. 2007.

MPSP- Ministério Público do Estado de São Paulo. Cria Grupo de Trabalho para análise e fixação de premissas relativas à valoração de dano ambiental. Ato No036/2011-PG, 06 de maio de 2011. Diário Oficial da Cidade de São Paulo, de maio de 2011. Poder Executivo, São Paulo, SP, 07 de maio de 2011. Seção I, p.50. 
Estado de São Paulo. Ação Civil Pública. Autos nº1177/053.00.018822-6. São Paulo, set. 2006. 4fls.

Prefeitura do Município de São Paulo. Ação Civil Pública Nº00479303.2012.8.26.0053. Poder Judiciário. 2 $2^{\mathrm{a}}$ Vara da Fazenda Pública. São Paulo, fev. 2012. $11 \mathrm{fls}$.

NEWLANDS- New Life. New Environments. New Partnerships. 2019. Disponível em: <http://www.newlandsproject.co.uk/>. Acesso em: 28 nov. 2019.

OECD- Organisation for Economic Co-operation and Development. Where: Global reach. 2019. Disponível em: <http://www.oecd.org/about/members-and-partners/>. Acesso em: 02. Jul. 2019.

ONU- Organização das Nações Unidas. Objetivos de Desenvolvimento Sustentável. Outubro, 2015. p. 1-49. Disponível em: 〈https://sustainabledevelopment.un.org>. Acesso em: 01. Jun. 2019.

PEDRO, A. F. P. Direito Ambiental Aplicado. In: PHILIPPI JR, A; ROMÉRO, M. A; BRUNA, G. C (eds). Curso de Gestão Ambiental. v.13, 2 ed. Barueri, São Paulo: Manole, 2014. p. 651-705.

PGIRS- Plano de Gestão Integrada de Resíduos Sólidos da Cidade de São Paulo. Prefeitura de São Paulo e Serviços. Resumo Executivo, São Paulo. 2014. Disponívelem: $<$ https://www.prefeitura.sp.gov.br/cidade/secretarias/regionais/amlurb/notic ias/?p=169047>. Acesso em 10 ago. 2018.

PNSB- Pesquisa Nacional de Saneamento Básico 2008. IBGE/Ministério de Planejamento, Orçamento e Gestão. Rio de Janeiro, 2010. p.219.

POLZER, V. O Desafio das cidades: Aterro Sanitário x Incinerador com geração de energia (WTE). Revista GeoTemas, Rio Grande do Sul, v 3, n. 2(3), p. 3-19, jul./dez., 2013.

PORTELLA, M. O; RIBEIRO, J. C. J. Aterros sanitários: aspectos gerais e destino final dos resíduos. Revista Direito Ambiental e Sociedade, v. 4, n. 1, p. 115-134. 2014.

RAMIRES, J. Z.S; VITOR, J. D. S. O impacto ambiental oriundo do descarte irregular de resíduos: a contaminação do solo e das águas subterrâneas no município de São Paulo. Anais do XVI Congresso Brasileiro de Águas Subterrâneas. Encontro Nacional de Perfuradores de Poços. São Luís, Maranhão, p.1-17. 2010.

RIO 1992- Declaração do Rio de Janeiro. A Conferência das Nações Unidas sobre meio ambiente e desenvolvimento, de 3 a 14 de junho de 1992. Reafirmando a Declaração da Conferência das Nações Unidas sobre o Meio Ambiente Humano, adotada em Estocolmo em 16 de junho de 1972. Estudos Avançados, v.6, n.15, p. 153-159. 1992. 
ROCCA, A. C. C. Fonte de Poluição do Solo e das águas subterrâneas. Caderno de Conhecimento- Prevenção e Controle da Poluição do Solo e das Águas Subterrâneas. Companhia Ambiental do Estado de São Paulo- CETESB. São Paulo. Agosto, 2019. p. 942.

ROSA, B. P; PAULA, B. C. L; COLEONE, E. S. A; CAMPOS, F. Impactos causados em cursos d'água por aterros controlados desativados no Município de São Paulo, Sudeste do Brasil. Revista Brasileira de Gestão Ambiental e Sustentabilidade. São Paulo, v.4, n.7, p. 63-76. 2017.

SAMADDER, S. R; PRABHAKAR, R; KHAN, D; KISHAN, D; CHAUHAN, M. S. Analysis of the contaminants released from municipal solid waste landfill site: A case study. Science of the Total Environment, India, p.593-601. Dec. 2017.

SANCHES, P. M. De áreas degradadas a espaços vegetados- Potencialidades de áreas vazias, abandonadas e subutilizadas como parte da infraestrutura verde urbana. 2011. 296 f. Dissertação (Mestrado - Área de Concentração: Paisagem e Ambiente). Faculdade de Arquitetura e Urbanismo da Universidade de São Paulo, FAU-USP, São Paulo, 2011. 2014. 279p.

De áreas degradadas a espaços vegetados. São Paulo: Editora Senac São Paulo,

Potencialidades de paisagens degradadas e residuais: o caso de São Bernardo do Campo. In: PELlEGRINO, P; MOURA, N. B (Orgs.). Estratégias para uma infraestrutura verde. Barueri- São Paulo: Manole, 2017. p. 147-181.

SÁNCHEZ, L. E. Avaliação de Impacto Ambiental: conceitos e métodos. 1 ed. São Paulo: Oficina de textos, 2006.

Desengenharia: o passivo ambiental na desativação de empreendimentos industriais. São Paulo: Editora da Universidade de São Paulo-EDUSP, 2001.

Revitalização de Áreas Contaminadas. In: MOERI, E; COELHO, R; MARKER, A. Remediação e Revitalização de áreas contaminadas. São Paulo: Signus Editora, 2004. p. 79-90.

SANTOS, T. B; NASCIMENTO, A. P. N; REGIS, M. M. Áreas verdes e qualidade de vida: uso e percepção ambiental de um parque urbano na cidade de São Paulo, Brasil. Rev. Gest. Ambient. Sustentabilidade-GeAS, V.8 N.2, 363-388. 2019.

SÃO PAULO (cidade). Lei N. 15.098, de 05 de janeiro de 2010. Obriga o Poder Executivo Municipal a publicar na Imprensa Oficial ou disponibilizar no site oficial da Prefeitura Relatório das Áreas Contaminadas do Município de São Paulo. Diário Oficial da Cidade de São Paulo, de 05 de janeiro de 2010. Poder Executivo, São Paulo, SP, 06 de janeiro de 2010. Seção I, p.1. 
. Lei N. 51.436, de 26 de abril de 2010. Regulamenta a Lei $N^{\circ} 15.098$, de 5 de abril de janeiro de 2010, que obriga o poder executivo a publicar na imprensa oficial ou disponibilizar no site oficial da prefeitura relatório das áreas contaminadas do município de São Paulo. Diário Oficial da Cidade de São Paulo, de 26 de abril de 2010. Poder Executivo, São Paulo, SP, 27 de abril de 2010a. Seção I, p.1.

Lei N. 16.402, de 22 de março de 2016. Disciplina o parcelamento, o uso e a ocupação do solo no Município de São Paulo, de acordo com a Lei no 16.050, de 31 de julho de 2014 - Plano Diretor Estratégico (PDE). Diário Oficial da Cidade de São Paulo, de 22 de março de 2010. Poder Executivo, São Paulo, SP, 23 de março de 2010. Seção I, n.54. p.1.

. Lei $n^{\circ} 13.308$, de 31 de janeiro de 2002. Cria o Parque Municipal Jardim Primavera na área ocupada pelo Aterro Sanitário do Jacuí e dá outras providências. Diário oficial do Munícipio de São Paulo de 31 de janeiro de 2002, São Paulo, SP,31 de janeiro de 2002. Seção I, p.1.

Lei $\mathrm{N}^{\mathrm{o}}$ 14.186, de 4 de julho de 2006. Institui o Programa Municipal de Arborização Urbana, e dá outras providências. Diário Oficial da Cidade de São Paulo, de 5 de julho de 2006. Poder Executivo, São Paulo, SP, 05 de julho de 2006. Seção I, p. 1.

Lei $N^{\circ} 16.050$, de 31 de julho de 2014. Aprova a Política de Desenvolvimento Urbano e o Plano Diretor Estratégico do Município de São Paulo e revoga a Lei $\mathrm{n}^{\circ}$ 13.430/2002. Diário Oficial da Cidade de São Paulo, de 01 de agosto de 2014. Poder Executivo, São Paulo, SP, 01 de agosto de 2014. Seção I, p.1.

SÃO PAULO (Estado). Lei N. 28.335, de 15 de julho de 1988. Declara de utilidade pública para fins de desapropriação, imóvel situado nesta Capital, necessário à implantação de Parque de Lazer, Cultura e Esporte da Região Metropolitana de São Paulo. Diário Oficial do Estado de São Paulo de 15 de julho de 1988. Poder Executivo, São Paulo, SP, 16 de julho de 1988. Seção I, p. 1.

. Lei N. 997, de 31 de maio de 1976. Dispõe sobre o Controle da Poluição do Meio Ambiente. Diário Oficial do Estado de São Paulo de 31 de maio de 1976. Poder Executivo, São Paulo, SP, 01 de junho de 1976. Seção I, p.1.

Lei N.9.509, de 20 de março de 1997. Dispõe sobre a Política Estadual do Meio Ambiente, seus fins e mecanismos de formulação e aplicação. Diário Oficial do Estado de São Paulo, de 20 de março de 1997. Poder Executivo, São Paulo, SP, 21 de março de 1997. Seção I, p. 1.

Lei $\mathrm{n}^{\mathrm{o}} 13.577$, de 8 de julho de 2009. Dispõe sobre diretrizes e procedimentos para a proteção da qualidade do solo e gerenciamento de áreas contaminadas, e dá outras providências correlatas. Diário Oficial do Estado de São Paulo de 08 de julho de 2009. Poder Executivo, São Paulo, SP, 09 de julho de 2009. Seção I, p. 1. 
Decreto $N^{\circ}$ 59. 263/2013, de 5 de junho de 2013. Regulamenta a Lei $\mathrm{n}^{\mathrm{o}} 13.577$, de 8 de julho de 2009, que dispõe sobre diretrizes e procedimentos para a proteção da qualidade do solo e gerenciamento de áreas contaminadas, e dá providências correlatas. Diário Oficial do Estado de São Paulo de 08 de julho de 2013. Poder Executivo, São Paulo, SP, 09 de julho de 2009. Poder Executivo, Seção I, p.3.

Resolução SMA N. 72, de 13 de setembro de 2012. Altera a composição do Conselho de Orientação do Parque Villa-Lobos, dispõe sobre o cadastramento de entidades da sociedade civil, e a eleição destes representantes para integrarem o Conselho de Orientação do Parque Villa-Lobos. Diário Oficial do Estado de São Paulo, de 13 de setembro de 2012. Poder Executivo, São Paulo, SP, 15 de setembro de 2012. Seção I, p. 30 .

. Resolução SMA No 10, de 08 de fevereiro de 2017. Dispõe sobre a definição das atividades potencialmente geradoras de áreas contaminadas. Diário Oficial do Estado de São Paulo, de 08 de fevereiro de 2017. Poder Executivo, São Paulo, SP, 10 de fevereiro de 2017. Seção I, p. 43.

Resolução SMA N 11, de 08 de fevereiro de 2017. Dispõe sobre a definição das regiões prioritárias para a identificação de áreas contaminadas. Diário Oficial do Estado de São Paulo, de 08 de fevereiro de 2017a. Poder Executivo, São Paulo, SP, 10 de fevereiro de 2017. Seção I, p. 43- 47.

Resolução SMA No 5, de 28 de março de 2001. Dispõe sobre a aplicação e o licenciamento ambiental das fontes de poluição a que se refere a Resolução $\mathrm{n}^{\circ} 273$, de 29 de novembro de 2000, do Conselho Nacional do Meio Ambiente - CONAMA. Diário Oficial do Estado de São Paulo, de 5 de março de 2001. Poder Executivo, São Paulo, SP, 28 de março de 2001. p.34.

Decreto N. 47.400, de 4 de dezembro de 2002. Regulamenta dispositivos da Lei Estadual $\mathrm{n}^{\circ}$ 9.509, de 20 de março de 1997, referentes ao licenciamento ambiental, estabelece prazos de validade para cada modalidade de licenciamento ambiental e condições para sua renovação, estabelece prazo de análise dos requerimentos e licenciamento ambiental, institui procedimento obrigatório de notificação de suspensão ou encerramento de atividade, e o recolhimento de valor referente ao preço de análise. Diário Oficial do Estado de São Paulo, de 04 de dezembro de 2002. Poder Executivo, São Paulo, SP, 05 de dezembro de 2002. Seção I, p. 10.

SEPE, P. M; SILVA, F. A. N. Revitalização de áreas contaminadas no município de São Paulo. In: MOERI, E; COELHO, R; MARKER, A. Remediação e Revitalização de áreas contaminadas. São Paulo: Signus Editora, 2004. p. 43-52.

SHINZATO, P. O impacto da vegetação nos microclimas urbanos. 2009. $173 \mathrm{f}$. Dissertação (Mestrado- Área de Concentração: Tecnologia da Arquitetura). Faculdade de Arquitetura e Urbanismo da Universidade de São Paulo, FAU-USP, São Paulo, 2009.

SILVA, E. C; PELICIONI, M. C. F. Conselhos e Gestão Ambiental Local: Processos Educativos e Participação Social. In: PHILIPPI JR, A; ROMÉRO, M. A; BRUNA, G. C 
(eds). Curso de Gestão Ambiental. v.13, 2 ed. Barueri, São Paulo: Manole, 2014. p. 815830 .

SILVA, T. B. Áreas de Abandono: Análise com base nos fundamentos do desenho ambiental sobre projetos que visam a recuperação de territórios degradados. Revista Labverde, São Paulo, n.4, p.1-27. 2016.

SMDU- Secretaria Municipal de Desenvolvimento Urbano de São Paulo. Caderno de Propostas Planos Regionais das Subprefeituras- Perímetros de ação: São Miguel Paulista. São Paulo, 2016. 54 pag. Disponível em: <http://gestaourbana.prefeitura.sp.gov.br/planosregionais/arquivo>. Acesso em: 20 ago. 2018.

. (Coord.). Caderno de Propostas Planos Regionais das SubprefeiturasQuadro analítico: São Miguel Paulista. São Paulo, dez. 2016a. 18 pag. Disponível em: <http://gestaourbana.prefeitura.sp.gov.br/planosregionais/arquivo>. Acesso em: 20 ago. 2018.

SONG, S. O papel da análise de risco na remediação de áreas contaminadas. In: MOERI, E; COELHO, R; MARKER, A. Remediação e Revitalização de áreas contaminadas. São Paulo: Signus Editora, 2004. p. 65-78.

SOUSA, C. A. The greening of brownfields in America Cities. Jornal of Environment Planning and Management, v.47, n. 4. Jul. 2004.

. Turning brownfields into green space in the City of Toronto. Landscape and Urban Planning, v. 62, p.181-198. Jul. 2003.

SPÍNOLA, A. L. S. Inserção de áreas contaminadas na gestão municipal: desafios e tendências. 2011. 289f. Dissertação (Doutorado- Área de Concentração: Saúde Ambiental). Faculdade de Saúde Pública da Universidade de São Paulo, FSP/USP, São Paulo, 2011.

SPÍNOLA, A. L. S; GLOEDEN, E; PHILIPPI JR, A. Gestão de Áreas Contaminadas. In: PHILIPPI JR, A; ROMÉRO, M. A; BRUNA, G. C (eds). Curso de Gestão Ambiental. 2 ed. Barueri, São Paulo: Manole, 2014. p. 1025-1055.

STUERMER, M. M; BROCANELI, P. F; VIEIRA, M. E. M. Os aterros sanitários desativados e o sistema de áreas verdes da cidade de São Paulo: possibilidade de integração. Revista LABVERDE, São Paulo, n.02, p.11-29, 2011.

SVMA- Secretaria do Verde e do Meio Ambiente- Curso de Licenciamento Ambiental. Gerenciamento de áreas contaminadas no Licenciamento Ambiental. Carolina Afonso Pinto. Grupo Técnico de Áreas Contaminadas- GTAC/SVMA. São Paulo: dez. 2016.

. Gerenciamento de Áreas Contaminadas no município de São Paulo. Shuquair Mahmud Sai; André Luiz Andrade Pinto. Grupo Técnico de áreas Contaminadas-GTAC e Seção Técnica de Crítica e Tombamento-STCT. São Paulo, out. 2016a. 
Áreas Contaminadas. São Paulo. 02. Mai. 2019a. Disponível em: <https://www.prefeitura.sp.gov.br/cidade/secretarias/>. Acesso em: 05 set. 2019.

FEMA- Fundo Especial do Meio Ambiente e Desenvolvimento Sustentável. Disponível em: <https://www.prefeitura.sp.gov.br/cidade/secretarias?p=3299>. São Paulo. 2020. Jun/2020.

SVMA- Secretaria do Verde e do Meio Ambiente. Aterro Jacuí Parque Municipal Jardim Primavera. Informação Técnica Nº 20/GTAC/2017. Processo nº 30.104915. jan. 2017. 4fls.

. Aterro Sanitário de Vila Jacuí. Informação Técnica No 26/GTAC/2012. Ofício 031/12/CLE. fev. 2012. 2fls.

- Implantação do Parque Olímpico Sapopemba. Informação Técnica No 22/DEPLAN/2009. PA. N ${ }^{\circ}$ 2009-0.50.520-2. Junho. 2009. 5 f.

. Termo de Referência para Contratação de Serviços de Avaliação ambiental, na área do antigo Aterro Jacuí. Informação Técnica $N^{\circ} 149 / G T A C / 2012$. Processo $n^{\circ}$ 2012-0.183741-0. Jul. 2012a. 9fls.

TOZZI, D; GEISER, R. De lixão a área de lazer. Natureza Profissional, n.279. p.100140. 2005.

TRIVIÑOS, A. N. S. Introdução à pesquisa em ciências sociais: a pesquisa qualitativa em educação. 1 ed. São Paulo: Altas, 1987.

USEPA- United States Environmental Protection Agency. Superfund: CERCLA. USA, dez. Disponível em: <https://www.epa.gov/superfund/superfund-cercla-overview>. 2018a. Acesso em: 02 fev. 2019.

. Land Revitalization. USA, dez. Disponível em: <https://www.epa.gov/landrevitalization>. 2018b. Acesso em: 02 fev. 2019.

Basic Information about Land Revitalization. USA, dez. Disponível em: <https://www.epa.gov/land-revitalization/basic-information-about-land-revitalization>.

2018c. Acesso em: 02 fev. 2019.

. Superfund Success Stories: EPA Region 2-Brick Township Landfill. USA, jun. Disponível em: <https://www.epa.gov/superfund/superfund-success-stories-epa-region2>. 2018d. Acesso em 06 fev. 2019.

Brick Township landfill- Brick Township, NJ. USA, out. Disponível em: $<$ https://cumulis.epa.gov/supercpad/SiteProfiles/index.cfm?fuseaction=second.Cleanup\&i $\mathrm{d}=0200540 \#$ bkground $>$. 2018e. Acesso em 06 fev. 2019.

Reducing Wasted Food At Home. USA, Agosto. 2017. Disponível em: <https://www.epa.gov/recycle/reducing-wasted-food-home\#ther>. Acesso em: 02. Jul. 2019. 
Resource Conservation and Recovery Act (RCRA) Laws and Regulations. USA. 2019. Disponível em: <https://www.epa.gov/rcra/resource-conservation-andrecovery-act-rcra-regulations\#nonhaz>. Fev. Acesso em: 01/06/2019.

Superfund Site: Love Canal Niagara Falls, NY. 2018. Disponível em: <https://cumulis.epa.gov/supercpad/SiteProfiles/index.cf>. Acesso em: 20. Jul. 2018.

VALENTIM, L. S. O. Requalificação urbana em áreas de risco à saúde devido à contaminação do solo por substâncias perigosas: um estudo de caso na cidade de São Paulo. 2005. 158f. Dissertação (Mestrado) - Faculdade de Arquitetura e Urbanismo, Universidade de São Paulo, USP, São Paulo, 2005.

VARGAS, H. C. Gestão de Áreas Urbanas Deterioradas. In: PHILIPPI JR, A; ROMÉRO, M. A; BRUnA, G. C (Eds). Curso de Gestão Ambiental. 2 ed. Barueri, São Paulo: Manole, 2014. P.993-1024.

WASTE ATLAS- The World's 50 Biggest Dumpsites. University of Leeds. UK. 2014. $120 \mathrm{p}$.

WB- WORLD BANK GROUP. What a Waste 2.0: A Global Snapshot of Solid Waste Management to 2050. Washington, DC. 2018. Disponível em: <https://www.worldbank.org/en/news/immersive-story/2018/09/20/what-a-waste>. p.272.

WEBER AMBIENTAL LTDA. Relatório de Avaliação Ambiental e Análise de RiscoTier 2- Fase 2. Projeto $n^{\circ}$ 01.257.07. Antigo Aterro Municipal Jacuí. Nov. 2007. 59f.

. Relatório de Avaliação Ambiental e Análise de Risco- Tier 2- fase 2. Projeto $\mathrm{n}^{\circ}$ 01.257.07. Antigo Aterro Municipal Jacuí. Abr. 2008. 102f.

Relatório Técnico: Investigação Complementar de Contaminação do Solo e Água Subterrânea do Parque Villa-Lobos. Processo No 6.204/2011. Junho. 2013. 2179 fls.

WERNSTEDT, K; BLACKMAN, A; LYON, T. P; NOVAK, K. Revitalizing underperforming and contaminated land through voluntary action: Perspectives from U.S voluntary cleanup programs. Land Use Policy, U.S, v.31, p.545-556. 2013.

WORLDWATCH INSTITUTE. Global municipal solid waste continues to grow. 24. July. 2012. Washington, DC. Disponível em: <http://www.worldwatch.org/globalmunicipal-solid-waste-continues-grow-0>. Acesso em: 02. Jul. 2019.

YIN, R. K. Estudo de caso: planejamento e métodos. 4ed. Porto Alegre: Bookman, 2010.

ZHANG, L; KLENOSKY, D. B. Residents' perceptions and attitudes toward waste treatment facility sites and their possible conversion: A literature review. Urban Forestry \& Urban Greening, U.S, v.20, p.32-42. 2016. 